\title{
U.S. Geological Survey Sagebrush Ecosystem Research Annual Report for 2020
}

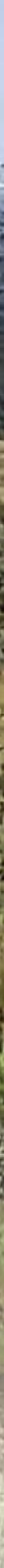


Cover. Sagebrush landscape in central Utah. Photograph by Steven Hanser, U.S. Geological Survey. 


\section{U.S. Geological Survey Sagebrush Ecosystem Research Annual Report for 2020}

Edited by Steven E. Hanser and Lief A. Wiechman

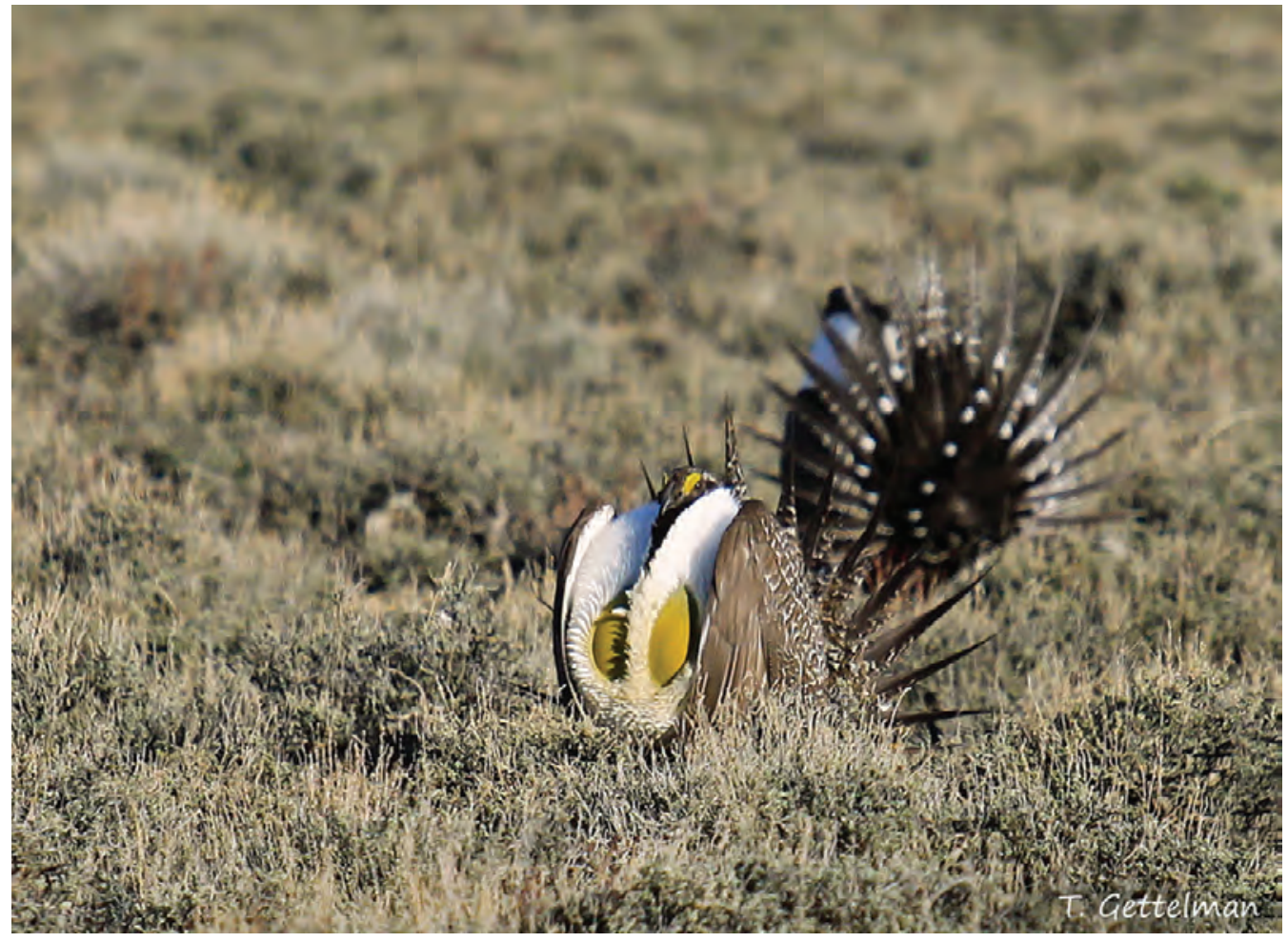

Greater sage-grouse displaying yellow air sacks. Photograph by Tatiana Gettelman, U.S. Geological Survey.

Circular 1470 


\title{
U.S. Department of the Interior \\ DAVID BERNHARDT, Secretary
}

\author{
U.S. Geological Survey \\ James F. Reilly II, Director
}

U.S. Geological Survey, Reston, Virginia: 2020

For more information on the USGS - the Federal source for science about the Earth, its natural and living resources, natural hazards, and the environment-visit https://www.usgs.gov or call 1-888-ASK-USGS.

For an overview of USGS information products, including maps, imagery, and publications,

visit https://store.usgs.gov.

Any use of trade, firm, or product names is for descriptive purposes only and does not imply endorsement by the U.S. Government.

Although this information product, for the most part, is in the public domain, it also may contain copyrighted materials as noted in the text. Permission to reproduce copyrighted items must be secured from the copyright owner.

Suggested citation:

Hanser, S.E., and Wiechman, L.A., eds., 2020, U.S. Geological Survey sagebrush ecosystem research annual report for 2020: U.S. Geological Survey Circular 1470, 94 p., https://doi.org/10.3133/cir1470.

ISSN 2330-5703 (online) 


\section{Contents}

Research To Support the Management of the Sagebrush Ecosystem.............................................1

Structure of the U.S. Geological Survey Sage-Grouse and Sagebrush Ecosystem Research

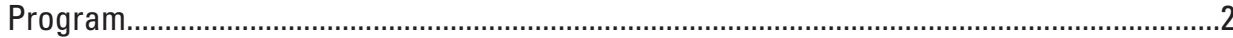

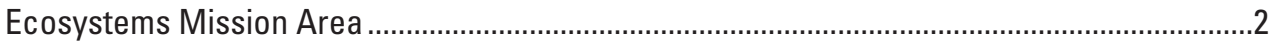

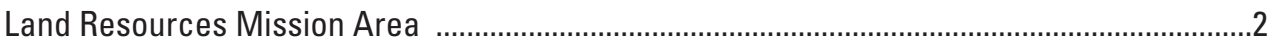

Energy and Minerals Mission Area ……............................................................................

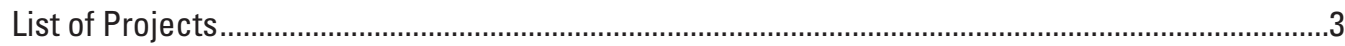

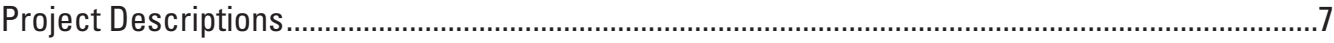

Fire 7

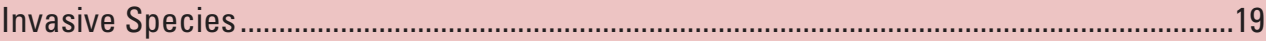

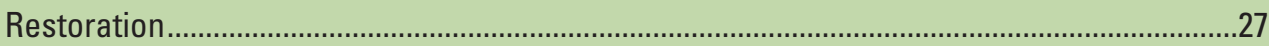

Sagebrush, Sage-Grouse, and Other Sagebrush-Associated Species..................................43

Weather and Climate

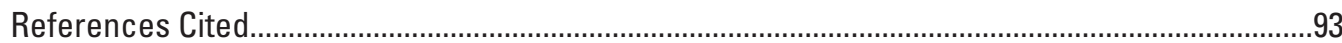

\section{Figures}

1. Location of the sagebrush ecosystem, distribution of greater and Gunnison sage-grouse, and the current sagebrush extent in the Western United States................1

2. Photographs of Blacktail Ridge in northeastern Utah showing the areas of rangeland where juniper has been removed

3. An example of image processing used to reveal information about vegetation type and structure

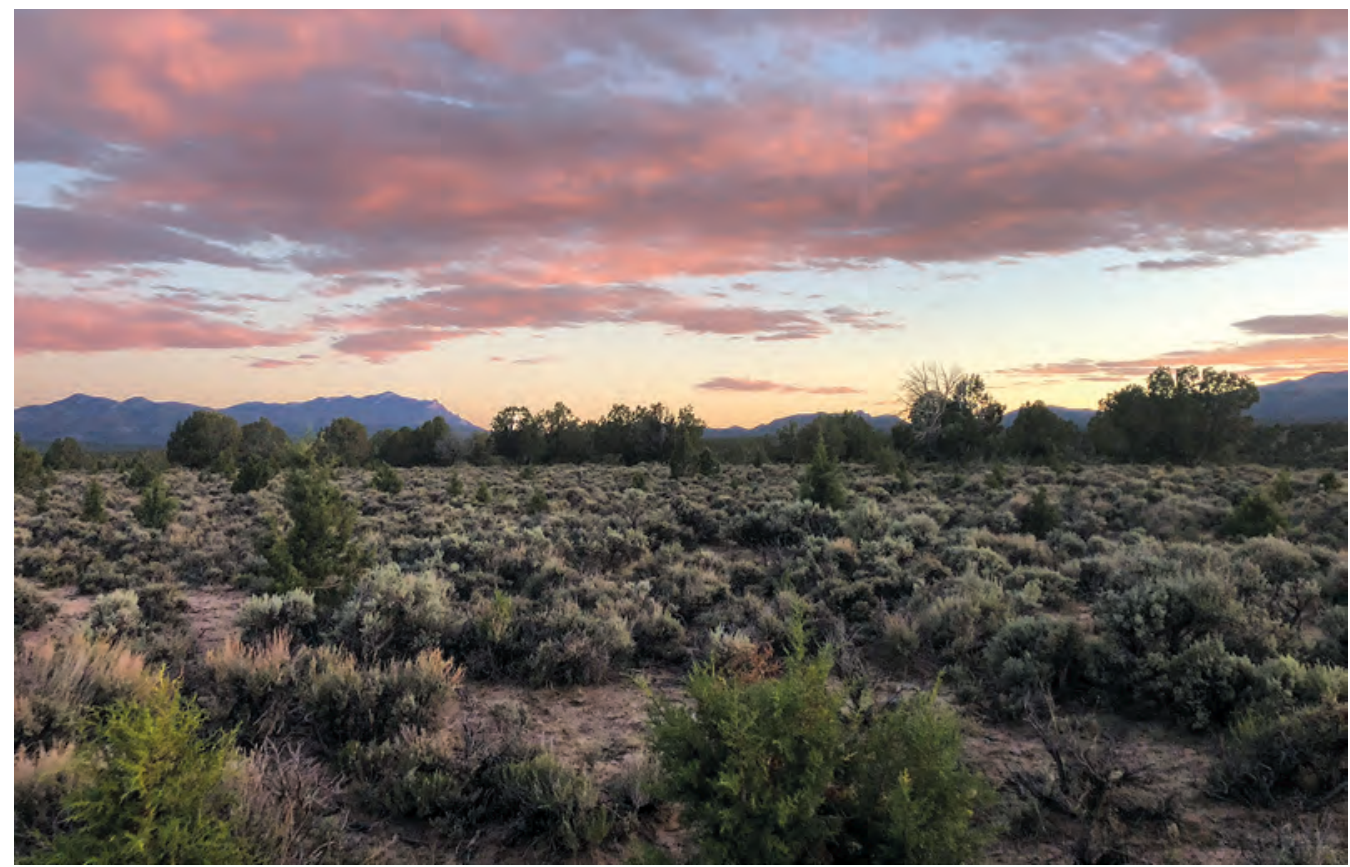

Sagebrush in the Great Basin. Photograph by Sasha Reed, U.S. Geological Survey. 


\section{Conversion Factors}

U.S. customary units to International System of Units

\begin{tabular}{|c|c|c|}
\hline Multiply & By & To obtain \\
\hline \multicolumn{3}{|c|}{ Length } \\
\hline foot $(\mathrm{ft})$ & 0.3048 & meter $(\mathrm{m})$ \\
\hline mile (mi) & 1.609 & kilometer $(\mathrm{km})$ \\
\hline yard (yd) & 0.9144 & meter $(\mathrm{m})$ \\
\hline \multicolumn{3}{|c|}{ Area } \\
\hline acre & 4,047 & square meter $\left(\mathrm{m}^{2}\right)$ \\
\hline acre & 0.4047 & hectare (ha) \\
\hline acre & 0.4047 & square hectometer $\left(\mathrm{hm}^{2}\right)$ \\
\hline acre & 0.004047 & square kilometer $\left(\mathrm{km}^{2}\right)$ \\
\hline
\end{tabular}

International System of Units to U.S. customary units

\begin{tabular}{lcl}
\hline \multicolumn{1}{c}{ Multiply } & By & To obtain \\
\hline meter $(\mathrm{m})$ & Length & foot (ft) \\
kilometer $(\mathrm{km})$ & 3.281 & mile (mi) \\
meter $(\mathrm{m})$ & 0.6214 & yard (yd) \\
\hline & 1.094 & \\
\hline square meter $\left(\mathrm{m}^{2}\right)$ & Area & acre \\
hectare (ha) & 0.0002471 & acre \\
square hectometer $\left(\mathrm{hm}^{2}\right)$ & 2.471 & acre \\
square kilometer $\left(\mathrm{km}^{2}\right)$ & 2.471 & acre \\
\hline
\end{tabular}




\section{Abbreviations}

\begin{tabular}{|c|c|c|c|}
\hline AIM & Assessment, Inventory, and & LTDL & Land Treatment Digital Library \\
\hline & Monitoring & NAIP & National Agriculture Imagery \\
\hline BLM & Bureau of Land Management & & Program \\
\hline CSTG & $\begin{array}{l}\text { Columbian sharp-tailed } \\
\text { grouse }\end{array}$ & NLCD & $\begin{array}{l}\text { National Land Cover } \\
\text { Database }\end{array}$ \\
\hline CSU & Colorado State University & NRCS & Natural Resources \\
\hline DART & disturbance automated & & Conservation Service \\
\hline & reference toolset & PAC & Priority Area for Conservation \\
\hline DDCT & Density and Disturbance & PSM & plant secondary metabolites \\
\hline & Calculation Tool & PVA & population viability analysis \\
\hline DOI & $\begin{array}{l}\text { U.S. Department of the } \\
\text { Interior }\end{array}$ & SageSTEP & $\begin{array}{l}\text { Sagebrush Steppe Treatment } \\
\text { Evaluation Project }\end{array}$ \\
\hline DPS & distinct population segment & SNP & single-nucleotide \\
\hline DRG & Disturbance Response Group & & polymorphism \\
\hline FIAT & Fire and Invasives & STM & state-and-transition model \\
\hline & Assessment Tool & UAS & unmanned aerial systems \\
\hline FWS & U.S. Fish and Wildlife Service & USDA & U.S. Department of \\
\hline GIS & geographic information & & Agriculture \\
\hline & system & USGS & U.S. Geological Survey \\
\hline GPS & Global Positioning System & VHF & very high frequency \\
\hline $\mathrm{HAF}$ & $\begin{array}{l}\text { Habitat Assessment } \\
\text { Framework }\end{array}$ & WGA & $\begin{array}{l}\text { Western Governors } \\
\text { Association }\end{array}$ \\
\hline IMBCR & $\begin{array}{l}\text { Integrated Monitoring in Bird } \\
\text { Conservation Regions }\end{array}$ & WSB & weed-suppressive bacteria \\
\hline PM & integrated population model & WY & Wyoming \\
\hline
\end{tabular}




\section{ate te andits}

$x^{2}+x^{2}+40$

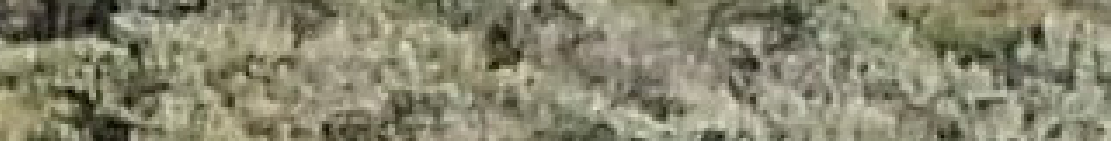

H.

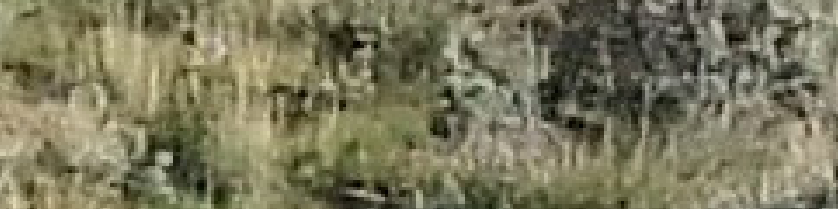

(i)

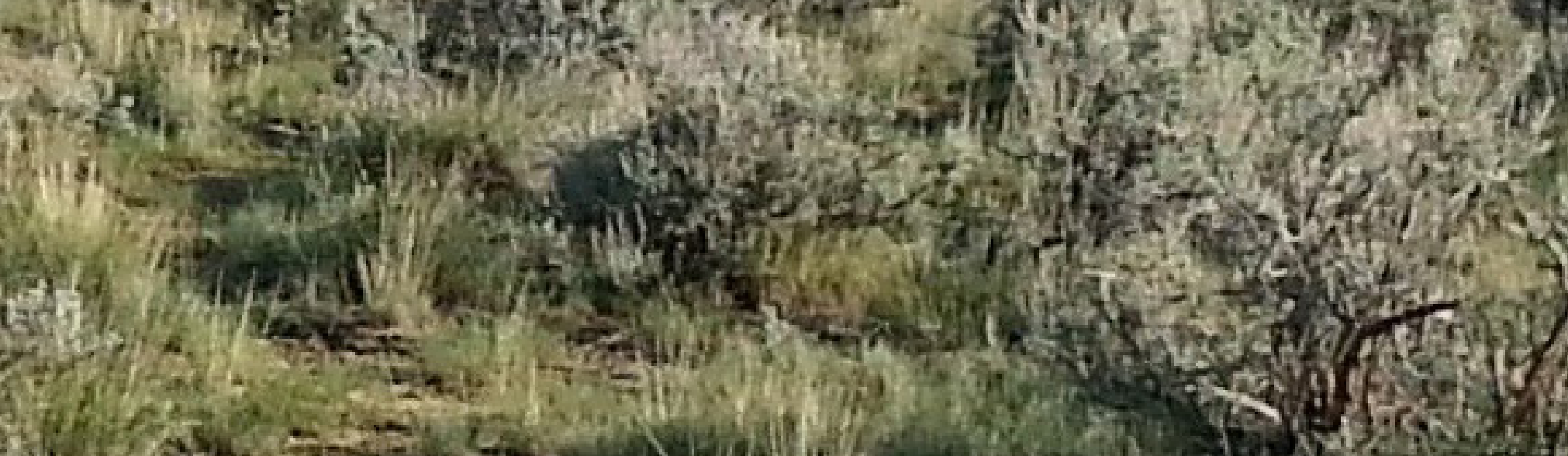
Q

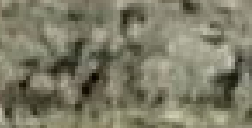

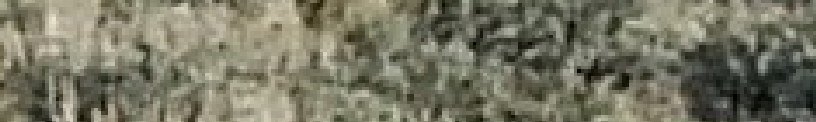

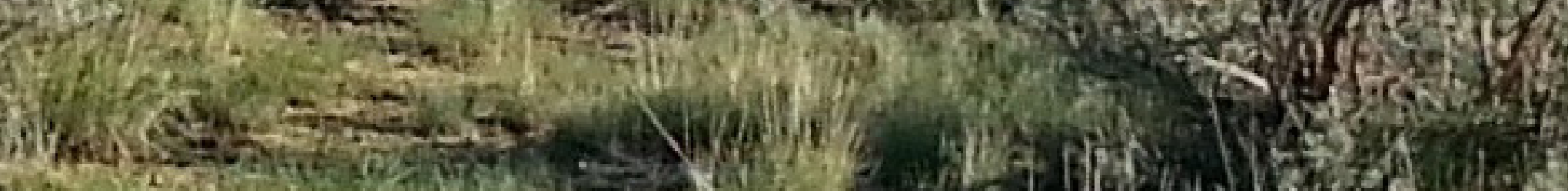
Wing: ert. (6)

Whis

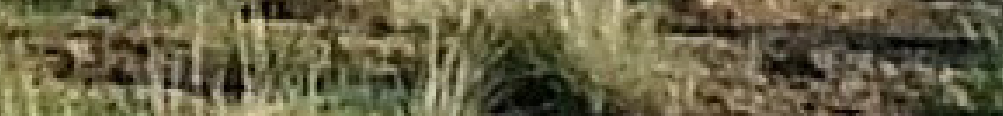

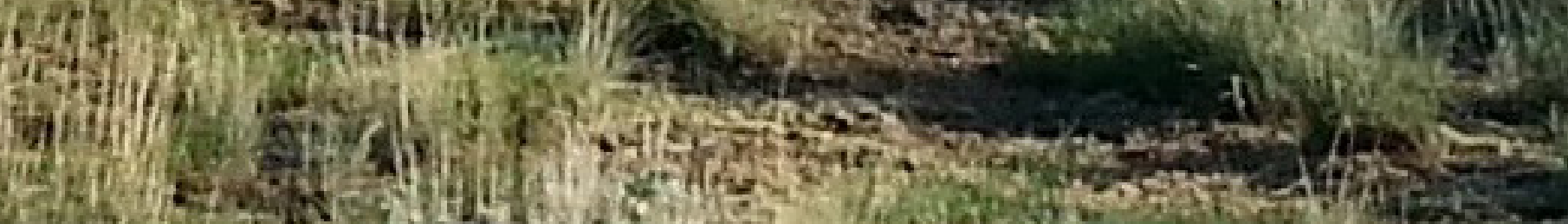

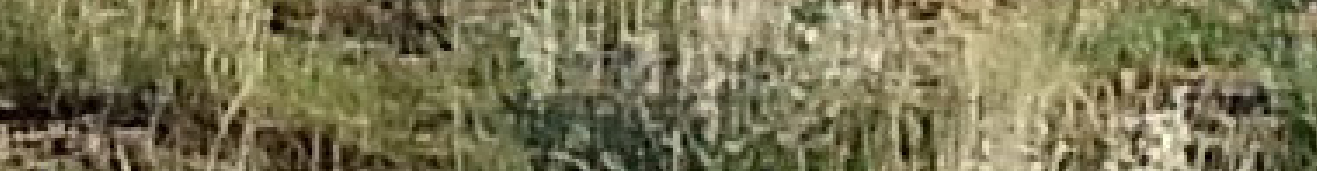

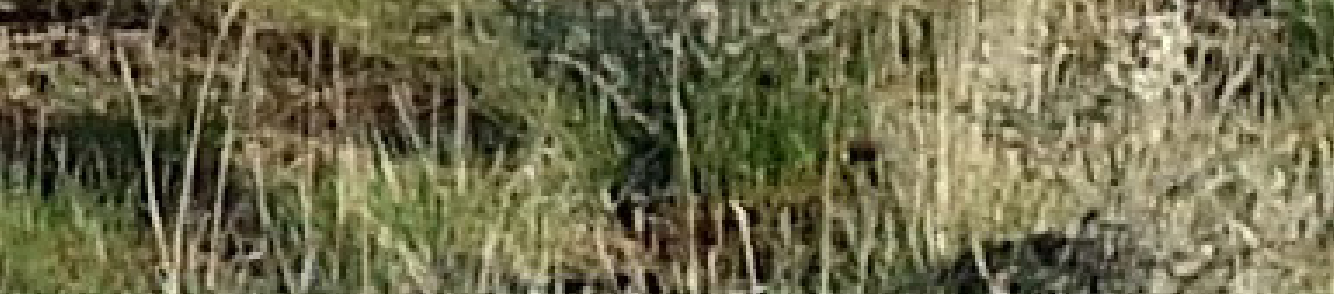
ing (s) Bite? कहैं
Sisto
toing

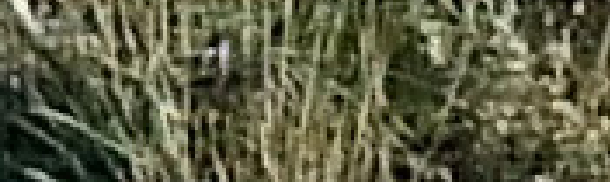

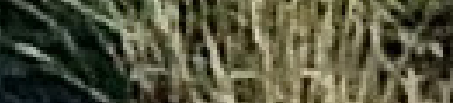

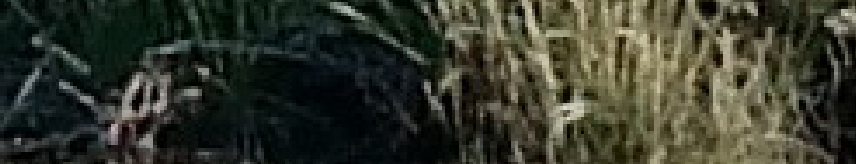

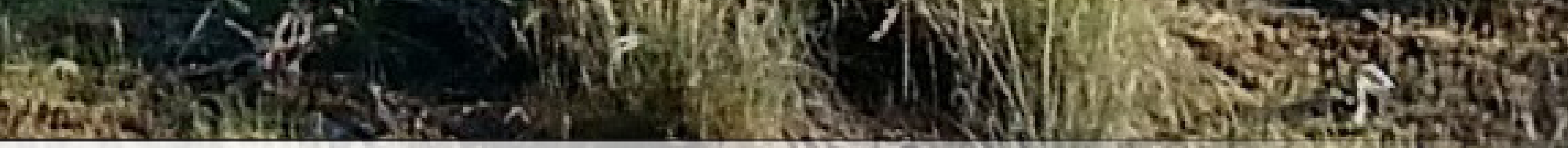
20.

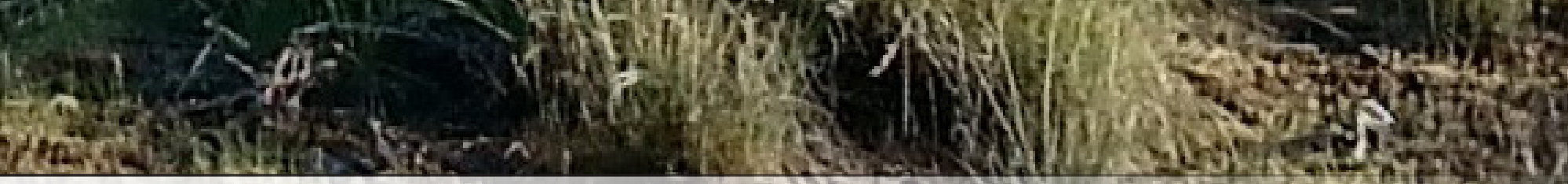

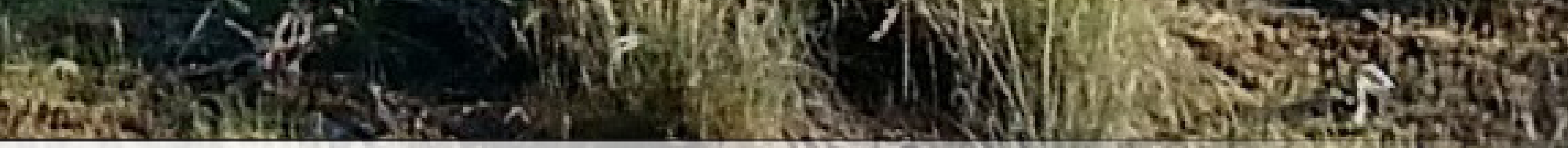

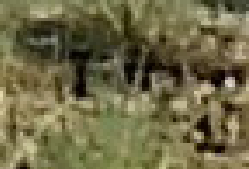

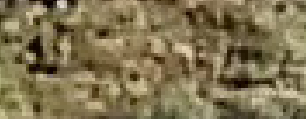
1) 


\title{
U.S. Geological Survey Sagebrush Ecosystem Research Annual Report for 2020
}

\author{
Edited by Steven E. Hanser and Lief A. Wiechman
}

\section{Research To Support the Management of the Sagebrush Ecosystem}

The sagebrush (Artemisia spp.) ecosystem extends across 251,473 square miles over portions of 13 western States (fig. 1). Affected by multiple stressors, including interactions among fire, invasive plants, and human land uses, this ecosystem has experienced significant loss, fragmentation, and degradation of landscapes once dominated by sagebrush (Knick and Connelly, 2011; Chambers and others, 2017). In turn, wildlife populations have declined following these deleterious conditions. Federal, State, local, and Tribal agencies, nongovernmental organizations, and industry have been galvanized by declining wildlife populations to implement management actions to confront the impacts of these stressors and ensure the long-term availability of the sagebrush ecosystem for the broad range of uses critical to stakeholders in the Western United States.

The sagebrush ecosystem provides habitat for more than 350 species of plants and animals that are dependent on sagebrush for all or part of their annual life history (Wisdom and others, 2005). The greater sage-grouse (Centrocercus urophasianus) stands out as an iconic species of this ecosystem. Sage-grouse populations occur in 11 States, and 2 Canadian Provinces and require relatively large expanses of sagebrush-dominated habitat to meet all their seasonal habitat needs (fig. 1). Recent management actions to

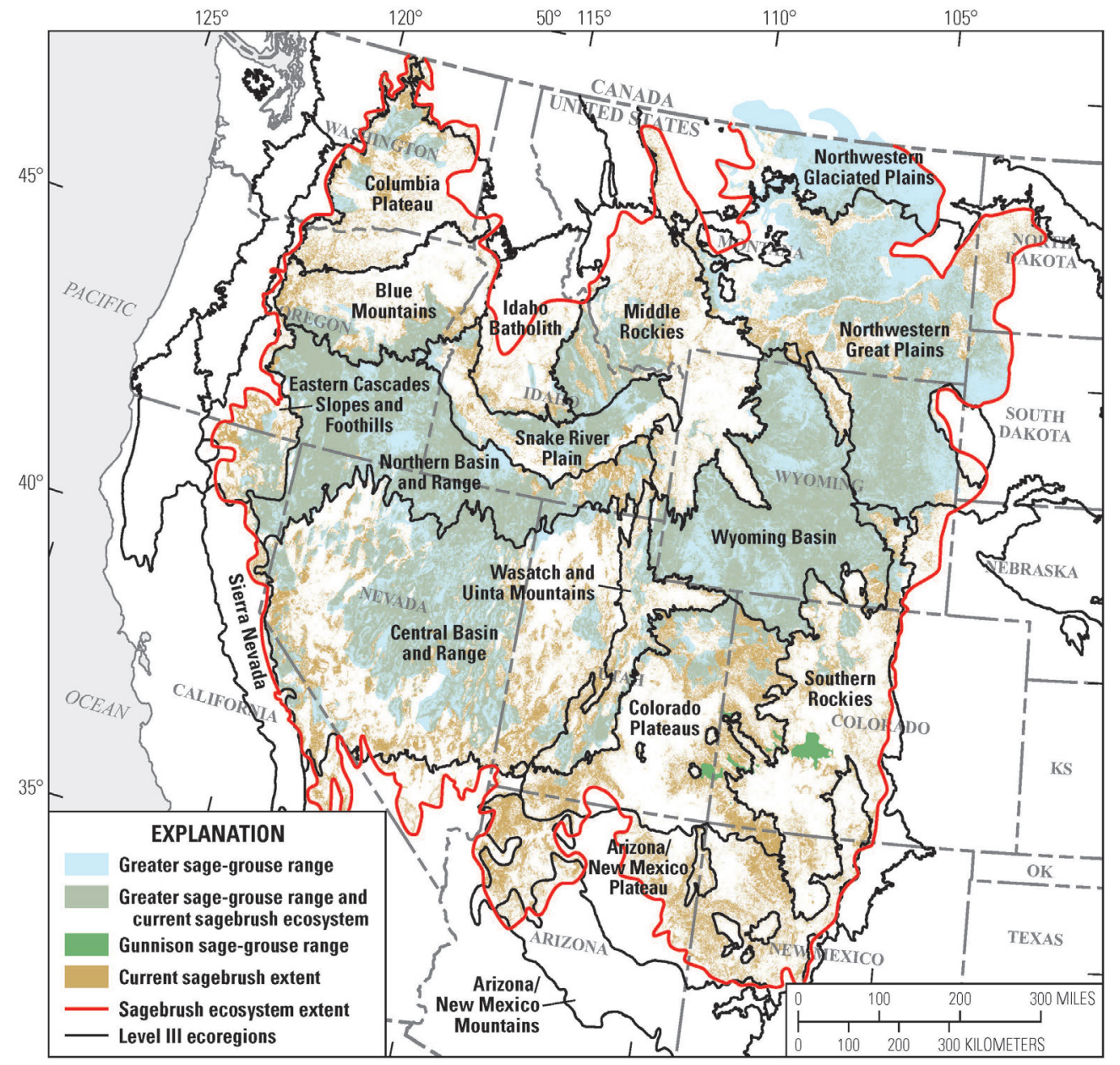

Figure 1. Location of the sagebrush ecosystem, distribution of greater and Gunnison sage-grouse, and the current sagebrush extent in the Western United States. U.S. Environmental Protection Agency Level III ecoregions are labeled on the map. The Great Basin is composed of the Central Basin and Range, Northern Basin and Range, and Snake River Plain ecoregions. Sagebrush ecosystem extent data are from Jeffries and Finn (2019), greater sage-grouse range data are from the U.S. Fish and Wildlife Service (2016), Gunnison sage-grouse range data are from Schroeder and others (2004), and current sagebrush distribution data are from Jeffries and others (2019). 
conserve and maintain the sagebrush ecosystem have focused on the protection and restoration of sage-grouse habitat (Chambers and others, 2017); however, each of the 350 species has a unique life history and differing area requirements (for example, large areas for mule deer [Odocoileus hemionus] and small areas for pygmy rabbit [Brachylagus idahoensis]), and some species, such as migratory birds, rely on various parts of the sagebrush ecosystem but only for part of the year (for example, Brewer's sparrow [Spizella breweri]).

The U.S. Geological Survey (USGS) has a broad research program focused on the sagebrush ecosystem, wildlife species within the ecosystem, and the species' response to stressors and management actions. The program provides a foundation of scientific information for use in major land and resource management decisions in the sagebrush ecosystem. By providing the science to inform these decisions, the USGS is assisting land and resource managers at the Federal, State, Tribal, and local levels working towards the goal of sustainable wildlife populations and restored landscapes. This information can inform planning and management conducted by nongovernmental organizations as well.

USGS research is tailored specifically to inform adaptive management, improve strategies for maintaining existing areas of intact sagebrush, and restoring degraded landscapes. Examples of research support for partners include providing information for actions such as the preclusion of the need to list the greater sage-grouse under the Endangered Species Act and recent revisions to Bureau of Land Management (BLM) and U.S. Department of Agriculture (USDA) Forest Service resource management plans and land use. The USGS continues to provide foundational science to inform science-based decisions within the U.S. Department of the Interior (DOI) and other Federal, State, and local agencies and their continued conservation, management, and restoration of the sagebrush ecosystem to help support local economies.

\section{Structure of the U.S. Geological Survey Sage-Grouse and Sagebrush Ecosystem Research Program}

The U.S. Geological Survey Sage-Grouse and Sagebrush Ecosystem Research Program includes scientists from 3 of the 7 USGS Mission Areas and is led out of the USGS National Center, Ecosystems Mission Area, with leadership and research scientists located in 11 western States in the following locations:

\section{Ecosystems Mission Area}

\section{National Center}

- Ecosystems Mission Area, Reston, Va., and Fort Collins, Colo

\section{Science Centers}

- Forest and Rangeland Ecosystem Science Center, Corvallis, Oreg., and Boise, Idaho

- Fort Collins Science Center, Fort Collins, Colo., and Santa Fe, N. Mex.

- Northern Rocky Mountain Science Center, Bozeman, Mont.

- Southwest Biological Science Center, Flagstaff, Ariz., and Moab, Utah

- Western Ecological Research Center, Sacramento, Dixon, and Oakhurst, Calif.

\section{Cooperative Research Units}

- Colorado Cooperative Fish and Wildlife Research Unit, Fort Collins, Colo.

- Idaho Cooperative Fish and Wildlife Research Unit, Moscow, Idaho

- Oregon Cooperative Fish and Wildlife Research Unit, Corvallis, Oreg.

- Montana Cooperative Wildlife Research Unit, Missoula, Mont.
- Utah Cooperative Fish and Wildlife Research Unit, Salt Lake City, Utah

- Wyoming Cooperative Fish and Wildlife Research Unit, Laramie, Wyo.

\section{Land Resources Mission Area}

\section{Science Centers}

- Earth Resources Observation Science Center, Sioux Falls, S. Dak., and Boise, Idaho

- Geosciences and Environmental Change Science Center, Denver, Colo.

\section{Climate Adaptation Science Centers}

- North Central Climate Adaptation Science Center, Fort Collins, Colo.

- Northwest Climate Adaptation Science Center, Seattle, Wash.

- Southwest Climate Adaptation Science Center, Tucson, Ariz.

\section{Energy and Minerals Mission Area}

\section{Science Centers}

- Central Energy Resources Science Center, Denver, Colo. 


\section{List of Projects}

USGS sage-grouse and sagebrush ecosystem research is aligned with priority needs outlined in the "Integrated Rangeland Fire Management Strategy Actionable Science Plan" (Integrated Rangeland Fire Management Strategy Actionable Science Plan Team, 2016). The list of 116 research projects is organized into five thematic areas: fire (16 projects); invasive species (7 projects); restoration (23 projects); sagebrush, sage-grouse, and other sagebrush-associated species ( 60 projects); and weather and climate (10 projects). Individual projects often overlap multiple themes (for example, effects of wildfire and invasive annual grasses on greater sage-grouse habitat); therefore, project descriptions are organized according to the main focal theme.

Fire..

Evaluating Effects and Effectiveness of Fuel Breaks

Assessing the Effectiveness of Fuel Breaks for Preserving Greater Sage-Grouse in the Great Basin.............................8

Effects of Fuel Breaks on Surrounding Vegetation ..............................................................................................

Developing and Evaluating Fuel Break Performance Metrics Across Spatiotemporal Scales and for Multiple Risk

Factors in Sagebrush Landscapes of the Great Basin ...................................................................................9

Evaluating Effects of Woody Fuel Treatments on Native and Nonnative Plants in the Sagebrush Biome.........................10

Assessing the Proliferation, Connectivity, and Consequences of Invasive Fine Fuels......................................................11

Long-Term Effects of Treatments on Fuel Loads and Fire Regimes in the Great Basin ....................................................11

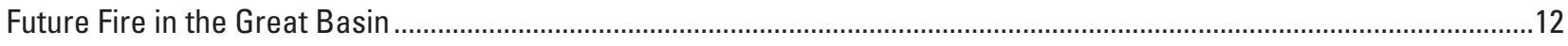

Identifying the Effects of Reoccurring Fire on Sagebrush Ecosystems in the Northern Columbia Basin.........................13

Using the Past and the Present To Understand Fire Ecology in the Range of the Gunnison Sage-Grouse .......................14

Effects of Large-Scale Wildfire on Habitat Use and Demography of Female Greater Sage-Grouse in

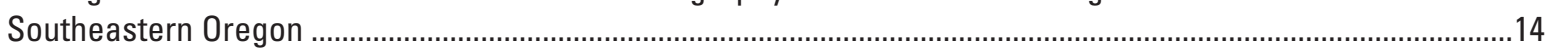

Wildfire Effects on Sage-Grouse-A Before and After Case Study ............................................................................15

Effects of Wildfire and Climate on Persistence of Greater Sage-Grouse ......................................................................15

Perennial Grass Response to Postfire Grazing Management in the Great Basin ...........................................................16

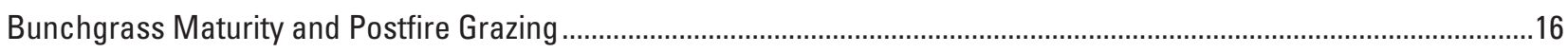

How Fire and Postfire Seeding Alter Pollinators in Sagebrush Habitat .........................................................................16

Pollinator Use of Forbs in the Soda Wildfire Area ................................................................................................17

Environmental and Fire Interactions in Northern Great Basin Vegetation Communities .................................................17

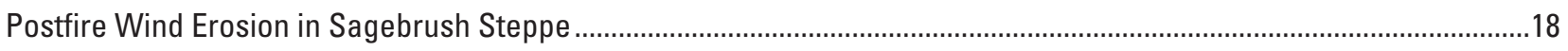

Invasive Species.....................................................................................................................................................................19

Compiling and Summarizing Recent Science and Data on Invasive Annual Grasses for Land Managers.......................20

Invasive Annual Grass Product Development for the Western United States ....................................................................20

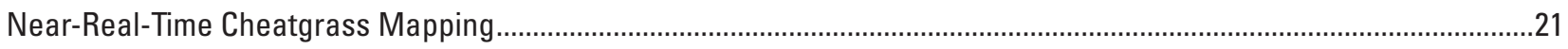

Sagebrush Ecosystem Management in Light of Sage-Grouse, Fire, and Invasive Species .............................................22

Spatial Variation in the Role of Climatic Extremes in Shaping Plant Invasions...........................................................23

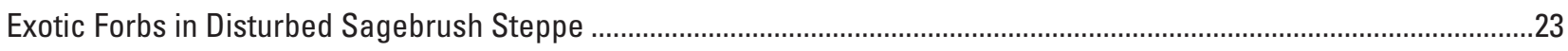

Landscape-Scale Assessment of Emerging Techniques for Controlling Exotic Annual Grasses......................................24

Use of Cheatgrass-Suppressive Bacteria to Restore Sagebrush Steppe ....................................................................25

Evaluating a Novel Biopesticide for Controlling Exotic Annual Grasses Following Rangeland Wildfire...........................25

Sweet Clover Encroachment and Effects on Sage-Grouse Habitat Quality ...................................................................26

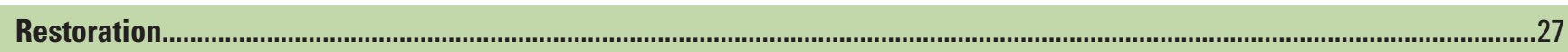

Field of Sagebrush Dreams-Sage-Grouse Responses to Burns and Sagebrush Restoration in

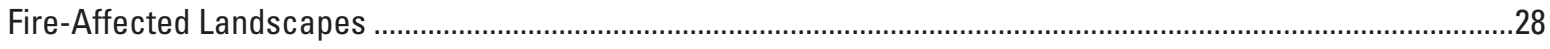

Restoration of Native Understory Plants in Degraded Sagebrush Steppe Ecosystems .................................................28

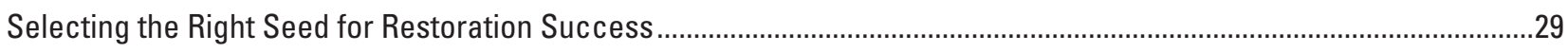


SageSuccess Project-Sagebrush Restoration for Sage-Grouse . .30

Assessing the Influence of Microsite Soil Characteristics on Sagebrush Restoration Success.........................................30

Soda Wildfire Response — Integrating Science into Adaptive Management .......................................................................31

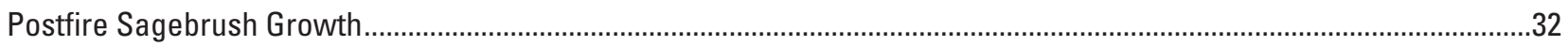

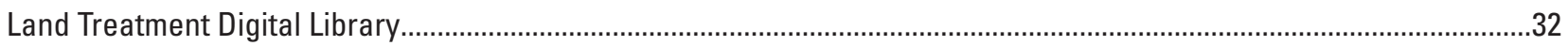

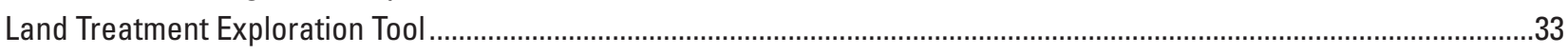

Decision Support for Conservation and Restoration Efforts in the Sagebrush Biome ....................................................34

Optimization of Management Actions for Restoration Success and Wildlife Populations ....................................................34

Interpreting Indicators of Rangeland Health ..............................................................................................

Effectiveness of Layering Treatments in the "Multiple Intervention" Response to Wildfire in Sagebrush Steppe ...........35

Phasing Herbicide, Drill Seeding, and Grazing Resumption in Postfire Sagebrush Steppe .............................................35

Experimental Tests of Management Options for Improving Outplanting Success of Big Sagebrush.................................36

The Biggest Bang for the Buck-Cost-Effective Vegetation Treatment Outcomes Across Drylands of the Western

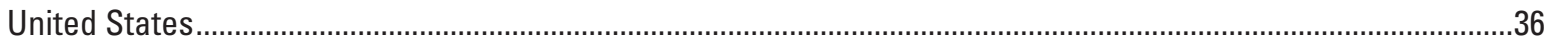

Community Composition and Restoration of Biological Soil Crusts of Nevada's Sagebrush Shrublands.........................37

Holding Their Ground—Does Biological Soil Crust Restoration Enhance the Germination of Native Plants and

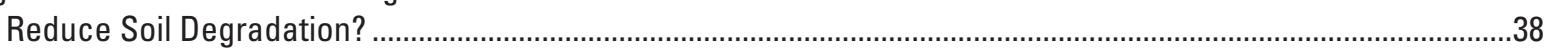

Understanding the Ecological Importance of Biocrusts and Grazing Prescriptions That Minimize

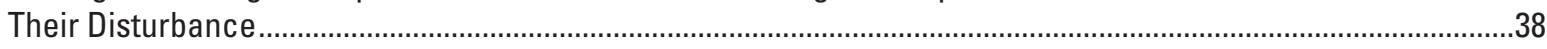

Increasing Operational Resilience for Sagebrush Ecosystems by Integrating Multiscale Sage-Grouse Metrics.............38

Bureau of Land Management Seed Warehouse Database.......................................................................................39

Modeling Recovery of Sagebrush Ecosystems Across the Sage-Grouse Range Using Remotely Sensed

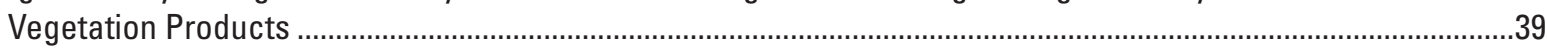

Standards, Methods, and Monitoring — Improving Reclamation Success on Western Public Lands ..............................40

Evaluating Reclamation Success Following Oil and Gas Development .........................................................................40

Using Long-Term Remote Sensing and an Automated Reference Toolset to Estimate and Predict Postdevelopment

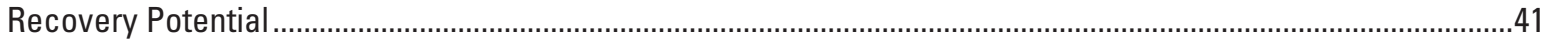

Landowner Decision Making and Landscape-Level Restoration..............................................................................41

Economic Implications of Sagebrush Treatment and Restoration Practices Across the Great Basin and Wyoming .......42

Sagebrush, Sage-Grouse, and Other Sagebrush-Associated Species ...................................................................................43

Hierarchical Sage-Grouse Population Assessment Tool—Building a Foundation for True Adaptive Management .........44

Western Association of Fish and Wildlife Agencies Sagebrush Conservation Strategy ....................................................4

Annotated Bibliography of Scientific Research on Greater Sage-Grouse ..................................................................4

Using Advanced Technologies to Improve Population Estimation from Lek Counts........................................................45

Marking Effects on Sage-Grouse Survival and Behavior ...........................................................................................46

Importance of Simulation Assumptions When Evaluating Detection Bias in Lek Trend Models.........................................46

Evaluating Trends in Greater Sage-Grouse Populations With Quantile Regression.........................................................47

A Hierarchical Integrated Population Model for Greater Sage-Grouse in the Bi-State Distinct Population

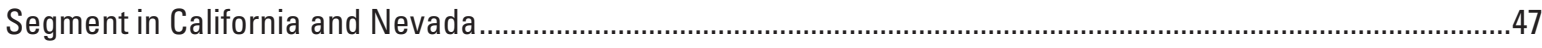

Spatially Explicit Conservation Planning Tool for the Bi-State Distinct Population Segment of

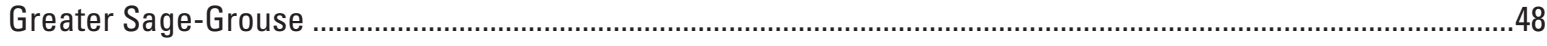

Can Translocation Prevent the Loss of Imperiled Populations of Sage-Grouse in the Bi-State Distinct Population Segment?.....................................................................................................................................48

Greater Sage-Grouse Response to Habitat Restoration Efforts ......................................................................................49

Spatially Explicit State-and-Transition Modeling for Rangeland Conservation Planning-Application to

Outcome-Based Grazing and Sage-Grouse Habitat Monitoring..........................................................................4

Impacts of Free Roaming Equids and Livestock on Greater Sage-Grouse and Sagebrush Ecosystems ..........................50

Reintroduction and Population Establishment of Columbian Sharp-Tailed Grouse Within Sagebrush Ecosystems in Nevada. 
Decision Support Models for Effective Population Restoration Through Translocation of Prairie-Grouse and Sage-Grouse

Integrating Wildlife Habitat Models With State-And-Transition Models to Enhance the Management of Rangelands for Multiple Objectives. . .51

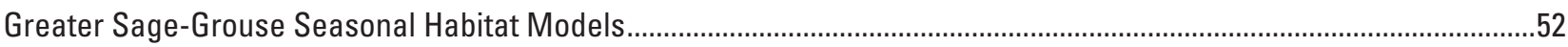

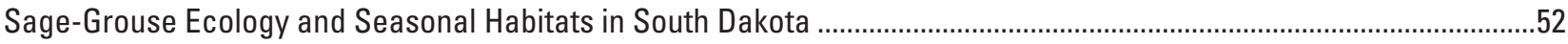

Seasonal Habitat Maps for Sage-Grouse in Montana and the Dakotas.........................................................................52

Mapping of Greater Sage-Grouse Habitat in Nevada and Northeastern California ........................................................53

Microhabitat Requirements of Greater Sage-Grouse Within the Great Basin ............................................................54

Informing the Habitat Assessment Framework Process-An Assessment to Understand Habitat Patch

Composition and Configuration Requirements for Range-Wide Sage-Grouse Persistence ...................................54

SageDAT—Data and Tools to Support Collaborative Sagebrush Ecosystem Conservation and Management..................55

Remote Sensing Characterization and Monitoring of Shrubland Components in the Western United States...................55

Developing Temporal Trends in Sagebrush Vegetation Characteristics Over a Large Landscape ....................................56

Understanding Drivers of Change in Rangeland Vegetation ................................................................................5

Rangeland Ecological Potential Based on Long-Term Satellite Archives..................................................................58

Mapping Conifer Encroachment Within California and Nevada ..........................................................................58

Unmanned Aerial Systems for Improving Satellite-Derived Maps of Vegetation..............................................................59

Sagebrush Ecosystem Performance Mapping in the Great Basin ..........................................................................60

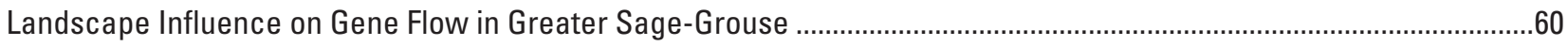

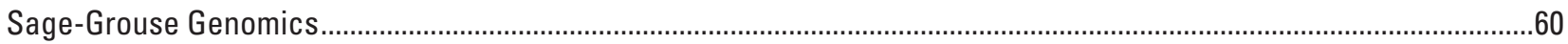

Incorporating Genetic Information Into Population Monitoring and Assessment Tools ...................................................61

Genomic Scans for Local Adaptation in Greater Sage-Grouse ....................................................................................61

Developing Efficient Genomic Monitoring Tools for Sage-Grouse...............................................................................62

Leveraging Sage-Grouse Genomes to Inform Appropriate Sagebrush Restoration Practices .........................................62

Connecting Hubs of Genetic Exchange Across the Range of Greater Sage-Grouse-Prioritizing Corridors for

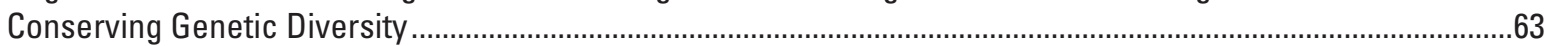

Identifying Corridors and Connectivity Within and Among Sage-Grouse Priority Areas of Conservation Rangewide .....63 Integration of Genetic and Demographic Data to Assess the Relative Importance of Connectivity and Habitat in

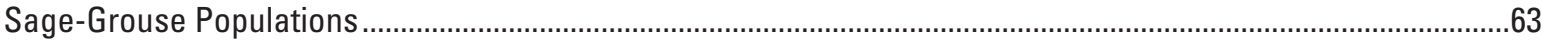

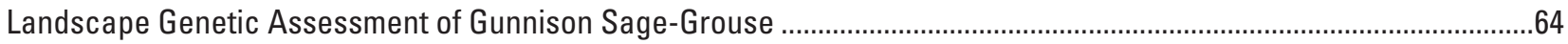

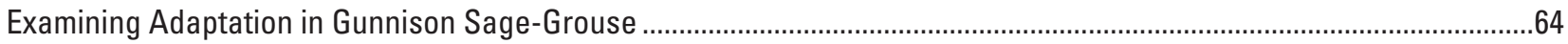

Identification of Crucial Late-Summer Brood-Rearing and Winter Habitat for Gunnison Sage-Grouse ............................64

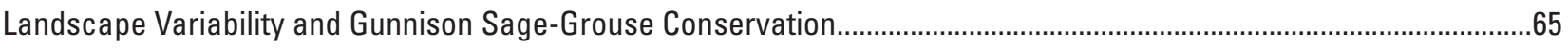

Assessing Habitat, Risk, and Conservation Actions for Gunnison Sage-Grouse .............................................................65

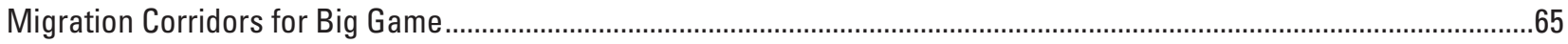

Greater Sage-Grouse and Mule Deer Population Viability Analysis Across Scales ......................................................66

Use of Sagebrush-Reduction Treatments by Mule Deer in Wyoming .........................................................................67

Interactions of Phenology, Grazing, Hunting, and Prescribed Fire on Elk and Mule Deer in

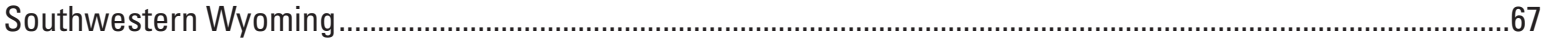

Measuring Elk Density and Changes in Aggregation to Mitigate Risk of Disease in Sagebrush Ecosystems ...................68

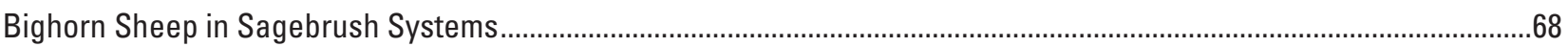

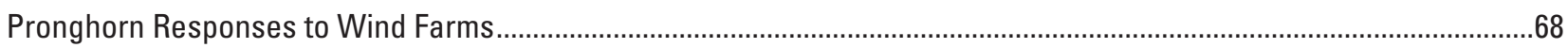

Ecological Disturbances of Wind Energy in Wyoming ..............................................................................................69

Using Genetic Analyses to Inform On-the-Ground Conservation for Multiple Sagebrush-Associated

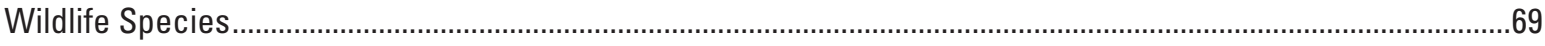

Sage-Grouse as an Umbrella Species for Nongame Species of Concern in Wyoming ...................................................69

Evaluating Biodiversity of Sagebrush-Dependent Species Within Sage-Grouse Habitat—An Example from the Wyoming Basins.. 
Influence of Climatic Conditions on Reproduction of Sagebrush-Dependent Birds-Implications for Climate Vulnerability Assessments and Habitat Prioritization Efforts ...

Full Life-Cycle Analysis of Wyoming's Sagebrush-Obligate Songbirds......................................................................71

Developing Regional and Local Decision Support Tools for Sagebrush and Grassland Ecosystems in

Northeastern Wyoming

Modeling Habitat-Relationships of Pinyon-Juniper and Sagebrush Associated Bird Species to Inform

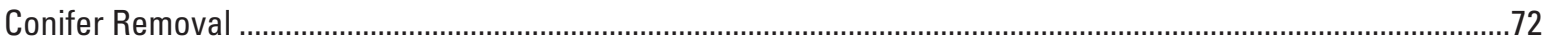

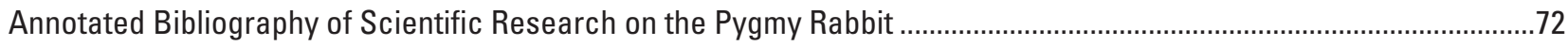

Smart Energy Development in the Sagebrush Ecosystem ....................................................................................................73

Quantifying the Potential Effects of Energy Development on Wildlife and Ecosystem Services.......................................73

Mechanisms Underlying Sagebrush-Obligate Songbird Responses to Natural Gas Development.....................................74

Distance Effects of Oil and Gas Field Infrastructure on Pygmy Rabbits ....................................................................74

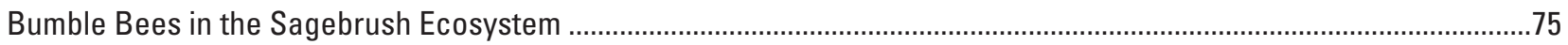

Pollinator Assessment and Conservation.............................................................................................................75

Restoring Sandberg Bluegrass Communities to Protect Packard's Milkvetch Habitat and Reduce Fuel Loadings...........76

Vulnerability of Aspen Stands in Sagebrush Ecosystems to Altered Fire and Climate Dynamics.....................................76

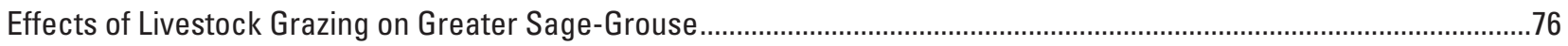

Effects of Invasive Cheatgrass on Sage-Grouse in Nevada ..................................................................................77

Implications of Anthropogenic Activities on Greater Sage-Grouse Populations in Nevada .............................................77

Understanding How Changes in Traffic Volume May Affect Sage-Grouse Population Dynamics Across Scales

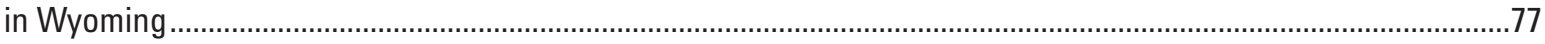

Effects of Pinyon and Juniper on Sage-Grouse Movement, Distribution, and Survival ....................................................78

Predation Effects on Sage-Grouse Population Dynamics .............................................................................................79

Raven Density and Management Across the Great Basin ....................................................................................79

Effects of Raven Removal on Nest Survival and Population Growth Rates of Greater Sage-Grouse................................80

Decision Support Tool for Managing Expanding Common Raven Populations and Assessing Risks to

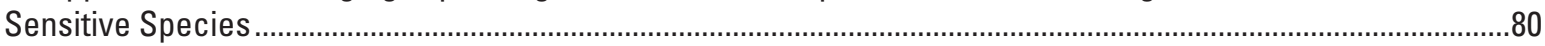

Plant Community Composition and Vegetation Structure in Core Sage-Grouse Habitats .................................................81

Encyclopedia of the World's Biomes_-Sagebrush Steppe and Shrubland ..................................................................82

Defining Multi-Scaled Functional Landscape Connectivity for the Sagebrush Biome to Support Management

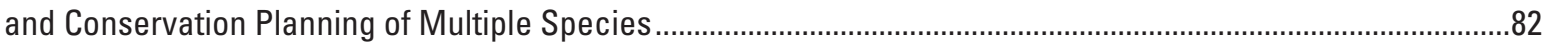

Building the Sage-Grouse Umbrella with Songbird Habitat Models .........................................................................

Modeling Habitat and Assessing Threats for Lizards and Snakes in Sagebrush Ecosystems .........................................84

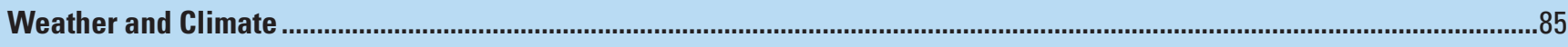

Mapping Projected Soil Temperature and Moisture Regimes in a Changing Climate......................................................86

Soil-Climate Modeling to Improve Understanding of Pattern and Processes in Sagebrush Ecosystems-

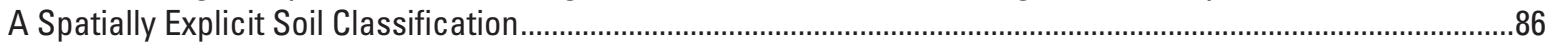

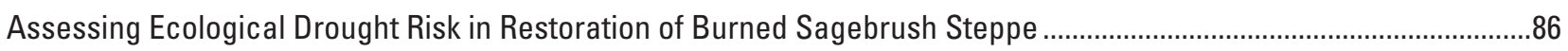

Assessing Vulnerability to Drought in Dryland Ecosystems of the Western United States.................................................87

A Climate Vulnerability Assessment Framework for Data-Poor Species.........................................................................87

Assessing the Future of Sagebrush Ecosystems with Changing Precipitation and Temperature......................................88

Forecasting the Spatiotemporal Dynamics of Sagebrush in Wyoming Under a Changing Climate ....................................89

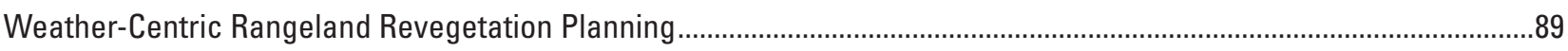

Response of Sagebrush Ecosystems to Precipitation Shifts ...................................................................................90

Surface Energy Fluxes and Balance Components, Soil Moisture, and Evapotranspiration in a

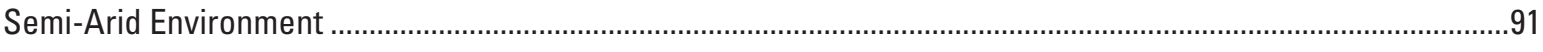

Phenological Responses to Environmental Drivers in the Northern Great Plains...........................................................91

Tracking Drought-Induced Variability in Sagebrush Ecosystem Productivity.................................................................92

Sagebrush Ecosystem Research Funded by Climate Adaptation Science Centers............................................................92 


\section{Project Descriptions}

These descriptions are overviews of projects that are ongoing or were active during 2020. Each theme area is described briefly, followed by individual project overviews. Citations are provided for select products that have resulted from these efforts. Contact information is provided for the primary USGS scientist(s) for each project.

\section{Fire}

Fire is a significant threat to maintaining a large contiguous sagebrush ecosystem, and this threat has been intensifying, owing to increases in highly flammable invasive annual grasses. USGS scientists are continuing to address science needs, including determining the effects and effectiveness of fuel treatments, understanding historic and potential future fire regimes in the sagebrush ecosystem, evaluating effects of fire on species, and assessing strategies to improve postfire management actions. 


\section{Evaluating Effects and Effectiveness of Fuel Breaks}

Fuel breaks are intended to reduce fire size, frequency, and the rate at which fire spreads by disrupting fuel continuity, reducing fuel accumulation, or increasing plants with higher moisture content in strips or blocks of land. Land management agencies want better information about the effectiveness of fuel breaks, as well as potential ecological costs and benefits related to fuel breaks. To supply this information, USGS and USDA Forest Service scientists have synthesized available information on the ecological effects and effectiveness of fuel breaks, particularly linear fuel breaks across the Great Basin (fig. 1). By evaluating the extent to which fuel breaks protect existing habitat from wildland fire, as well as how they affect sagebrush habitat, sage-grouse, and other sagebrush-obligate species, this study provides information for managers as they assess tradeoffs between the

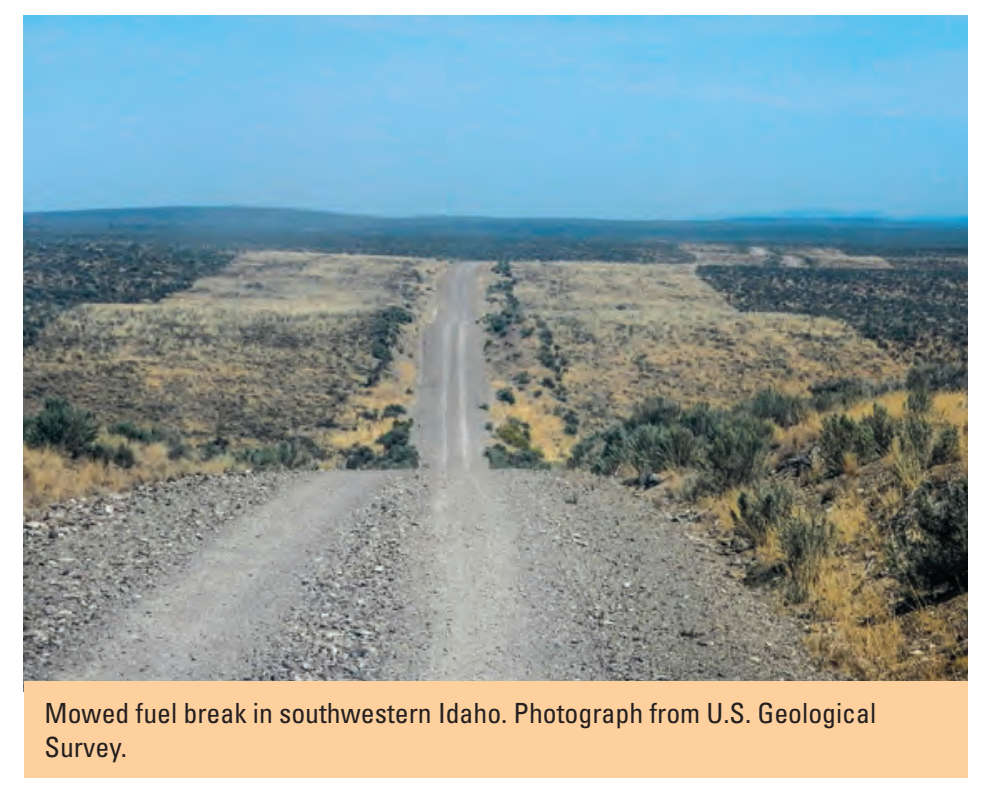
potential risks and benefits of fuel breaks.

\section{Contact}

Douglas J. Shinneman, USGS Forest and Rangeland Ecosystem Science Center; dshinneman@usgs.gov; 208-426-5206

\section{Publications}

Shinneman, D.J., Aldridge, C.L., Coates, P.S., Germino, M.J., Pilliod, D.S., and Vaillant, N.M., 2018, A conservation paradox in the Great Basin-Altering sagebrush landscapes with fuel breaks to reduce habitat loss from wildfire: U.S. Geological Survey Open-File Report 2018-1034, 70 p., https://doi.org/10.3133/ofr20181034.

Shinneman, D.J., Germino, M.J., Pilliod, D.S., Aldridge, C.L., Vaillant, N.M., and Coates, P.S., 2019, The ecological uncertainty of wildfire fuel breaks - Examples from the sagebrush steppe: Frontiers in Ecology and the Environment, v. 17, no. 5, p. 279-288, https://doi.org/10.1002/fee.2045.

\section{Assessing the Effectiveness of Fuel Breaks for Preserving Greater Sage-Grouse in the Great Basin}

Fuel breaks have the potential to minimize catastrophic losses of sagebrush habitat and sage-grouse populations by altering fire behavior and facilitating fire suppression. However, they may carry risks to sage-grouse populations —of habitat loss, fragmentation, cheatgrass (Bromus tectorum) invasion, and alteration of sage-grouse movements - that have not been quantified. USGS and Colorado State University (CSU) scientists are working with the BLM to (1) map fuel breaks and quantify sage-grouse response to fuel breaks; (2) use high-resolution spatial data to compare fire sizes and spread among areas with and without fuel breaks; (3) model changes in sage-grouse habitat and populations under alternative scenarios of wildfire and fuel break effectiveness, and sage-grouse responses to linear fuel breaks; and (4) develop and compare alternative fuel break placement strategies to conserve sage-grouse habitats and populations. Results of this study can help identify the important factors to consider for the implementation and placement of fuel breaks to suppress wildfire in sage-grouse habitats while minimizing negative impacts on populations.

\section{Contacts}

Cameron L. Aldridge, USGS Fort Collins Science Center; aldridgec@usgs.gov; 970-226-9433

Julie A. Heinrichs, Colorado State University, in cooperation with USGS Fort Collins Science Center; jheinrichs@usgs.gov; 970-226-9149

Peter S. Coates, USGS Western Ecological Research Center; pcoates@usgs.gov; 530-669-5073

Douglas J. Shinneman, USGS Forest and Rangeland Ecosystem Science Center; dshinneman@usgs.gov; 208-426-5206 


\section{Effects of Fuel Breaks on Surrounding Vegetation}

Invasive species such as cheatgrass have disrupted the sagebrush fire cycle by increasing the frequency of fires. Invasive grasses dry early in the wildfire season and provide continuous cover for fire to spread quickly. In the wake of fire, restoration activities are increasingly using fuel breaks to reduce the spread of fire proactively. Although fuel breaks could assist restoration, they are also often planted with nonnative species that are persistently green. As part of the Soda Fire Fuel Breaks Project, USGS researchers are helping Idaho Office of Species Conservation, BLM, and U.S. Fish and Wildlife Service (FWS) managers by investigating how fuel breaks affect surrounding plant communities across a range of landscape characteristics. Specifically, researchers are studying whether and under what circumstances fuel break plant species invade restoration plots and the invasion of fuel breaks from other species. Field measurements on many plots from this project are used to parameterize fire behavior models (such as the Fuel Characteristics Classification System and Behave Plus), or landscape fire spread models (such as Circuitscape and QUIC-Fire), and Minimum Travel Time models (such as Randig). Results can inform future restoration design, installation, maintenance, and monitoring to assess the effectiveness over time

\section{Contact}

Matthew J. Germino, USGS Forest and Rangeland Ecosystem Science Center; mgermino@usgs.gov; 208-426-3353

\section{Developing and Evaluating Fuel Break Performance Metrics Across Spatiotemporal Scales and for Multiple Risk Factors in Sagebrush Landscapes of the Great Basin}

Fuel breaks involve the removal or modification of vegetation communities to strategically disrupt fuel continuity and reduce fuel loads. Fuel break performance is difficult to assess accurately because systematically collected information on fuel break design, placement, and effectiveness is limited. Ideally, fuel break performance would be assessed systematically across multiple scales, ranging from specific points in time and space to multiple locations over time, and fully consider the affected natural and human landscapes. USGS scientists are identifying and developing an initial set of performance metrics for fuel breaks relevant to altering wildfire behavior, and addressing risks and ecological effects. In addition, fire behavior models are being used to test a range of performance metrics relative to alternative Great Basin fuel break scenarios and to evaluate synergies and tradeoffs for each scenario using a cost-benefit decision framework. This framework also permits identification of needed improvements to fuel, fire, and wildlife modeling approaches, and has the capacity to refine key metrics and improve modeling approaches as new information becomes available.

\section{Contact}

Douglas J. Shinneman, USGS Forest and Rangeland Ecosystem Science Center; dshinneman@usgs.gov; 208-426-5206 


\section{Evaluating Effects of Woody Fuel Treatments on Native and Nonnative Plants in the Sagebrush Biome}

When sagebrush becomes overcrowded, the risk of wildfire increases; that risk can also rise with increasing pinyon (Pinus spp.) and juniper (Juniperus spp.) cover. Managers often use various techniques to reduce woody fuels and thereby reduce fire risk and benefit sagebrushdependent birds, particularly sage-grouse, but these techniques may have undesirable consequences for native vegetation. USGS scientists and collaborators, as part of the Sagebrush Steppe Treatment Evaluation Project (SageSTEP), evaluated a combination of prescribed fire, mowing, mechanical, and herbicide treatments to reduce woody shrubs and trees to study how treatments affected other plant species, land health indicators, and wildlife. During the SageSTEP project, scientists have completed 10 or more years of research at various sites to provide information on the long-term outcomes of these treatments and support decision making regarding the various methods.

\section{Contact}

David A. Pyke, USGS Forest and Rangeland Ecosystem Science Center; david_a_pyke@usgs.gov; 541-7500989

\section{Publications}

Chambers, J.C., Miller, R.F., Board, D.I., Pyke, D.A., Roundy, B.A., Grace, J.B., Schupp, E.W., and Tausch, R.J., 2014, Resilience and resistance of sagebrush ecosystems - Implications for state and transition models and management treatments: Rangeland Ecology \& Management v. 67, no. 5, p. 440-454, https://doi.org/10.2111/REM-D-13-00074.1.

Knick, S.T., Hanser, S.E., and Leu, M., 2014, Ecological scale of bird community response to piñon-juniper removal: Rangeland Ecology \& Management, v. 67, no. 5, p. 553-562, https://doi.org/10.2111/REM-D-13-00023.1.

Knick, S.T., Hanser, S.E., Grace, J.B., Hollenbeck, J.P., and Leu, M., 2017, Response of bird community structure to habitat management in piñon-juniper woodland-sagebrush ecotones: Forest Ecology and Management, v. 400, September, p. 256-268, https://doi.org/10.1016/j.foreco.2017.06.017.

Pyke, D.A., Shaff, S.E., Lindgren, A.I., Schupp, E.W., Doescher, P.S., Chambers, J.C., Burnham, J.S., and Huso, M.M., 2014, Region-wide ecological responses of arid Wyoming big sagebrush communities to fuel treatments: Rangeland Ecology \& Management, v. 67, no. 5, p. 455-467, https://doi.org/10.2111/REM-D-13-00090.1.

Roundy, B.A., Chambers, J.C., Pyke, D.A., Miller, R.F., Tausch, R.J., Schupp, E.W., Rau, B., and Gruell, T., 2018, Resilience and resistance in sagebrush ecosystems are associated with seasonal soil temperature and water availability: Ecosphere, v. 9, no. 9, article e02417, https://doi.org/10.1002/ecs2.2417. 


\section{Assessing the Proliferation, Connectivity, and Consequences of Invasive Fine Fuels}

Invasive annual grasses (fine fuels) are a significant challenge for land and wildlife management. USGS and CSU scientists are working with the BLM to understand the potential consequences of invasive annual grass proliferation and connectivity on fire behavior and loss of sagebrush in the Great Basin. Landscape disturbances and management activities that create linear features (for example, roads, fuel breaks, transmission lines) often occur adjacent to existing fine fuels and may lead to further spread of invasive annual grasses. The scientists are developing a spatial cheatgrass model that identifies locations at risk of invasion and evaluating future disturbance scenarios that assess the potential impacts of future invasions caused by fuels management and other surface disturbance activities. Additional research is being conducted to evaluate the connectivity of flammable annual grasses and simulate the effectiveness of alternative approaches to disconnecting fine fuels to reduce fire spread. This project can help develop strategies for managing annual invasive grasses, thus minimizing the potential loss of sage-grouse habitat.

\section{Contacts}

Julie A. Heinrichs, Colorado State University, in cooperation with USGS Fort Collins Science Center; jheinrichs@usgs.gov; 970-226-9149

Helen R. Sofaer, USGS Pacific Island Ecosystems

Research Center; hsofaer@usgs.gov; 808-985-6444

Daniel J. Manier, USGS Fort Collins Science Center; manierd@usgs.gov; 970-226-9466

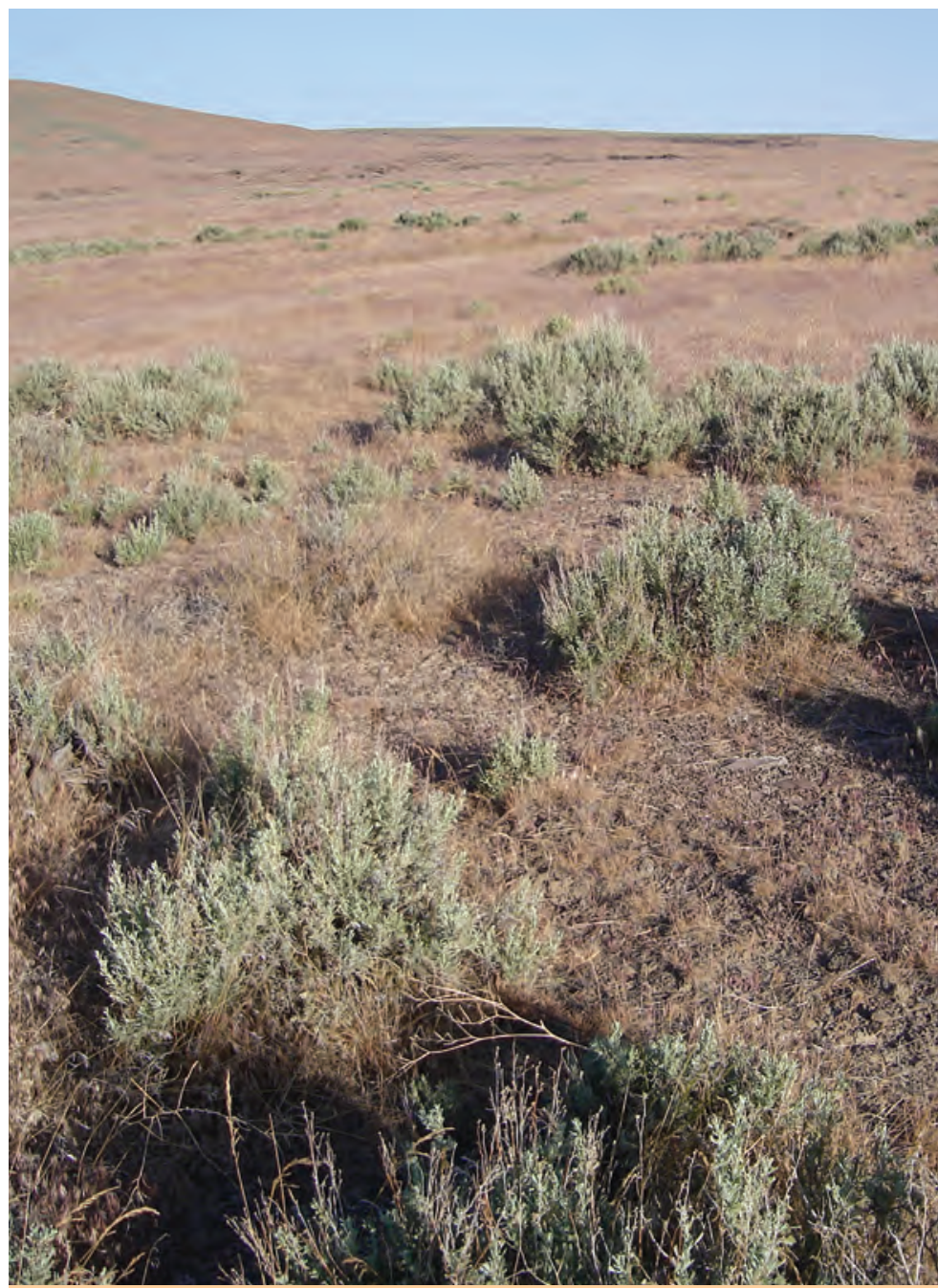

Cheatgrass in southern Idaho. Photograph by Steven Hanser, U.S. Geological Survey.

\section{Long-Term Effects of Treatments on Fuel Loads and Fire Regimes in the Great Basin}

The Great Basin is vulnerable to changes in fuels and fire regimes as a result of invasive species and climate change. To address these threats, management agencies are using fuel reduction and seeding treatments designed to reduce fire intensity, spread, and risk. To assess the ecological impacts and long-term effectiveness of these treatments, USGS scientists and university collaborators are evaluating future scenarios of ecosystem dynamics using models that incorporate climatic parameters (temperature, precipitation), fire regimes, and fuel treatments. They are examining potential vegetation response to changing climate, fuel treatments, and postfire seedings and assessing implications for repeated fuels maintenance under several future climate scenarios. Results may be used by land managers and fuels experts engaged in sagebrush ecosystem land use planning and fire management activities, including in the design of more effective fire suppression strategies.

\section{Contacts}

Douglas J. Shinneman, USGS Forest and Rangeland Ecosystem Science Center; dshinneman@usgs.gov; 208-426-5206

David S. Pilliod, USGS Forest and Rangeland Ecosystem Science Center; dpilliod@usgs.gov; 208-426-5202 


\section{Publications}

Pandit, K., Dashti, H., Glenn, N.F., Flores, A.N., Maguire, K.C., Shinneman, D.J., Flerchinger, G.N., and Fellows, A.W., 2019, Developing and optimizing shrub parameters representing sagebrush (Artemisia spp.) ecosystems in the northern Great Basin using the Ecosystem Demography (EDv2.2) model: Geoscientific Model Development, v. 12, p. 4585-4601, https://doi.org/10.5194/gmd-12-4585-2019.

Pilliod, D.S., Welty, J.L., and Arkle, R.S., 2017, Refining the cheatgrass-fire cycle in the Great Basin-Precipitation timing and fine fuel composition predict wildfire trends: Ecology and Evolution, v. 7, no. 19, p. 8126-8151, https://doi.org/10.1002/ ece3.3414.

Shinneman, D.J., Welty, J.L., Arkle, R.S., Pilliod, D.S., Glenn, N.F., McIlroy, S.K., and Halford, A.S., 2018, Fuels guide and database for intact and invaded big sagebrush (Artemisia tridentata) ecological sites-User manual: U.S. Geological Survey Data Series 1048, 9 p., https://doi.org/10.3133/ds1048.

Welty, J.L., and Jeffries, M.I., 2018, Western United States 30m heatload values: U.S. Geological Survey data release, https://doi.org/10.5066/F7WD3ZRD.

Welty, J.L., Arkle, R.S., Pilliod, D.S., 2017, Combined wildfire dataset for the United States and certain territories, 1870-2015: U.S. Geological Survey data release, https://doi.org/10.5066/F75H7F5M.

Welty, J.L., Shinneman, D.J., Arkle, R.S., Pilliod, D.S., Glenn, N.F., McIlroy, S.K., Halford, A.S., 2018, Fuels database for intact and invaded big sagebrush (Artemisia tridentata) ecological sites: U.S. Geological Survey data release, https://doi.org/10.5066/F7PC31P4.

\section{Future Fire in the Great Basin}

Understanding where, when, and why fires occur, how they may change in the future, and what their implications are for land management is fundamental to virtually all aspects of rangeland fire prevention, management, and restoration. USGS scientists are analyzing why fires occur and projecting where and when fire regimes may shift under expected future conditions. The researchers will evaluate some of the assumptions regarding altered fire regimes that are incorporated into the Fire and Invasives Assessment Tool (FIAT). This effort will determine the degree to which recurrent fire and invasive annual grass dominance (evidence of a fire-grass cycle) are associated with warm and dry soils and identify localities that have the strongest evidence for this relationship. This information can help managers prioritize their efforts within the extensive landscapes with warm and dry soils that lead to low resistance to invasion and resilience following disturbance.

\section{Contacts}

Douglas J. Shinneman, USGS Forest and Rangeland Ecosystem Science Center; dshinneman@usgs.gov; 208-426-5206

Matthew L. Brooks, USGS Western Ecological Research Center; mlbrooks@usgs.gov; 559-240-7622

\section{Publications}

Brooks, M.L., Matchett, J.R., Shinneman, D.J., and Coates, P.S., 2015, Fire patterns in the range of greater sage-grouse, 1984-2013-Implications for conservation and management: U.S. Geological Survey Open-File Report 2015-1167, 66 p., https://doi.org/10.3133/ofr20151167.

Chambers, J.C., Brooks, M.L., Germino, M.J., Maestas, J.D., Board, D.I., Jones, M.O., and Allred, B.W., 2019, Operationalizing resilience and resistance concepts to address invasive grass-fire cycles: Frontiers in Ecology and the Environment, v. 7 , article 185, 25 p., https://doi.org/10.3389/fevo.2019.00185.

Requena-Mullor, J.M., Maguire, K.C., Shinneman, D.J., and Caughlin, T.T., 2019, Integrating anthropogenic factors into regional-scale species distribution models-A novel application in the imperiled sagebrush biome: Global Change Biology, Early View article posted June 10, 2019, 15 p., https://doi.org/10.1111/gcb.14728.

Shinneman, D.J., 2019, Sagebrush_hurdle_model: U.S. Geological Survey software release, https://doi.org/10.5066/ P9NQNH41. 


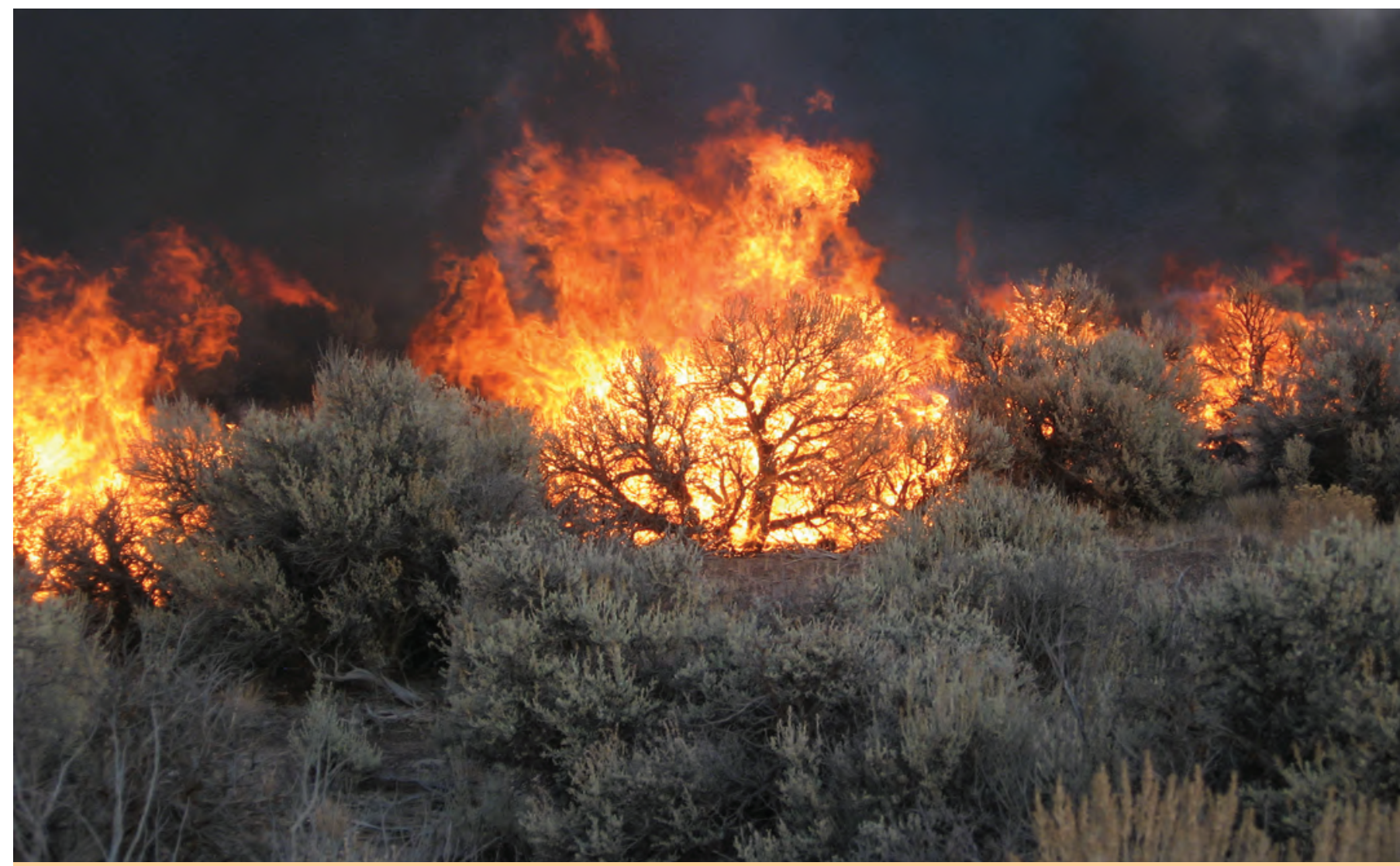

Fire in big sagebrush. Photograph by Scott Shaff, U.S. Geological Survey.

\section{Identifying the Effects of Reoccurring Fire on Sagebrush Ecosystems in the Northern Columbia Basin}

Most sagebrush ecosystems are adapted to relatively long fire return intervals, but frequent fires are becoming common across these landscapes. A decrease in the time between fires may delay ecosystem recovery and enhance the rate of conversion to nonnative species dominance. USGS research is identifying differences in successional trajectories across three burn frequencies in a sagebrush landscape in the northern portion of the Columbia Plateau in Washington State (fig. 1) by determining; (1) how key ecosystem vegetation characteristics, including fuels, differ across sagebrush sites that have burned once, twice, or three times over a 13-year period; (2) the impact of repeated fire on soil structure and function; and (3) how these characteristics at burned sites compare to nearby unburned sites. Investigating recovery using both vegetation and soils data can provide a comprehensive analysis on the effects of recurring fire on sagebrush ecosystems across the Columbia Basin.

\section{Contact}

Douglas J. Shinneman, USGS Forest and Rangeland Ecosystem Science Center; dshinneman@usgs.gov; 208-426-5206

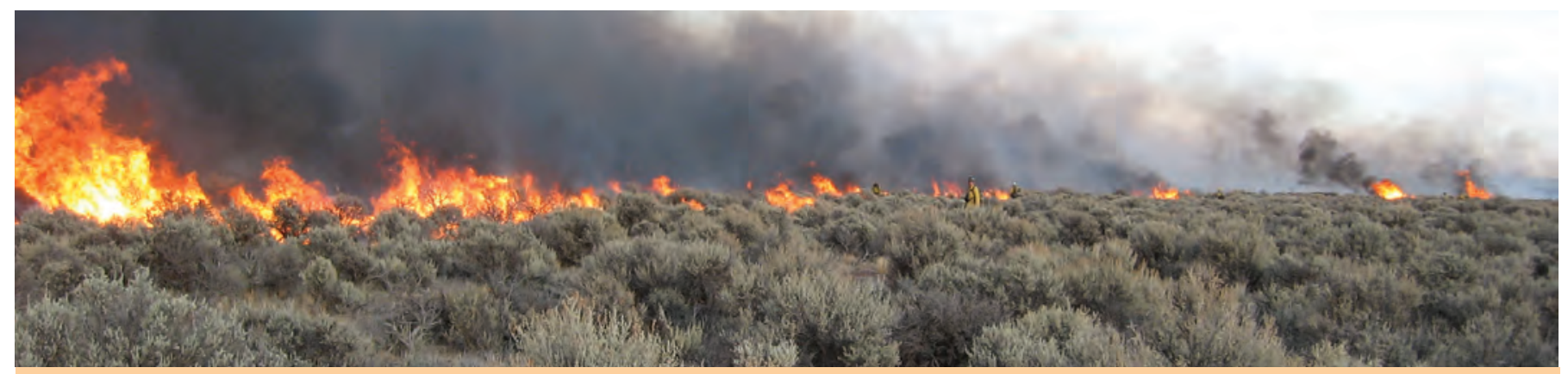

Controlled burn at Hart Mountain National Wildlife Refuge. Photograph by Scott Shaff, U.S. Geological Survey. 


\section{Using the Past and the Present To Understand Fire Ecology in the Range of the Gunnison Sage-Grouse}

Little is known about the role of fire in the sagebrush ecosystem within the range of the Gunnison sage-grouse

(Centrocercus minimus; fig. 1), and fire has been mostly absent from these systems in the 20th century, partially owing to active fire suppression. Tree-ring fire scars can provide unique insight into fire regimes prior to fire exclusion and have proven invaluable for managing forests and rangelands. Although fire scars are rare in sagebrush systems in the southwestern United States, USGS and university scientists have identified several sites with fire-scarred ponderosa pine (Pinus ponderosa) and Douglas-fir (Pseudotsuga menziesii) trees at sagebrush-forest ecotones in the upper Gunnison Basin. The researchers are using tree-ring fire-scars from these sites to reconstruct historical fire regime components, including fire frequency, extent, and seasonality and relationships to climate, over multiple centuries. They are also sampling and characterizing vegetation composition and structure from nearby sagebrush areas that have and have not experienced recent wildfire or prescribed burning. Findings of this study can inform fire and vegetation management on BLM and other lands.

\section{Contact}

Ellis Q. Margolis, USGS Fort Collins Science Center; emargolis@usgs.gov; 505-954-2251

\section{Effects of Large-Scale Wildfire on Habitat Use and Demography of Female Greater Sage-Grouse in Southeastern Oregon}

One of the key stressors for sage-grouse in the Great Basin is the conversion of sagebrush habitat to annual grasses through catastrophic wildfire. In August 2012, the Holloway Fire burned approximately 460,000 acres in highly productive sage-grouse habitat in northern Nevada and southeastern Oregon. USGS Oregon Cooperative Fish and Wildlife Research Unit, Oregon State University, and Oregon Department of Fish and Wildlife scientists initiated a long-term study in 2013 (now in its eighth consecutive year) using the Holloway Fire to address the initial, acute effects as well as the longer term, chronic effects of large-scale wildfire on the habitat use and demographics of female greater sage-grouse. Survival, reproductive ecology and success, and habitat selection are being monitored continuously to gain key information on the behavioral and demographic responses of female sage-grouse to a large-scale disturbance event and how those responses change relative to time since disturbance. In addition, the researchers recently initiated investigations into the thermal environment of sagebrush ecosystems relative to wildfire and the effect of these differences on sage-grouse nest site selection and nest survival. This information can provide mangers with information regarding postfire management and help identify potential options for maintaining sage-grouse populations.

\section{Contact}

Katie M. Dugger, USGS Oregon Cooperative Fish and Wildlife Research Unit; cdugger@usgs.gov; 541-737-2473

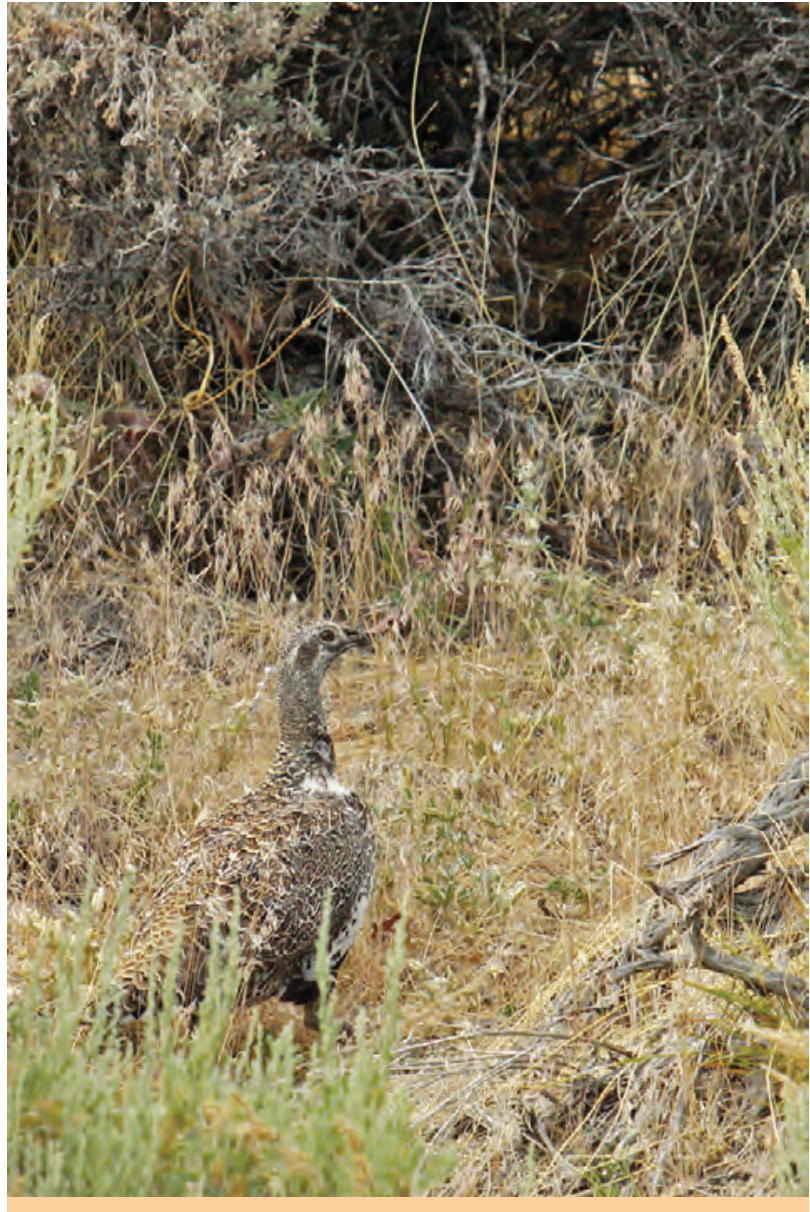

Female greater sage-grouse. Photograph by Tatiana Gettelman, U.S. Geological Survey. 


\section{Publications}

Anthony, C.R., Hagen, C.A., Dugger, K.M., and Elmore, R.D., 2020, The effects of fire on the thermal environment of sagebrush communities: Journal of Thermal Biology, v. 89, article 102488, https://doi.org/10.1016/j.jtherbio.2019.102488.

Foster, L.J., Dugger, K.M., Hagen, C.A., and Budeau, D.A., 2018, Potential effects of GPS transmitters on greater sage-grouse survival in a post-fire landscape: Wildlife Biology, v. 2018, no. 1, 5 p., https://doi.org/10.2981/wlb.00479.

Foster, L.J., Dugger, K.M., Hagen, C.A., and Budeau, D.A., 2019, Greater sage-grouse vital rates after wildfire: The Journal of Wildlife Management, v. 83, no. 1, p. 121-134, https://doi.org/10.1002/jwmg.21573.

\section{Wildfire Effects on Sage-Grouse-A Before and After Case Study}

In 2012, the Rush Fire burned more than 300,000 acres of priority sage-grouse habitat in northeastern California and northwestern Nevada. The burned area was considered the core of the remaining sage-grouse population in northern California. Beginning in fall 2014, the USGS implemented a study to compare postfire vital rates, resource utilization, and genetics to the same measures from the same area before the fire. Now in its fifth consecutive year, this ongoing study will increase ecological understanding of how sage-grouse respond demographically and spatially to wildfire and can help land managers better evaluate the efficacy of postfire actions designed to restore sagebrush habitat and ecosystem services.

\section{Contact}

Peter S. Coates, USGS Western Ecological Research Center; pcoates@usgs.gov; 530-669-5073

\section{Effects of Wildfire and Climate on Persistence of Greater Sage-Grouse}

Wildfire and climate change are frequently identified as important factors contributing to the decline of sage-grouse populations, yet fire regimes and climate patterns can vary substantially across broad geographic ranges. Using three decades of sagegrouse population counts, wildfire information, and climate data, USGS scientists linked long-term declines of sage-grouse to chronic effects of wildfire across the Great Basin. The analysis indicated that projected declines may be slowed or halted through fire suppression targeted at remaining areas of intact sagebrush with high densities of breeding sage-grouse. Ongoing research is determining how wildfire affects long-term sage-grouse population dynamics across their entire range and how variation in postfire recovery of sagebrush ecosystems modulates impacts of wildfire on sage-grouse population growth. Researchers are also using simulation analysis to better understand tradeoffs between restoration and suppression efforts in reducing long-term impacts to sage-grouse populations.

\section{Contacts}

Peter S. Coates, USGS Western Ecological Research Center; pcoates@usgs.gov; 530-669-5073

Cameron L. Aldridge, USGS Fort Collins Science Center; aldridgec@usgs.gov; 970-226-9433

David S. Pilliod, USGS Forest and Rangeland Ecosystem Science Center; dpilliod@usgs.gov; 208-426-5202

\section{Publication}

Coates, P.S., Ricca, M.A., Prochazka, B.G., Brooks, M.L., Doherty, K.E., Kroger, T., Blomberg, E.J., Hagen, C.A., and Casazza, M.L., 2016, Wildfire, climate, and invasive grass interactions negatively impact an indicator species by reshaping sagebrush ecosystems: Proceedings of the National Academy of Sciences of the United States of America, v. 113, no. 45, p. 12745-12750, https://doi.org/10.1073/pnas.1606898113. 


\section{Perennial Grass Response to Postfire Grazing Management in the Great Basin}

Perennial grasses are a vital component of a functioning sagebrush ecosystem and an important source of food for grazing cattle. In the event of a wildfire, burned perennial grasses need time to recover - but when are perennial grasses stable enough to accommodate grazing again? USGS scientists are investigating seasonal timing of grazing after fires and the length of grazing rest after fire to determine how these factors affect perennial grass recovery. In addition, this study is examining the length of grazing rest after postfire seeding to determine any impacts on seedling establishment and growth. Results can inform managers' recommendations for postfire livestock grazing when rehabilitation of sagebrush steppe habitat is the focus. Findings could also guide postfire grazing management on lands that provide critical sage-grouse habitat.

\section{Contact}

David A. Pyke, USGS Forest and Rangeland Ecosystem Science Center; david_a_pyke@usgs.gov; 541-750-0989

\section{Bunchgrass Maturity and Postfire Grazing}

Decisions on when and how to resume livestock grazing on the vast areas of rangeland burned each year are pivotal to ecological recovery and postfire restoration success, but the decisions are highly controversial and litigious because they have social, economic, and ecological impacts and a lack of scientifically based guidelines. In response to direct requests from managers, the USGS developed a series of experiments in the Northern Great Basin to evaluate the potential effects of different management options for resuming grazing following wildfire. The goals of these experiments are to determine the effects of resuming grazing 1, 2, or 3 years after postfire seeding in either spring or fall, and at different grazing levels. A key objective is to determine how bunchgrass "maturity" (that is, the stage at which bunchgrass provides resistance to invasive plants and resilience to future fires or drought) can be measured over large areas in short timeframes.

\section{Contact}

Matthew J. Germino, USGS Forest and Rangeland Ecosystem Science Center; mgermino@usgs.gov; 208-426-3353

\section{How Fire and Postfire Seeding Alter Pollinators in Sagebrush Habitat}

Wildfire and subsequent postfire restoration are common in western North America, yet information on how these events alter animal communities is generally lacking, especially for insect pollinators. USGS scientists compared insect pollinator assemblages in locations that burned 1 to 20 years prior to nearby unburned locations in sagebrush steppe habitats in southwestern Idaho. In some locations they also compared the diversity and abundance of pollinators in burned areas that were seeded after wildfire relative to burned areas that were not seeded. Other investigations examined the visitation of pollinators to small forb "islands" planted within burned areas to test this as an alternative strategy

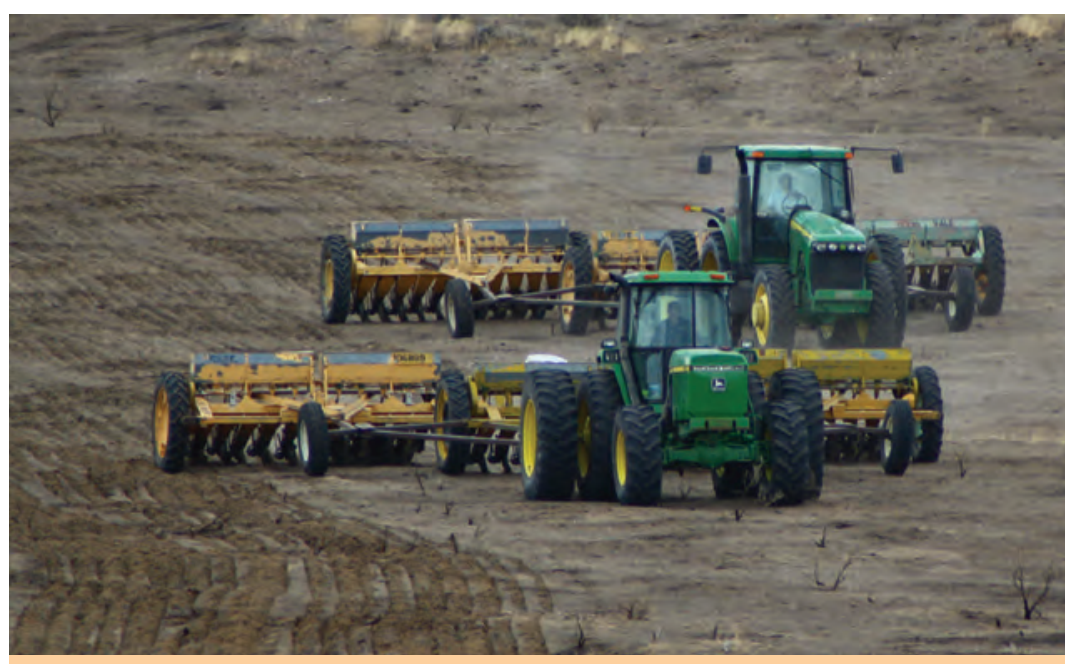

Drill seeding after the Soda Wildfire in southwestern Idaho. Photograph from Bureau of Land Management. or supplement to drill seeding. This combination of studies can reveal important information about forb-pollinator interactions and the effectiveness of restoring forbs to burned areas.

\section{Contact}

David S. Pilliod, USGS Forest and Rangeland Ecosystem Science Center; dpilliod@usgs.gov; 208-426-5202 


\section{Publication}

Rohde, A.T., Pilliod, D.S., and Novak, S.J., 2019, Insect communities in big sagebrush habitat are altered by wildfire and postfire restoration seeding: Insect Conservation and Diversity, v. 12, no. 3, p. 216-230, https://doi.org/10.1111/icad.12329.

\section{Pollinator Use of Forbs in the Soda Wildfire Area}

Pollinating insects are substantially declining across the United States, affecting native plants. USGS scientists are examining insect pollinator communities and forb-pollinator relationships at treatments across the area burned by the 2015 Soda Wildfire in southwestern Idaho and southeastern Oregon. Researchers are comparing pollinators in seeded burned areas to unburned areas outside the Soda Wildfire. Researchers are also comparing pollinator use of seeded forbs versus unseeded forbs, as well as native versus nonnative forbs. This research will contribute to the understanding of pollinators on public lands and inform pollinator conservation planning efforts.

\section{Contact}

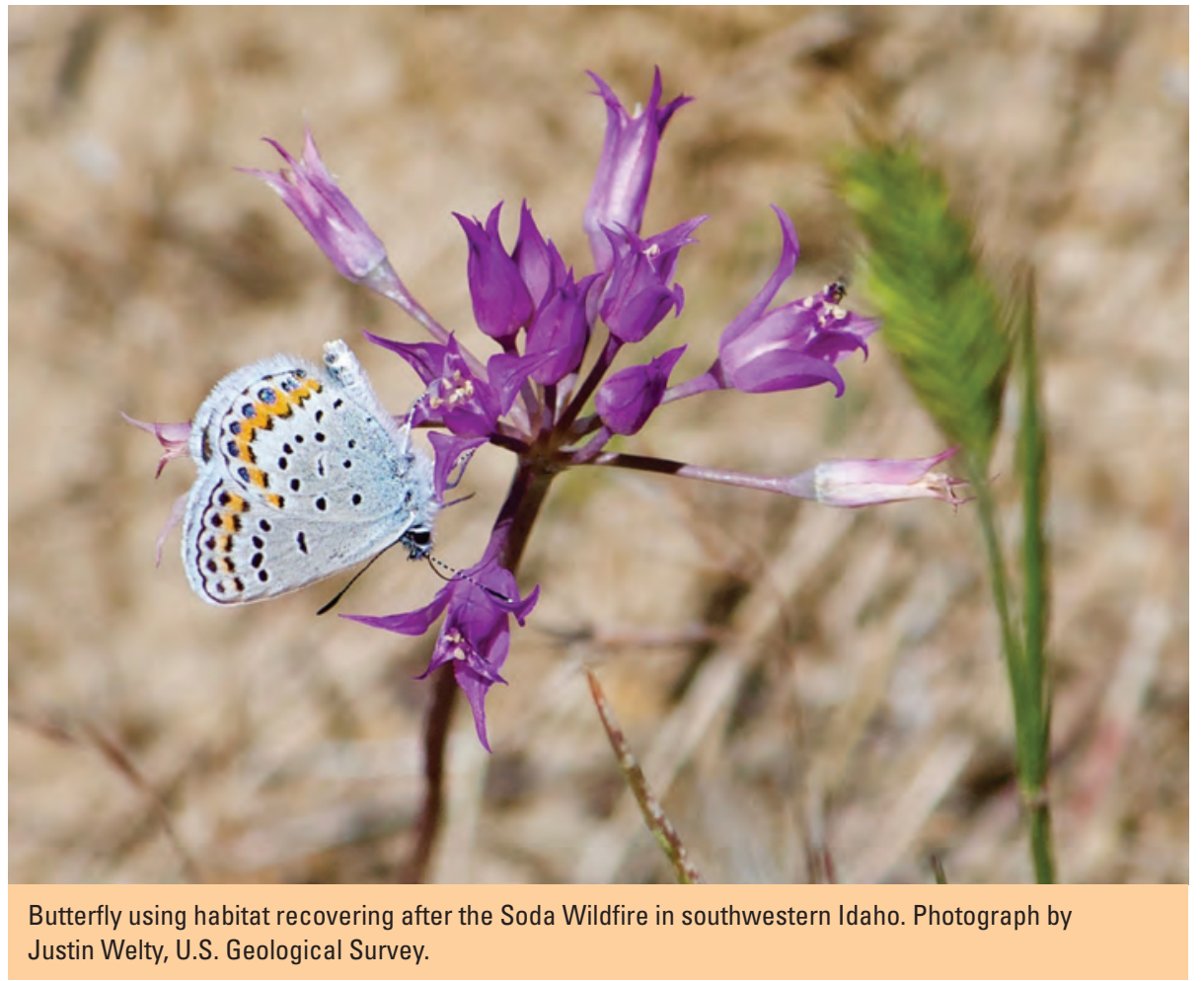

David S. Pilliod, USGS Forest and

Rangeland Ecosystem Science Center; dpilliod@usgs.gov; 208-426-5202

\section{Publication}

Sun, E.R., and Pilliod, D.S., 2018, Identification of bees in southwest Idaho-A guide for beginners: U.S. Geological Survey Circular 1448, 84 p., https://doi.org/10.3133/cir1448.

\section{Environmental and Fire Interactions in Northern Great Basin Vegetation Communities}

Management of sagebrush communities is complicated by the varied responses to the intensity and location of disturbances. USGS scientists, in collaboration with the BLM Assessment Inventory and Monitoring Program, are examining sites within sagebrush communities of the northern Great Basin to identify how the cover of native shrubs and grasses and invasive plants respond to disturbances, while also considering the influence of climate factors. BLM monitoring plots are found within landscapes of varying overall surface disturbance and within burned and unburned areas. Burned plots represent a range of fire severities and years since fire, allowing an examination of foliar cover, community composition, and recovery times following fires of mixed severity and overlap with the cumulative physical footprint of transportation, energy, and other surface disturbances. Identifying the factors leading to increased sagebrush community resistance and resilience can help mangers prioritize actions and identify sound management options.

\section{Contact}

David J.A. Wood, USGS Northern Rocky Mountain Science Center; dwood@usgs.gov; 406-896-5246 


\section{Publication}

Wood, D.J.A., Seipel, T., Irvine, K.M., Rew, L.J., and Stoy, P.C., 2019, Fire and development influences on sagebrush community plant groups across a climate gradient in northern Nevada: Ecosphere, v. 10, no. 12, article e02990, https://doi.org/10.1002/ecs2.2990.

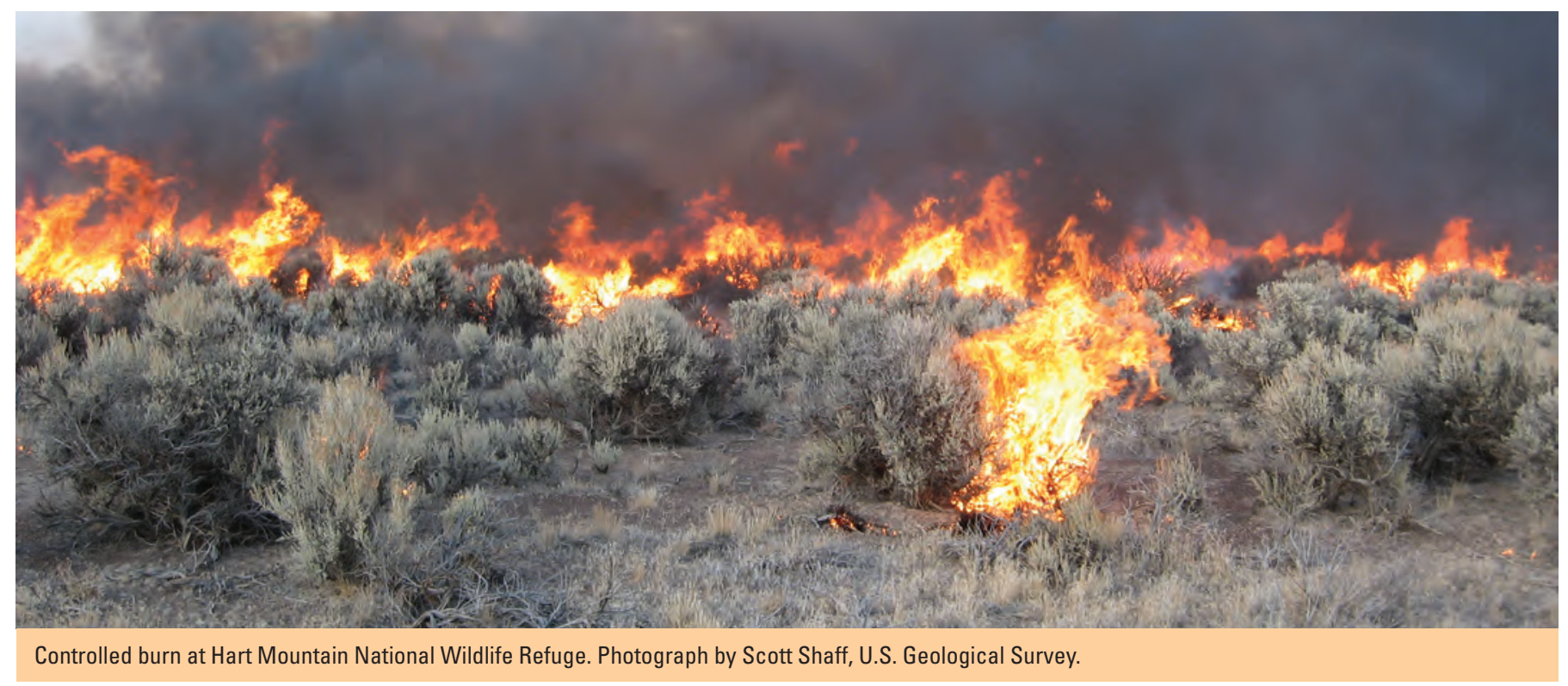

\section{Postfire Wind Erosion in Sagebrush Steppe}

Soil stability is a major concern for management of sagebrush-steppe landscapes, and wind erosion has emerged as a sporadic and seemingly overwhelming problem that signifies desertification. Wind erosion after large wildfires is greatly complicating ecosystem recovery and restoration and is creating human health and safety issues. USGS research evaluates the causes, consequences, and management implications of erosion, with the broader goal of developing predictive modeling capacity and decision support tools. This project will help inform managers during future ecoregional soil vulnerability assessments, soil stability monitoring, risk assessments for soil-disturbing or herbicide treatments, and adjustments to restoration techniques.

\section{Contact}

Matthew J. Germino, USGS Forest and Rangeland Ecosystem Science Center; mgermino@usgs.gov; 208-426-3353 


\section{Compiling and Summarizing Recent Science and Data on Invasive Annual Grasses for Land Managers}

The sagebrush biome across the Western United States is an imperiled landscape that is shrinking as a result of the interaction between annual invasive grasses and uncharacteristic wildfires. Three invasive annual grass species (cheatgrass, medusahead [Taeniatherum caput-medusae], and ventenata or Wiregrass [Ventenata spp.]) continue to spread across western sagebrush rangelands and can double the risk of wildfire while converting native sagebrush into nonnative invasive grasslands. Understanding the current and future threats of invasive annual grasses in the sagebrush ecosystem is a critical need for resource and wildfire management, biological planning, and conservation design for this imperiled ecosystem. The objectives of this project are to develop an annotated bibliography of recent, peer-reviewed literature for three invasive annual grass species of highest concern (cheatgrass, medusahead, and ventenata); review geospatial datasets available for these species, including data attributes; and provide an evaluation of the best uses of each product. An online version of the published annotated bibliographies will be searchable by topic and location and include links to all original publications and associated published, publicly available datasets. Comparisons of datasets will be based on criteria agreed upon by a stakeholder group composed of Federal, State, and nongovernmental organizations, and private end-users.

\section{Contacts}

Sarah K. Carter, USGS Fort Collins Science Center; skcarter@usgs.gov; 970-226-9355

Cameron L. Aldridge, USGS Fort Collins Science Center; aldridgec@usgs.gov; 970-226-9433

Steven E. Hanser, USGS Fort Collins Science Center; shanser@usgs.gov; 970-226-9309

Julie A. Heinrichs, Colorado State University, in cooperation with USGS Fort Collins Science Center; jheinrichs@usgs.gov; 970-226-9149

\section{Invasive Annual Grass Product Development for the Western United States}

Cheatgrass and other invasive annual grasses represent one of the single largest threats to the health and resilience of western rangelands. To address this challenge, the Western Governors Association (WGA)-appointed Western Invasive Species Council convened a cheatgrass working group to develop a new regional vision for invasive annual grass management across the Western United States. Foundational to implementing this new vision is the need for a spatial map of cheatgrass occurrence to guide strategic actions. The WGA cheatgrass working group developed a 30-meter base map of annual herbaceous (cheatgrass) cover to support a common spatial strategy for reducing the spread of invasive annual grasses across the Western United States. They leveraged three large-scale datasets to provide land managers with a spatial data layer estimating the recent extent (2016-2018) of invasive annual grasses across the Western rangelands. Annual herbaceous data inputs include the Rangeland Analysis Platform (Jones and others, 2018), U.S. Geological Survey (USGS) Harmonized Landsat and Sentinel-2 data (Pastick and others, 2020) and the USGS National Land Cover database (Rigge and others, 2020).

\section{Contacts}

Collin G. Homer (retired), USGS Earth Resources Observation and Science Center; homer@usgs.gov; 605-594-2714

Bruce K. Wylie, USGS Earth Resources Observation and Science Center; wylie@usgs.gov; 605-594-6078

\section{Publication}

Maestas, J., Jones, M., Pastick, N.J., Rigge, M.B., Wylie, B.K., Garner, L., Crist, M., Homer, C., Boyte, S., and Whitacre, B., 2020, Annual herbaceous cover across rangelands of the sagebrush biome: U.S. Geological Survey data release, https://doi.org/10.5066/P9VL3LD5. 


\section{Near-Real-Time Cheatgrass Mapping}

Mapping the invasion of sagebrush shrubland by cheatgrass in near realtime can help land managers understand the current distribution of cheatgrass and the potential risk for fire in the current year. USGS scientists have developed techniques that enable annual mapping of cheatgrass distributions. Maps have been made for the Great Basin and across Wyoming to provide a time series back to 2000. Researchers are now producing 250-meter-resolution cheatgrass distribution maps by late May for a current year to inform fire suppression activities and other management activities, such as application of weed-suppressive bacteria, targeted grazing, and other cheatgrass control measures. Map products at a higher resolution (30 meters) are under development and can help inform local-scale management efforts.

\section{Contact}

Bruce K. Wylie, USGS Earth Resources Observation and Science Center; wylie@usgs.gov; 605-594-6078

\section{Publications}

Boyte, S.P., and Wylie, B.K., 2016, Near-real-time cheatgrass percent cover in the northern Great Basin, USA, 2015:

Rangelands, v. 38, no. 5, p. 278-284, https://doi.org/10.1016/j.rala.2016.08.002.

Boyte, S.P., and Wylie, B.K., 2017, Near-real-time herbaceous annual cover in the sagebrush ecosystem (June 19, 2017):

U.S. Geological Survey data release, https://doi.org/10.5066/F7M32TNF.

Boyte, S.P., and Wylie, B.K., 2018, Near-real-time herbaceous annual cover in the sagebrush ecosystem, USA, July 2018 :

U.S. Geological Survey data release, https://doi.org/10.5066/P9RIV03D.

Boyte, S.P., and Wylie, B.K., 2019, Near-real-time herbaceous annual cover in the sagebrush ecosystem, USA, July 2019:

U.S. Geological Survey data release, https://doi.org/10.5066/P96PVZIF.

Boyte, S.P., Wylie, B.K., and Major, D.J., 2019, Validating a time series of annual grass percent cover in the sagebrush ecosystem: Rangeland Ecology \& Management, v. 72, no. 2, p. 347-359, https://doi.org/10.1016/j.rama.2018.09.004.

Boyte, S.P., Wylie, B.K., Rigge, M.B., and Dahal, D., 2018, Fusing MODIS with Landsat 8 data to downscale weekly normalized difference vegetation index estimates for central Great Basin rangelands, USA: GIScience \& Remote Sensing, v. 55, no. 3, p. 376-399, https://doi.org/10.1080/15481603.2017.1382065.

Dahal, D., Pastick, N.J., Parajuli, S., and Wylie, B.K., 2020, Early estimates of annual exotic herbaceous fractional cover in the sagebrush ecosystem, USA, May 2020: U.S. Geological Survey data release, https://doi.org/10.5066/P9ZZSX5Q.

Pastick, N.J., Wylie, B.K., and Wu, Z., 2018, Spatiotemporal analysis of Landsat-8 and Sentinel-2 data to support monitoring of dryland ecosystems: Remote Sensing, v. 10, no. 5, article 791, 15 p., https://doi.org/10.3390/rs10050791.
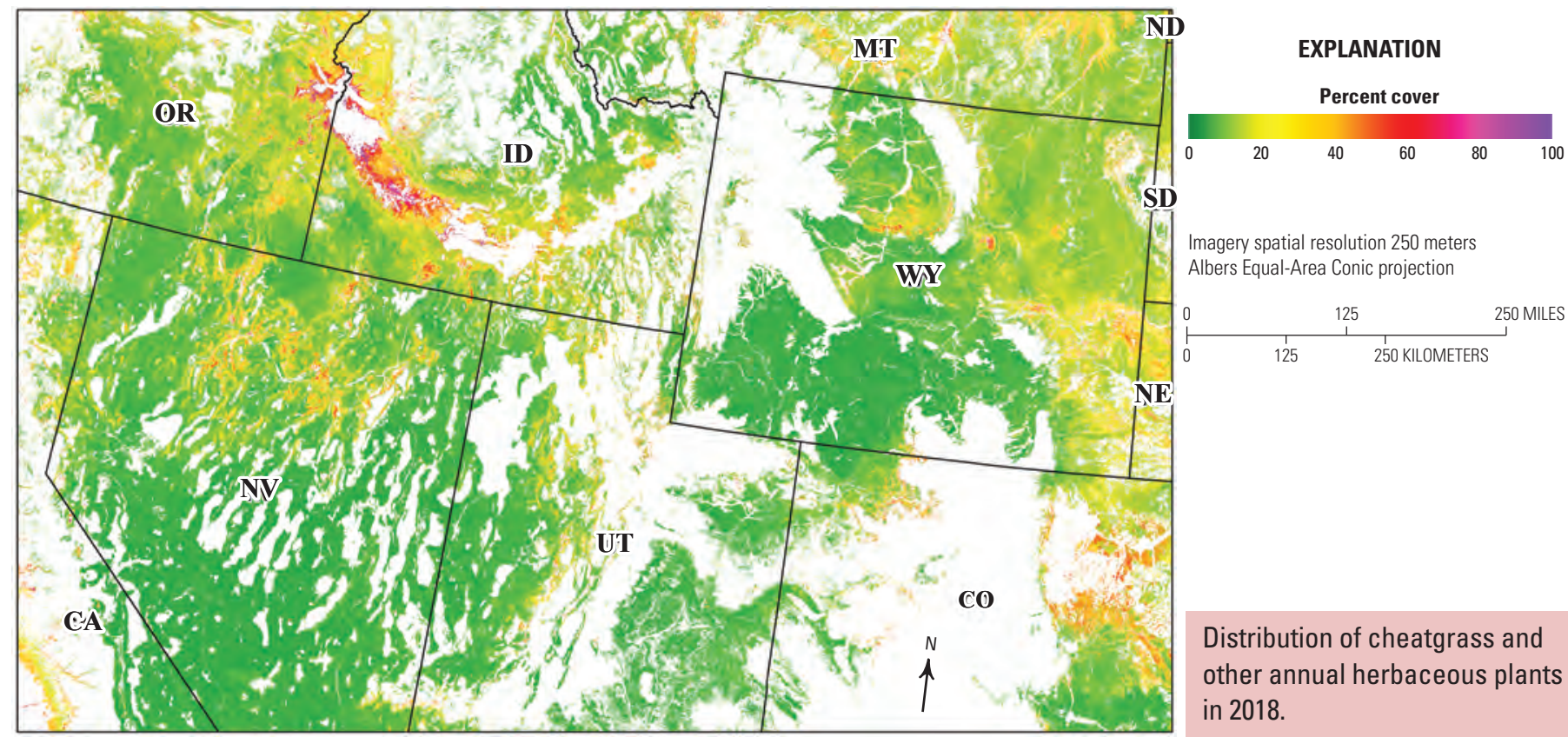

Distribution of cheatgrass and other annual herbaceous plants in 2018. 


\section{Sagebrush Ecosystem Management in Light of Sage-Grouse, Fire, and Invasive Species}

Scientists from the USGS, with Federal and State agency collaborators, have produced a strategic approach to help management agencies prioritize regional-scale management actions while maximizing conservation effectiveness. This approach was developed for conservation and restoration of sagebrush ecosystems and sage-grouse and focuses specifically on habitat threats caused by invasive annual grasses and altered fire regimes. The team used information about (1) factors that influence sagebrush ecosystem resilience to disturbance and resistance to invasive annual grasses and (2) the distribution, relative abundance, and persistence of sage-grouse populations to inform the development of management strategies at both landscape and site scales. The strategy approach and associated technical reports and publications may help managers determine the most effective management strategies based on an area's resilience to disturbance and resistance to nonnative invasive plants, particularly invasive annual grasses.

\section{Contact}

David A. Pyke, USGS Forest and Rangeland Ecosystem Science Center; david_a_pyke@usgs.gov; 541-750-0989

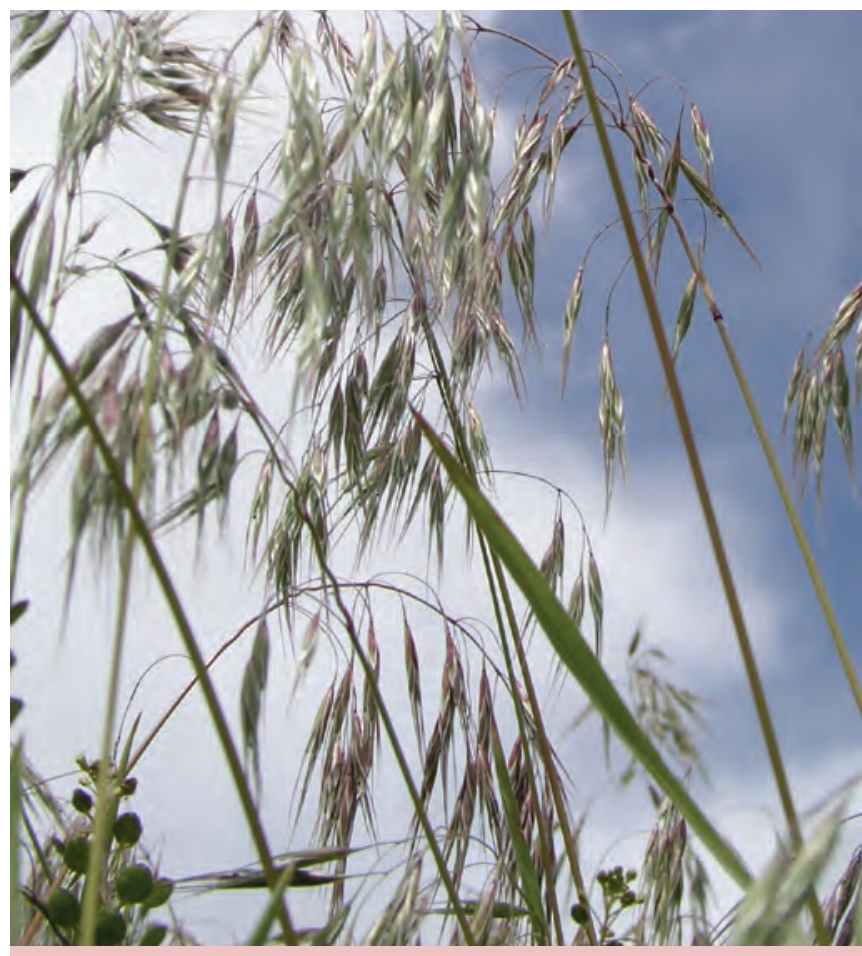

Cheatgrass. Photograph by Scott Shaff, U.S. Geological Survey.

\section{Publications}

Chambers, J.C., Beck, J.L., Bradford, J.B., Bybee, J., Campbell, S., Carlson, J., Christiansen, T.J., Clause, K.J., Collins, G., Crist, M.R., Dinkins, J.B., Doherty, K.E., Edwards, F., Espinosa, S., Griffin, K.A., Griffin, P., Haas, J.R., Hanser, S.E., Havlina, D.W., Henke, K.F., Hennig, J.D., Joyce, L.A., Kilkenny, F.M., Kulpa, S.M., Kurth, L.L., Maestas, J.D., Manning, M., Mayer, K.E., Mealor, B.A., McCarthy, C., Pellant, M., Perea, M.A., Prentice, K.L., Pyke, D.A., Wiechman, L.A., and Wuenschel, A., 2017, Science framework for conservation and restoration of the sagebrush biome-Linking the Department of the Interior's Integrated Rangeland Fire Management Strategy to long-term strategic conservation actions; Part 1. Science basis and applications: U.S. Department of Agriculture, Forest Service, Rocky Mountain Research Station, General Technical Report RMRS-GTR-360, 213 p., https://www.treesearch.fs.fed.us/pubs/53983.

Chambers, J.C., Beck, J.L., Campbell, S., Carlson, J., Christiansen, T.J., Clause, K.J., Dinkins, J.B., Doherty, K.E., Griffin, K.A., Havlina, D.W., Henke, K.F., Hennig, J.D., Kurth, L.L., Maestas, J.D., Manning, M., Mayer, K.E., Mealor, B.A., McCarthy, C., Perea, M.A., and Pyke, D.A., 2016, Using resilience and resistance concepts to manage threats to sagebrush ecosystems, Gunnison sage-grouse, and greater sage-grouse in their eastern range-A strategic multi-scale approach: U.S. Department of Agriculture, Forest Service, Rocky Mountain Research Station, General Technical Report RMRS-GTR-356, 143 p., https://www.treesearch.fs.fed.us/pubs/53201.

Chambers, J.C., Maestas, J.D., Pyke, D.A., Boyd, C.S., Pellant, M., and Wuenschel, A., 2017, Using resilience and resistance concepts to manage persistent threats to sagebrush ecosystems and greater sage-grouse: Rangeland Ecology \& Management, v. 70, no. 2, p. 149-164, https://doi.org/10.1016/j.rama.2016.08.005.

Chambers, J.C., Pyke, D.A., Maestas, J.D., Pellant, M., Boyd, C.S., Campbell, S.B., Espinoza, S., Havlina, D.W., Mayer, K.E., and Wuenschel, A., 2014, Using resistance and resilience concepts to reduce impacts of invasive annual grasses and altered fire regimes on the sagebrush ecosystem and greater sage-grouse-A strategic multi-scale approach: U.S. Department of Agriculture, Forest Service, Rocky Mountain Research Station, General Technical Report RMRS-GTR-326, 73 p., https://www.treesearch.fs.fed.us/pubs/46329.

Crist, M.R., Chambers, J.C., Phillips, S.L., Prentice, K.L., and Wiechman, L.A., eds., 2019, Science framework for conservation and restoration of the sagebrush biome - Linking the Department of the Interior's Integrated Rangeland Fire Management Strategy to long-term strategic conservation actions-Part 2. Management applications: U.S. Department of Forest Service, Rocky Mountain Research Station, General Technical Report RMRS-GTR-389, 237 p., https://doi.org/10.2737/ RMRS-GTR-389. 


\section{Spatial Variation in the Role of Climatic Extremes in Shaping Plant Invasions}

A broad-scale perspective is needed to link geographic variation in climate and disturbance to decisions on the ground regarding where to apply treatments aimed at limiting the impacts of invasions and restoring native plant composition. USGS scientists are conducting analyses to link the abundance of major plant invaders to climatic extremes, land use, and fire history. The researchers are determining how the drivers and limits of invader abundance vary among invasive species, between where species occur, and across the Great Basin and Mojave Desert. For example, they will examine if cheatgrass is likely to be limited by drought and temperature extremes, and whether those areas are vulnerable to red brome (Bromus rubens) invasion. The work can inform management by providing a nuanced spatial perspective on invasion risk for current and potential invaders.

\section{Contacts}

Helen R. Sofaer, USGS Pacific Island Ecosystems Research Center; hsofaer@usgs.gov; 808-985-6444

Catherine Jarnevich, USGS Fort Collins Science Center; jarnevichc@usgs.gov; 970-226-9439

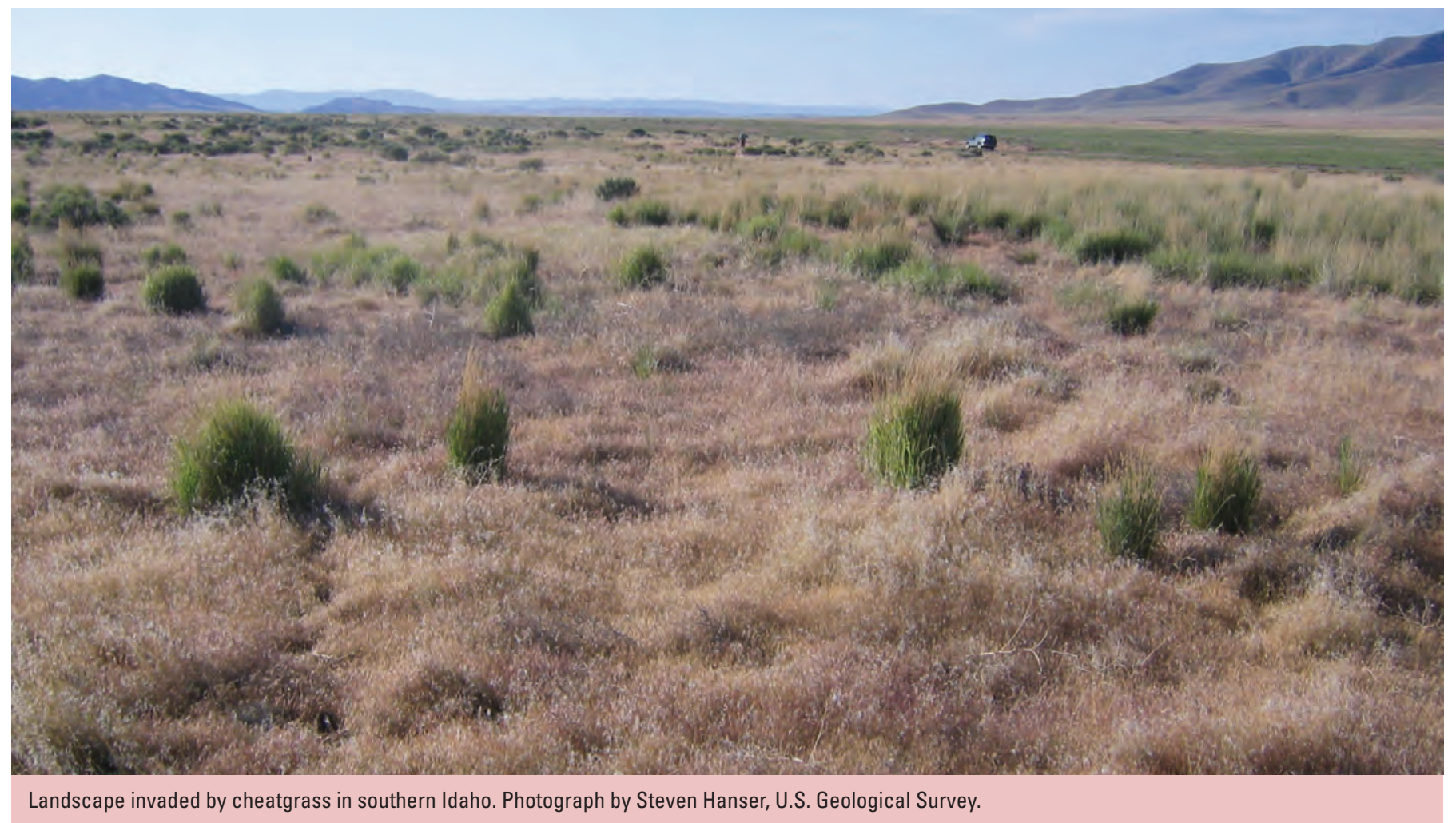

\section{Exotic Forbs in Disturbed Sagebrush Steppe}

Invasion by exotic tap-rooted forbs, such as spotted knapweed (Centaurea stoebe), leafy spurge (Euphorbia esula), thistles, or skeletonweed (Chondrilla juncea), stresses big sagebrush communities, especially at higher elevations. USGS scientists have completed nearly a decade of evaluation of plant community patterns that reveal inverse relationships of exotic forbs (or deeprooted native herbs) and big sagebrush. They are also examining the ecophysiological and hydrological mechanisms underlying the competition between these exotic and native species. These exotic forbs are often secondary invaders of areas already overtaken by exotic annual grasses. When present in the landscape, exotic forbs may increase appreciably following herbicide treatments aimed at controlling annual grasses. Studies are underway to evaluate the response of exotic forbs to postfire herbicide and other land treatments. This information is intended to help managers as they work to develop alternative control strategies for exotic forbs.

\section{Contact}

Matthew J. Germino, USGS Forest and Rangeland Ecosystem Science Center; mgermino@usgs.gov; 208-426-3353 


\section{Landscape-Scale Assessment of Emerging Techniques for Controlling Exotic Annual Grasses}

Invasive annual grasses such as cheatgrass and medusahead lead to increased fire frequency and loss of sagebrush steppe habitat and impede restoration of desirable perennials. Weed-suppressive bacteria (WSB) and herbicides such as imazapic are emerging tools for selectively reducing annual grasses, but field testing of their effectiveness is needed. USGS scientists and collaborators are comparing commercially available sources of WSB with and without different herbicides and other common postfire plant and soil treatments following fires that spanned southwestern Idaho in 2016. This research will determine if WSB are effective on target (exotic) and nontarget (native) species and will describe how to best apply WSB to help outreach specialists and land managers be best informed about the potential benefits and risks of WSB.

\section{Contact}

Matthew J. Germino, USGS Forest and Rangeland Ecosystem Science Center; mgermino@usgs.gov; 208-426-3353

\section{Publications}

Germino, M.J., and Lazarus, B.E., [in press], Weed-suppressive bacteria have no effect on exotic or native plants in sagebrush-steppe: Rangeland Ecology \& Management, https://doi.org/10.1016/j.rama.2019.10.004. [Available online November 27, 2019.]

Lazarus, B.E., and Germino, M.J., 2019, An experimental test of weed-suppressive bacteria effectiveness in rangelands in southwestern Idaho, 2016-18: U.S. Geological Survey Open-File Report 2019-1050, 19 p., https://doi.org/10.3133/ofr20191050.

Lazarus, B.E., Germino, M.J., Brabec, M.A., Peterson, L., Walker, R.N., and Moser, A.M., [in press], Post-fire managementscale trials of bacterial soil amendment MB906 show inconsistent control of invasive annual grasses: Rangeland Ecology \& Management, https://doi.org/10.1016/j.rama.2020.03.005. [Available online April 21, 2020.]

U.S. Geological Survey, 2020, Weed-suppressive bacteria-Testing a control measure for invasive grasses in the West: U.S. Geological Survey website, https://www.usgs.gov/centers/fresc/science/weed-suppressive-bacteria-testing-a-controlmeasure-invasive-grasses-west?qt-science_center_objects=0\#qt-science_center_objects. 


\section{Use of Cheatgrass-Suppressive Bacteria to Restore Sagebrush Steppe}

USGS scientists and colleagues are using weed-suppressive bacteria (WSB; Pseudomonas fluorescens, strain D7) in two case studies at the Hanford Reach National Monument to examine the potential for using successful WSB to attack invasive annual grasses (particularly cheatgrass) and leave native perennial plants intact. WSB was applied proactively to remaining sagebrush habitats that also have cheatgrass to potentially halt invasion and increase resistance to further invasion while retaining existing native sagebrush steppe plant communities. WSB was also applied to sagebrush understories, to help reduce cheatgrass fuel loads, which would result in reduced fire risk and rate of spread. If successful, WSB could be a cost-effective means to modify the seeding environment, boosting success in postfire rehabilitation projects through reducing annual grass competition with native seedlings while also minimizing the negative impacts to native plants that have been observed with the use of herbicides.

\section{Contact}

David A. Pyke, USGS Forest and Rangeland Ecosystem Science Center; david_a_pyke@usgs.gov; 541-750-0989

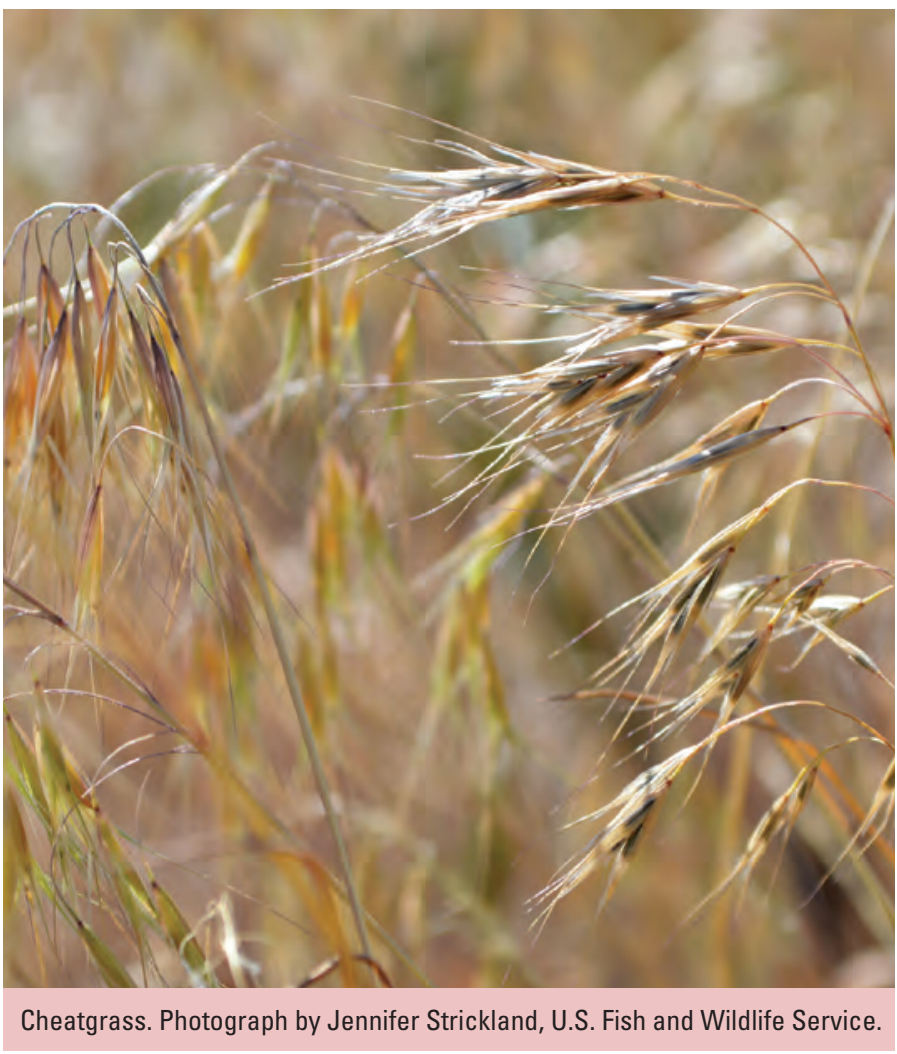

\section{Publications}

Pyke, D.A., Shaff, S.E., Gregg, M.A., and Conley, J.L., [in press], Weed-suppressive bacteria applied as a spray or seed mixture did not control Bromus tectorum: Rangeland Ecology \& Management, https://doi.org/10.1016/j.rama.2019.11.001. [Available online December 4, 2019.]

U.S. Geological Survey, 2020, Weed-suppressive bacteria-Testing a control measure for invasive grasses in the West: U.S. Geological Survey website, https://www.usgs.gov/centers/fresc/science/weed-suppressive-bacteria-testing-a-controlmeasure-invasive-grasses-west?qt-science_center_objects=0\#qt-science_center_objects.

\section{Evaluating a Novel Biopesticide for Controlling Exotic Annual Grasses Following Rangeland Wildfire}

Invasions by exotic annual grasses, most notably cheatgrass and medusahead, are unambiguous threats to rangelands in the Western United States, diminishing livestock productivity and increasing wildfire activity. In a new study, USGS scientists will test the effectiveness of a novel WSB known as MB906 combined with the herbicide imazapic on target weeds and nontarget native plants on over 1,000 acres in the Boise River Wildlife Management Area, Idaho. Study plots burned in the summer of 2016, and researchers will compare untreated, control areas to areas treated with WSB, imazapic, or the combination of WSB and imazapic. The objective is to determine if, when, and where spraying is effective for controlling exotic annual grasses.

\section{Contact}

Matthew J. Germino, USGS Forest and Rangeland Ecosystem Science Center; mgermino@usgs.gov; 208-426-3353

\section{Publications}

Applestein, C., Germino, M.J., and Fisk, M.R., 2018, Vegetative community response to landscape-scale post-fire herbicide (imazapic) application: Invasive Plant Science and Management, v. 11, no. 3, p. 127-135, https://doi.org/10.1017/inp.2018.18.

U.S. Geological Survey, 2020, Weed-suppressive bacteria-Testing a control measure for invasive grasses in the West:

U.S. Geological Survey website, https://www.usgs.gov/centers/fresc/science/weed-suppressive-bacteria-testing-a-controlmeasure-invasive-grasses-west?qt-science_center_objects=0\#qt-science_center_objects. 


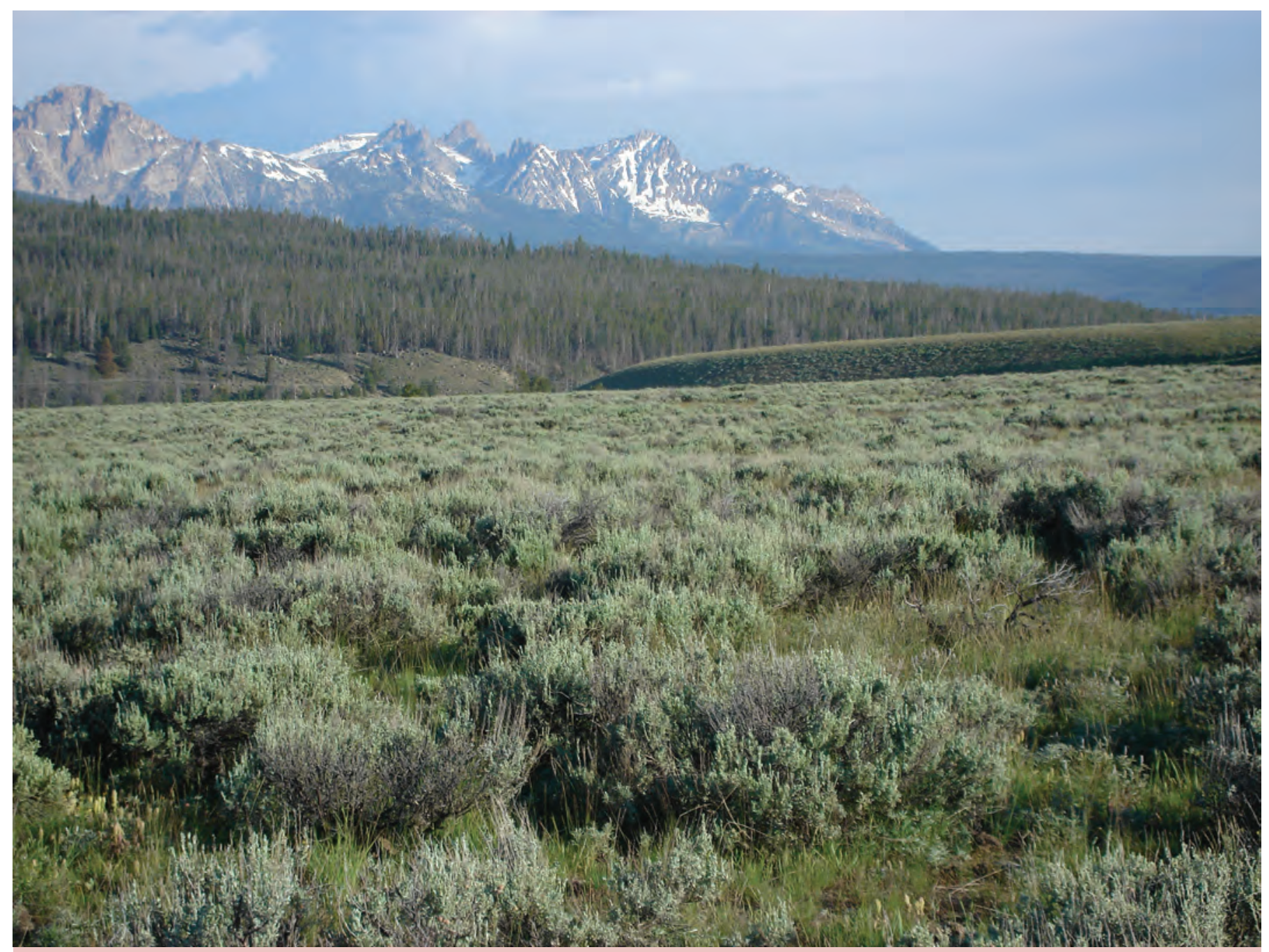

Sagebrush in the Sawtooth Valley, Idaho. Photograph by Steven Hanser, U.S. Geological Survey.

\section{Sweet Clover Encroachment and Effects on Sage-Grouse Habitat Quality}

Recent increases of exotic sweet clover (Melilotus officinalis) in sagebrush ecosystems are raising concerns for greater sage-grouse management. Little is known about sweet clover rates of encroachment or its influences on fire regimes, native vegetation, and wildlife behavior and distribution. USGS scientists are working with BLM to (1) develop sweet clover maps from Landsat imagery to describe its current and historic distribution, and (2) assess sage-grouse responses to sweet clover. Data sources for training Landsat-based models include (1) stereo and multispectral imagery acquired using drones at assessment, inventory, and monitoring (AIM) plots that included flowering sweet clover in 2019; (2) National Agriculture Imagery Program (NAIP) and commercial satellite imagery; and (3) AIM plot data. Researchers will use sweet clover maps with telemetry locations for sage-grouse to develop seasonal habitat models for Montana and the Dakotas. Maps of sweet clover distribution at high spatiotemporal resolutions can inform managers on invasion status, aid planning, and advance research on changes in ecosystem function and dynamics.

\section{Contact}

Aaron N. Johnston, USGS Northern Rocky Mountain Science Center; ajohnston@usgs.gov; 406-994-7158 


\section{Restoration}

Restoration of the sagebrush vegetation community following effects from stressors, including wildfire, invasive species, and numerous disturbance types, is important for maintaining the sagebrush ecosystem for wildlife and as healthy rangeland for grazing, recreation, and other uses by local communities. USGS scientists are conducting a range of studies, including assessing the efficiency and effectiveness of restoration actions and determining factors that increase their success. 


\section{Field of Sagebrush Dreams-Sage-Grouse Responses to Burns and Sagebrush Restoration in Fire- Affected Landscapes}

Fire can reduce sage-grouse habitat, diminish local and regional population sizes, and result in the fragmentation of sagegrouse populations. Research is needed to identify the best ways to restore sagebrush to support sage-grouse demography, persistence, and space use. To evaluate the efficacy of sagebrush restoration approaches that may create functional sage-grouse habitat in postfire landscapes, USGS and CSU scientists are (1) planting sagebrush in burned areas previously occupied by sage-grouse, (2) measuring sagebrush regrowth, (3) evaluating the use of revegetated areas by sage-grouse, and (4) predicting the success of sage-grouse using revegetated habitat. Using experiments with patch size, configuration, and proximity to edge of burn, the project aims to identify sage-grouse-focused sagebrush restoration approaches. This research also will predict times to sagebrush and sage-grouse recovery to help inform land and resource management decisions.

\section{Contacts}

Cameron L. Aldridge, USGS Fort Collins Science Center; aldridgec@usgs.gov; 970-226-9433

David A. Pyke, USGS Forest and Rangeland Ecosystem Science Center; david_a_pyke@usgs.gov; 541-750-0989

Peter S. Coates, USGS Western Ecological Research Center; pcoates@usgs.gov; 530-669-5073

Julie A. Heinrichs, Colorado State University, in cooperation with USGS Fort Collins Science Center; jheinrichs@usgs.gov; 970-226-9149

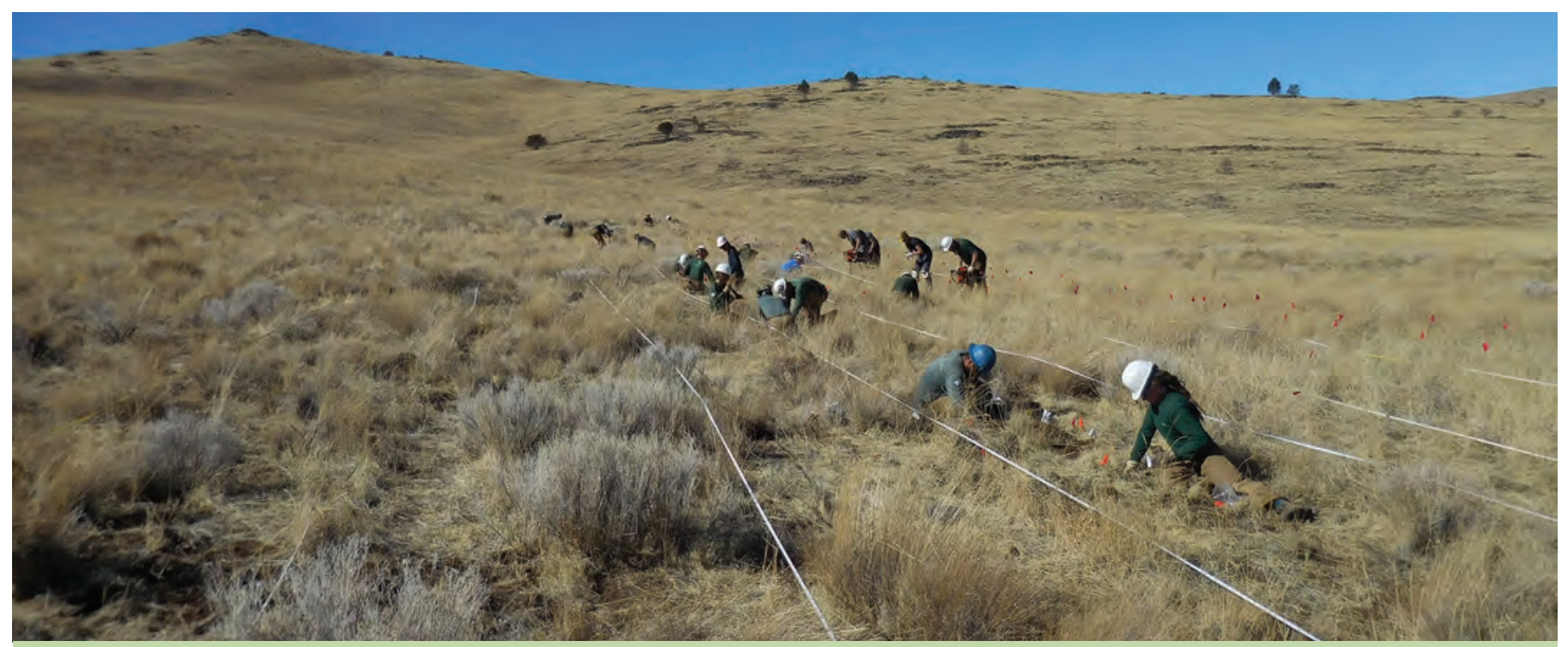

Field crew planting sagebrush seedlings in northeastern California. Photograph by David Pyke, U.S. Geological Survey.

\section{Restoration of Native Understory Plants in Degraded Sagebrush Steppe Ecosystems}

Sagebrush steppe that is resistant to annual grasses typically has herbaceous perennials between and under sagebrush and other shrubs. When fires burn these resistant communities, they may eliminate sagebrush temporarily, but understory plants may survive and compete with cheatgrass and shortly regain their codominance in the community. However, large expanses of sagebrush lands are now missing their herbaceous understory, owing to several factors, including inappropriate grazing, and are at risk of being dominated by annual grasses following fire. Current practice is to wait for fires to eliminate sagebrush before attempting restoration, but transplanting herbaceous understory plants into vacant gaps before the next fire may successfully increase resistance of these communities. USGS scientists are evaluating transplants and seeding for reintroducing native grasses and forbs into interspaces between shrubs to help inform future management efforts to improve sage-grouse habitat in sagebrush lands that are lacking native herbaceous plants.

\section{Contact}

David A. Pyke, USGS Forest and Rangeland Ecosystem Science Center; david_a_pyke@usgs.gov; 541-750-0989 


\section{Selecting the Right Seed for Restoration Success}

Sagebrush ecosystems are threatened by an increasing number of large wildfires because sagebrush cannot re-sprout after a burn and natural seedling establishment is limited. Land managers attempt to recolonize sagebrush by aerial or drill seeding burned areas. Seeds used in sagebrush ecosystem restoration and rehabilitation projects often are transferred across climate zones and hundreds of miles. USGS scientists are examining how seeds from different climates and with different genetic characteristics grow in variable climates and respond to traditional seeding treatments. They are determining how seeds of sagebrush and key native perennial species from different sources grow, survive, and respond to different temperature and precipitation patterns and to the planting methods managers traditionally employ. This information can help inform agency seed procurement and provide postfire rehabilitation specialists with the basic information needed to use "the right seed in the right place at the right time."

\section{Contact}

Matthew J. Germino, USGS Forest and Rangeland Ecosystem Science Center; mgermino@usgs.gov; 208-426-3353

\section{Publications}

Brabec, M.M., Germino, M.J., and Richardson, B.A., 2017, Climate adaption and post-fire restoration of a foundational perennial in cold desert-Insights from intraspecific variation in response to weather: Journal of Applied Ecology, v. 54, no. 1, p. 293-302, https://doi.org/10.1111/1365-2664.12679.

Chaney, L., Richardson, B.A., and Germino, M.J., 2017, Climate drives adaptive genetic responses associated with survival in big sagebrush (Artemisia tridentata): Evolutionary Applications, v. 10, no. 4, p. 313-322, https://doi.org/10.1111/eva.12440.

Germino, M.J., Moser, A.M., and Sands, A.R., 2019, Adaptive variation, including local adaptation, requires decades to become evident in common gardens: Ecological Applications, v. 29, no. 2, article e01842, 7 p., https://doi.org/10.1002/eap.1842.

Lazarus, B.E., Germino, M.J., and Richardson, B.A., 2019, Freezing resistance, safety margins, and survival vary among big sagebrush populations across the Western United States: American Journal of Botany, v. 106, no. 7, p. 922-934, https://doi.org/DOI:10.1002/ajb2.1320.

Richardson, B.A., Boyd, A.A., Tobaisson, T., and Germino, M.J., 2018, Spectrophotometry of Artemisia tridentata to quantitatively determine subspecies: Rangeland Ecology \& Management, v. 71, no. 1, p. 87-90, https://doi.org/10.1016/j.rama.2017.07.004.

Zaiats, A., Lazarus, B.E., Germino, M.J., Serpe, M.D., Richardson, B.A., Buerki, S., and Caughlin, T.T., 2020, Intraspecific variation in surface water uptake in a perennial desert shrub: Functional Ecology, v. 34, no. 6, p. 1170-1179, https://doi.org/10.1111/1365-2435.13546.

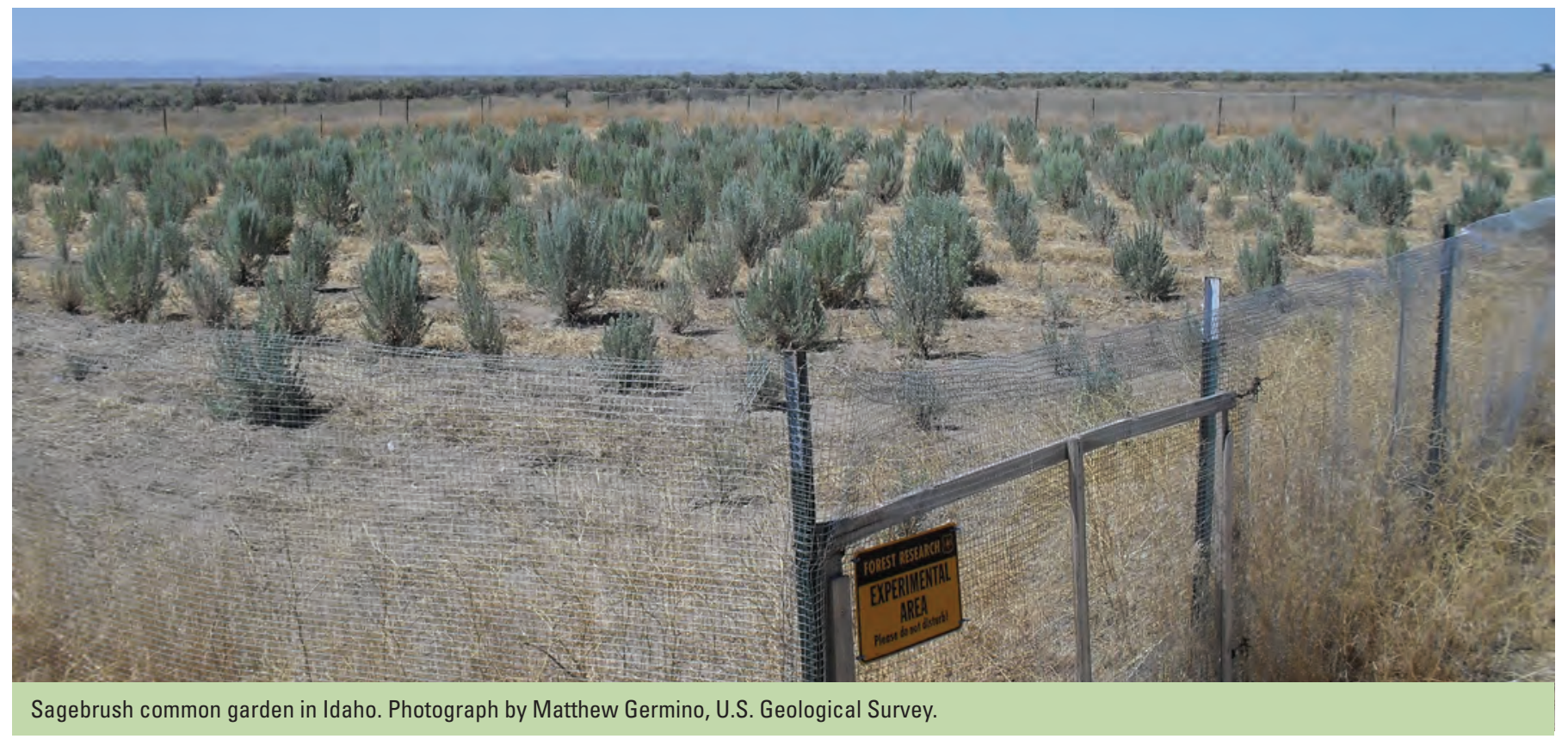




\section{SageSuccess Project-Sagebrush Restoration for Sage-Grouse}

The SageSuccess Project is a joint effort among the USGS, BLM, and FWS to examine the factors that contribute to establishment of big sagebrush across the range of sage-grouse and whether seeding and planting sagebrush ultimately creates high-quality sage-grouse habitat. Scientists will examine seedings and plantings completed between 1990 and 2013 to assess factors, including seed subspecies and source, climate, soil type and moisture, fire history, land use, and treatment implementation method. Where seed sources are known, researchers will assess the effects of seed transfer across geographic, elevation, and climate zones on seeding outcomes. This research is informing site-level management activities and continues to provide insights to help managers develop new practices or improvements of existing methods to restore sagebrush.

\section{Contacts}

David S. Pilliod, USGS Forest and Rangeland Ecosystem Science Center; dpilliod@usgs.gov; 208-426-5202

John B. Bradford, USGS Southwest Biological Science Center; jbradford@usgs.gov; 928-556-7300

\section{Publications}

Barnard, D.M., Germino, M.J., Arkle, R.S., Bradford, J.B., Duniway, M.C., Pilliod, D.S., Pyke, D.A., Shriver, R.K., and Welty, J.L., 2019, Soil characteristics are associated with gradients of big sagebrush canopy structure after disturbance: Ecosphere, v. 10, no. 6, article e02780, https://doi.org/10.1002/ecs2.2780.

Barnard, D.M., Germino, M.J., Pilliod, D.S., Arkle, R.S., Applestein, C., Davidson, B.E., and Fisk, M.R., 2019, Cannot see the random forest for the decision trees-Selecting predictive models for restoration ecology: Restoration Ecology, v. 27, no. 5, p. 1053-1063, https://doi.org/10.1111/rec.12938.

Germino, M.J., Barnard, D.M., Davidson, B.E., Arkle, R.S., Pilliod, D.S., Fisk, M.R., and Applestein, C., 2018, Thresholds and hotspots for shrub restoration following a heterogeneous megafire: Landscape Ecology, v. 33, p. 1177-1194, https://doi.org/10.1007/s10980-018-0662-8.

Shriver, R.K., Andrews, C.M., Arkle, R.S., Barnard, D.M., Duniway, M.C., Germino, M.J., Pilliod, D.S., Pyke, D.A., Welty, J.L., and Bradford, J.B., 2019, Transient population dynamics impede restoration and may promote ecosystem transformation after disturbance: Ecology Letters, v. 22, no. 9, p. 1357-1366, https://doi.org/10.1111/ele.13291.

Shriver, R.K., Andrews, C.M., Pilliod, D.S., Arkle, R.S., Welty, J.L., Germino, M.J., Duniway, M.C., Pyke, D.A., and Bradford, J.B., 2018, Adapting management to a changing world-Warm temperatures, dry soil, and interannual variability limit restoration success of a dominant woody shrub in temperate drylands: Global Change Biology, v. 24, no. 10, p. 4972-4982, https://doi.org/10.1111/gcb.14374.

\section{Assessing the Influence of Microsite Soil Characteristics on Sagebrush Restoration Success}

Fertile "islands" are important for germination, growth, and establishment of sagebrush and other plants in arid and semiarid environments because of the unique soil nutrients and microclimates they provide. In recently burned areas, these microsites are often associated with locations of former sagebrush plants. USGS scientists have observed big sagebrush seedling establishment in these fertile islands 1 year after fire, and sometimes these were the only locations where young sagebrush was thriving. The researchers are currently broadening the inference of these observations by sampling additional recently burned sites across the Great Basin to determine (1) whether this pattern holds, (2) what soil characteristics lead to this pattern, and (3) whether these soil characteristics could be reproduced by manipulating postfire soils in areas that had no prefire sagebrush. This work could help inform future big sagebrush seeding efforts.

\section{Contact}

David S. Pilliod, USGS Forest and Rangeland Ecosystem Science Center; dpilliod@usgs.gov; 208-426-5202 


\section{Soda Wildfire Response—Integrating Science into Adaptive Management}

The "Integrated Rangeland Fire Management Strategy" provides a comprehensive, science-based approach to enhance the conservation and restoration of the sagebrush steppe and to meet important economic, cultural, and social goals. The management response to the 2015 Soda Wildfire, which burned 285,000 acres of mostly sagebrush steppe in the northern Great Basin, is the first test of new guidelines outlined in the strategy. Managers used herbicide applications and planted or seeded desirable species to restore site resistance and resilience and habitats of sagebrush-obligate species. The USGS is leading the effort to monitor these vegetation treatments to (1) inform retreatment decisions, (2) determine when to allow resumption of grazing, (3) report on site recovery and treatment effectiveness, and (4) provide a comprehensive assessment of a major fire rehabilitation project in sagebrush steppe. Resulting data can be useful for testing theories about resistance and resilience, the role of bunchgrasses, exotic annual grass responses, sagebrush seed source effects, soil stability effects, and how management actionsparticularly iterative treatments - impact these variables.

\section{Contact}

Matthew J. Germino, USGS Forest and Rangeland Ecosystem Science Center; mgermino@usgs.gov; 208-426-3353

\section{Publications}

Applestein, C., Germino, M.J., and Fisk, M.R., 2018, Vegetative community response to landscape-scale post-fire herbicide (imazapic) application: Invasive Plant Science and Management, v. 11, no. 3, p. 127-135, https://doi.org/10.1017/inp.2018.18.

Applestein, C., Germino, M.J., Pilliod, D.S., Fisk, M.R., and Arkle, R.S., 2018, Appropriate sample sizes for monitoring burned pastures in sagebrush steppe-How many plots are enough, and can one size fit all?: Rangeland Ecology \& Management, v. 71, no. 6, p. 721-726, https://doi.org/10.1016/j.rama.2018.05.003.

Barnard, D.M., Germino, M.J., Pilliod, D.S., Arkle, R.S., Applestein, C., Davidson, B.E., and Fisk, M.R., 2019, Cannot see the random forest for the decision trees-Selecting predictive models for restoration ecology: Restoration Ecology, v. 27, no. 5, p. 1053-1063, https://doi.org/10.1111/rec.12938.

Davidson, B.E., Germino, M.J., Richardson, B., and Barnard, D.M., 2019, Landscape and organismal factors affecting sagebrush-seedling transplant survival after megafire restoration: Restoration Ecology, v. 27, no. 5, p. 1008-1020, https://doi.org/10.1111/rec.12940.

Germino, M.J., Barnard, D.M., Davidson, B.E., Arkle, R.S., Pilliod, D.S., Fisk, M.R., and Applestein, C., 2018, Thresholds and hotspots for shrub restoration following a heterogeneous megafire: Landscape Ecology, v. 33, p. 1177-1194, https://doi.org/10.1007/s10980-018-0662-8.

Germino, M.J., Fisk, M.R., and Applestein, C., 2019, Bunchgrass root abundances and their relationship to resistance and resilience of a burned shrub-steppe landscape: Rangeland Ecology \& Management, v. 72, no. 5, p. 783-790, https://doi.org/10.1016/j.rama.2019.04.001.

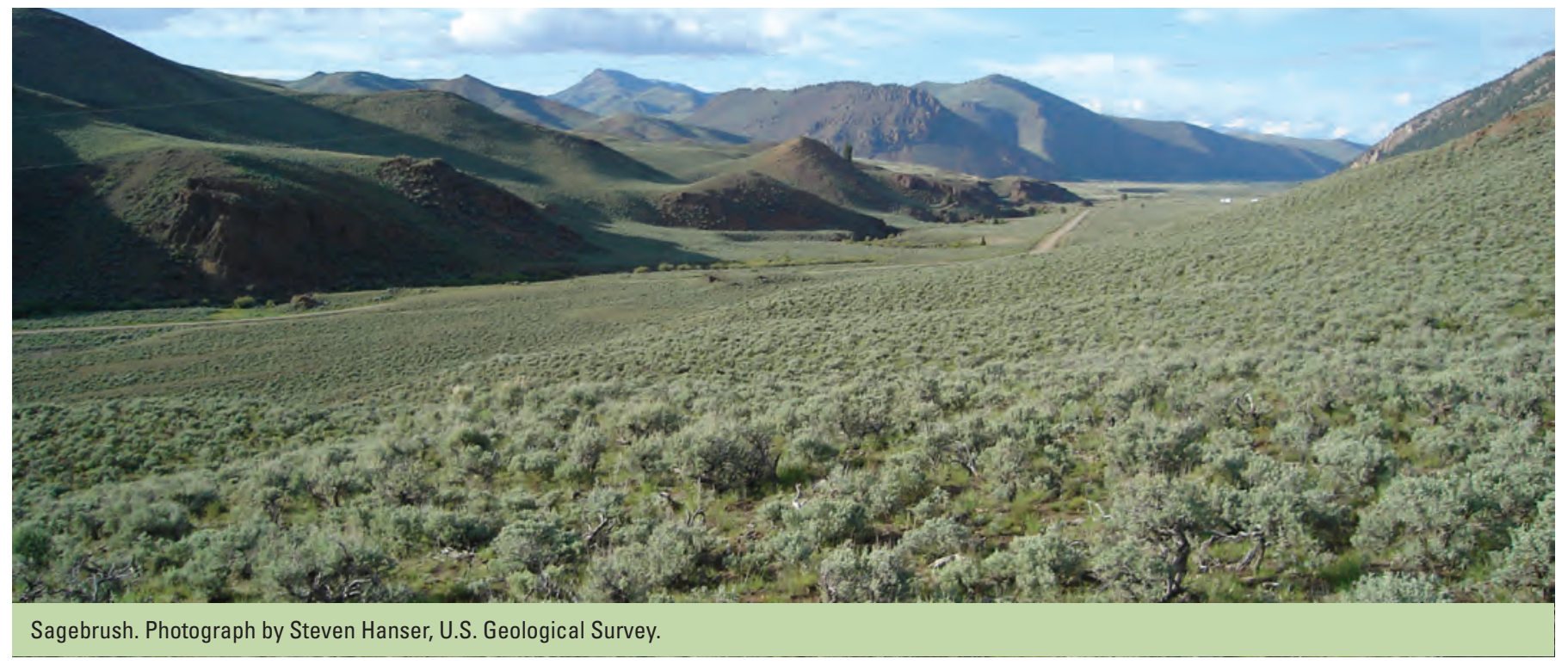




\section{Postfire Sagebrush Growth}

Establishment and growth of big sagebrush after fire are critical components of restoration efforts in the Great Basin; however, these ecological processes often occur over several decades and thus are difficult to document. In the northern Great Basin, a number of postfire restoration vegetation surveys conducted between 5 and 25 years ago provide an opportunity to revisit and measure these vegetation characteristics. The goal of these remeasurement surveys is to quantify how growth of big sagebrush after fire influences habitat of greater sage-grouse through changes in density, cover, and height. USGS researchers are also assessing how sagebrush growth influences cover of exotic annuals, especially cheatgrass, and native forbs. Comparisons between growth rates of seeded and planted (that is, nursery-raised seedlings) will be made. Results may assist managers in determining the length of time and environmental conditions required for sagebrush establishment to meet sage-grouse habitat guidelines.

\section{Contact}

David S. Pilliod, USGS Forest and Rangeland Ecosystem Science Center; dpilliod@usgs.gov; 208-426-5202

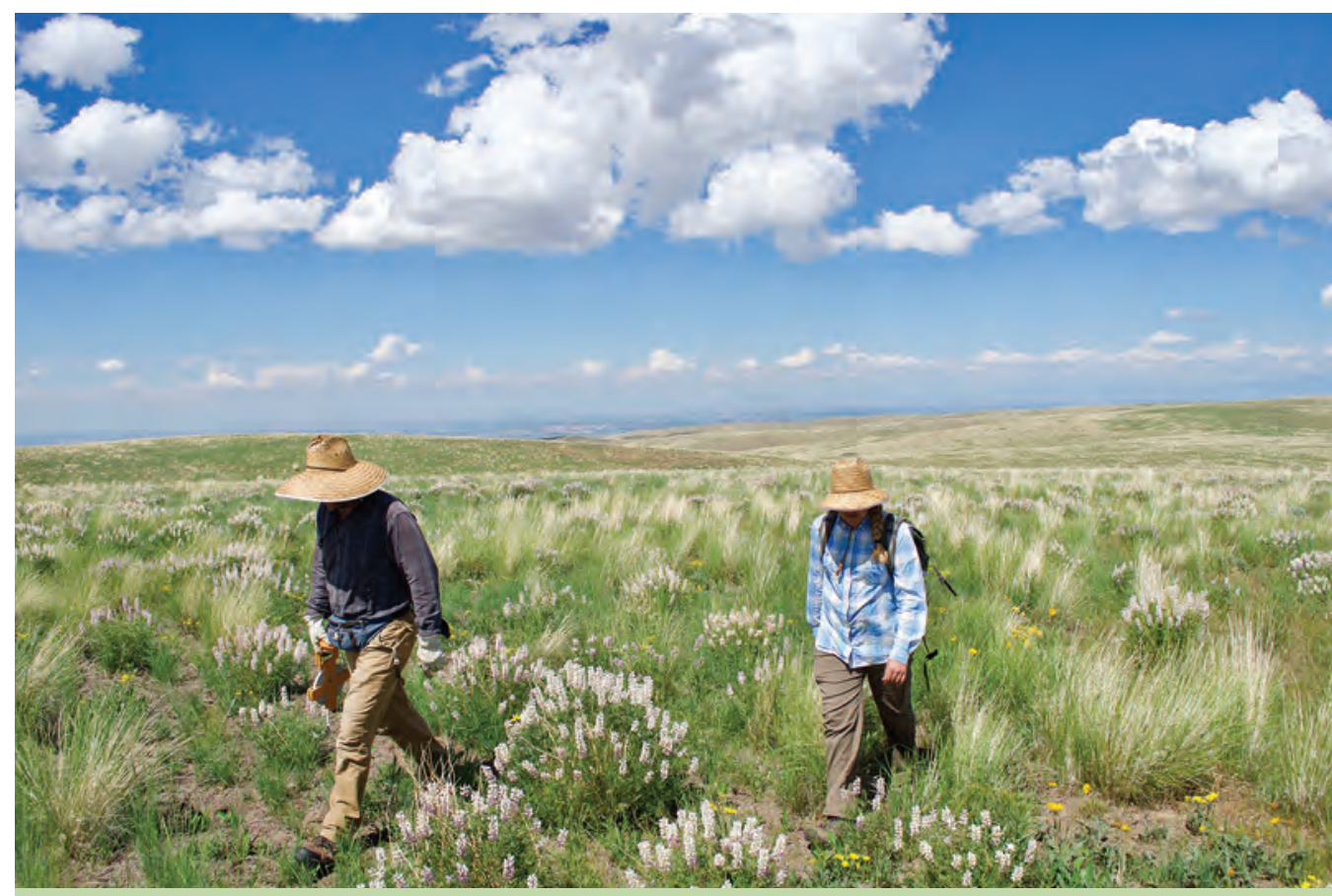

USGS biologists in the area burned by the Soda Wildfire in 2015. Photograph by Justin Welty, U.S. Geological Survey.

\section{Land Treatment Digital Library}

The BLM actively manages vegetation on millions of acres of public rangelands in the United States. In 2017, the USGS and BLM published a compilation of more than 75 years of records of those vegetation management actions - or land treatments - into a centralized, spatially explicit database called the Land Treatment Digital Library (LTDL), which can be accessed at https://ltdl.wr.usgs.gov. In this publication, the researchers summarized data from more than 9,000 treatments in the Great Basin to highlight the scope and scale of information in the LTDL. The authors discussed how this information can be used for adaptive management and ecological research, including evaluating responses of communities and ecosystems to natural and human caused disturbance. Information in the LTDL can help land managers evaluate past treatments and improve future restoration actions.

\section{Contact}

David S. Pilliod, USGS Forest and Rangeland Ecosystem Science Center; dpilliod@usgs.gov; 208-426-5202

\section{Publications}

Carter, S.K., Pilliod, D.S., Haby, T., Prentice, K.L., Aldridge, C.L., Anderson, P.J., Bowen, Z.H., Bradford, J.B., Cushman, S.A., DeVivo, J.C., Duniway, M.C., Hathaway, R.S., Nelson, L., Schultz, C.A., Schuster, R.M., Trammell, E.J., and Weltzin, J.F., 2020, Bridging the research-management gap-Landscape science in practice on public lands in the Western United States: Landscape Ecology, v. 35, p. 545-560, https://doi.org/10.1007/s10980-020-00970-5.

Copeland, S.M., Munson, S.M., Pilliod, D.S., Welty, J.L., Bradford, J.B., and Butterfield, B.J., 2018, Long-term trends in restoration and associated land treatments in the southwestern United States: Restoration Ecology, v. 26, no. 2, p. 311-322, https://doi.org/10.1111/rec.12574. 
Pilliod, D.S., Welty, J.L., and Toevs, G.R., 2017, Seventy-five years of vegetation treatments on public rangelands in the Great Basin of North America: Rangelands, v. 39, no. 1, p. 1-9, https://doi.org/10.1016/j.rala.2016.12.001.

Pilliod, D.S., and Welty, J.L., 2013, Land Treatment Digital Library: U.S. Geological Survey Data Series 806, https://doi.org/10.3133/ds806.

\section{Land Treatment Exploration Tool}

The LTDL houses information on nearly 50,000 land treatments in the Western United States. The BLM and the USGS have developed a decision support and planning tool (https://chsapps.usgs.gov/apps/land-treatment-exploration-tool/) that enables users to upload a proposed treatment area during the planning phase of a project to identify past treatments that have occurred in the surrounding area or that share similar characteristics, such as treatment types, ecological sites, seed mixes, or other factors. When queried, the tool returns both nearby treatments and treatments within a larger range that match one or more specific search attributes specified by the user. Users can then tap into this information to assess what worked where and why, and potentially network with other personnel who implemented these treatments. Ultimately, this tool aids in planning future land treatments and implementing adaptive management strategies for improved likelihood of success for future treatments.

\section{Contact}

David S. Pilliod, USGS Forest and Rangeland Ecosystem Science Center; dpilliod@usgs.gov; 208-426-5202

\section{Publication}

Pilliod, D.S., Welty, J.L., Jeffries, M.I., Schueck, L.S., and Zarriello, T.J., 2018, Land treatment exploration tool (rev. 1.1, October 2018): U.S. Geological Survey Fact Sheet 2018-3042, 2 p., https://doi.org/10.3133/fs20183042.

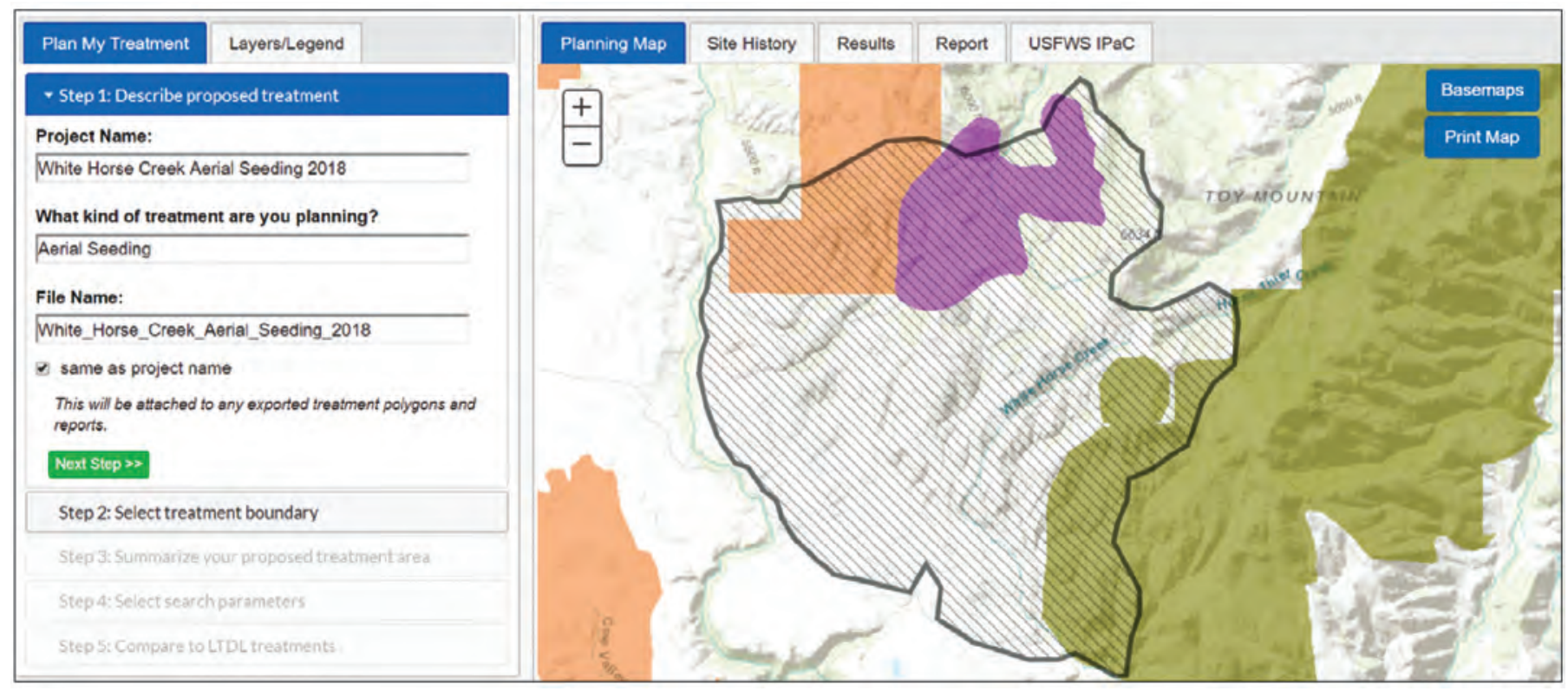

Example of the interactive map interface in the land treatment planning tool. 


\section{Decision Support for Conservation and Restoration Efforts in the Sagebrush Biome}

The DOI, USDA, and State agencies share common management goals for sagebrush ecosystems, including improving the capacity to manage for resistance to invasive species or resilience to disturbance to achieve long-term conservation and restoration objectives. USGS scientists along with Federal and State partners have developed a core set of data and models that provide an analytical backbone to support planning needs in the sagebrush biome. These data and models have been added to a web-based tool that make the data and derived products associated with the "Science Framework for Conservation and Restoration of the Sagebrush Biome" (Chambers and others, 2017) available and usable by a wide audience. This "Conservation and Restoration Strategy Tool" is now available and can be accessed at https://doi.sciencebase.gov/cnr/. Key functions of the web tool include (1) spatial data discovery and exploration; (2) summarization and reporting of data by predefined geographic units at different scales; and (3) summarization and reporting of data by user-defined areas of interest. This work is capitalizing on previous and ongoing research projects that are focused on large landscape conservation.

\section{Contacts}

Steven E. Hanser, USGS Fort Collins Science Center; shanser@usgs.gov; 970-226-9309

Zachary H. Bowen, USGS Ecosystems Mission Areas; bowenz@usgs.gov; 970-226-9218

\section{Optimization of Management Actions for Restoration Success and Wildlife Populations}

Sagebrush ecosystems continue to undergo degradation in response to multiple factors. Adaptive management decision making for these ecosystems often involves considering how best to restore sagebrush systems to support the differing needs of declining species, such as sage-grouse, Brewer's sparrow, and mule deer. These decisions can be aided by information about which management practices can be implemented for multiple species and the costs of different restoration efforts. USGS researchers in collaboration with the Wyoming Landscape Conservation Initiative and other partners are developing a statistically based prioritization tool that could help agencies (1) identify where and what type of restoration efforts are most likely to be successful in achieving vegetation recovery to predisturbance conditions (within economic constraints), (2) assess which of those restoration treatments provide the greatest benefits to wildlife populations, and (3) optimize the choice of regional restoration strategies to meet multispecies management objectives using an ecological optimization framework. Initial models indicate that focusing efforts in habitats most likely to recover are more likely to be successful and could be applied to benefit a diverse suite of species of conservation concern.

\section{Contacts}

Cameron L. Aldridge, USGS Fort Collins Science Center; aldridgec@usgs.gov; 970-226-9433

Adrian P. Monroe, USGS Fort Collins Science Center; amonroe@usgs.gov; 970-226-9122

\section{Interpreting Indicators of Rangeland Health}

Qualitative assessments of rangeland health using observable indicators help managers make informed land management decisions and communicate findings with the public. The USGS and other Federal agencies have jointly developed a system in which 17 indicators are used to gauge three attributes of rangeland health—soil and site stability, hydrology, and biology—and created a monitoring protocol for managers to assess the functional status of rangelands and provide early warnings of resource problems. Recent revisions to the protocol reflect changes learned through 13 years of teaching and applying previous versions. The evaluation is used widely by the BLM, the Natural Resources Conservation Service (NRCS), and many private ranchers and rangeland consultants.

\section{Contact}

David A. Pyke, USGS Forest and Rangeland Ecosystem Science Center; david_a_pyke@usgs.gov; 541-750-0989

\section{Publications}

Herrick, J.E., Shaver, P., Pyke, D.A., Pellant, M., Toledo, D., and Lepak, N., 2019, A strategy for defining the reference for land health and degradation assessments: Ecological Indicators, v. 97, p. 225-230, https://doi.org/10.1016/j.ecolind.2018.06.065. 
Pellant, M., Shaver, P.L., Pyke, D.A., Herrick, J.E., Lepak, N., Riegel, G., Kachergis, E., Newingham, B.A., Toledo, D., and Busby, F.E., 2020, Interpreting indicators of rangeland health, version 5: Denver, Colo., U.S. Department of the Interior, Bureau of Land Management, National Operations Center, Technical Reference 1734-6, 203 p. [Also available at https:// www.landscapetoolbox.org/manuals/iirhv5/.]

\section{Effectiveness of Layering Treatments in the "Multiple Intervention" Response to Wildfire in Sagebrush Steppe}

Improving postfire treatments to decrease exotic annuals and increase perennial plants is a priority science need for managers. Postfire treatments typically entail multiple interventions, such as herbicide or seeding applications, which can have reinforcing or canceling effects on treatment success. There is little science to inform decisions on how to order and time different treatments following fire, however. USGS scientists are conducting research on the 285,000 acres burned by the 2015 Soda Wildfire in southwestern Idaho to determine how different sequences of seeding and herbicide can be optimized to reduce exotics and increase perennials, and how treatment effects are modulated by postfire grazing resumption. This project can help managers determine how treatments can be best phased to optimize postfire restoration outcomes.

\section{Contact}

Matthew J. Germino, USGS Forest and Rangeland Ecosystem Science Center; mgermino@usgs.gov; 208-426-3353
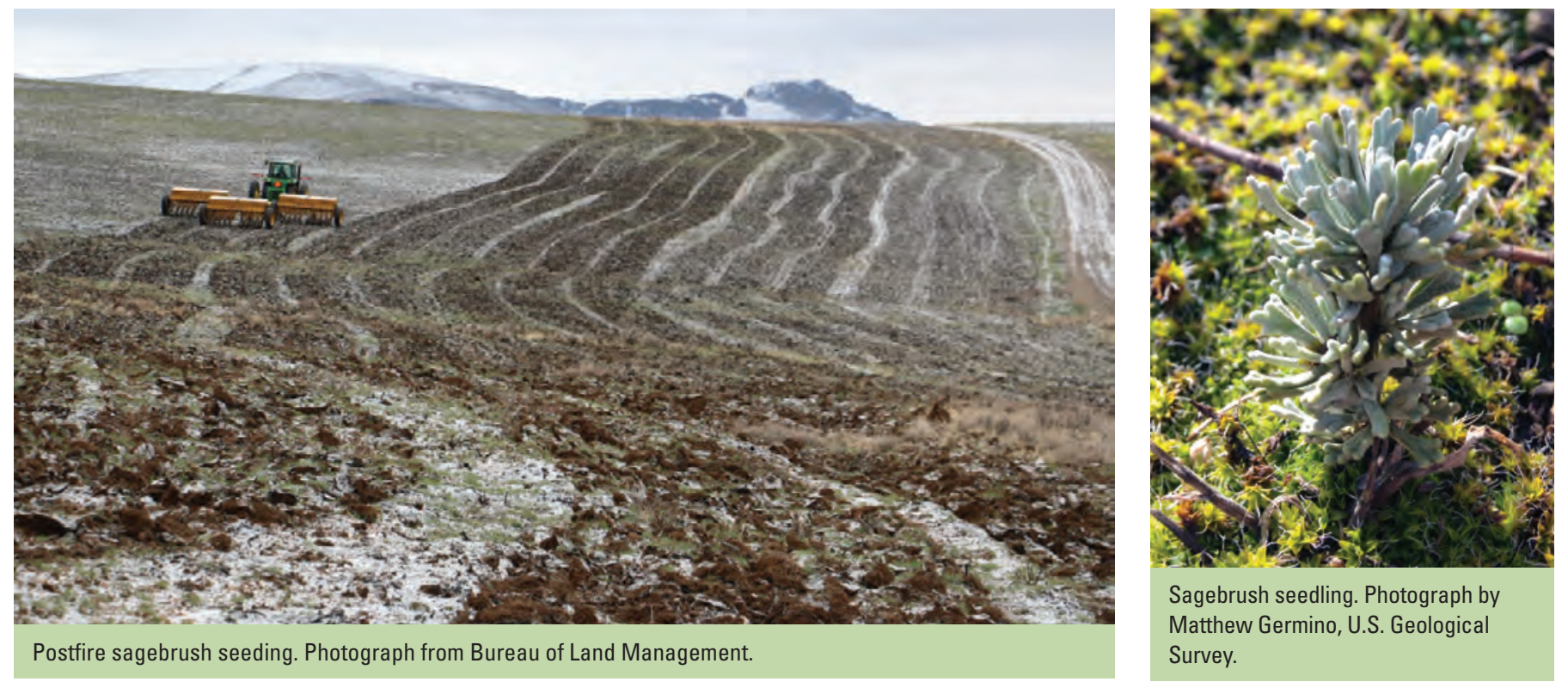

\section{Phasing Herbicide, Drill Seeding, and Grazing Resumption in Postfire Sagebrush Steppe}

Postfire management interventions in the sagebrush steppe often combine treatments, such as applying herbicides to reduce exotic annuals or seeding desirable perennials. Phasing these various treatment types in different postfire years may optimize effects and increase a site's ability to withstand impacts of resuming livestock grazing. USGS scientists are measuring how vegetation responds to phasing of land management actions — specifically herbicide spraying, drill seeding, and resumption of grazing - in the first few years following wildfire in sagebrush steppe. They will assess the relative abundance of exotic annual and desirable perennial grasses with respect to different sequences of seeding and spraying, and determine how treatments contribute to a site's resistance, resilience, and ability to withstand grazing. This research will provide information to rangeland managers about if and how to combine and phase herbicide and seeding treatments.

\section{Contact}

Matthew J. Germino, USGS Forest and Rangeland Ecosystem Science Center; mgermino@usgs.gov; 208-426-3353 


\section{Publication}

Applestein, C., Germino, M.J., and Fisk, M.R., 2018, Vegetative community response to landscape-scale post-fire herbicide

(imazapic) application: Invasive Plant Science and Management, v. 11, no. 3, p. 127-135, https://doi.org/10.1017/inp.2018.18.

\section{Experimental Tests of Management Options for Improving Outplanting Success of Big Sagebrush}

Methods for increasing success of seeded or planted sagebrush can be useful to land managers. USGS scientists are performing experimental tests of methods for improving sagebrush outplanting success, including the use of wind shelters, wattles, cluster plantings, landscape and topography strategies, and treatments of herb layers. Outcomes of this study may help provide managers with new methods for improving establishment of sagebrush in restoration treatments.

\section{Contact}

Matthew J. Germino, USGS Forest and Rangeland Ecosystem Science Center; mgermino@usgs.gov; 208-426-3353

\section{The Biggest Bang for the Buck-Cost-Effective Vegetation Treatment Outcomes Across Drylands of the Western United States}

Restoration and rehabilitation treatments that manipulate vegetation can be expensive to implement but are infrequently evaluated to determine whether spending more improves intended outcomes. In collaboration with the Utah Department of Natural Resources, USGS scientists assessed commonly implemented vegetation treatments and costs relative to their outcomes across sagebrush shrublands and pinyon-juniper woodlands across Utah (fig. 2). Results suggest there are differential benefits of treatments aimed at reducing wildfire risk, improving wildlife habitat and forage, and reducing erosion. Given the growing need and costs of land management actions, this project helps inform the importance of specifying treatment budgets and objectives, coupled with effectiveness monitoring, to improve future efforts.

\section{Contact}

Seth M. Munson, USGS Southwest Biological Science Center; smunson@usgs.gov; 928-556-7301

$\boldsymbol{A}$

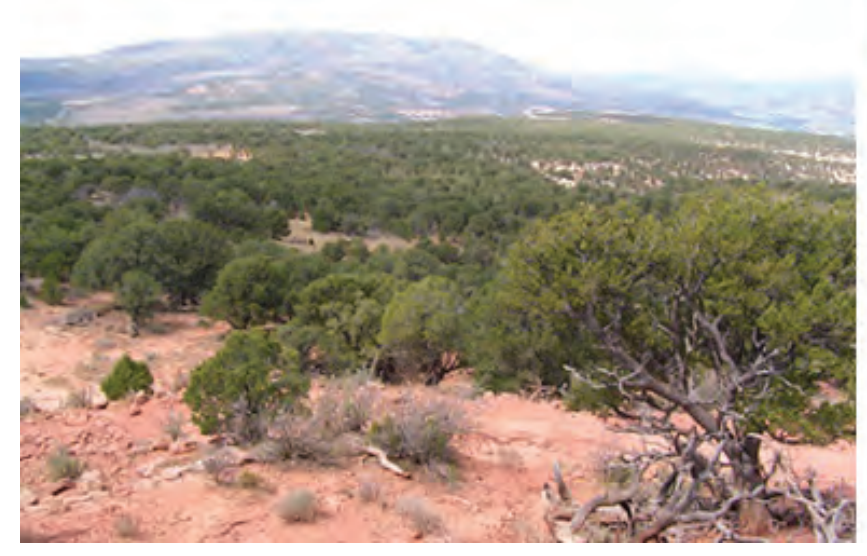

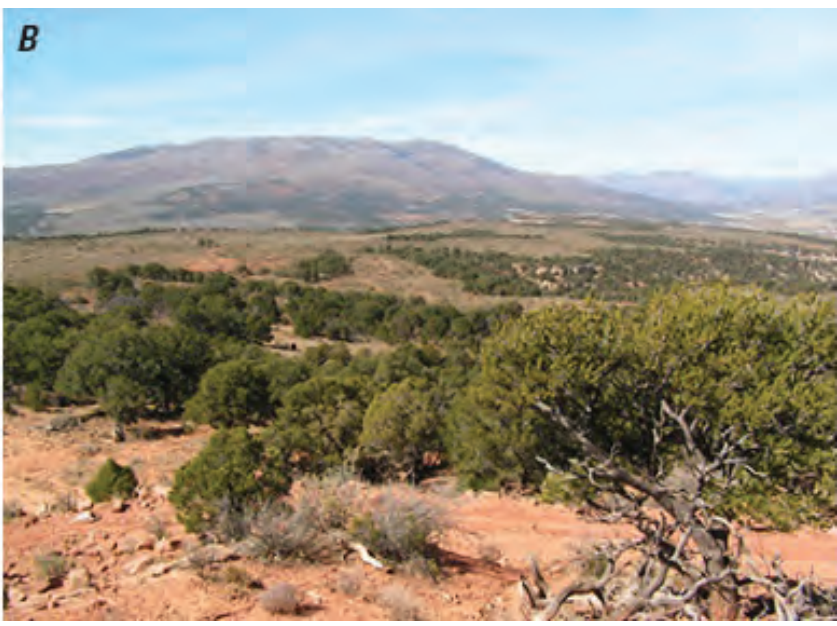

Figure 2. Photographs of Blacktail Ridge in northeastern Utah showing the areas of rangeland where juniper has been removed. $A$, the area on September, 13, 2007, before being treated to reduce juniper and increase sagebrush and perennial grass cover. $B$, the area on 0 ctober 11,2007 , after being treated, showing regrowth of sagebrush and perennial grasses. Treatments to remove woody plants that have increased in density are common across drylands in the Western United States and globally, yet little is known about the cost-effectiveness of such treatments. Photographs courtesy of Utah's Watershed Restoration Initiative (http://wri.utah.gov). 


\section{Publication}

Munson, S.M., Yackulic, E.O., Bair, L.S., Copeland, S.M., and Gunnell K.L., in press, The biggest bang for the buck-Costeffective vegetation treatment outcomes across drylands of the Western United States: Ecological Applications, early view of online version of record posted August 2, 2020, https://doi.org/10.1002/eap.2151.

\section{Community Composition and Restoration of Biological Soil Crusts of Nevada's Sagebrush Shrublands}

Biological soil crusts often exist in spaces between arid and semiarid plants and can improve soil stability, hydrology, nutrient cycling, and potentially the resistance of plant communities to invasive annual grasses. The USGS is leading a study to examine the extent of biological soil crusts in Nevada's sagebrush shrublands and some of the potential factors influencing the absence of crusts across the sagebrush ecosystem. Researchers will use existing data to find ecological sites with the potential to support biological soil crusts. Objectives include determining how soil properties, climate, livestock use, and fire affect the community composition of biological soil crusts. Results of this study may show how crusts respond to disturbances and the ecological factors that influence these important biological communities. This knowledge can help inform future management actions to maintain biological soil crusts in the sagebrush ecosystem.

\section{Contact}

David A. Pyke, USGS Forest and Rangeland Ecosystem Science Center; david_a_pyke@usgs.gov; 541-750-0989

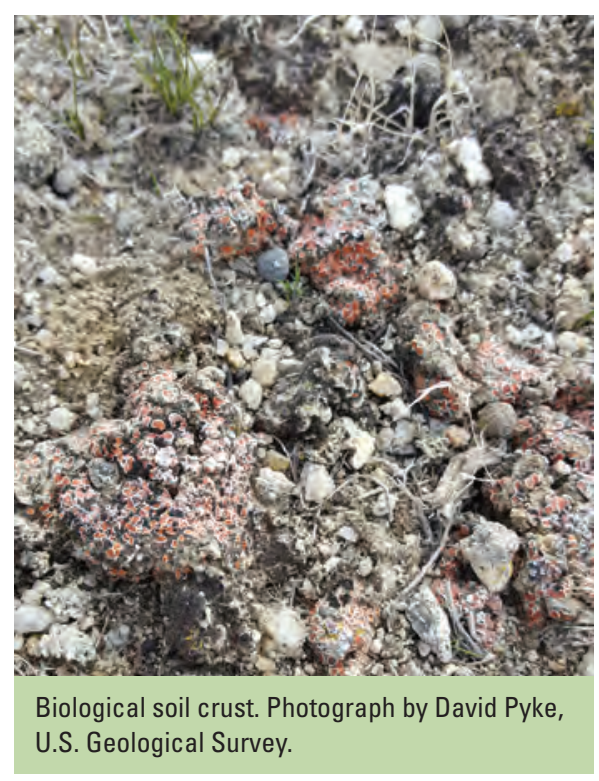

\section{Publications}

Antoninka, A., Faist, A., Rodriguez-Caballero, E., Young, K.E., Chaudhary, V.B., Condon, L.A., and Pyke, D.A, in press, Biological soil crusts in ecological restoration-Emerging research and perspectives: Restoration Ecology, early view of online version of record posted May 14, 2020, https://doi.org/10.1111/rec.13201.

Condon, L.A., and Pyke, D.A., 2016, Filling the interspace-Restoring arid land mosses—source populations, organic matter, and overwintering govern success: Ecology and Evolution, v. 6, no. 21, p. 7623-7632, https://doi.org/10.1002/ece3.2448.

Condon, L.A., and Pyke, D.A., 2018a, Fire and grazing influence site resistance to Bromus tectorum through their effects on shrub, bunchgrass and biocrust communities in the Great Basin (USA): Ecosystems, v. 21, no. 7, p. 1416-1431, https://doi.org/10.1007/s10021-018-0230-8.

Condon, L.A., and Pyke, D.A., 2018b, Resiliency of biological soil crusts and vascular plants varies among morphogroups with disturbance intensity: Plant and Soil, v. 433, no. 1-2, p. 271-287, https://doi.org/10.1007/s11104-018-3838-8.

Condon, L.A., and Pyke, D.A., 2020, Components and predictors of biological soil crusts vary at the regional versus plant community scales: Frontiers in Ecology and Evolution, v. 7, January, article 449, https://doi.org/10.3389/fevo.2019.00449.

Condon, L.A., Pietrasiak, N., Rosentreter, R., and Pyke, D.A., in press, Passive restoration of vegetation and biological soil crusts following 80 years of exclusion from grazing across the Great Basin: Restoration Ecology, early view of online version of record posted August 5, 2019, https://doi.org/10.1111/rec.13021. 


\section{Holding Their Ground—Does Biological Soil Crust Restoration Enhance the Germination of Native Plants and Reduce Soil Degradation?}

In the Great Basin, soil erosion on burned slopes can be 10 times that on unburned slopes. Additionally, revegetation projects may fail because of annual fluctuations in precipitation. Biological soil crusts, particularly mosses, can reduce soil erosion and help retain soil water, improving native plant restoration after fires. USGS scientists are experimenting with moss restoration using two stabilization methods, a jute net and a hydro-mulch tackifier, which are already used by the USDA Forest Service for soil erosion control on some burned hillslopes. They will compare the jute net against the tackifier to determine how well each method prevents soil erosion and restores mosses and native plants. They will also mimic a 25-year-maximum storm event to determine soil erosion and water runoff. The study aims to aid Federal, State, Tribal, and private landowners throughout the Great Basin in their efforts to protect soils while restoring plants.

\section{Contact}

David A. Pyke, USGS Forest and Rangeland Ecosystem Science Center; david_a_pyke@usgs.gov; 541-750-0989

\section{Publication}

Blankenship, W.D., Condon, L.A., and Pyke, D.A., in press, Hydroseeding tackifiers and dryland moss restoration potential: Restoration Ecology, early view of online version of record posted June 17, 2019, https://doi.org/10.1111/rec.12997.

\section{Understanding the Ecological Importance of Biocrusts and Grazing Prescriptions That Minimize Their Disturbance}

Biocrusts develop on the surface of soils, consisting of a community of cyanobacteria, mosses, and lichens, and they are commonly found across natural areas in the arid and semiarid Western United States. Biocrusts help maintain the integrity of soils and plants, reduce erosion, and increase postfire resilience and may have enormous ecosystem benefits, but there are many knowledge gaps. USGS researchers are partnering with the BLM on a study to determine how soil type and hydrology affect the vulnerability of biocrusts to disturbance by grazing. Results from this study may inform grazing prescriptions for various locations and seasons to promote conservation of biocrusts for their ecological benefits.

\section{Contact}

David A. Pyke, USGS Forest and Rangeland Ecosystem Science Center; david_a_pyke@usgs.gov; 541-750-0989

\section{Publications}

Condon, L.A., and Pyke, D.A., 2020, Components and predictors of biological soil crusts vary at the regional vs. plant community scale: Frontiers in Ecology and Evolution, v. 7, January, article 449, https://doi.org/10.3389/fevo.2019.00449.

Condon, L.A., Pietrasiak, N., Rosentreter, R., and Pyke, D.A., in press, Passive restoration of vegetation and biological soil crusts following 80 years of exclusion from grazing across the Great Basin: Restoration Ecology, early view of online version of record posted August 5, 2019, https://doi.org/10.1111/rec.13021.

\section{Increasing Operational Resilience for Sagebrush Ecosystems by Integrating Multiscale Sage-Grouse Metrics}

Conservation planning efforts in the sagebrush ecosystem increasingly use tools that link mapped variation in soil and plant processes to predicted outcomes from disturbance and restoration. Such efforts help make resilience concepts "operational" for managers. However, failure to consider obligate vertebrate species, such as sage-grouse, can hinder these efforts owing to spatiotemporal lags between slower reorganization of plant and soil processes following disturbance and corresponding faster behavioral and demographic responses of fauna to disturbance. USGS scientists are incorporating more refined models of sagegrouse habitat suitability and population performance into resilience-driven decision-support tools through the use of multiscale geospatial overlays, simulation analyses of postdisturbance land cover recovery, and improved sagebrush recovery estimates. These efforts aim to improve prioritization of threats from grass-fire cycles and conifer expansion in the Great Basin, and could be applied more broadly rangewide. 


\section{Contacts}

Peter S. Coates, USGS Western Ecological Research Center; pcoates@usgs.gov; 530-669-5073

Mark A. Ricca, USGS Western Ecological Research Center; mark_ricca@usgs.gov; 530-669-5089

\section{Publication}

Ricca, M.A., and Coates, P.S., 2020, Integrating ecosystem resilience and resistance into decision support tools for multi-scale population management of a sagebrush indicator species: Frontiers in Ecology and Evolution, v. 7, January 14, article 493, https://doi.org/10.3389/fevo.2019.00493.

\section{Bureau of Land Management Seed Warehouse Database}

The BLM National Seed Warehouse program purchases and distributes millions of pounds of seed every year for BLM and partner seeding treatments. Currently, tracking of individual seed bags and pallets is accomplished through paper documents and electronic spreadsheets. Through a collaborative process, the BLM and the USGS are designing an online seed warehouse tracking database to store information about individual seed bags. The database can be used to enhance information collected from seed species, seed testing, seed lot, and vendors to facilitate analyses of seed germination and establishment on treatments throughout the Western United States.

\section{Contact}

David S. Pilliod, USGS Forest and Rangeland Ecosystem Science Center; dpilliod@usgs.gov; 208-426-5202

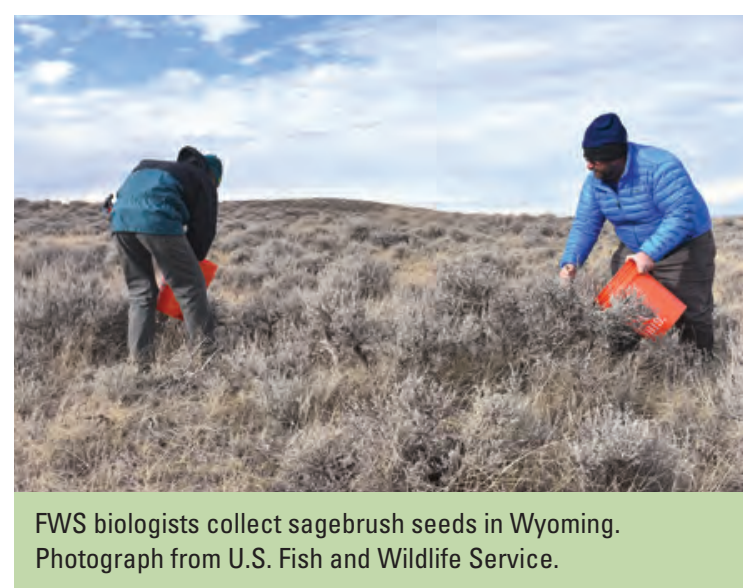

\section{Modeling Recovery of Sagebrush Ecosystems Across the Sage-Grouse Range Using Remotely Sensed Vegetation Products}

Predicting vegetation recovery rates helps inform restoration efforts following disturbance, including fire, and helps inform siting of energy development. However, the ability to predict sagebrush recovery is currently limited by a paucity of research quantifying the spatial and temporal factors that influence recovery across landscapes. Recently, USGS and CSU scientists have developed a framework for modeling changes in sagebrush cover on former well pads using time-varying remote-sensing products (Monroe and others, 2020). This approach will allow scientists to predict rates of and time to recovery of sagebrush cover across broad extents and to evaluate the influence of such factors as weather and soils on outcomes. This approach is currently being extended to sagebrush across the Great Basin and the States of Colorado, Idaho, Montana, Utah, and Wyoming to examine recovery from disturbances (such as those caused by fire and by rehabilitation and restoration practices) reported in the LTDL. This effort will also evaluate recovery predictions under multiple future climate scenarios.

\section{Contacts}

Adrian P. Monroe, USGS Fort Collins Science Center; amonroe@usgs.gov; 970-226-9122

Cameron L. Aldridge, USGS Fort Collins Science Center; aldridgec@usgs.gov; 970-226-9433

David S. Pilliod, USGS Forest and Rangeland Ecosystem Science Center; dpilliod@usgs.gov; 208-426-5202

Collin G. Homer (retired), USGS Earth Resources Observation and Science Center; homer@usgs.gov; 605-594-2714

\section{Publication}

Monroe, A.P., Aldridge, C.L., O’Donnell, M.S., Manier, D.J., Homer, C.G., and Anderson, P.J., 2020, Using remote sensing products to predict recovery of vegetation across space and time following energy development: Ecological Indicators, v. 110, March, article 105872, https://doi.org/10.1016/j.ecolind.2019.105872. 


\section{Standards, Methods, and Monitoring—Improving Reclamation Success on Western Public Lands}

USGS researchers are working to improve the success of reclamation efforts on public lands in the Western United States. Their multiphased approach includes (1) analyzing existing reclamation practices, monitoring protocols, and standards; (2) assessing current scientific information on reclamation methods and their effectiveness; and (3) developing a practical guidebook to inform management or policy decisions. In addition, the USGS researchers are developing a web-based, searchable annotated bibliography of the literature pertaining to reclamation practices and monitoring following oil or gas development. USGS researchers are working closely with the BLM to examine previously compiled information on reclamation guidance, practices, monitoring protocols, and standards in resource management plans and other documents. A workshop for subject matter experts is planned to solicit input and refine the guidebook and potential data requirements. The resulting products can help identify a set of core standards, methods, and monitoring requirements that can be used across the Western United States.

\section{Contacts}

Michael C. Duniway, USGS Southwest Biological Science Center; mduniway@usgs.gov; 928-556-7530

David S. Pilliod, USGS Forest and Rangeland Ecosystem Science Center; dpilliod@usgs.gov; 208-426-5202

\section{Evaluating Reclamation Success Following Oil and Gas Development}

USGS scientists developed a new tool - the disturbance automated reference toolset (DART) - to provide regional assessments of land recovery following oil and gas drilling activities. This new tool was developed to help resource managers make informed decisions for future well pad development. The tool incorporates satellite imagery, digital soil mapping, predictive ecological modeling, and field assessments to evaluate vegetation recovery following well pad abandonment. Scientists used the tool to study 1,800 well pads in Colorado, New Mexico, and Utah, comparing vegetation cover of the abandoned sites to surrounding undisturbed areas with roughly equivalent climate, soil, topography, and management histories (other than oil and gas development). Differing recovery rates across environmental gradients and land stewardship suggest that these attributes can be useful for identifying conditions that may promote or hamper pad recovery.

\section{Contact}

Michael C. Duniway, USGS Southwest Biological Science Center; mduniway@usgs.gov; 928-556-7530

\section{Publications}

Nauman, T.W., Duniway, M.C., Villarreal, M.L., and Poitras, T.B., 2017, Disturbance automated reference toolset (DART) - Assessing patterns in ecological recovery from energy development on the Colorado Plateau: Science of the Total Environment, v. 584-585, April 15, p. 476-488, https://doi.org/10.1016/j.scitotenv.2017.01.034.

Nauman, T.W., and Duniway, M.C., 2016, The automated reference toolset-A soil-geomorphic ecological potential matching algorithm: Soil Science Society of America Journal, v. 80, no. 5, p. 1317-1328, https://doi.org/10.2136/sssaj2016.05.0151.

Waller, E.K., Villarreal, M.L., Poitras, T.B., Nauman, T.W., and Duniway, M.C., 2018, Landsat time series analysis of fractional plant cover changes on abandoned energy development sites: International Journal of Applied Earth Observation and Geoinformation, v. 73, p. 407-419, https://doi.org/10.1016/j.jag.2018.07.008. 


\section{Using Long-Term Remote Sensing and an Automated Reference Toolset to Estimate and Predict Postdevelopment Recovery Potential}

Predicting recovery rates of vegetation following disturbance could help inform future placement of energy development to minimize environmental impacts. In this study, USGS scientists are using a time-varying reference approach to monitor and predict recovery of sagebrush ecosystems following disturbance. Within areas where the DART is currently developed in the Wyoming Landscape Conservation Initiative study area, scientists will identify suitable reference sites near well pads and then characterize trends in vegetation recovery at disturbed sites relative to reference sites at 1- to 2-year intervals from 1985 to 2018. These data can enable modeling to determine how recovery potential changes over time according to differences in soils, weather, and well pad characteristics, and predict time to recovery. This information and resulting spatial data can help inform future development and planning processes.

\section{Contacts}

Adrian P. Monroe, USGS Fort Collins Science Center; amonroe@usgs.gov; 970-226-9122

Michael C. Duniway, USGS Southwest Biological Science Center; mduniway@usgs.gov; 928-556-7530

Cameron L. Aldridge, USGS Fort Collins Science Center; aldridgec@usgs.gov; 970-226-9433

\section{Publication}

Monroe, A.P., Aldridge, C.L., O’Donnell, M.S., Manier, D.J., Homer, C.G., and Anderson, P.J., 2020, Using remote sensing products to predict recovery of vegetation across space and time following energy development: Ecological Indicators, v. 110, March, article 105872, https://doi.org/10.1016/j.ecolind.2019.105872.

\section{Landowner Decision Making and Landscape-Level Restoration}

USGS scientists are collaborating with Boise State University and the Boise State graduate student who was awarded a research fellowship from the National Science Foundation's INTERN program to combine spatial models with land treatment data to quantify the efficacy of big sagebrush restoration efforts in the Great Basin. The project will establish a link between landowner restoration decisions and the spatial environmental variability in sagebrush restoration across multiple spatial scales. This information and resulting spatial data can help inform future development and planning processes.

\section{Contact}

David S. Pilliod, USGS Forest and Rangeland Ecosystem Science Center; dpilliod@usgs.gov; 208-426-5202

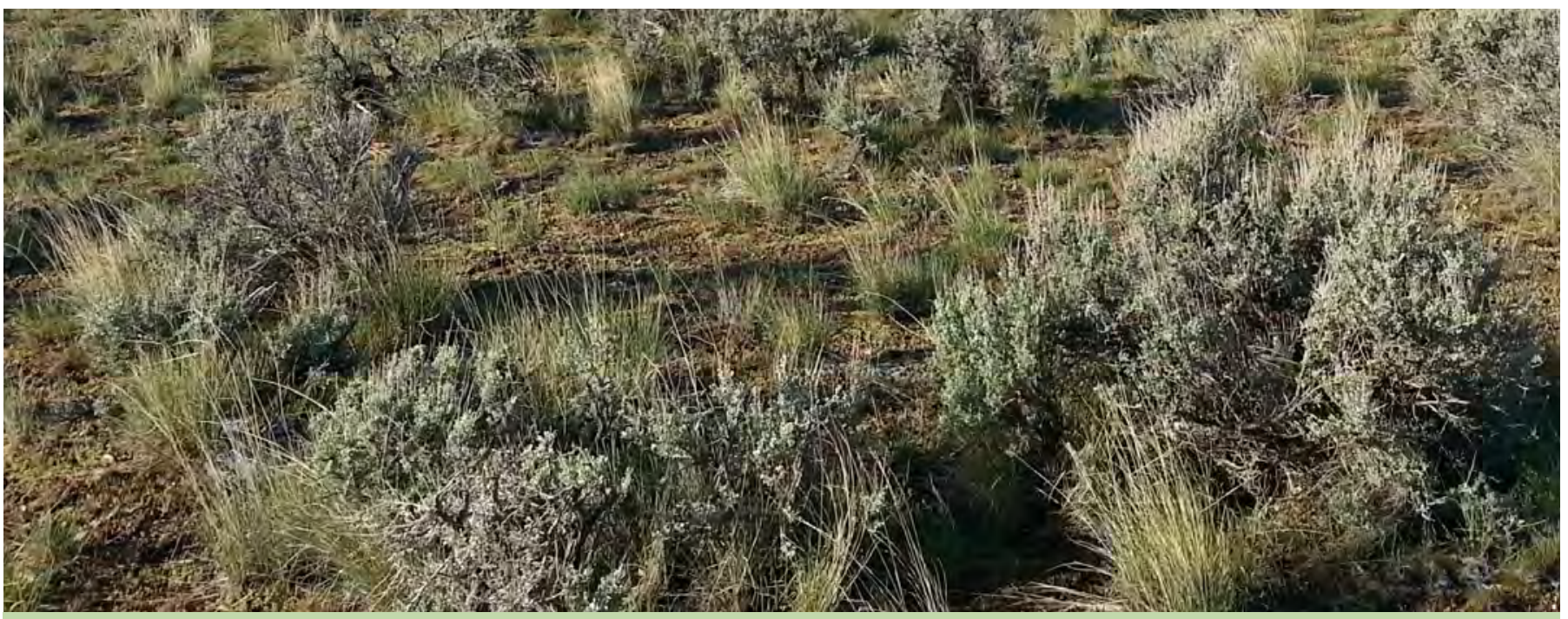

Sagebrush in central Utah. Photograph by Steven Hanser, U.S. Geological Survey. 


\section{Economic Implications of Sagebrush Treatment and Restoration Practices Across the Great Basin and Wyoming}

USGS and CSU researchers will conduct analyses and predictions of sagebrush recovery in the Great Basin and Wyoming and assess the role of weather, soils, and reseeding treatments. They will then leverage these analyses and predictions to conduct a cost-effectiveness analysis. In doing so, they will assess the cost of various practices for treating or restoring sagebrush habitats relative to outcomes while accounting for variation in resilience across space and time. The intent is to pilot a decision support tool that identifies the most efficient investment for the fastest sagebrush recovery in the Great Basin and Wyoming, taking into account site-level conditions, vegetation treatment, and cost.

\section{Contacts}

Adrian P. Monroe, USGS Fort Collins Science Center; amonroe@usgs.gov; 970-226-9122

Cameron L. Aldridge, USGS Fort Collins Science Center; aldridgec@usgs.gov; 970-226-9433

James R. Meldrum, USGS Fort Collins Science Center; jmeldrum@usgs.gov; 970-226-9176

Christopher C. Huber, USGS Fort Collins Science Center; chuber@usgs.gov; 970-226-9219 


\section{Sagebrush, Sage-Grouse, and Other Sagebrush-Associated Species}

Holistically understanding the dynamics within the sagebrush ecosystem can help land managers apply strategies to maintain the ecosystem for the plant and wildlife populations that depend on it. Activities to maintain and improve conditions to benefit sagebrush-associated wildlife, including the greater sage-grouse, can be enhanced through increased information about behavior, habitat use, and population structure of these species. USGS scientists are conducting research to inform management of the sagebrush ecosystem, such as developing sage-grouse monitoring and population analysis tools, mapping sagebrush vegetation cover, and improving the overall ecological understanding of sagebrush-associated species.

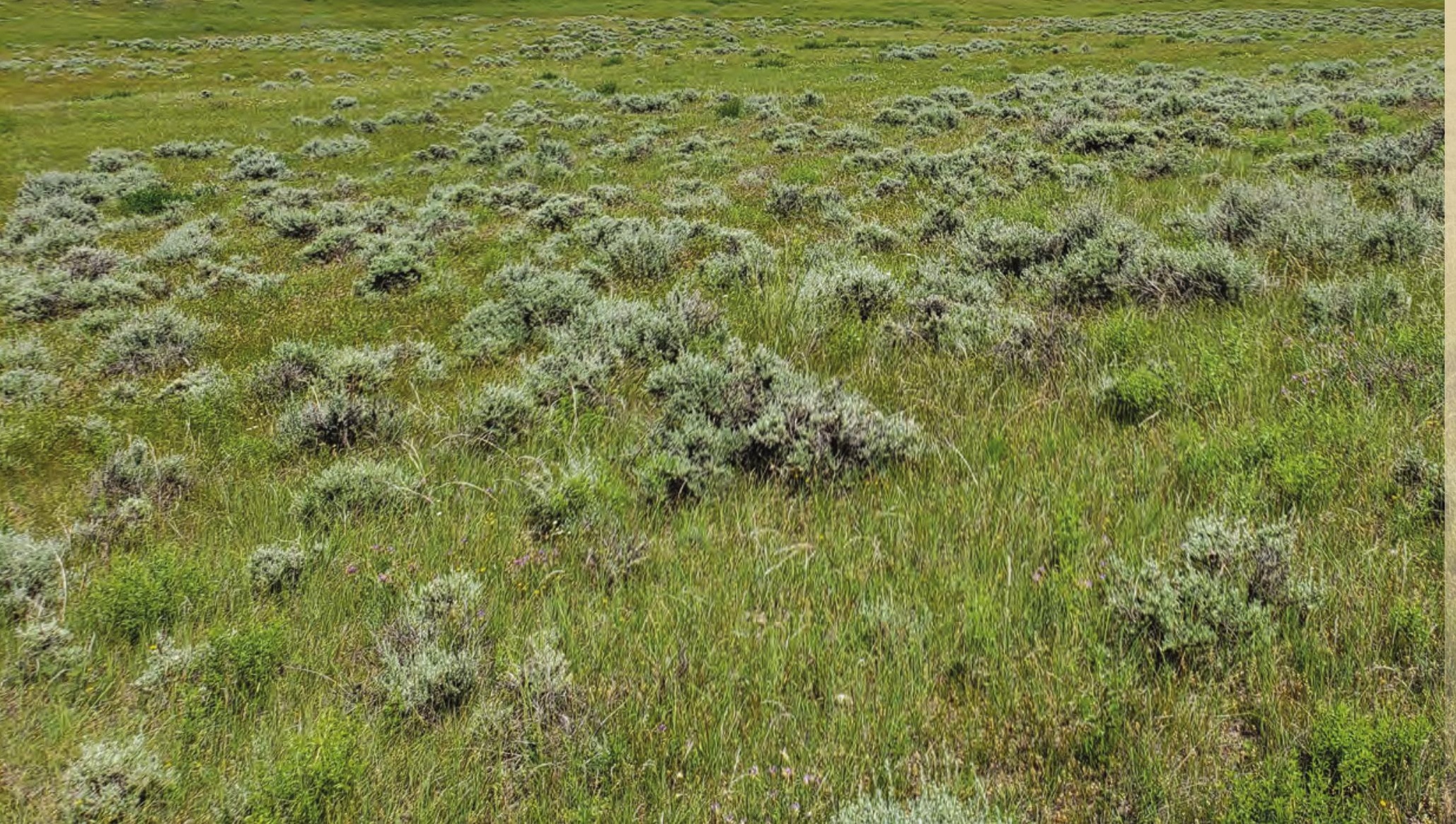




\section{Hierarchical Sage-Grouse Population Assessment Tool—Building a Foundation for True Adaptive Management}

Incorporating spatial and temporal scales into monitoring strategies can provide more robust detection of population rates of change and indicate whether trajectories for those rates of change are driven by local or regional factors. USGS scientists and colleagues have designed a hierarchical monitoring framework for greater sage-grouse in Nevada, Wyoming, and northeastern California that provides a monitoring and detection system to identify sage-grouse breeding locations (known as leks), clusters of leks, and populations. The researchers have worked with the State wildlife agencies and the BLM to expand these approaches to the geographic range of sage-grouse, having compiled the most complete and accurate lek database for sage-grouse across the range. Researchers used these data to develop range-wide hierarchical clusters and are developing the trend modeling approaches to apply across these clusters. The scientists have initial range-wide trend models completed and are working on draft assessments of mechanisms driving population changes, relative to vegetation characteristics, climate, such disturbances as fire and cheatgrass invasion, and other potential management-relevant gradients. The project aims to provide the results within planning tools to assist State and Federal agencies with managing sage-grouse populations and their habitats.

\section{Contacts}

Peter S. Coates, USGS Western Ecological Research Center; pcoates@usgs.gov; 530-669-5073

Cameron L. Aldridge, USGS Fort Collins Science Center; aldridgec@usgs.gov; 970-226-9433

\section{Publications}

Coates, P.S., Prochazka, B.G., Ricca, M.A., Wann, G.T., Aldridge, C.L., Hanser, S.E., Doherty, K.E., O’Donnell, M.S., Edmunds, D.R., and Espinosa, S.P., 2017, Hierarchical population monitoring of greater sage-grouse (Centrocercus urophasianus) in Nevada and California-Identifying populations for management at the appropriate spatial scale: U.S. Geological Survey Open-File Report 2017-1089, 49 p., https://doi.org/10.3133/ofr20171089.

Monroe, A.P., Wann, G.T., Aldridge, C.L., and Coates, P.S., 2019, The importance of simulation assumptions when evaluating detectability in population models: Ecosphere, v. 10, no. 7, article e02791, 16 p., https://doi.org/10.1002/ecs2.2791.

O’Donnell, M.S., Edmunds, D.R., Aldridge, C.L., Heinrichs, J.A., Coates, P.S., Prochazka, B.G., and Hanser, S.E., 2019, Designing multi-scale hierarchical monitoring frameworks for wildlife to support management-A sage-grouse case study: Ecosphere, v. 10, no. 9, article e02872, https://doi.org/10.1002/ecs2.2872.

Wann, G.T., Coates, P.S., Prochazka, B.G., Severson, J.P., Monroe, A.P., and Aldridge, C.L., 2019, Assessing lek attendance of male greater sage-grouse using fine-resolution GPS data-Implications for population monitoring of lek mating grouse: Population Ecology, v. 61, no. 2, p. 183-197, https://doi.org/10.1002/1438-390X.1019.

\section{Western Association of Fish and Wildlife Agencies Sagebrush Conservation Strategy}

USGS scientists are contributing to the development of the Western Association of Fish and Wildlife Agencies Sagebrush Conservation Strategy. This strategy is intended to provide guidance so that the collaborative conservation efforts by State and Federal agencies, academia, Tribes, nongovernmental organizations, and stakeholders to conserve the iconic greater sage-grouse can be expanded to the entire sagebrush biome to benefit the people and wildlife that depend on it. The Sagebrush Conservation Strategy will be presented in two parts. Part A, Challenges to Sagebrush Conservation, is an overview and assessment of the challenges facing land managers and landowners in conserving sagebrush ecosystems. Part B will summarize conservation needs at ecoregional scales, provide an analysis of barriers and impediments to successful conservation of the sagebrush biome at those scales, and present nonregulatory strategies developed through a stakeholder engagement process to overcome these challenges.

\section{Contact}

Steven E. Hanser, USGS Fort Collins Science Center; shanser@usgs.gov; 970-226-9309 


\section{Annotated Bibliography of Scientific Research on Greater Sage-Grouse}

The greater sage-grouse has been a focus of scientific investigation and management action for the past two decades. The sheer number of scientific publications can be a challenge for managers tasked with evaluating and determining the need for potential updates to existing planning documents. To assist in this process, USGS scientists are reviewing and summarizing the scientific literature. Annually, USGS scientists conduct a structured search of reference databases for research or scientific review articles in peer-reviewed journals or formal government technical reports and retain only those products for which sage-grouse or their habitat was a research focus. Each product is summarized and assessed for relevance to a list of 31 management topics that includes sage-grouse biology and habitat characteristics along with potential management actions, land uses, and environmental factors related to sage-grouse management and conservation. The online version of this bibliography is searchable by topic and location and includes links to all original publications (https://apps.usgs.gov/ gsgbib/index.php). An update is in progress that will add publications from 2018 and early 2019.

\section{Contacts}

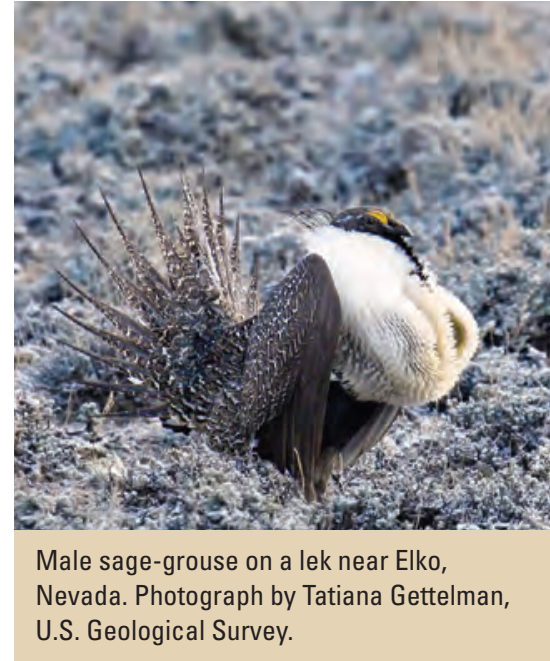

Steven E. Hanser, USGS Fort Collins Science Center; shanser@usgs.gov; 970-226-9309

Sarah K. Carter, USGS Fort Collins Science Center; skcarter@usgs.gov; 970-226-9355

Robert S. Arkle, USGS Forest and Rangeland Ecosystem Science Center, rarkle@usgs.gov; 208-426-5205

\section{Publication}

Carter, S.K., Manier, D.J., Arkle, R.S., Johnston, A.N., Phillips, S.L., Hanser, S.E., and Bowen, Z.H., 2018, Annotated bibliography of scientific research on greater sage-grouse published since January 2015: U.S. Geological Survey Open-File Report 2018-1008, 183 p., https://doi.org/10.3133/ofr20181008. [Interactive, searchable version is available at https://apps.usgs.gov/ gsgbib/index.php.]

\section{Using Advanced Technologies to Improve Population Estimation from Lek Counts}

Population ecologists are challenged with estimating population growth of sensitive species on the basis of animal surveys that are often imperfect in detection. USGS scientists, in collaboration with State and university partners, are conducting multiple studies with advanced technologies to improve population estimates and growth rates from sage-grouse lek count observations. For example, scientists are using high-definition infrared cameras mounted on fixed wing aircraft simultaneously with double-blind ground observations to estimate detection probabilities. Moreover, scientists are employing advanced global positioning system (GPS) transmitters to collect fine-resolution movement data on male sage-grouse to calculate lek visitation rates. These findings can be used to calculate adjustment factors for lek surveys to account for sage-grouse not attending leks and those that were undetected. Adjusted counts could be used by State and Federal partners to improve accuracy of estimated population trends.

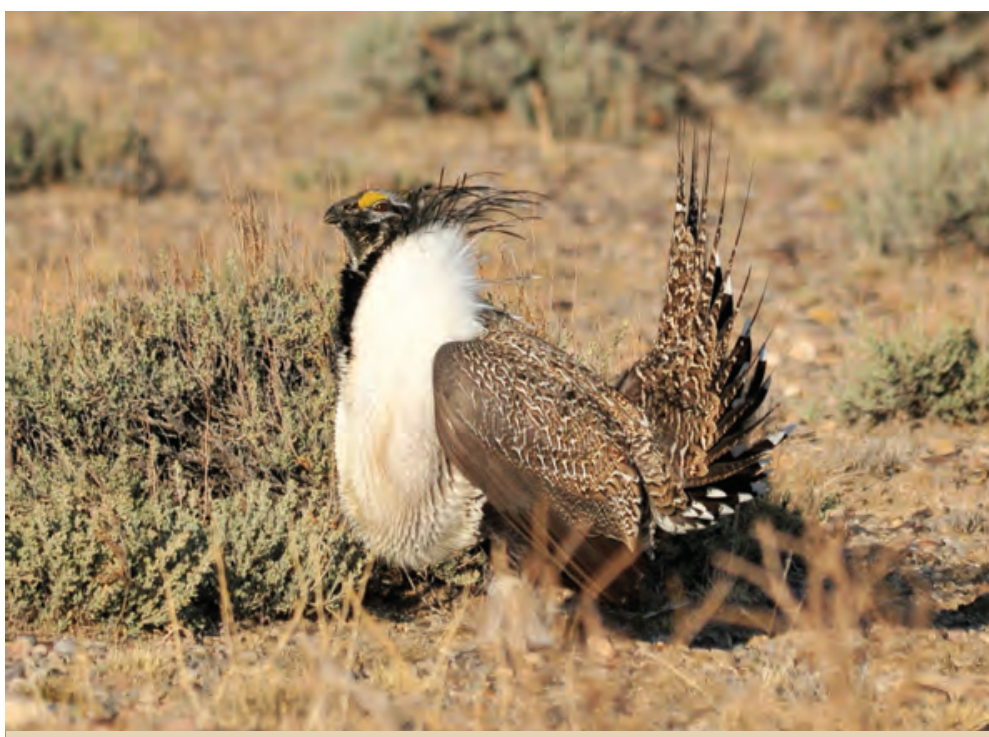

Male sage-grouse on a lek near Elko, Nevada. Photograph by Tom Koerner, U.S. Fish and Wildlife Service. 


\section{Contact}

Peter S. Coates, USGS Western Ecological Research Center; pcoates@usgs.gov; 530-669-5073

\section{Publications}

Coates, P.S., Wann, G.T., Gillette, G.L., Ricca, M.A., Prochazka, B.G., Severson, J.P., Andrle, K.M., Espinosa, S.P., Casazza, M.L., and Delehanty, D.J., 2019, Estimating sightability of greater sage-grouse at leks using an aerial infrared system and N-mixture models: Wildlife Biology, v. 2019, no. 1, https://doi.org/10.2981/wlb.00552.

Gillette, G.L., Coates, P.S., Petersen, S., and Romero, J.P., 2013, Can reliable sage-grouse lek counts be obtained using aerial infrared technology?: Journal of Fish and Wildlife Management, v. 4, no. 2, p. 386-394, https://doi.org/10.3996/032013-JFWM-025.

\section{Marking Effects on Sage-Grouse Survival and Behavior}

Reliable demographic estimates hinge on the assumption that marking animals does not alter behavior, reproduction, or survival. Violations of this assumption can change inferences from the demographic information and are particularly problematic for species of high conservation concern, such as greater sage-grouse, where managers depend on science to guide decisions. The deployment of GPS or similar devices in recent years represents a significant technological advancement that has contributed greatly to the understanding of avian ecology compared with traditionally used very high frequency (VHF) radio transmitters. However, major information gaps remain regarding GPS effects on bird demographic rates, movement behavior, and habitat selection. USGS scientists in collaboration with scientists at the Nevada Department of Wildlife, Idaho State University, and others are leveraging extensive data from sage-grouse across multiple sites and years in the Great Basin that have been marked with GPS and VHF devices using various attachment configuration designs. Results from these studies can help provide guidelines for device use and beneficial design modifications.

\section{Contact}

Peter S. Coates, USGS Western Ecological Research Center; pcoates@usgs.gov; 530-669-5073

\section{Publication}

Severson, J.P., Coates, P.S., Prochazka, B.G., Ricca, M.A., Casazza, M.L., and Delehanty, D.J., 2019, Global positioning system tracking devices can decrease greater sage-grouse survival: The Condor, v. 121, no. 3, article duz032, http://dx.doi.org/10.1093/ condor/duz032.

\section{Importance of Simulation Assumptions When Evaluating Detection Bias in Lek Trend Models}

Greater sage-grouse lek counts are important for investigating a variety of questions, and population models can estimate detectability from repeated counts when modeling population size and trends. Past simulations used to evaluate these models typically assumed detectability is constant or random across sites and years. Thus, it is unknown how these models perform under scenarios when detectability is not constant or random. To address this uncertainty, USGS and CSU scientists used GPS data from sage-grouse to inform simulations of the detection process for counts of this species, including scenarios where detection either varied randomly or declined linearly across years. This information can help inform monitoring protocols to provide State and Federal biologists with more accurate estimates of sage-grouse populations and can lead to improved sage-grouse monitoring and population analysis protocols.

\section{Contacts}

Adrian P. Monroe, USGS Fort Collins Science Center; amonroe@usgs.gov; 970-226-9122

Cameron L. Aldridge, USGS Fort Collins Science Center; aldridgec@usgs.gov; 970-226-9433

Peter S. Coates, USGS Western Ecological Research Center; pcoates@usgs.gov; 530-669-5073

\section{Publication}

Monroe, A.P., Wann, G.T., Aldridge, C.L., and Coates, P.S., 2019, The importance of simulation assumptions when evaluating detectability in population models: Ecosphere, v. 10, no. 7, article e02791, 16 p., https://doi.org/10.1002/ecs2.2791. 


\section{Evaluating Trends in Greater Sage-Grouse Populations With Quantile Regression}

USGS scientists are evaluating the use of a statistical technique known as quantile regression to develop models of sagegrouse population change. Estimates obtained from quantile regression are less sensitive to a few extreme population counts; can be estimated with an easier, more statistically justified approach to dealing with a few counts of zero; and can be extended to include additional covariates. Furthermore, this technique can provide a robust measure of trends and has fewer statistical assumptions. These features are likely to be especially beneficial in estimating population trends for greater sage-grouse.

\section{Contact}

Brian S. Cade, USGS Fort Collins Science Center; cadeb@usgs.gov; 970-226-9326

\section{A Hierarchical Integrated Population Model for Greater Sage-Grouse in the Bi-State Distinct Population Segment in California and Nevada}

Genetic research has indicated isolation and potential conservation risk for the greater sage-grouse in the Bi-State Distinct Population Segment. The USGS developed an integrated population model (IPM) for this area to estimate population growth rates. The model indicates that the Bi-State population is stable overall, but evidence suggests a declining trend for one subpopulation. Scientists recently expanded the IPM to identify relationships between population growth rate and precipitation patterns. These findings provide a framework for hierarchical modeling strategies that separate climate-driven changes in populations from local-scale disturbances. Researchers are now assessing which

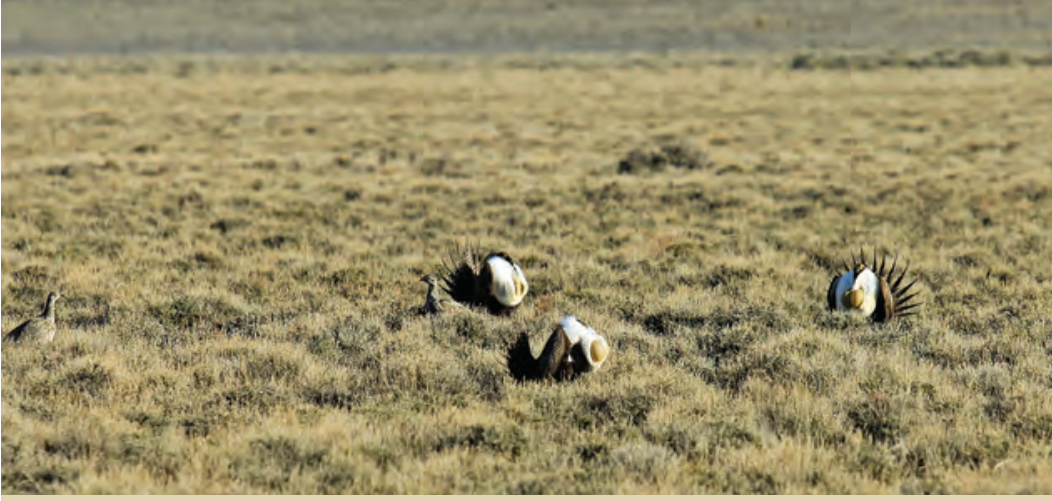

Male sage-grouse on a lek near Elko, Nevada. Photograph by Tatiana Gettelman, U.S. Geological Survey. components of sage-grouse life history are driving population change as well as how and when climate influences particular life-history stages. This research informs active management planning processes in the Bi-State and this approach could be adapted to assess population trends for greater sagegrouse at other regional and landscape scales.

\section{Contact}

Peter S. Coates, USGS Western Ecological Research Center; pcoates@usgs.gov; 530-669-5073

\section{Publications}

Coates, P.S., Halstead, B.J., Blomberg, E.J., Brussee, B., Howe, K.B., Wiechman, L., Tebbenkamp, J., Reese, K.P., Gardner, S.C., and Casazza, M.L., 2014, A hierarchical integrated population model for greater sage-grouse (Centrocercus urophasianus) in the Bi-State Distinct Population Segment, California and Nevada: U.S. Geological Survey Open-File Report 2014-1165, 34 p., https://doi.org/10.3133/ofr20141165.

Coates, P.S., Prochazka, B.G., Ricca, M.A., Halstead, B.J., Casazza, M.L., Blomberg, E.J., Brussee, B.E., Wiechman, L., Tebbenkamp, J., Gardner, S.C., and Reese, K.P., 2018, The relative importance of intrinsic and extrinsic drivers to population growth vary among local populations of greater sage-grouse-An integrated population modeling approach: The Auk, Ornithological Advances, v. 135, no. 2, p. 240-261, https://doi.org/10.1642/AUK-17-137.1.

Coates, P.S., Ricca, M.A., Prochazka, B.G., O’Neil, S.T., Severson, J.P., Mathews, S.R., Espinosa, S., Gardner, S., Lisius, S., and Delehanty, D.J., 2020, Population and habitat analyses for greater sage-grouse (Centrocercus urophasianus) in the Bi-State Distinct Population Segment—2018 update: U.S. Geological Survey Open-File Report 2019-1149, 122 p., http://pubs.er.usgs.gov/publication/ofr20191149. 
Mathews, S.R., Coates, P.S., Prochazka, B.G., Ricca, M.A., Meyerpeter, M.B., Espinosa, S.P., Lisius, S., Gardner, S.C., and Delehanty, D.J., 2018, An integrated population model for greater sage-grouse (Centrocercus urophasianus) in the Bi-State Distinct Population Segment, California and Nevada, 2003-17: U.S. Geological Survey Open-File Report 2018-1177, 89 p., https://doi.org/10.3133/ofr20181177.

\section{Spatially Explicit Conservation Planning Tool for the Bi-State Distinct Population Segment of Greater Sage-Grouse}

Conservation planning efforts must account for a wide array of factors to assist future development, conserve native species, and improve habitat conditions. The USGS has developed a spatially explicit conservation planning tool within the Bi-State Distinct Population Segment that uses modeling results from sage-grouse habitat suitability and space use to assess and prioritize management actions (see citation below). Examples include decision support for prioritizing restoration projects related to wildfire and pinyon and juniper treatments. Results demonstrate how the model output can be an important step in identifying management projects that yield the highest quantifiable benefit to sagegrouse while avoiding costly misallocation of resources. This information helps highlight the importance of considering both changes in sage-grouse responses to habitat conditions and factors influencing sagebrush ecosystem resilience to disturbance and resistance to invasion. This novel framework can be adapted to answer other management questions aimed at improving habitat for species of conservation concern across sagebrush and other ecosystems.

\section{Contact}

Peter S. Coates, USGS Western Ecological Research Center; pcoates@usgs.gov; 530-669-5073

\section{Publications}

Duvall, A.L., Metcalf, A.L., and Coates, P.S., 2017,

Conserving the greater sage-grouse-A social-ecological

systems case study from the California-Nevada Region: Rangeland Ecology \& Management, v. 70, no. 1, p. 129-140, https://doi.org/10.1016/j.rama.2016.08.001.

Ricca, M.A., Coates, P.S., Gustafson, K.B., Brussee, B.E., Chambers, J.C., Espinosa, S.P., Gardner, S.C., Lisius, S., Ziegler, P., Delehanty, D.J., and Casazza, M.L., 2018, A conservation planning tool for greater sage-grouse using indices of species distribution, resilience, and resistance: Ecological Applications, v. 28, no. 4, p. 878-896, https://doi.org/10.1002/eap.1690.

\section{Can Translocation Prevent the Loss of Imperiled Populations of Sage-Grouse in the Bi-State Distinct Population Segment?}

Within the Bi-State Distinct Population Segment (DPS) of greater sage-grouse, populations on the periphery have been declining and the distributional range of the DPS has been decreasing. During the past 30 years, Federal, State, and university collaborators have been collecting lek count and demographic data from radio- and GPS-marked sage-grouse to help inform management decisions aimed at conserving sage-grouse populations. In 2017, a translocation effort was initiated with the goal of infusing new individuals and genetic information into a remnant and isolated subpopulation of sage-grouse on the western 
extreme of the DPS. USGS scientists, in collaboration with multiple universities as well as Federal and State biologists, are investigating the impacts of translocation to the donor and recipient populations using a before-and-after control-impact study design. A variety of other techniques, including implementation of VHF and GPS technology, soft-release methods, artificial insemination, and release of pre-nesting hens as well as hens with broods, are under investigation. Scientists are also evaluating the influence of changes in genetic diversity following translocation on demographic responses, such as nest survival and fecundity. Results of this study will help improve the success of future translocation efforts.

\section{Contact}

Peter S. Coates, USGS Western Ecological Research Center; pcoates@usgs.gov; 530-669-5073

\section{Publication}

Mathews, S.R., Coates, P.S., Prochazka, P.S., Ricca, M.A., Meyerpeter, M.B., Espinosa, S.P., Lisius, S., Gardner, S.C., and Delehanty, D.J., 2018, An integrated population model for greater sage-grouse (Centrocercus urophasianus) in the Bi-State Distinct Population Segment, California and Nevada, 2003-17: U.S. Geological Survey Open-File Report 2018-1177, 89 p., https://doi.org/10.3133/ofr20181177.

\section{Greater Sage-Grouse Response to Habitat Restoration Efforts}

Sagebrush restoration efforts and greater sage-grouse translocations were initiated in 2005 to augment population numbers and prevent extirpation of the Devils Garden population in the FWS Klamath Basin National Wildlife Refuge Complex. Early monitoring efforts were conducted opportunistically without targeted objectives and with limited quantitative data collection. Scientists from the USGS Oregon Cooperative Fish and Wildlife Research Unit, in collaboration with those from Oregon State University and the FWS, are initiating a project to provide a robust evaluation of sage-grouse response to concurrent restoration activities and assess habitat conditions that could be limiting population growth and range expansion. This research will address knowledge gaps regarding dispersal and seasonal movements related to life-cycle needs of greater sage-grouse to inform future restoration actions and sage-grouse translocations.

\section{Contact}

Katie M. Dugger, USGS Oregon Cooperative Fish and Wildlife Research Unit; cdugger@usgs.gov; 541-737-2473

\section{Spatially Explicit State-and-Transition Modeling for Rangeland Conservation Planning- Application to Outcome-Based Grazing and Sage-Grouse Habitat Monitoring}

The natural range of variability of the sagebrush ecosystem in the Great Basin is determined by local climate and topographic and soil relationships associated with plant community development. State-and-transition models (STMs) are widely used as a decision support tool for land managers and can be used to describe the ecological dynamics that occur within areas of similar ecological potential that respond similarly to natural or human-induced disturbances. These areas are referred to as disturbance response groups (DRGs). Scientists from the USGS and University of Nevada-Reno are developing a conservation planning tool for sage-grouse across DRGs and testing the results of outcome-based grazing actions. This work will build on technological advances in remote sensing and land cover products to develop spatially explicit STM maps. Development

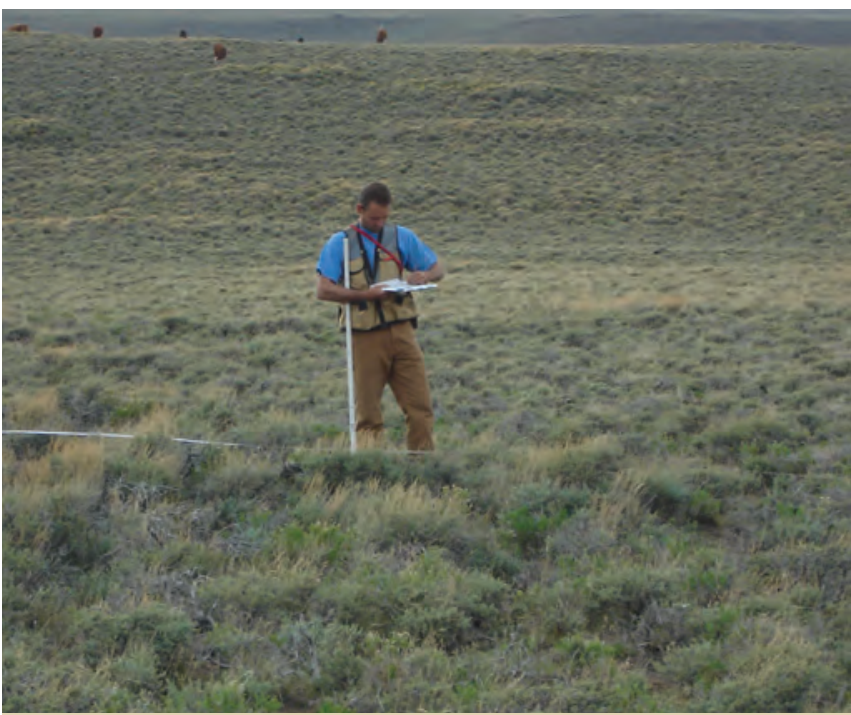

Wildlife biologist monitoring sagebrush habitat. Photograph by Steven Hanser, U.S. Geological Survey. of ecologically relevant maps can provide powerful tools for conservation planning for a variety of management actions, including fuel treatments, grazing permit renewal, sage-grouse habitat management, and postfire rehabilitation. 


\section{Contacts}

Peter S. Coates, USGS Western Ecological Research Center; pcoates@usgs.gov; 530-669-5073

Mark A. Ricca, USGS Western Ecological Research Center; mark_ricca@usgs.gov; 530-669-5089

Collin G. Homer (retired), USGS Earth Resources Observation and Science Center; homer@usgs.gov; 605-594-2714

\section{Impacts of Free Roaming Equids and Livestock on Greater Sage-Grouse and Sagebrush Ecosystems}

Abundant populations of equids (wild horses and burros) in the Great Basin pose challenges for multiple-use management of BLM rangelands, which includes cattle production and conservation of sagebrush-obligate species such as greater sage-grouse. Although previous research points towards sagebrush degradation from overly abundant equids, direct linkages to sage-grouse population dynamics and behavior are sparse in the literature. USGS scientists and collaborators are bridging these information gaps through long-term studies of lek disturbance by large herbivores (equids, cattle, and native ungulates) and newly launched studies of cattle and equid movements and resource utilization encompassing sage-grouse monitoring across Nevada. These efforts can also help inform outcome-based grazing programs by separating equid effects from livestock effects.

\section{Contacts}

Peter S. Coates, USGS Western Ecological Research Center; pcoates@usgs.gov; 530-669-5073

Mark A. Ricca, USGS Western Ecological Research Center; mark_ricca@usgs.gov; 530-669-5089

Kathryn A. Schoenecker, USGS Fort Collins Science Center; schoeneckerk@usgs.gov; 970-226-9329

\section{Reintroduction and Population Establishment of Columbian Sharp-Tailed Grouse Within Sagebrush Ecosystems in Nevada}

Translocation is a management technique that involves moving animals from a source population to a target location or population. This technique is implemented as a conservation practice in reintroduction programs, and it is meant to augment remnant populations as well as reestablish extirpated populations. For communal lekking grouse species in North America (genera Tympanuchus and Centrocercus), population restoration by way of translocation is often challenging because these species exhibit fidelity to areas of reproductive activities (that is, sites for courtship displays, nesting, and brood-rearing activities). A thorough understanding of translocation effects and effective management practices can be accomplished with welldesigned postrelease monitoring programs. Columbian sharp-tailed grouse (T. columbianus phasianellus; CSTG) were extirpated from sagebrush ecosystems in northern Nevada more than 50 years ago. USGS scientists working in collaboration with Nevada Department of Wildlife, Idaho Department of Fish and Game, and Idaho State University reintroduced CSTG to Nevada from Idaho from 2013 to 2017. This translocation project is designed to accomplish a conservation goal of reestablishing native CSTG populations to the historic range within sagebrush ecosystems and to meet a scientific goal of understanding how lekking species that exhibit cultural transmission can be reestablished in previously unoccupied areas. Although the research is ongoing, the newly established population appears to be stable in the near-term. Results from these studies will help inform future conservation and management projects focused on the restoration of native communal lekking grouse in North America.

\section{Contact}

Peter S. Coates, USGS Western Ecological Research Center; pcoates@usgs.gov; 530-669-5073

\section{Publications}

Mathews, S.R., Coates, P.S., and Delehanty, D.J., 2016, Survival of translocated sharp-tailed grouse-Temporal threshold and age effects: Wildlife Research, v. 43, no. 3, p. 220-227, https://doi.org/10.1071/WR15158.

Mathews, S.R., Coates, P.S., Fike, J.A., Schneider, H., Fischer, D., Oyler-McCance, S.J., Lierz, M., and Delehanty, D.J., 2018, Post-release breeding of translocated sharp-tailed grouse and an absence of artificial insemination effects: Wildlife Research, v. 46, no. 1, p. 12-24, https://doi.org/10.1071/WR18094. 


\section{Decision Support Models for Effective Population Restoration Through Translocation of Prairie-Grouse and Sage-Grouse}

Translocation is a conservation strategy aimed at moving animals from one location to another with the goal of reestablishing or augmenting a target population. Dispersal and reduced population vital rates (that is, rates of survival and reproduction) of translocated prairie-grouse and sage-grouse following release in new areas are typical problems that cause restoration efforts to fail. USGS scientists, in collaboration with Utah State University and Idaho State University, are developing decision support tools to help improve the success of these efforts. These tools use model outputs from the postrelease vital rates of translocated grouse across multiple studies in California, Nevada, North Dakota, and Utah. The vital rate and habitat use dataset to support these models was developed using information from multiple grouse translocation projects across multiple regions through extensive collaborations among State and Federal agencies (California Department of Fish and Game, Idaho Department of Fish and Game, Nevada Department of Wildlife, North Dakota Game and Fish Department, Utah Division of Wildlife Resources, Wyoming Game and Fish Department, FWS, BLM). Scientists are using these data collectively to explore postrelease movement and vital rate responses with a series of models that include translocation-specific step-selection functions, integrated population models, and individual based models to produce spatially explicit maps to guide management decisions. Modeled outputs will inform management, provide assessments of candidate translocation sites, and help focus translocation efforts on those populations where postrelease movements could be minimized, and increased population growth would be expected.

\section{Contact}

Peter S. Coates, USGS Western Ecological Research Center; pcoates@usgs.gov; 530-669-5073

\section{Integrating Wildlife Habitat Models With State-And-Transition Models to Enhance the Management of Rangelands for Multiple Objectives}

State-and-transition models (STMs) are a tool used in rangeland management to describe linear and nonlinear vegetation dynamics, but they could be improved by addressing wildlife habitat needs, which would illustrate the tradeoffs in managing for different ecosystem services. USGS researchers and partners developed avifauna density models for songbirds and sage-grouse, incorporating predictions into a collaboratively developed STM for a native grassland state and an exotic-dominated state that is divided into a shrubland and grassland phase in the northwest. Moderate or increasing shrub cover were important predictors for shrub-associated species, and responses to understory components varied. Models predicted higher densities of shrub-associated bird species in the shrub-dominated phases and higher densities for grassland-associated bird species in the state and phase lacking shrub cover. However, no single state or phase captured the highest density for all bird species, illustrating the importance of landscape heterogeneity. These results also illustrate the value of using quantitative wildlife habitat models within the range of vegetation conditions associated with each STM state or phase to understand how bird density can change within states and phases. This research will assist local land managers and landowners in conservation decisions.

\section{Contacts}

Cameron L. Aldridge, USGS Fort Collins Science Center; aldridgec@usgs.gov; 970-226-9433

Jennifer M. Timmer, Colorado State University; timmerj3@gmail.com; 517-775-5906

\section{Publication}

Timmer, J.M., Aldridge, C.L., and Fernández-Giménez, M.E., 2019, Managing for multiple species-Greater sage-grouse and sagebrush songbirds: The Journal of Wildlife Management, v. 83, no. 5, p. 1043-1056, https://doi.org/10.1002/jwmg.21663. 


\section{Greater Sage-Grouse Seasonal Habitat Models}

Sage-grouse have a variety of habitat needs, and understanding these requirements in a spatial context is important information for management strategies. USGS and CSU scientists developed seasonal habitat suitability models for the Great Basin by incorporating region-specific habitat conditions specified in the 2015 BLM resource management plans, the Shrubland Components of the USGS National Land Cover Database, and other resource-condition data. The researchers produced maps for breeding, nesting, brood-rearing, and summer habitat. These maps performed poorly at capturing sagegrouse telemetry locations, suggesting the need to develop regional seasonal habitat models based on sage-grouse telemetry data. USGS scientists are continuing to work with partners to explore opportunities to develop rangewide seasonal habitat models using collaborative and advanced data-driven approaches.

\section{Contacts}

Cameron L. Aldridge, USGS Fort Collins Science Center; aldridgec@usgs.gov; 970-226-9433

Greg T. Wann, USGS Fort Collins Science Center; wanng@usgs.gov; 970-226-9440

Michael O’Donnell, USGS Fort Collins Science Center; odonnellm@usgs.gov; 970-226-9407

Steven E. Hanser, USGS Fort Collins Science Center; shanser@usgs.gov; 970-226-9309

\section{Sage-Grouse Ecology and Seasonal Habitats in South Dakota}

Sage-grouse populations in South Dakota have declined significantly over the past decade for unknown reasons. Population declines in sage-grouse are commonly attributed to habitat loss, and conservation actions for sage-grouse often concentrate on habitat management. New GPS transmitters can record several locations each day to provide detailed information on habitat use that can improve understanding of habitat relationships by enabling assessment of variability among individuals in habitat use within seasons. In collaboration with the BLM, USGS scientists are tracking sage-grouse with GPS transmitters to (1) evaluate and map seasonal habitat suitability, (2) quantify effects of disturbances, and (3) evaluate changes in survival and reproduction over the past decade. Results of this study can inform habitat prioritization and identify factors that influence population dynamics.

\section{Contact}

Aaron N. Johnston, USGS Northern Rocky Mountain Science Center; ajohnston@usgs.gov; 406-994-7158

\section{Seasonal Habitat Maps for Sage-Grouse in Montana and the Dakotas}

Spatially extensive maps of habitat suitability with high spatial resolution are useful tools for wildlife management and research but are unavailable for sage-grouse in Montana and the Dakotas. USGS scientists are synthesizing existing telemetry data for sage-grouse across these States to develop maps of habitat suitability for nesting, summer, and winter seasons, based on new geographic information system (GIS) layers for habitat features in the sagebrush ecosystem. This study will provide information and habitat maps that can advance sage-grouse research and inform decision making at local and landscape levels, including prioritization to conserve and restore sage-grouse habitat in the region.

\section{Contact}

Aaron N. Johnston, USGS Northern Rocky Mountain Science Center; ajohnston@usgs.gov; 406-994-7158 


\section{Mapping of Greater Sage-Grouse Habitat in Nevada and Northeastern California}

The USGS is studying the cumulative impacts of expanding human activities across sagebrush landscapes in Nevada and northeastern California. By combining land cover information with data on sage-grouse movement patterns, life history and reproductive ecology, and habitat preferences, researchers can create maps that forecast the interaction of proposed land use activities and the sagebrush ecosystem. Maps help predict where fragmentation of sage-grouse movement corridors and breeding grounds might occur and help in the assessment of relationships between land use and native and invasive species. Additional work is now underway that will (1) describe spatial variation in habitat selection through meta-analyses, (2) identify life-history-specific macrohabitat requirements, and (3) depict spatially explicit survival consequences of habitat selection decisions by sage-grouse. This research can inform land management and conservation planning efforts for sage-grouse and the habitats on

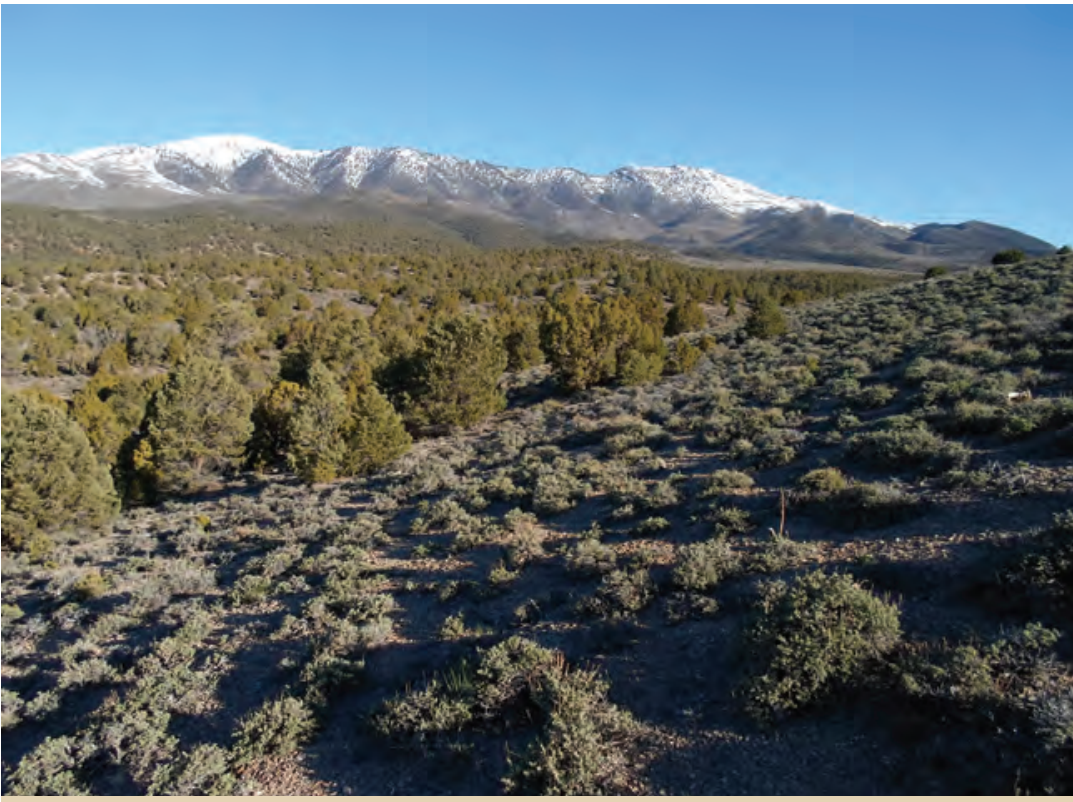

Conifer woodland and sagebrush on Spruce Mountain in Nevada. Photograph by Steven Hanser, U.S. Geological Survey.

which they rely.

\section{Contact}

Peter S. Coates, USGS Western Ecological Research Center; pcoates@usgs.gov; 530-669-5073

\section{Publications}

Coates, P.S., Casazza, M.L., Brussee, B.E., Ricca, M.A., Gustafson, K.B., Sanchez-Chopitea, E., Mauch, K., Niell, L., Gardner, S., Espinosa, S., and Delehanty, D.J., 2016, Spatially explicit modeling of annual and seasonal habitat for greater sage-grouse (Centrocercus urophasianus) in Nevada and Northeastern California-An updated decision-support tool for management: U.S. Geological Survey Open-File Report 2016-1080, 160 p., https://doi.org/10.3133/ofr20161080.

Coates, P.S., Brussee, B.E., Ricca, M.A., Severson, J.P., Casazza, M.L., Gustafson, K.B., Espinosa, S.P., Gardner, S.C., and Delehanty, D.J., 2020, Spatially explicit models of seasonal habitat for greater sage-grouse at broad spatial scalesInforming areas for management in Nevada and northeastern California: Ecology and Evolution, v. 10, no. 1, p. 104-118, https://doi.org/10.1002/ece3.5842.

Coates, P.S., Casazza, M.L., Ricca, M.A., Brussee, B.E., Blomberg, E.J., Gustafson, K.B., Overton, C.T., Davis, D.M., Niell, L.E., Espinosa, S.P., Gardner, S.C., and Delehanty, D.J., 2016, Integrating spatially explicit indices of abundance and habitat quality—An applied example for greater sage-grouse management: Journal of Applied Ecology, v. 53, no. 1, p. 83-95, https://doi.org/10.1111/1365-2664.12558. 


\section{Microhabitat Requirements of Greater Sage-Grouse Within the Great Basin}

Habitat management guidelines with specific management objectives for greater sage-grouse habitat requirements have been published. A disproportionate number of the scientific studies on which these guidelines are based have focused on the northeastern portion of sagegrouse range and might not accurately reflect the Great Basin ecosystem. Building on information in the population ecology book being prepared by USGS scientists and colleagues (see previous project description), the second synthesis will culminate in an easy-to-follow management guideline handbook specifically focused on the Great Basin. This synthesis will include an evaluation of existing macrohabitat and microhabitat objectives across life-history stages and will use a multiyear dataset of VHF and GPS telemetry data and microhabitat measures collected across more than 12 sites in the Great Basin. The synthesis will provide statistics regarding numerous microhabitat factors for selection and survival to meet timely and best-available science needs for land managers and policymakers.

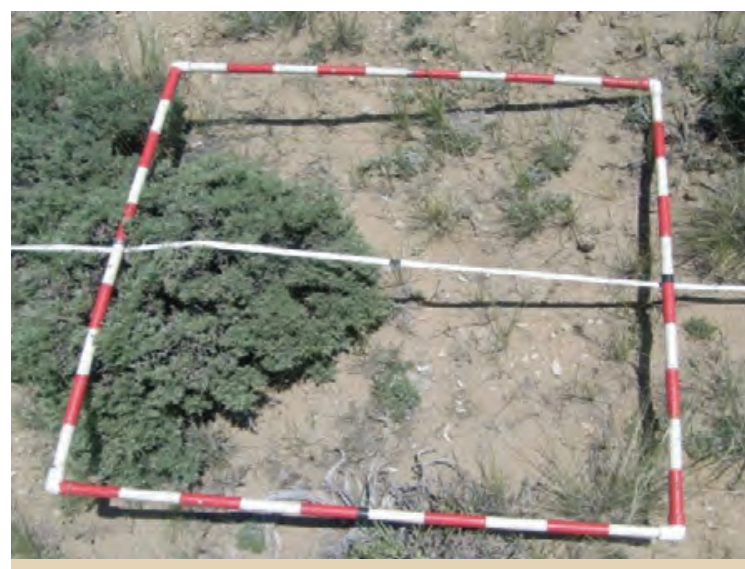

Sagebrush vegetation monitoring. Photograph by Collin Homer, U.S. Geological Survey.

\section{Contact}

Peter S. Coates, USGS Western Ecological Research Center; pcoates@usgs.gov; 530-669-5073

\section{Publication}

Coates, P.S., Brussee, B.E., Ricca, M.A., Dudko, J.E., Prochazka, B.G., Espinosa, S.P., Casazza, M.L., and Delehanty, D.J., 2017, Greater sage-grouse (Centrocercus urophasianus) nesting and brood-rearing microhabitat in Nevada and California-Spatial variation in selection and survival patterns: U.S. Geological Survey Open-File Report 2017-1087, 79 p., https://doi.org/10.3133/ofr20171087.

\section{Informing the Habitat Assessment Framework Process-An Assessment to Understand Habitat Patch Composition and Configuration Requirements for Range-Wide Sage-Grouse Persistence}

For the Bureau to assess the suitability of habitat patches for sage-grouse and help maintain healthy sage-grouse populations, the BLM requires scientifically based, quantifiable estimates of habitat patch composition and configuration requirements for sage-grouse across the species' range. These estimates are required by the BLM when implementing the Sage-grouse Habitat Assessment Framework (HAF) 2.0. To address these information needs, USGS scientists are developing multiple products to directly inform the HAF process, including persistence models to identify important patch characteristics affecting lek persistence, thresholds of patch characteristics at which persistence is likely (including potential regional variation), and maps and datasets of patch metrics that could be used for HAF assessments, at appropriate scales.

\section{Contact}

Cameron L. Aldridge, USGS Fort Collins Science Center; aldridgec@usgs.gov; 970-226-9433 


\section{SageDAT—Data and Tools to Support Collaborative Sagebrush Ecosystem Conservation and Management}

The USGS, the BLM, the FWS, and the Western Association of Fish and Wildlife Agencies have recently initiated development of a new DOI-funded effort, known as SageDAT. SageDAT, which can be accessed at https://sagedat.org, provides a mechanism for sharing and leveraging of data resources, increasing communication and coordination between organizations, and allowing for broader participation and transparency in decision making. The SageDAT team is using emerging technologies to allow effective sharing and discoverability of relevant data and tools that can be used to address the complex challenges that exist in sagebrush ecosystems, including wildfire, invasive annual grass species, land use management, and assessments focusing on the greater sage-grouse.

\section{Contacts}

Steven E. Hanser, USGS Fort Collins Science Center; shanser@usgs.gov; 970-226-9309

John (Dell) L. Long, USGS Fort Collins Science Center; jllong@usgs.gov; 970-226-9184

\section{Remote Sensing Characterization and Monitoring of Shrubland Components in the Western United States}

The USGS, in collaboration with the BLM, completed a remote-sensing-based characterization of shrublands across the Western United States, including all the sagebrush biome, as part of the National Land Cover Database 2016. This work provides a suite of datasets that not only characterize the landscape in ways to maximize application utility but also provide a foundation for both historical and future monitoring at ecosystem scales. In each 30-meter pixel, these products quantify the proportion of shrub, sagebrush, herbaceous, annual herbaceous, litter, and bare ground at 1-percent intervals and the height of shrubs and sagebrush in 1-centimeter intervals. Research has shown this information enables generation of a variety of wildlife habitat predictions, including sage-grouse habitat. Because products will be integrated into the National Land Cover Database, they are now planned for future updating on a regular 2-year cycle, starting with a product representing ground conditions in 2019 and 2020. Updated products will exclude additional nonrangeland areas, particularly in pinyon-juniper stands. Current products are available at https://www.mrlc.gov/data.

\section{Contacts}

Collin G. Homer (retired), USGS Earth Resources Observation and Science Center; homer@usgs.gov; 605-594-2714

Matthew Rigge, USGS Earth Resources Observation and Science Center; mrigge@contractor.usgs.gov; 605-594-2894

Bruce K. Wylie, USGS Earth Resources Observation and Science Center; wylie@usgs.gov; 605-594-6078

\section{Publications}

Rigge, M., Homer, C., Cleeves, L., Meyer, D.K., Bunde, B., Shi, H., Xian, G., Schell, S. and Bobo, M., 2020, Quantifying Western U.S. rangelands as fractional components with multi-resolution remote sensing and in situ data: Remote Sensing, v. 12, no. 3, article 412, https://doi.org/10.3390/rs12030412.

Xian, G., Homer, C., Meyer, D., and Granneman, B., 2013, An approach for characterizing the distribution of shrubland ecosystem components as continuous fields as part of NLCD: ISPRS Journal of Photogrammetry and Remote Sensing, v. 86, p. 136-149, https://doi.org/10.1016/j.isprsjprs.2013.09.009.

Xian, G., Homer, C., Rigge, M., Shi, H., and Meyer, D., 2015, Characterization of shrubland ecosystem components as continuous fields in the northwest United States: Remote Sensing of Environment, v. 168, p. 286-300, https://doi.org/10.1016/j.rse.2015.07.014. 


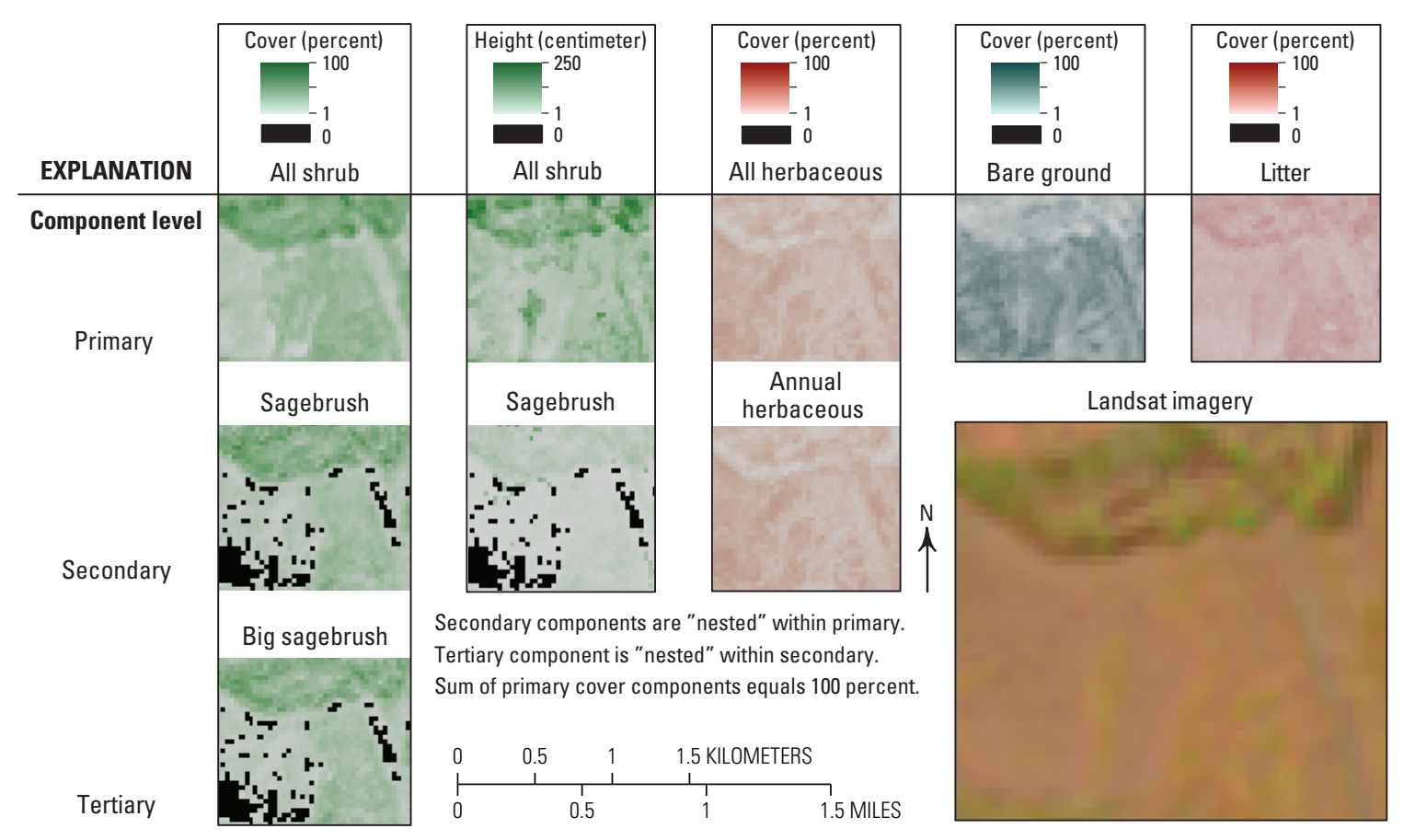

Mapped shrubland components, sorted by their hierarchical level. Component groups are contained by black boxes. For example, within the all shrub primary component group, sagebrush is secondary, and big sagebrush is tertiary. So big sagebrush cover and extent is never greater than sagebrush. Similarly, sagebrush cover and extent is never greater than all shrub cover. The sum of primary cover components (all shrub, all herbaceous, bare ground, and litter) is 100 percent in a typical rangeland environment. Pixels with zero percent cover or height for each component are depicted in black pixels (from Young, 2017).

\section{Developing Temporal Trends in Sagebrush Vegetation Characteristics Over a Large Landscape}

The completion of the USGS shrubland component maps (see previous project description) provides an opportunity to map vegetation component change from 1985 through 2018 using the Landsat archive. Products that describe change over time support research in sage-grouse habitat and population dynamics, restoration success, forecasting future climate change and trends, treatment recovery analysis, and cheatgrass change dynamics. This new approach automates component change analysis by Landsat path and row and has been developed as an extensive scripted process to support processing the large amounts of data required. This approach allows unprecedented comprehensive analysis of shrub and grass change across time. A dataset that includes the percent cover of bare ground, herbaceous, annual herbaceous, litter, shrub, and sagebrush has been completed across the Western United States at annual time-steps from 1985 through 2018. Results show that shrub, sagebrush, herbaceous, and litter cover decreased, and bare ground and annual herbaceous cover increased, over the 1985-2018 study period across the West. The process will be further updated to run on larger composited blocks of imagery, and plans are in place to produced data for 2019 and 2020 in 2021. The USGS plans to continue working with the BLM to ensure continuous monitoring of component change into the future.

\section{Contacts}

Collin G. Homer (retired), USGS Earth Resources Observation and Science Center; homer@usgs.gov; 605-594-2714

Matthew Rigge, USGS Earth Resources Observation and Science Center; mrigge@contractor.usgs.gov; 605-594-2894

Bruce K. Wylie, USGS Earth Resources Observation and Science Center; wylie@usgs.gov; 605-594-6078 


\section{Publications}

Homer, C.G., Xian, G., Aldridge, C.L., Meyer, D.K., Loveland, T.R., and O’Donnell, M.S., 2015, Forecasting sagebrush ecosystem components and greater sage-grouse habitat for 2050 - Learning from past climate patterns and Landsat imagery to predict the future: Ecological Indicators, v. 55, August, p. 131-145, https://doi.org/10.1016/j.ecolind.2015.03.002.

Rigge, M., Homer, C., Shi, H., and Meyer, D.K., 2019, Validating a Landsat time-series of fractional component cover across western U.S. rangelands: Remote Sensing, v. 11, no. 24, article 3009, https://doi.org/10.3390/rs11243009.

Rigge, M., Homer, C., Shi, H., and Wylie, B., in press, Departures of rangeland fractional component cover from Landsat-based ecological potential in Wyoming, USA: Rangeland Ecology \& Management, corrected proof available online May 27, 2020, https://doi.org/10.1016/j.rama.2020.03.009.

Rigge, M., Homer, C., Wylie, B., Gu, Y., Shi, H., Xian, G., Meyer, D.K., and Bunde, B., 2019, Using remote sensing to quantify ecosystem site potential community structure and deviation in the Great Basin, United States: Ecological Indicators, v. 96, pt. 1, p. 516-531, https://doi.org/10.1016/j.ecolind.2018.09.037.

Rigge, M., Shi, H., Homer, C., Danielson, P., and Granneman, B., 2019, Long-term trajectories of fractional component change in the Northern Great Basin, USA: Ecosphere, v. 10, no. 6, article e02762, https://doi.org/10.1002/ecs2.2762.

Shi, H., Rigge, M., Homer, C.G., Xian, G., Meyer, D.K., and Bunde, B., 2017, Historical cover trends in a sagebrush steppe ecosystem from 1985 to 2013 - Links with climate, disturbance, and management: Ecosystems, v. 21, no. 5, p. 913-929, https://doi.org/10.1007/s10021-017-0191-3.

\section{Understanding Drivers of Change in Rangeland Vegetation}

Rangeland vegetation is influenced by annual and seasonal variation in weather as well as grazing, invasive species, fire, and other factors. Understanding whether and why vegetation communities are resistant to change and resilient following disturbance is an important area of ecology and crucial for conservation and restoration strategies. This project takes advantage of multiple, existing data sources to improve understanding of the drivers of change in rangeland vegetation communities across the Western United States, including data from historic field surveys in the late 1970s (BLM's Soil-Vegetation Inventory Method) to ongoing field (BLM's Assessment Inventory and Monitoring Program) and remote sensing (USGS's grass-shrub products) datasets. Outcomes of this study can help improve monitoring strategies and management actions in the sagebrush ecosystem.

\section{Contacts}

David S. Pilliod, USGS Forest and Rangeland Ecosystem Science Center; dpilliod@usgs.gov; 208-426-5202

Collin G. Homer (retired), USGS Earth Resources Observation and Science Center; homer@usgs.gov; 605-594-2714

\section{Publications}

Barker, B.S., Pilliod, D.S., Rigge, M., and Homer, C.G., 2019, Pre-fire vegetation drives post-fire outcomes in sagebrush ecosystems_Evidence from field and remote sensing data: Ecosphere, v. 10, no. 11, article e02929, https://doi.org/10.1002/ ecs2.2929.

Barker, B.S., Pilliod, D.S., Welty, J.L., Arkle, R.S., Karl, M.G., and Toevs, G.R., 2018, An introduction and practical guide to use of the Soil-Vegetation Inventory Method (SVIM) data: Rangeland Ecology \& Management, v. 71, no. 6, p. 671-680, https://doi.org/10.1016/j.rama.2018.06.003. 


\section{Rangeland Ecological Potential Based on Long-Term Satellite Archives}

Identifying changes in contemporary vegetation cover conditions and composition relative to long-term ecological potential allows for the disentanglement of spatial patterns related to natural biophysical gradients from patterns related to change associated with land uses and other disturbance types. USGS scientists have developed maps of ecological potential showing the fractional percent cover of shrub, sagebrush, perennial herbaceous plants, litter, and bare ground in Wyoming and the Great Basin. Ecological potential maps correspond to the potential natural vegetation cover expected by biophysical conditions (soils, topography, and climate) in the absence of anthropogenic and natural disturbance, as represented by the greenest and least disturbed period of the Landsat archive. Models were trained using fractional component cover maps on ecologically intact sites. The researchers generated estimates of vegetation cover departure by comparing the ecological potential to the contemporary fractional cover. The departures represent land cover change from potential land cover and (or) within-state changes in or about 2015. The influence of land management practices and other known disturbances, such as energy development, fires, and vegetation treatments, on vegetation cover is visible on the resulting departure maps. Ongoing work will expand this method of ecological potential mapping across the Western United States.

\section{Contacts}

Collin G. Homer (retired), USGS Earth Resources Observation and Science Center; homer@usgs.gov; 605-594-2714

Matthew Rigge, USGS Earth Resources Observation and Science Center; mrigge@contractor.usgs.gov; 605-594-2894

Bruce K. Wylie, USGS Earth Resources Observation and Science Center; wylie@usgs.gov; 605-594-6078

\section{Publications}

Rigge, M., Homer, C., Shi, H., and Wylie, B., in press, Departures of rangeland fractional component cover from Landsat-based ecological potential in Wyoming, USA: Rangeland Ecology \& Management, corrected proof available online May 27, 2020, https://doi.org/10.1016/j.rama.2020.03.009.

Rigge, M., Homer, C., Wylie, B., Gu, Y., Shi, H., Xian, G., Meyer, D.K., and Bunde, B., 2019, Using remote sensing to quantify ecosystem site potential community structure and deviation in the Great Basin, United States: Ecological Indicators, v. 96, pt. 1, p. 516-531, https://doi.org/10.1016/j.ecolind.2018.09.037.

\section{Mapping Conifer Encroachment Within California and Nevada}

Conifer encroachment is a threat to the extent of sagebrush shrublands in the Great Basin. High-resolution maps of conifers within sagebrush ecosystems are lacking. These maps would be highly useful to land and wildlife management agencies for habitat improvement plans. Therefore, the USGS is currently mapping conifer encroachment at 1-meter resolution across Nevada and northeastern California. This analysis uses specialized image recognition software to develop usable GIS files of conifer coverage. In areas thought to be pinyon and juniper, the USGS is using criteria to delineate the conifer map into cover classifications at 30-meter resolution to approximate phases of conifer encroachment. These maps can help inform management and conservation strategies, including tree removal to enhance sagebrush ecosystems and sage-grouse populations.

\section{Contact}

Peter S. Coates, USGS Western Ecological Research Center; pcoates@usgs.gov; 530-669-5073

\section{Publications}

Coates, P.S., Gustafson, K.B., Roth, C.L., Chenaille, M.P., Ricca, M.A., Mauch, K., Sanchez-Chopitea, E., Kroger, T.J., Perry, W.M., and Casazza, M.L., 2017a, Geospatial data for object-based high-resolution classification of conifers within greater sage-grouse habitat across Nevada and a portion of northeastern California (ver. 2.0, July 2018): U.S. Geological Survey data release, https://doi.org/10.5066/F7348HVC.

Coates, P.S., Gustafson, K.B., Roth, C.L., Chenaille, M.P., Ricca, M.A., Mauch, K., Sanchez-Chopitea, E., Kroger, T.J., Perry, W.M., and Casazza, M.L., 2017b, Using object-based image analysis to conduct high-resolution conifer extraction at regional spatial scales: U.S. Geological Survey Open-File Report 2017-1093, 40 p., https://doi.org/10.3133/ofr20171093.

Gustafson, K.B., Coates, P.S., Roth, C.L., Chenaille, M.P., Ricca, M.A., Sanchez-Chopitea, E., and Casazza, M.L., 2018, Using object-based image analysis to conduct high-resolution conifer extraction at regional spatial scales: International Journal of Applied Earth Observation and Geoinformation, v. 73, p. 148-155, https://doi.org/10.1016/j.jag.2018.06.002. 


\section{Unmanned Aerial Systems for Improving Satellite-Derived Maps of Vegetation}

Vegetation can be characterized at high spatial resolutions with stereo imagery from unmanned aerial systems (UAS) to improve and validate vegetation maps derived from Landsat imagery and field measures at BLM assessment, inventory, and monitoring (AIM) plots. The goal of this study is to examine the use of UAS to complement AIM data and to inform the development of vegetation maps (fig. 3). In 2019, USGS scientists conducted UAS flights concurrently with BLM AIM surveys at 48 sites within the sagebrush ecosystem across Montana and the Dakotas. Current work is focused on developing vegetation classification and sagebrush height models. These data will facilitate comparisons of habitat heterogeneity at multiple spatial scales. Vegetation metrics from the UAS flights will be aggregated by Landsat pixels to evaluate vegetation maps derived from satellite imagery.

\section{Contacts}

Todd M. Preston, USGS Northern Rocky Mountain Science Center; tmpreston@usgs.gov; 406-994-5034

Aaron N. Johnston, USGS Northern Rocky Mountain Science Center; ajohnston@usgs.gov; 406-994-7158

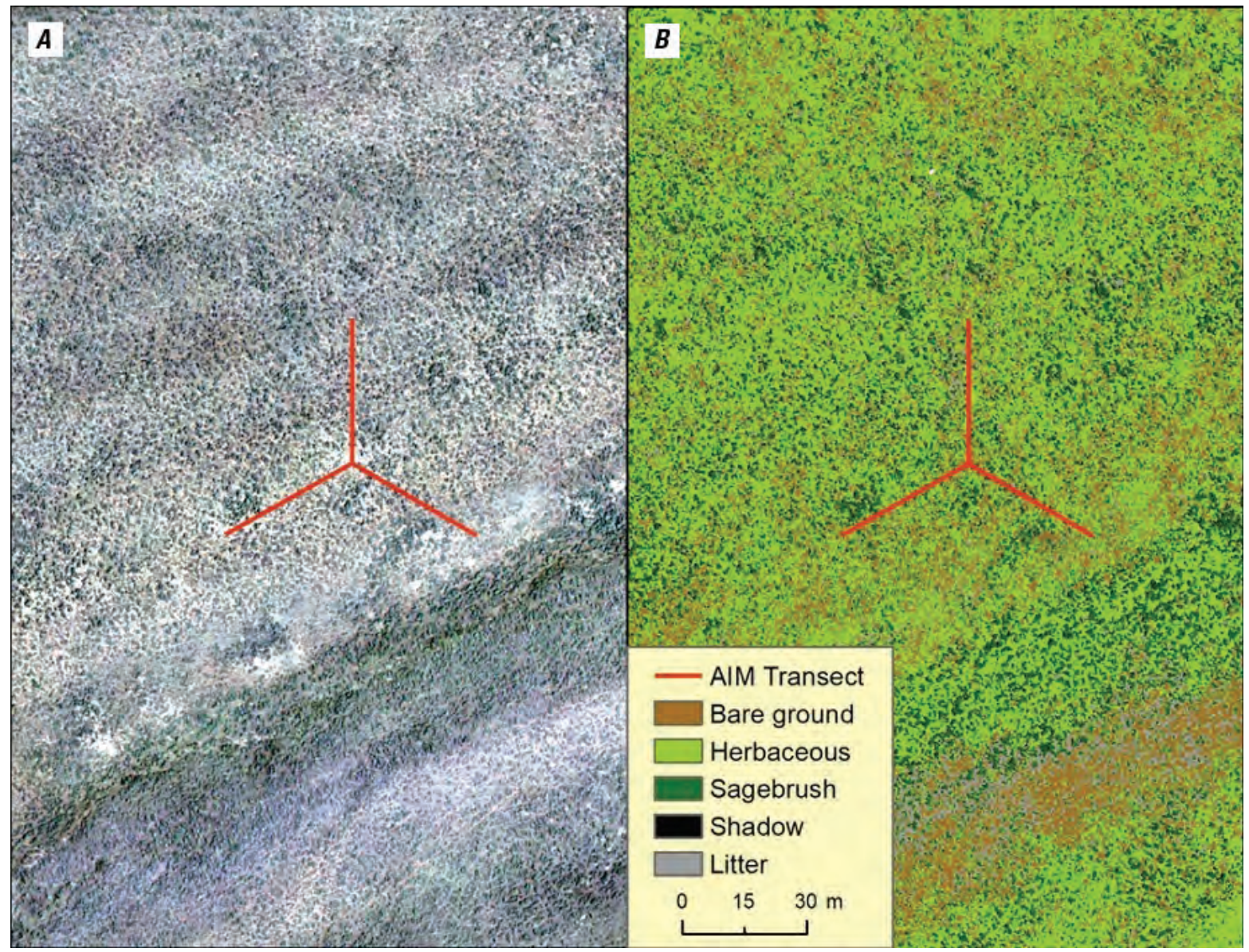

Figure 3. An example of image processing used to reveal information about vegetation type and structure.

$A$, a high-resolution image that was acquired from an unmanned aerial system at an assessment, inventory, and monitoring (AIM) plot in the sagebrush ecosystem in Montana, and $B$, a processed version of that image that provides information about vegetation type and structure. Image and model output provided by Todd Preston, U.S. Geological Survey. 


\section{Sagebrush Ecosystem Performance Mapping in the Great Basin}

Vegetation productivity can be highly variable in arid and semiarid systems. Moisture-related variations in plant productivity add variability to time series data that is not related to management or disturbance. To isolate management and disturbance effects in these systems, "performance" models are being developed that predict sagebrush annual productivity. The deviations of the performance model account for both interannual variation in weather and spatial variation in site potential. Performance anomalies show where the vegetation is not responding to site and weather conditions as would be expected in a healthy sagebrush community. This information can identify areas that are overperforming or underperforming relative to the surrounding landscape and provide managers with a tool to refine or target actions to improve vegetation conditions.

\section{Contact}

Bruce K. Wylie, USGS Earth Resources Observation and Science Center; wylie@usgs.gov; 605-594-6078

\section{Landscape Influence on Gene Flow in Greater Sage-Grouse}

The USGS and collaborators at the USDA Forest Service and University of Waterloo are using genetic information contained in sage-grouse feathers collected at leks to delineate the rangewide network of breeding populations. The genetic data have been analyzed in combination with landscape information to identify geographic distance, topographic features, anthropogenic land uses, and other factors that influence sage-grouse dispersal and genetic exchange. The last part of this work is defining genetic populations across the species range. The results from this study, perhaps the largest terrestrial effort of its kind, will be important for informing conservation planning efforts to delineate core or priority populations and reduce population fragmentation, isolation, and risk of extirpation.

\section{Contact}

Sara J. Oyler-McCance, USGS Fort Collins Science Center; sara_oyler-mccance@usgs.gov; 970-226-9197

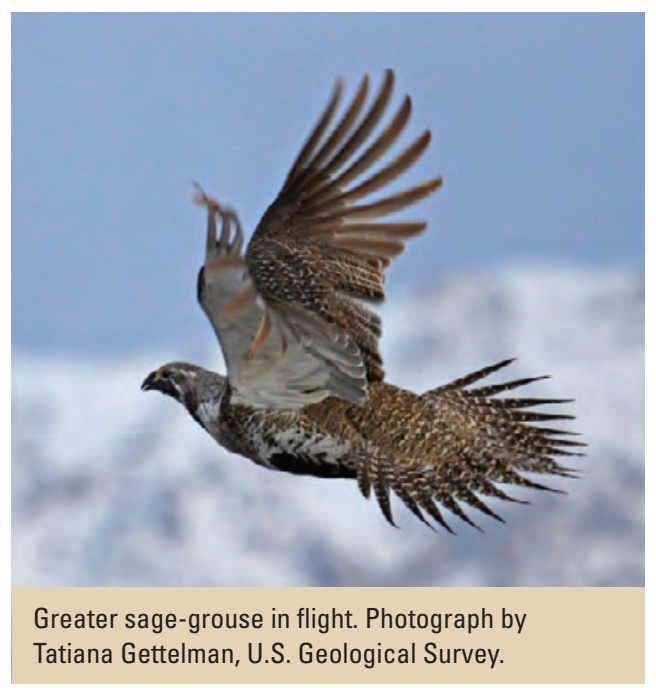

\section{Publications}

Cross, T.B., Schwartz, M.K., Naugle, D.E., Fedy, B.C., Row, J.R., and Oyler-McCance, S.J., 2018, The genetic network of greater sage-grouse-Range-wide identification of keystone hubs of connectivity: Ecology and Evolution, v. 8, no. 11, p. 5394-5412, https://doi.org/10.1002/ece3.4056.

Row, J.R., Doherty, K.E., Cross, T.B., Schwartz, M.K., Oyler-McCance, S.J., Naugle, D.E., Knick, S.T., and Fedy, B.C., 2018, Quantifying functional connectivity-The role of breeding habitat, abundance, and landscape features on range-wide gene flow in sage-grouse: Evolutionary Applications, v. 11, no. 8, p. 1305-1321, https://doi.org/10.1111/eva.12627.

\section{Sage-Grouse Genomics}

USGS scientists and their collaborators have assembled a reference genome for both greater and Gunnison sage-grouse and have performed whole-genome sequencing on six populations of greater sage-grouse (including several on the periphery of the species' range) and Gunnison sage-grouse. This study has helped identify intraspecific population structure and genetic differentiation across the range of these species. The researchers determined that regions that exhibited extreme population differentiation were also associated with candidate genes linked to the metabolism of xenobiotic compounds. Lab work on enzymes isolated from sage-grouse livers provided support for a role for these genes in detoxification of sagebrush, suggesting that the observed interpopulation variation may underlie important local dietary adaptations, warranting close consideration for conservation strategies that link sage-grouse to plant chemistry. 


\section{Contact}

Sara J. Oyler-McCance, USGS Fort Collins Science Center; sara_oyler-mccance@usgs.gov; 970-226-9197

\section{Publications}

Minias, P., Dunn, P.O., Whittingham, L.A., Johnson, J.A., and Oyler-McCance, S.J., 2019, Evaluation of a Chicken 600K SNP genotyping array in non-model species of grouse: Scientific Reports, v. 9, no. 1, article 6407, 10 p., https://doi.org/10.1038/ s41598-019-42885-5.

Oh, K.P., Aldridge, C.L., Forbey, J.S., Dadabay, C.Y., and Oyler-McCance, S.J., 2019, Conservation genomics in the sagebrush sea-Population divergence, demographic history, and local adaptation in sage-grouse (Centrocercus spp.): Genome Biology and Evolution, v. 11, no. 7, p. 2023-2034, https://doi.org/10.1093/gbe/evz112.

Oyler-McCance, S.J., Oh, K.P., Zimmerman, S.J., and Aldridge, C.L., 2020, The transformative impact of genomics on sagegrouse conservation and management, in Rajora, O.P., ed., Population genomics: Cham, Switzerland, Springer International Publishing AG, https://doi.org/10.1007/13836_2019_65.

\section{Incorporating Genetic Information Into Population Monitoring and Assessment Tools}

To better inform and prioritize management decisions for greater sage-grouse, there is an urgent need to understand population trends across the range of the species. USGS scientists are leading a range-wide population trend assessment for sagegrouse, which is a top priority for the FWS and needed to inform recovery efforts. The USGS has been pioneering population trend analyses for sage-grouse across their range. In doing so, the USGS has developed novel approaches to delineate populations and subpopulations across the state, or population clusters (See project "Hierarchical Sage-Grouse Population Assessment Tool—Building a Foundation for True Adaptive Management"). The subpopulation delineation approaches use a clustering algorithm based on lek locations, applied to high resolution sagebrush habitat maps, precipitation and terrain information, and movement and resistance surfaces. Arguably, genetic data could also be included in such monitoring programs, providing a more complete picture of overall species status. The USGS has also been involved with collecting a fine-scale genetic dataset throughout the sage-grouse range, providing a baseline for monitoring future changes in connectivity and genetic diversity resulting from landscape changes. Integrating and assessing genetic data across the population clusters would allow researchers to examine how genetic metrics, such as diversity, could be used as an additional early warning sign to identify leks (or groups of leks) potentially at risk. The USGS and partners are assessing genetic structure across population clusters in Wyoming and Nevada. The USGS is examining how genetic metrics vary in concordance with population demographic metrics and how they could best be incorporated into a monitoring program, which could be applied range-wide.

\section{Contacts}

Cameron L. Aldridge, USGS Fort Collins Science Center; aldridgec@usgs.gov; 970-226-9433

Sara J. Oyler-McCance, USGS Fort Collins Science Center, sara_oyler-mccance@usgs.gov; 970-226-9197

\section{Genomic Scans for Local Adaptation in Greater Sage-Grouse}

Understanding the degree to which different populations might be uniquely adapted to local environmental conditions is critical for developing management plans that will ensure preservation of important functional genetic variation. This is particularly relevant for species like greater sage-grouse that occupy a broad geographic range that spans diverse environmental variables and conditions. New methods of modern DNA sequencing scan the entire genomes of individuals from multiple populations and identify genes that bear the signature of adaptive evolution. Recently, USGS scientists have identified several genes important for diet and immune response in both greater and Gunnison sage-grouse, yet a more comprehensive analysis that examines adaptation to other environmental variables known to be important for greater sage-grouse across the range of the species is warranted. Using the recently completed sage-grouse genome as a reference, USGS scientists are identifying local adaptation in sage-grouse by modeling allelic variation at large numbers of single-nucleotide polymorphisms (SNPs) in relation to environmental and climate variables. This study will help identify populations that may harbor unique genetic information important for population persistence and inform future management strategies, such as translocations between populations, or management of populations based on the range-wide clusters to account for genetic variation. 


\section{Contacts}

Sara J. Oyler-McCance, USGS Fort Collins Science Center, sara_oyler-mccance@usgs.gov; 970-226-9197

Cameron L. Aldridge, USGS Fort Collins Science Center; aldridgec@usgs.gov; 970-226-9433

\section{Developing Efficient Genomic Monitoring Tools for Sage-Grouse}

Comprehensive management of species often includes monitoring programs that measure changes in population parameters. Such monitoring programs typically focus on changes in population size or vital rates. Arguably, genetic data could also be included in monitoring programs to provide a more complete picture of overall species status. To date, genetic information on sage-grouse has primarily involved examining neutral genetic variation, which is useful for documenting population connectivity and demographic processes. Recently developed genomic resources for sage-grouse have now made it possible to analyze nonneutral (that is, affecting fitness) variation, and have identified specific genes associated with potentially adaptive genetic variation (for example, local adaptations to different environments and varieties of sagebrush, disease resistance). As both types of genetic variation provide vital information for conservation and management, USGS researchers are using these new genomic resources to optimize and test a set of genomic markers that document variation at sites within the genome that are highly informative either for population processes (for example, connectivity) or for adaptation. These data could be directly linked to a range-wide sage-grouse monitoring strategy and integrated into sage-grouse population clusters to directly inform how changes in gene flow or genetic variation may affect population triggers. In addition, as technological advances have made it possible to genotype low-quality DNA samples (such as DNA from feathers) at numerous genomic markers with high reproducibility and lower cost, USGS scientists are evaluating these new protocols and analysis techniques to establish the most efficient, reliable, and transferrable genotyping standards for sage-grouse genetic monitoring. This combination of improved, more informative genomic markers with state-of-the-art analytical platforms could provide a streamlined, cost-effective tool that can be incorporated into sage-grouse monitoring programs. Further, this could improve translocation efforts by providing a more sensitive tool to detect fine-scale genetic change resulting from management actions.

\section{Contact}

Sara J. Oyler-McCance, USGS Fort Collins Science Center, sara_oyler-mccance@usgs.gov; 970-226-9197

\section{Leveraging Sage-Grouse Genomes to Inform Appropriate Sagebrush Restoration Practices}

Seeding and transplanting of sagebrush are important tools for restoration of sagebrush-steppe ecosystems. Because of the taxonomic diversity of sagebrush plants, the establishment of guidelines to assist managers in selecting ecologically appropriate plant materials is key for restoration of functioning sagebrush ecosystems that provide critical habitat for sage-grouse and other sagebrush obligates. Without guidelines, seedling success could be at risk and deleterious mismatches between sagebrush and the local ecosystem could occur. All sagebrush contains high levels of biologically active plant secondary metabolites (PSM), which function as chemical defenses to herbivory. Additionally, the chemical composition of PSM is known to vary geographically and among sagebrush taxa. Recent research on both sage-grouse species identified a family of genes linked to local dietary adaptation showing that sage-grouse possess digestive and metabolic adaptations that mitigate the effects of consuming PSM. The extent to which populations might be specialized to consuming local sagebrush varieties is unknown, however. To address this gap, USGS scientists are examining variation in these important genes associated with digestion and metabolism among sage-grouse populations that forage on different sagebrush types across the species' range. Using a targeted-resequencing approach, combined with sagebrush mapping products, the scientists are sequencing DNA from birds across the entire species range and evaluating correspondence between genetic variation and forage varieties. Understanding these associations could have important implications for restoration practices and sage-grouse population management.

\section{Contact}

Sara J. Oyler-McCance, USGS Fort Collins Science Center, sara_oyler-mccance@usgs.gov; 970-226-9197 


\section{Connecting Hubs of Genetic Exchange Across the Range of Greater Sage-Grouse-Prioritizing Corridors for Conserving Genetic Diversity}

Recent research by USGS scientists and collaborators at the USDA Forest Service and the University of Waterloo has identified hubs of genetic exchange and landscape features that affect gene flow, including identifying corridors of genetic connectivity across the contiguous range of greater sage-grouse. These efforts were made possible by collaborative effort across 11 States to collect and genotype 16,420 feathers from 2,139 leks. The products produced by this research team represent two distinctly different, yet equally important, approaches to quantifying genetic connectivity across the range of greater sagegrouse. Synthesizing these research products will identify the pathways of greatest connectivity among the hubs of genetic exchange, where genetic exchange is the greatest, and how greater sage-grouse disperse among these hubs. This research will facilitate the prioritization of areas for protection that are both (1) important hubs that maintain genetic connectivity and (2) corridors with suitable habitat and landscape features to maintain gene flow. Furthermore, this work will relate the locations of hubs and corridors to the probability of conversion to tillage agriculture in Montana, Wyoming, and the Dakotas, to the resistance and resilience of the landscape to fire and invasive grasses in the Great Basin, and to land management status across the species' range. These results can help inform ongoing management and conservation planning, including actions meant to ensure long-term connectivity for greater sage-grouse populations range wide.

\section{Contact}

Sara J. Oyler-McCance, USGS Fort Collins Science Center; sara_oyler-mccance@usgs.gov; 970-226-9197

\section{Identifying Corridors and Connectivity Within and Among Sage-Grouse Priority Areas of Conservation Rangewide}

Sage-grouse Priority Areas for Conservation (PACs) focus on targeting conservation across the species range in the areas of highest population abundance. While this PAC approach may protect the greatest number of sage-grouse, it is unclear how isolated these areas are both genetically and demographically. Specifically, any PACs that are relatively isolated or have lower genetic diversity and connectivity to neighboring PACs are at a higher risk of suffering deleterious impacts related to isolation and inbreeding. USGS scientists and collaborators at the USDA Forest Service and the University of Waterloo are developing a targeted assessment of the functional connectivity among PACs that will identify key genetic corridors among the PACs and assess levels of genetic diversity within each area. Additionally, metrics of genetic diversity and connectivity within PACs will be estimated and are another important consideration in assessing the importance of individual PACs to overall population health and sustainability.

Contact

Sara J. Oyler-McCance, USGS Fort Collins Science Center; sara_oyler-mccance@usgs.gov; 970-226-9197

\section{Integration of Genetic and Demographic Data to Assess the Relative Importance of Connectivity and Habitat in Sage-Grouse Populations}

The integration of genetic and demographic data can provide multiple levels of insight into the patterns of distribution and abundance of species. Local demographic trends and population persistence are strongly influenced by patterns of regional connectivity. However, the relative contributions of connectivity, habitat amount, and habitat quality to patterns of abundance for sage-grouse is unknown. This makes it challenging to prioritize management aimed at increasing species abundance. Using the existing rangewide genetic and demographic data, scientists from the USGS, USDA Forest Service, and University of Waterloo will assess the relative contributions of habitat and genetic connectivity to lek size and stability. Additionally, given the extent of available data the research team will assess whether the importance of connectivity varies over the range. This research can help identify which components of habitat configuration and connectivity have the largest influence on population abundance and how these factors vary regionally. These results can help facilitate targeted and regionally relevant management actions.

\section{Contact}

Sara J. Oyler-McCance, USGS Fort Collins Science Center; sara_oyler-mccance@usgs.gov; 970-226-9197 


\section{Landscape Genetic Assessment of Gunnison Sage-Grouse}

The range of the Gunnison sage-grouse, a threatened species under the Endangered Species Act, has been fragmented into geographically and genetically distinct populations. The viability of the individual populations and long-term persistence of the species may be affected by the ability of individual birds to move between populations. USGS scientists and collaborators are using genetic samples to infer connectivity across the species range and between leks within the Gunnison Basin to gain insight on which landscape or habitat features are contributing to the fragmentation of the species range. The connectivity analysis within the Basin will provide insight at a manageable scale and ultimately aims to inform current and future management scenarios by delineating corridors of movement and barriers to movement.

\section{Contact}

Sara J. Oyler-McCance, USGS Fort Collins Science Center; sara_oyler-mccance@usgs.gov; 970-226-9197

\section{Examining Adaptation in Gunnison Sage-Grouse}

The satellite populations of the Gunnison sage-grouse occupy areas with a diversity of habitat and local environmental characteristics (fig. 1). With limited gene flow between populations and potential for different selective pressures acting on each population, there is the potential for locally adapted variation. Local adaptation is important to long-term persistence of populations and pertinent to current management efforts. Pressures of changing precipitation, temperature, and land use differ among the populations, and any existing variation adapted to the unique pressures are best maintained for the long-term success of the population. USGS scientists are using genomic methods to look within each population for evidence of selection correlated with environmental variation. Identifying adaptive variation can contribute to more targeted management efforts and inform the maintenance of this variation within populations.

\section{Contact}

Sara J. Oyler-McCance, USGS Fort Collins Science Center; sara_oyler-mccance@usgs.gov; 970-226-9197

\section{Publication}

Zimmerman, S.J., Aldridge, C.L., Oh, K.P., Cornman, R.S., and Oyler-McCance, S.J., 2019, Signatures of adaptive divergence among populations of an avian species of conservation concern: Evolutionary Applications, v.12, no. 8, p. 1661-1677, https://doi.org/10.1111/eva.12825.

\section{Identification of Crucial Late-Summer Brood-Rearing and Winter Habitat for Gunnison Sage-Grouse}

Gunnison sage-grouse is considered a threatened species under the Endangered Species Act, and knowledge of resource requirements across all life states can assist conservation planning efforts. USGS and CSU scientists and colleagues are using telemetry data to develop resource selection models predicting crucial brood-rearing and winter habitat for Gunnison sage-grouse within the Gunnison Basin. These models can help improve the conservation and management of important Gunnison sage-grouse habitat, thereby enhancing the management of disturbances and increasing habitat connectivity.

\section{Contact}

Cameron L. Aldridge, USGS Fort Collins Science Center; aldridgec@usgs.gov; 970-226-9433

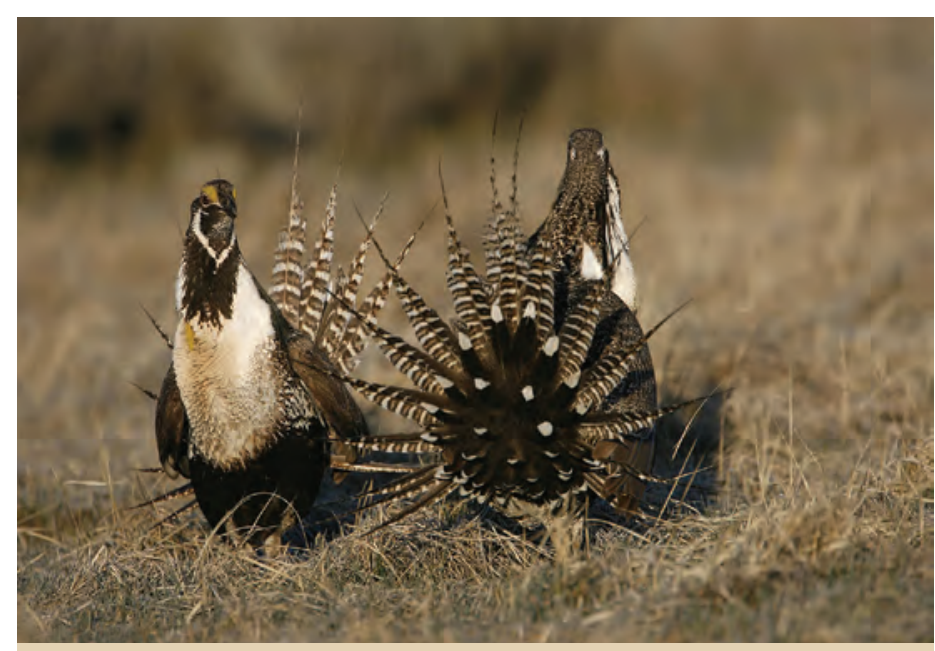

A pair of Gunnison sage-grouse. Photograph from U.S. Fish and Wildlife Service. 


\section{Landscape Variability and Gunnison Sage-Grouse Conservation}

Loss and alteration of sagebrush habitat, owing to many factors, have been identified as a primary reason for declines in Gunnison sage-grouse populations. Within the Crawford population, one of seven remaining populations, USGS scientists are evaluating the impacts of habitat variability and developing spatially explicit models to better inform Gunnison sage-grouse conservation plans. This work includes the following three pilot studies: (1) monitoring Corvid presence on the landscape and relating that to Gunnison sage-grouse habitat use and activity; (2) evaluation of annual snowpack persistence and drought impacts; and (3) analysis of Gunnison sage-grouse diets. Results will help inform decisions by the BLM; National Park Service; NRCS; USDA Forest Service; Colorado Parks and Wildlife; and Delta, Montrose, and Gunnison Counties in Colorado.

\section{Contact}

Douglas S. Ouren, USGS Fort Collins Science Center; ourend@usgs.gov; 970-226-9476

\section{Publications}

Ouren D.S., Cade, B.S., Holsinger, K.W., Siders, M.S., 2019, Are lek disturbance buffers equitable for all Gunnison sage-grouse populations?: Journal of Fish and Wildlife Management, v. 10, no. 1, p. 51-61, https://doi.org/10.3996/012018-JFWM-003.

Ouren, D.S., Ignizio, D.A., Siders, M., Childers, T., Tucker, K., and Seward, N., 2014, Gunnison sage-grouse lek site suitability modeling: U.S. Geological Survey Open-File Report 2014-1010, 18 p., https://doi.org/10.3133/ofr20141010.

\section{Assessing Habitat, Risk, and Conservation Actions for Gunnison Sage-Grouse}

The threatened Gunnison sage-grouse continues to experience declines, particularly in satellite populations. To plan conservation actions, multiple agencies need an understanding of habitat needs, risks to habitat, and the feasibility of conservation actions to improve habitat and population conditions. USGS and CSU scientists are developing habitat selection and landscape change models for Gunnison sage-grouse throughout Colorado. This research can support the BLM in evaluating the efficacy of habitat restoration and conservation actions for stabilizing and increasing Gunnison sage-grouse populations. This research includes characterizing habitat and population responses to past conservation actions and developing spatially explicit models to simulate population responses to habitat change and alternative conservation actions.

\section{Contacts}

Julie A. Heinrichs, Colorado State University, in cooperation with USGS Fort Collins Science Center; jheinrichs@usgs.gov; 970-226-9149

Steven E. Hanser, USGS Fort Collins Science Center; shanser@usgs.gov; 970-226-9309

\section{Migration Corridors for Big Game}

Across the Western United States, many ungulate herds must migrate seasonally to access resources and avoid harsh winter conditions. Because these corridors traverse vast landscapes (that is, up to 150 miles), they are increasingly threatened by roads, fencing, subdivisions and other development. Over the past decade, many new tracking studies have been conducted on migratory herds, and analytical methods have been

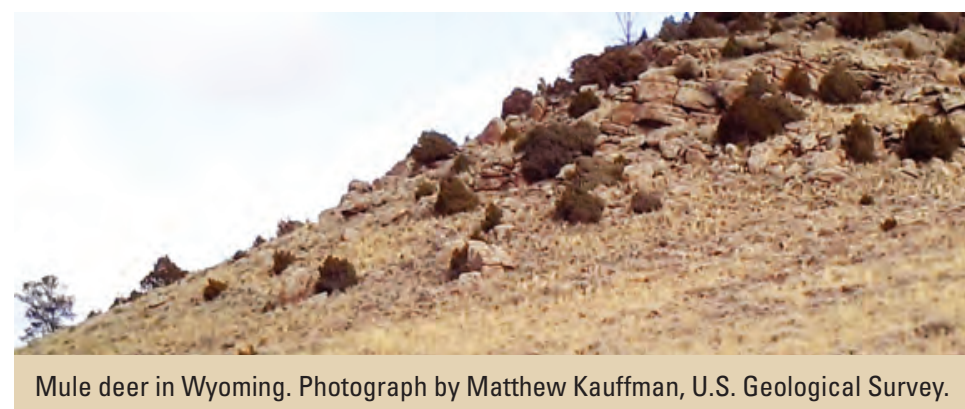
developed that allow for population-level corridors and stopovers to be mapped and prioritized. In 2018, the USGS assembled a Corridor Mapping Team to provide technical assistance to western states working to map bison (Bison bison), elk (Cervus elaphus canadensis), moose (Alces shirasi), mule deer, and pronghorn (Antilocapra Americana) corridors using existing GPS data. Based out of the Wyoming Cooperative Fish and Wildlife Research Unit, the team consists of Federal scientists, university researchers, and biologists and analysts from participating State agencies. In its first year, the team worked to develop a standardized analytical and computational method and a workflow applicable to datasets typically collected by State agencies. In 2019, the team completed analyses necessary to map a 
first batch of corridors, stopovers, and winter ranges in Arizona, Idaho, Nevada, Utah, and Wyoming. The work included a total of 26 corridors, 16 migration routes, 25 stopovers, and 9 winter ranges across these western states - often within and through sagebrush basins. Reports and associated map archives will provide a means for corridors to be considered by State and Federal transportation officials, land and wildlife managers, planners, and other conservationists working to maintain big game corridors in the western states.

\section{Contact}

Matthew J. Kauffman, USGS Wyoming Cooperative Fish and Wildlife Research Unit; mkauffman@usgs.gov; 307-766-5415

\section{Publications}

Aikens, E.O., Kauffman, M.J., Merkle, J.A., Dwinnell, S.P.H., Fralick, G.L., and Monteith, K.L., 2017, The greenscape shapes surfing of resource waves in a large migratory herbivore: Ecology Letters, v. 20, no. 6, p. 741-750, https://doi.org/10.1111/ ele. 12772 .

Courtemanch, A.B., Kauffman, M.J., Kilpatrick, S., and Dewey, S.R., 2017, Alternative foraging strategies enable a mountain ungulate to persist after migration loss: Ecosphere, v. 8, no. 6, article e01855, 16 p., https://doi.org/10.1002/ecs2.1855.

Merkle, J.A., Monteith, K.L., Aikens, E.O., Hayes, M.M., Hersey, K.R., Middleton, A.D., Oates, B.A., Sawyer, H., Scurlock, B.M., and Kauffman, M.J., 2016, Large herbivores surf waves of green-up during spring: Proceedings of the Royal Society B, v. 283, no. 1833, 8 p., https://doi.org/10.1098/rspb.2016.0456.

Merkle, J.A., Sawyer, H., Monteith, K.L., Dwinnell, S.P.H., Fralick, G.L., and Kauffman, M.J., 2019, Spatial memory shapes migration and its benefits—Evidence from a large herbivore: Ecology Letters, v. 22, no. 11, p. 1797-1805, https://doi.org/10.1111/ele.13362.

Middleton, A.D., Merkle, J.A., McWhirter, D.E., Cook, J.G., Cook, R.C., White, P.J., and Kauffman, M.J., 2018, Green-wave surfing increases fat gain in a migratory ungulate: Oikos, v. 127, no. 7, p. 1060-1068, https://doi.org/10.1111/oik.05227.

Middleton, A.D., Sawyer, H., Merkle, J.A., Kauffman, M.J., Cole, E.K., Dewey, S.R., Gude, J.A., Gustine, D.D., McWhirter, D.E., Proffitt, K.M., and White, P.J., 2020, Conserving transboundary wildlife migrations-Recent insights from the Greater Yellowstone Ecosystem: Frontiers in Ecology and the Environment, v. 18, no. 2, p. 83-91, https://doi.org/10.1002/fee.2145.

Rickbeil, G.J.M., Merkle, J.A., Anderson, G., Atwood, M.P., Beckmann, J.P., Cole, E.K., Courtemanch, A.B., Dewey, S., Gustine, D.D., Kauffman, M.J., McWhirter, D.E., Mong, T., Proffitt, K., White, P.J., and Middleton, A.D., 2019, Plasticity in elk migration timing is a response to changing environmental conditions: Global Change Biology, v. 25, no. 7, p. 2368-2381, https://doi.org/10.1111/gcb.14629.

Sawyer, H., Middleton, A.D., Hayes, M.M., Kauffman, M.J., and Monteith, K.L., 2016, The extra mile—Ungulate migration distance alters the use of seasonal range and exposure to anthropogenic risk: Ecosphere, v. 7, no. 10, article e01534, 11 p., https://doi.org/10.1002/ecs2.1534.

Wyckoff, T.B., Sawyer, H., Albeke, S.E., Garman, S.L., and Kauffman, M.J., 2018, Evaluating the influence of energy and residential development on the migratory behavior of mule deer: Ecosphere, v. 9, no. 2, article e02113, 13 p., https://doi.org/10.1002/ecs2.2113.

\section{Greater Sage-Grouse and Mule Deer Population Viability Analysis Across Scales}

Anthropogenic disturbances in sage-grouse habitats are managed at broad-scales and mid-scales (for example, the Density and Disturbance Calculation Tool (DDCT) assessment area in Wyoming). In the DDCT, surface disturbance densities are estimated within 6 kilometers of leks, and these metrics are used to inform management of sage-grouse populations. USGS and CSU scientists will use these data and sage-grouse and mule deer population data across Wyoming to do the following: (1) perform population viability analysis (PVA) in a multiscale hierarchical approach using nested lek clusters to assess response of sage-grouse populations to multiple disturbance metrics within clusters (from 1993 through 2020); and (2) use PVA to assess population responses of mule deer to these metrics at herd unit levels. Through these activities, the scientists will evaluate the effectiveness of Wyoming disturbance thresholds and investigate the efficacy of other disturbance metrics (for example fragmentation and spatial arrangement) cumulatively and individually (for example, fire versus infrastructure), enabling them to extrapolate thresholds to similar habitat conditions defined by range-wide clusters. 


\section{Contacts}

David R. Edmunds, USGS Fort Collins Science Center; dedmunds@usgs.gov; 970-226-9180

Cameron L. Aldridge, USGS Fort Collins Science Center; aldridgec@usgs.gov; 970-226-9433

\section{Publications}

Edmunds, D.R., Aldridge, C.L., O’Donnell, M.S., Monroe, A.P., 2018a, Greater sage-grouse population trends across Wyoming: The Journal of Wildlife Management, v. 82, no. 2, p. 397-412, https://doi.org/10.1002/jwmg.21386.

Edmunds, D.R., Aldridge, C.L., O’Donnell, M.S., and Monroe, A.P., 2018b. Erratum - Greater sage-grouse population trends across Wyoming: The Journal of Wildlife Management v. 82, no. 8, p. 1808, https://onlinelibrary.wiley.com/doi/10.1002/ jwmg.21560.

O’Donnell, M.S., Edmunds, D.R., Aldridge, C.L., Heinrichs, J.A., Coates, P.S., Prochazka, B.G., and Hanser, S.E., 2019, Designing multi-scale hierarchical monitoring frameworks for wildlife to support management - A sage-grouse case study: Ecosphere, v. 10, no. 9, September, article e02872, https://doi.org/10.1002/ecs2.2872.

\section{Use of Sagebrush-Reduction Treatments by Mule Deer in Wyoming}

In southwestern Wyoming, managers may apply treatments of fire, herbicide, and mechanical removal that reduce sagebrush cover to improve habitat for wildlife, including mule deer. Although much is known about vegetation responses to treatments, it is unclear whether ungulates respond to treatments (for example, increased use and fitness) and how their responses vary across treatment type, size, and context. USGS scientists are using GPS-tracking data to determine whether deer use and benefit from sagebrush treatments within their winter range and migration corridors in southwestern Wyoming. This study was facilitated by the Wyoming Landscape Conservation Initiative in collaboration with the University of Wyoming, BLM, and Wyoming Game and Fish Department.

\section{Contact}

Aaron N. Johnston, USGS Northern Rocky Mountain Science Center; ajohnston@usgs.gov; 406-994-7158

\section{Publication}

Johnston, A.N., Beever, E.A., Merkle, J.A., and Chong, G., 2018, Vegetation responses to sagebrush-reduction treatments measured by satellites: Ecological Indicators, v. 87, p. 66-76, https://doi.org/10.1016/j.ecolind.2017.12.033.

\section{Interactions of Phenology, Grazing, Hunting, and Prescribed Fire on Elk and Mule Deer in Southwestern Wyoming}

In southwestern Wyoming, land managers are interested in understanding the patterns of elk and mule deer migration, habitat use, and calving areas in the sagebrush ecosystem. USGS scientists are evaluating the likely triggers for initiation of fall migration, changes in the timing of forage during time periods crucial to elk reproduction (fall and spring), and the influence of prescribed fire, grazing, land cover, and other management activities on habitat use. This effort is leading to the identification of migration corridors, important calving areas, shifts in forage that correlate with population size, and environmental factors relevant to elk movements and habitat use that can inform future management of this important game species. USGS scientists recently examined changes in forage timing across the Western United States to help managers set population objectives and understand the role of forage in changes to ungulate numbers. This study also evaluated how well various remote sensing datasets matched on-the-ground phenocamera measurements of phenology. New studies will evaluate factors that influence the timing of spring green-up and evaluate changes in forage relative to potential changes in ungulate ecology as a result of climate change, when implementing habitat treatments. Partners include Wyoming Game and Fish Department, the BLM (Kemmerer Field Office), and the National Park Service (Fossil Butte National Monument).

\section{Contact}

Tabitha A. Graves, USGS Northern Rocky Mountain Science Center; tgraves@usgs.gov; 406-589-6645 


\section{Publication}

Mikle, N.L., Graves, T.A., and Olexa, E.M., 2019, To forage or flee-Lessons from an elk migration near a protected area:

Ecosphere, v. 10, no. 4, article e02693, https://doi.org/10.1002/ecs2.2693.

\section{Measuring Elk Density and Changes in Aggregation to Mitigate Risk of Disease in Sagebrush Ecosystems}

Wildlife managers are interested in quantifying and sometimes decreasing the density of elk to reduce disease transmission, especially where high concentrations occur, such as on winter ranges. USGS scientists assessed the use of different data sources (satellite images, GPS collars, and UAS) for monitoring the density, distribution, and locations of concentrations of elk in sagebrush and grasslands at the National Elk Refuge, WY. Researchers also evaluated the factors influencing elk contact rates on the National Elk Refuge and quantified the effect of supplemental winter feeding, harvest timing, and weather on aggregation. These two studies provide approaches to evaluate relative disease risk, such as chronic wasting disease. Next, steps include developing a framework for evaluating how adaptive management actions (in this case, the reduction of feeding) changed density and developing an open-source tool for wildlife managers to evaluate disease risk and adaptive management success for their elk populations. Partners include the Wyoming Game and Fish Department, the National Park Service (Teton National Park), and the FWS (National Elk Refuge).

\section{Contact}

Tabitha A. Graves, USGS Northern Rocky Mountain Science Center; tgraves@usgs.gov; 406-589-6645

\section{Bighorn Sheep in Sagebrush Systems}

Bighorn sheep populations are often small and fragmented. Respiratory pneumonia (M. ovipneumonia) can cause die-offs of up to 90 percent of the herd, but population effects are likely affected by habitat quality, forage productivity and phenology, population size, and genetics. USGS scientists are collaborating with partners in Grand Canyon National Park, Dinosaur National Monument, Glacier National Park, and other State and university biologists to evaluate habitat use, genetic structure, aspects of disease, and population size.

\section{Contact}

Tabitha A. Graves, USGS Northern Rocky Mountain Science Center; tgraves@usgs.gov; 406-589-6645

\section{Pronghorn Responses to Wind Farms}

New wind farms in Wyoming are planned for construction within critical winter range for pronghorn, but little is known about pronghorn responses to wind energy infrastructure and operations. In collaboration with the Wyoming Landscape Conservation Initiative, University of Wyoming, and Wyoming Game and Fish Department, USGS scientists are evaluating changes in movement and habitat use of pronghorn tracked with GPS collars from before to several years after construction of two wind farms (construction began in spring 2019). This analysis includes an assessment of long-term effects of wind farms on pronghorn through comparisons of recent use of existing wind farms by pronghorn to data on movement collected collected during and after construction of the farm from 2010-2012. Results will inform land and wildlife managers of risks for pronghorn associated with the further development of wind energy that is expected in this region.

\section{Contacts}

Matthew J. Kauffman, USGS Wyoming Cooperative Fish and Wildlife Research Unit; mkauffman@usgs.gov; 307-766-5415

Aaron N. Johnston, USGS Northern Rocky Mountain Science Center, ajohnston@usgs.gov, 406-994-7158 


\section{Ecological Disturbances of Wind Energy in Wyoming}

USGS scientists are quantifying land-surface disturbance associated with development and operation of wind facilities for the Wyoming Landscape Conservation Initiative. In this analysis, scientists are incorporating all infrastructure data associated with wind energy development, surface disturbance, and revegetation or reclamation following initial wind-facility development. Results will document the amount and pattern of disturbance over time during the development and operation of facilities in Wyoming. This research includes assessment of change in land-surface temperature, evapotranspiration, and vegetation around wind turbines. This information will be useful to developers and land managers in planning and assessing future wind projects.

Contact

Aaron N. Johnston, USGS Northern Rocky Mountain Science Center, ajohnston@usgs.gov, (406) 994-7158

\section{Using Genetic Analyses to Inform On-the-Ground Conservation for Multiple Sagebrush-Associated Wildlife Species}

Recent analyses of greater sage-grouse genetics have delineated areas of key genetic connectivity for this species and provided a prioritization tool for conservation and restoration of habitats essential for genetic exchange. While many of the seasonal migratory corridors for mule deer and pronghorn are known, key areas for genetic exchange in these species are not. USGS scientists and collaborators at the University of Wyoming are building on the growing information base of movements by marked deer and pronghorn and preliminary genetic work for both species to increase the understanding of gene flow through migration corridors. Genetically "mapping" multiple species on a landscape can help identify where conservation actions can be most beneficial to many species or where conservation for a single species might be harmful to others. Results of this study can assist in making smart conservation planning actions, maximize conservation efforts, and reduce potential conservation conflicts based on single species habitat management.

\section{Contacts}

Sara J. Oyler-McCance, USGS Fort Collins Science Center; sara_oyler-mccance@usgs.gov; 970-226-9197

Matthew J. Kauffman, USGS Wyoming Cooperative Fish and Wildlife Research Unit; mkauffman@usgs.gov; 307-766-5415

\section{Sage-Grouse as an Umbrella Species for Nongame Species of Concern in Wyoming}

A common assumption of conservation practitioners in the Western United States is that the greater sage-grouse is an umbrella species for other co-occurring wildlife. This idea, however, has not yet been empirically examined. In particular, the types of species for which sage-grouse may be an appropriate umbrella and at which spatial scales remain unclear. In Wyoming, USGS scientists are modeling overlap between suitable habitat for 52 nongame sagebrush species of conservation concern in lands managed under the Wyoming Governor's Core Area Strategy. Nongame bird abundance and reproductive success is being quantified across gradients in sage-grouse habitat quality, and before and after habitat treatments (mowing) designed to augment sage-grouse brood-rearing habitat. This research aims to inform land management that uses sage-grouse as an umbrella species and can help fine-tune other actions needed for species that are not covered under this approach.

\section{Contact}

Anna D. Chalfoun, USGS Wyoming Cooperative Fish and Wildlife Research Unit; achalfoun@usgs.gov; 307-766-6966

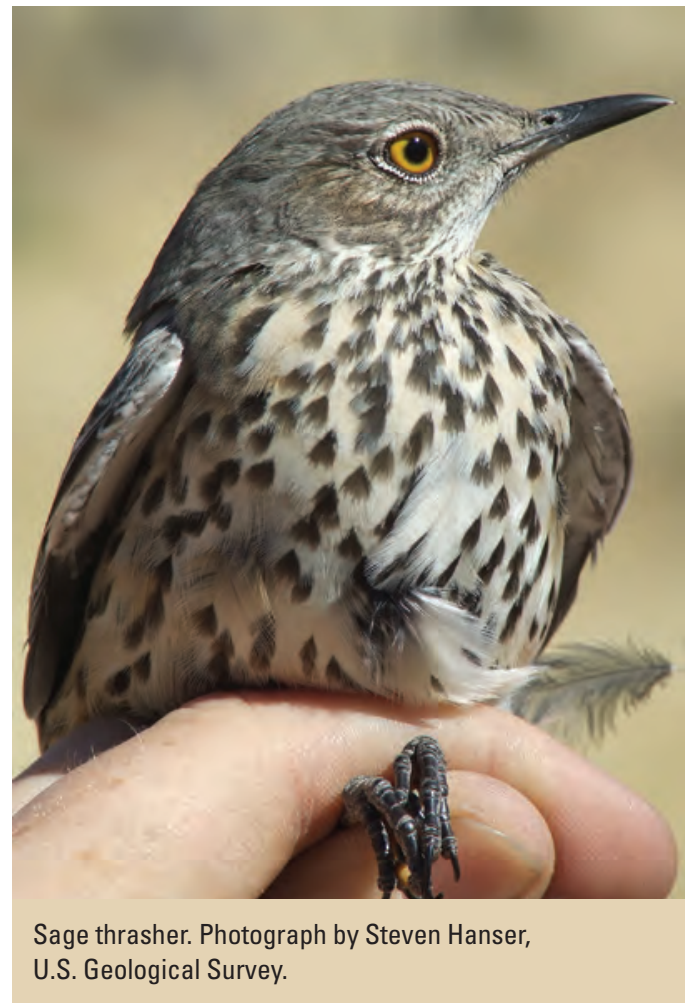




\section{Publications}

Carlisle, J.D., Chalfoun, A.D., Smith, K.T., and Beck, J.L., 2018, Nontarget effects on songbirds from habitat manipulation for greater sage-grouse-Implications for the umbrella species concept: The Condor, Ornithological Applications, v. 120, no. 2, p. 439-455, https://doi.org/10.1650/CONDOR-17-200.1.

Carlisle, J.D., Keinath, D.A., Albeke, S.E., and Chalfoun, A.D., 2018, Identifying holes in the greater sage-grouse conservation umbrella: The Journal of Wildlife Management, v. 82, no. 5, p. 948-957, https://doi.org/10.1002/jwmg.21460.

Carlisle, J.D., Stewart, D.R., and Chalfoun, A.D., 2017, An invertebrate ecosystem engineer under the umbrella of sage-grouse conservation: Western North American Naturalist, v. 77, no. 4, p. 450-463, https://doi.org/10.3398/064.077.0406.

\section{Evaluating Biodiversity of Sagebrush-Dependent Species Within Sage-Grouse Habitat—An Example from the Wyoming Basins}

Concern for declining greater sage-grouse populations has prompted an unprecedented effort by Federal, State, and private stakeholders to implement large-scale habitat management actions and identify priority areas for conservation. Given the dependency of this species on sagebrush-dominated habitat, it is likely that these sage-grouse conservation efforts could benefit other obligate sagebrush species and the ecosystems on which they depend. USGS and CSU scientists and partners are developing a modeling approach to evaluate the conservation benefits of sage-grouse to other species of conservation concern within the sagebrush biome. Across the greater Wyoming Basin's sagebrush landscape (Hanser and others, 2011), they are (1) identifying biodiversity hotspots for sagebrush obligate and associated vertebrate species of conservation concern, (2) evaluating the degree of overlap with sage-grouse priority habitats and conservation areas, and (3) evaluating the degree to which sage-grouse core areas in Wyoming capture vertebrate species biodiversity hotspots within the sagebrush biome.

\section{Contacts}

Cameron L. Aldridge, USGS Fort Collins Science Center; aldridgec@usgs.gov; 970-226-9433

Steven E. Hanser, USGS Fort Collins Science Center; shanser@usgs.gov; 970-226-9309

\section{Influence of Climatic Conditions on Reproduction of Sagebrush-Dependent Birds_Implications for Climate Vulnerability Assessments and Habitat Prioritization Efforts}

Birds in aridlands of western North America are some of the fastest declining bird species, and they are among those expected to be most affected by changing climate. USGS researchers are evaluating the reproductive vital rates of sagebrush songbirds in relation to climatic variation by leveraging several large existing datasets of nesting observations from Montana and Wyoming, archived weather station data, and gridded climate datasets. To further examine whether particular landscapes and (or) microhabitats may confer more protection in the face of increasingly more extreme weather events expected with climate change, habitat data collected remotely and at nests will be incorporated into climatic response models. Novel field efforts have also been designed to assess whether microhabitats at nests buffer ambient conditions and the associated fitness consequences. This project will provide information about songbird species that may be vulnerable to changing temperature and precipitation regimes.

\section{Contact}

Anna D. Chalfoun, USGS Wyoming Cooperative Fish and Wildlife Research Unit; achalfoun@usgs.gov; 307-766-6966 


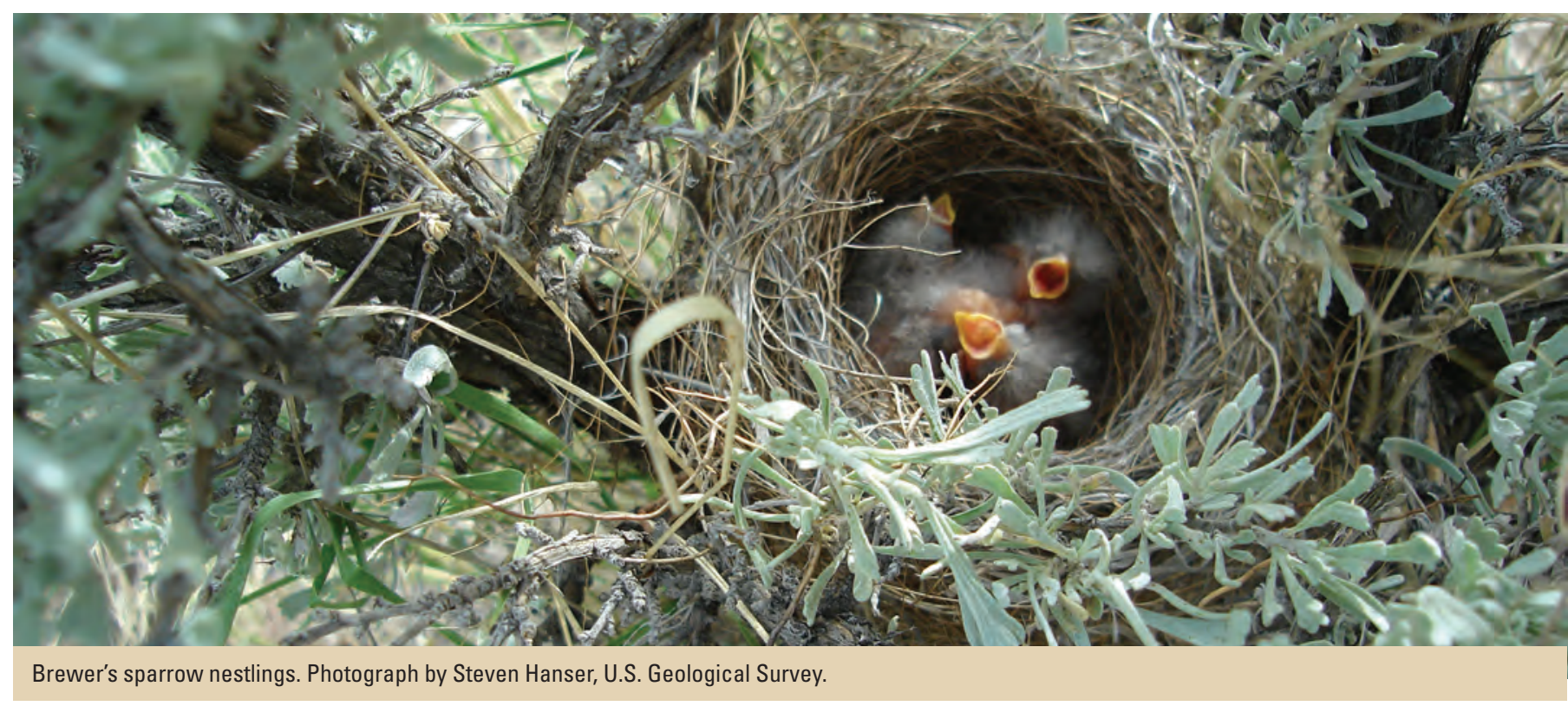

\section{Full Life-Cycle Analysis of Wyoming's Sagebrush-Obligate Songbirds}

The ecology and demography of sagebrush-obligate songbirds (Brewer's sparrow [Spizella breweri], sagebrush sparrow [Artemisiospiza nevadensis], sage thrasher [Oreoscoptes montanus]) outside of the nesting period has received little study. USGS researchers, in partnership with the Wyoming Landscape Conservation Initiative and the Wyoming Game and Fish Department, are examining postfledging habitat selection and survival, annual survival, site fidelity to breeding sites, migratory routes, and over-wintering locations. Birds will be individually marked and telemetered at sites both within and outside of natural gas fields in Sublette County in western Wyoming, which will allow for the examination of the potential effects of energy development on birds during all life stages and potential carryover effects across stages. Results from the study will address critical gaps in information about the success and demography of sagebrush songbirds during all life stages and add to information about the effects of development on them.

\section{Contact}

Anna D. Chalfoun, USGS Wyoming Cooperative Fish and Wildlife Research Unit; achalfoun@usgs.gov; 307-766-6966

\section{Developing Regional and Local Decision Support Tools for Sagebrush and Grassland Ecosystems in Northeastern Wyoming}

In and around the Thunder Basin National Grassland of northeastern Wyoming, USGS and CSU scientists and other partners are developing monitoring tools to be directly applied to inform on-the-ground conservation decision making. Using data collected by the Bird Conservancy of the Rockies through their Integrated Monitoring of Bird Conservation Regions program, the monitoring tools will be built using indices generated by combining abundance estimates of individual songbird species reliant on sagebrush or grassland habitat types. Initial focus is on developing regional monitoring tools that evaluate bird community responses to broader scale habitat attributes such as agricultural land configuration and energy development. These regional-scale tools can help provide the foundation for developing site-specific monitoring tools to directly evaluate the response of bird communities to conservation actions and agricultural practices implemented through conservation programs administered by local and nongovernmental organizations.

\section{Contacts}

Cameron L. Aldridge, USGS Fort Collins Science Center; aldridgec@usgs.gov; 970-226-9433

David R. Edmunds, USGS Fort Collins Science Center; dedmunds@usgs.gov; 970-226-9180 


\section{Modeling Habitat-Relationships of Pinyon-Juniper and Sagebrush Associated Bird Species to Inform Conifer Removal}

Management agencies are increasingly restoring sagebrush systems by removing conifers. These treatments likely result in mixed effects for wildlife species, and wildlife response may vary across the landscape. Declining sagebrush and pinyon-juniper associated bird populations highlight a clear need for tools that can help guide conifer management across the sagebrush ecosystem. To address this need, USGS researchers and partners are initiating a two-phase project to (1) develop local and landscapescale bird habitat relationship models for eight sagebrush and pinyon-juniper associated species-Brewer's sparrow, gray vireo (Vireo vicinior), green-tailed towhee (Pipilo chlorurus), juniper titmouse (Baeolophus ridgwayi), pinyon jay (Gymnorhinus), sagebrush sparrow, sage thrasher, and Townsend's solitaire (Myadestes townsendi); (2) use these models to predict current locations of high-quality habitat; and (3) develop a tool that prioritizes future conifer removal sites by quantifying the expected effects of treatments on these species. USGS researchers and partners are developing interannual abundance models at local and landscape scales using bird data collected under the Integrated Monitoring in Bird Conservation Regions (IMBCR) program (which has data from more than 199,000 point counts) and vegetation data from the IMBCR program and remotely sensed data (for example, the Shrubland Components of the National Land Cover Database), respectively. The models and optimization framework developed will increase public land managers' ability to assess conifer removal treatment effects on wildlife.

\section{Contacts}

Cameron L. Aldridge, USGS Fort Collins Science Center; aldridgec@usgs.gov; 970-226-9433

Nicholas J. Van Lanen, Colorado State University, in cooperation with USGS Fort Collins Science Center; njvanlan@colostate.edu; 970-692-1100

\section{Annotated Bibliography of Scientific Research on the Pygmy Rabbit}

Pygmy rabbits are highly reliant on big sagebrush for food and cover and are listed as a Species of Greatest Conservation Need in all States where they occur except in Washington, where they are listed as endangered. Compiling and summarizing recent science on pygmy rabbits can inform future management actions intended to protect pygmy rabbits and their habitat across the West. USGS scientists are compiling and summarizing the scientific literature on pygmy rabbits using a standard process that includes conducting a structured search of multiple reference databases for peer-reviewed journal articles and technical reports, concisely summarizing each study, and assessing the relevance of each product to a suite of priority issues that include habitat management and potential threats. The online version of the published annotated bibliography will be searchable by topic and location and include links that will lead to journal landing pages for the original publications and associated published, publicly available datasets.

\section{Contact}

Sarah K. Carter, USGS Fort Collins Science Center; skcarter@usgs.gov; 970-226-9355 


\section{Smart Energy Development in the Sagebrush Ecosystem}

The USGS is developing science and decision support tools to inform policy and management decisions about various aspects of the energy development life cycle. This is particularly important with ongoing demands for limited natural resources, and the need to be cost effective and to make decisions at the broader landscape scale. USGS scientists are working with Federal, State, and industry partners to develop the natural resource knowledge, management tools, risk assessments, and scenario planning that will form the scientific foundation for managers to use to target areas of high resource potential and low environmental concern and inform effective development.

\section{Contact}

Michael C. Duniway, USGS Southwest Biological Science

Center; mduniway@usgs.gov; 928-556-7530

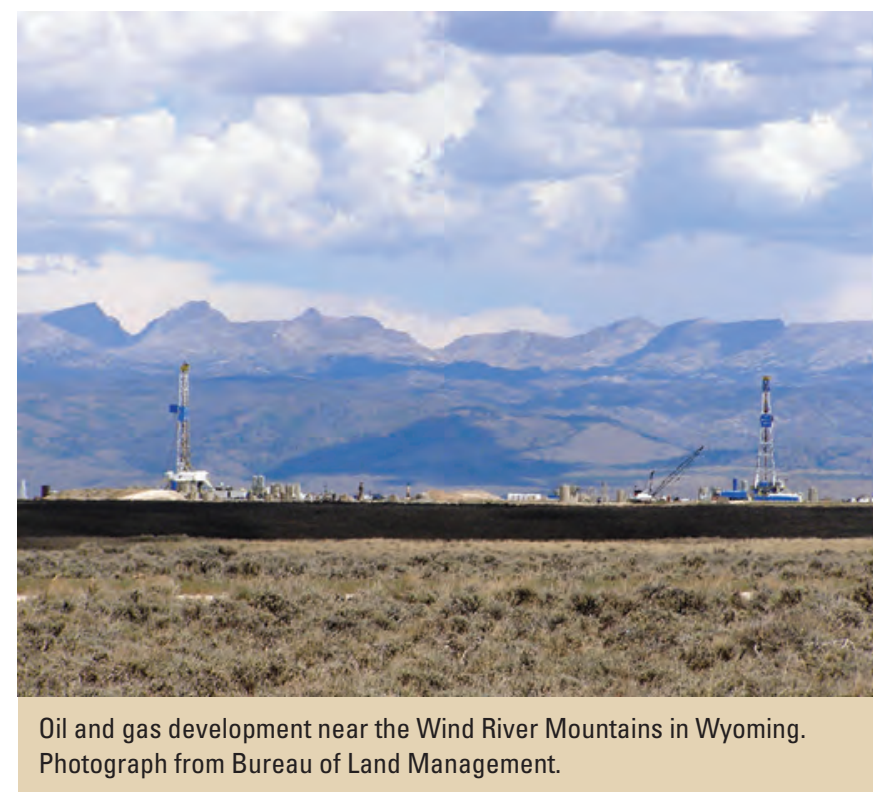

\section{Quantifying the Potential Effects of Energy Development on Wildlife and Ecosystem Services}

Energy resources are critical for a prosperous and secure nation, and a clear understanding of the potential effects of energy resource extraction is necessary for managers planning efficient and minimally impactful extraction. USGS scientists are developing and applying probabilistic models to evaluate the potential effects of energy development on landscapes, wildlife, and ecosystem services, building from the geology-based USGS assessments of undiscovered petroleum resources. Ongoing projects include (1) the development of the R package energySim and applying the model to understand potential surface disturbance associated with fully extracting technically recoverable continuous petroleum resources across the United States, and (2) using the energy footprint model to evaluate the effects of sage-grouse core area policy on landscape patterns and wildlife habitat and to understand potential changes in sediment erosion under alternative energy development scenarios.

\section{Contacts}

Monica A. Dorning, USGS Geosciences and Environmental Change Science Center; mdorning@usgs.gov; 352-264-3499

Seth S. Haines, USGS Central Energy Resources Science Center; shaines@usgs.gov; 303-236-5709

Jay E. Diffendorfer, USGS Geosciences and Environmental Change Science Center; jediffendorfer@usgs.gov; 303-236-5369

\section{Publications}

Dorning, M.A., Garman, S.L., Diffendorfer, J.E., Semmens, D.J., Hawbaker, T.J., and Bagstad, K.J., 2017, Oil and gas development influences big-game hunting in Wyoming: The Journal of Wildlife Management, v. 81, no. 3, p. 379-392, https://doi.org/10.1002/jwmg.21205.

Garman, S.L., 2017, A simulation framework for assessing physical and wildlife impacts of oil and gas development scenarios in southwestern Wyoming: Environmental Modeling \& Assessment, v. 23, no. 1, p. 39-56, https://doi.org/10.1007/s10666-017$9559-1$.

Haines, S.S., Diffendorfer, J.E., Balistrieri, L., Berger, B., Cook, T., DeAngelis, D., Doremus, H., Gautier, D.L., Gallegos, T., Gerritsen, M., Graffy, E., Hawkins, S., Johnson, K.M., Macknick, J., McMahon, P., Modde, T., Pierce, B., Schuenemeyer, J.H., Semmens, D., Simon, B., Taylor, J., and Walton-Day, K., 2014, A framework for quantitative assessment of impacts related to energy and mineral resource development: Natural Resources Research, v. 23, no. 1, p. 3-17, https://doi.org/10.1007/s11053-013-9208-6.

Martinez, C., 2017, energySim—An R package: U.S. Geological Survey software release, https://doi.org/10.5066/F7X34VZF. 


\section{Mechanisms Underlying Sagebrush-Obligate Songbird Responses to Natural Gas Development}

Extraction for energy resources can have consequences for wildlife populations, including sagebrush-obligate songbirds. USGS research initiated in 2008 demonstrated decreased sagebrush songbird (Brewer's sparrow, sagebrush sparrow, and sage thrasher) abundance and nesting success with surrounding habitat loss owing to natural gas development in western Wyoming. The predominant source of nest losses was predation, and subsequent video camera data revealed that the main nest predators were rodents (deer mice [Peromyscus spp.], chipmunks [Tamias spp.], and ground squirrels [Spermophilus spp.]). The abundance of most rodent species increased with natural gas development, and particularly the amount of surrounding reclaimed (re-seeded post soil disturbance) area, which was associated with higher rates of nest predation. New experiments are underway to examine the relative role of food availability and nest predation on songbird nesting success, and how these relationships change with development. Understanding the mechanisms underlying wildlife responses to energy development and other forms of human-induced habitat change are critical to informing targeted and effective management regimes.

\section{Contact}

Anna D. Chalfoun, USGS Wyoming Cooperative Fish and Wildlife Research Unit; achalfoun@usgs.gov; 307-766-6966

\section{Publications}

Hethcoat, M.G., and Chalfoun, A.D., 2015a, Energy development and avian nest survival in Wyoming, USA—A test of a common disturbance index: Biological Conservation, v. 184, p. 327-334, https://doi.org/10.1016/j.biocon.2015.02.009.

Hethcoat, M.G., and Chalfoun, A.D., 2015b, Towards a mechanistic understanding of human-induced rapid environmental change-A case study linking energy development, nest predation and predators: Journal of Applied Ecology, v. 52, no. 6, p. 1492-1499, https://doi.org/10.1111/1365-2664.12513.

Sanders, L.E., and Chalfoun, A.D., 2018, Novel landscape elements within natural gas fields increase densities but not fitness of an important songbird nest predator: Biological Conservation v. 228, p. 132-141, https://doi.org/10.1016/j. biocon.2018.10.020.

Sanders, L.E., and Chalfoun, A.D., 2019, Mechanisms underlying increased nest predation in natural gas fields—A test of the mesopredator release hypothesis: Ecosphere, v. 10, no. 5, article e02738, 17 p., https://doi.org/10.1002/ecs2.2738.

\section{Distance Effects of Oil and Gas Field Infrastructure on Pygmy Rabbits}

Pygmy rabbits rely year-round on sagebrush for both food and cover and are sensitive to oil and gas development. They are a species of conservation concern in several States and have been petitioned for listing under the Endangered Species Act across their range. In Wyoming, USGS scientists are investigating the influence of oil and gas development on pygmy rabbit populations. This research will help determine the distribution of pygmy rabbit habitat relative to ongoing oil and gas well development and how far from the nearest well pad, road, or pipelines pygmy rabbit presence and abundance may be affected. This information can help inform the development of future oil and gas fields and reduce the effects of disturbance on pygmy rabbits and other sagebrush obligate wildlife.

\section{Contacts}

Sarah K. Carter, USGS Fort Collins Science Center; skcarter@usgs.gov; 970-226-9355

Patrick Anderson, USGS Fort Collins Science Center; andersonpj@usgs.gov; 970-226-9488 


\section{Publications}

Germaine, S.S., Assal, T., Freeman, A. and Carter, S.K., 2020. Distance effects of gas field infrastructure on pygmy rabbits in southwestern Wyoming. Ecosphere, v. 11, no. 8, article e03230, https://doi.org/10.1002/ecs2.3230.

Germaine, S.S., Carter, S.K., Ignizio, D.A., and Freeman, A.T., 2017, Relationships between gas field development and the presence and abundance of pygmy rabbits in southwestern Wyoming. Ecosphere v. 8, no. 5, article e01817, https://doi.org/10.1002/ecs2.1817.

\section{Bumble Bees in the Sagebrush Ecosystem}

Bumble bees pollinate a broad diversity of flowering plants in the sagebrush ecosystem and are considered keystone species. The Western bumble bee (Bombus occidentalis) has been declining in recent years and will be considered for listing under the Endangered Species Act. USGS scientists have assessed information gaps, including the identification of areas with very limited sampling, and developed a protocol and sample design to help address science needs. Researchers are beginning a new project with the FWS to assess relationships between stressors and occupancy to support the upcoming Species Status Assessment. In addition, little is known about bumble bee communities relative to the diversity of flowering plants, or which plant species are preferred by bumble bees, especially in sagebrush systems. USGS scientists are currently using occupancy modeling and other approaches to assess these questions on BLM lands in eastern Montana and in South Dakota.

\section{Contact}

Tabitha A. Graves, USGS Northern Rocky Mountain Science Center; tgraves@usgs.gov; 406-589-6645

\section{Publication}

Graves, T.A, Janousek, W.M., Gaulke, S., Nicholas, A., Keinath, D., Bell, C., Cannings, S., Hatfield, R., Heron, J.M., Koch, J.B. Loffland, H.L., Richardson, L.L., Rohde, A. Rykken, J., Strange, J.P., Tronstead, L., and Sheffield, C ., 2020, Western bumble bee-Declines in the continental United States and range-wide information gaps. Ecosphere, v. 11, no. 6, June, article e03141, https://doi.org/10.1002/ecs2.3141.

\section{Pollinator Assessment and Conservation}

USGS scientists are developing methods to detect Western, Franklin's (Bombus franklini), and Yellow-faced bumble bees (B. vosnesenskii) using environmental DNA (eDNA). eDNA offers a potential noninvasive sampling method that could help characterize the occupancy status and spatial distribution of these bumble bees throughout their range. In addition, they are using landscape genetic techniques, such as maximum entropy, resistance, and structural equation models - combined with landscapescale habitat modeling - to answer questions about decreases in the abundance and range of the Western bumble bee. Results provide insight into current and potential threats to these native pollinators and inform conservation actions that can be taken to protect remaining populations. Results also provide information directly applicable to the development of a Species Status Assessment for the Western bumble bee.

Contact

David S. Pilliod, USGS Forest and Rangeland Ecosystem Science Center; dpilliod@usgs.gov; 208-426-5202 


\section{Restoring Sandberg Bluegrass Communities to Protect Packard's Milkvetch Habitat and Reduce Fuel Loadings}

Packard's milkvetch (Astragalus packardiae) is a very rare plant of the sagebrush steppe ecosystem that is found only in northeastern Payette County in southwestern Idaho. USGS researchers are teaming up with the BLM to help inform the restoration of Sandberg bluegrass (Poa secunda) and other native species in areas adjacent to Packard's milkvetch habitat. Restoring surrounding areas may help to ensure long-term viability of remaining Packard's milkvetch populations by supporting native pollinator habitat and reducing fuel loadings and associated fire risk. USGS scientists will collect and analyze data that can help the BLM determine restoration effects and success.

\section{Contact}

Douglas J. Shinneman, USGS Forest and Rangeland Ecosystem Science Center; dshinneman@usgs.gov; 208-426-5206

\section{Vulnerability of Aspen Stands in Sagebrush Ecosystems to Altered Fire and Climate Dynamics}

In the northern Great Basin, lower-elevation aspen (Populus tremuloides) forests often occur as small, isolated patches within sagebrush-dominated landscapes. Although aspen is a fire-adapted species, if fire is too frequent at low elevations it could negatively affect aspen survival, especially when combined with impacts from exotic plants, worsening droughts, or other stresses, such as insects and disease. This study investigates how these changing disturbance and climate conditions, such as drought, are affecting lower-elevation aspen forests in the northern Great Basin using a combination of field sampling, geographic analysis, remote sensing, and statistical modeling. The primary outcomes are a regional assessment of where and under what conditions lower-elevation aspen are most vulnerable to undesirable ecological change or potential decline in forest health. The tools and information from this research will have direct and timely uses for land managers working to conserve aspen forests in the Great Basin and surrounding regions.

\section{Contact}

Douglas J. Shinneman, USGS Forest and Rangeland Ecosystem Science Center; dshinneman@usgs.gov; 208-426-5206

\section{Effects of Livestock Grazing on Greater Sage-Grouse}

Cattle grazing may be the most common land use within sage-grouse habitat. The USGS is working with ranchers and university and agency collaborators to quantify the effects of cattle grazing on sage-grouse through a suite of replicated landscape-scale experiments. This research is evaluating the effects of different cattle grazing regimes on survival, site fidelity, habitat selection, chick diet, and reproductive traits of greater sage-grouse. The experimental study uses replicate study sites across Idaho that receive either no grazing, 30 - to 40-percent grass offtake during spring only, or 30- to 40-percent grass offtake during spring and fall. Researchers are also measuring the effects of these grazing treatments on vegetation (sage-grouse habitat features), arthropod abundance, and abundance of other sagebrush steppe birds. This research can help inform land management decisions related to the amount and timing of grazing practices that are compatible with sage-grouse habitat needs.

\section{Contact}

Courtney J. Conway, USGS Idaho Cooperative Fish and Wildlife Research Unit; cconway@usgs.gov; 208-885-6176

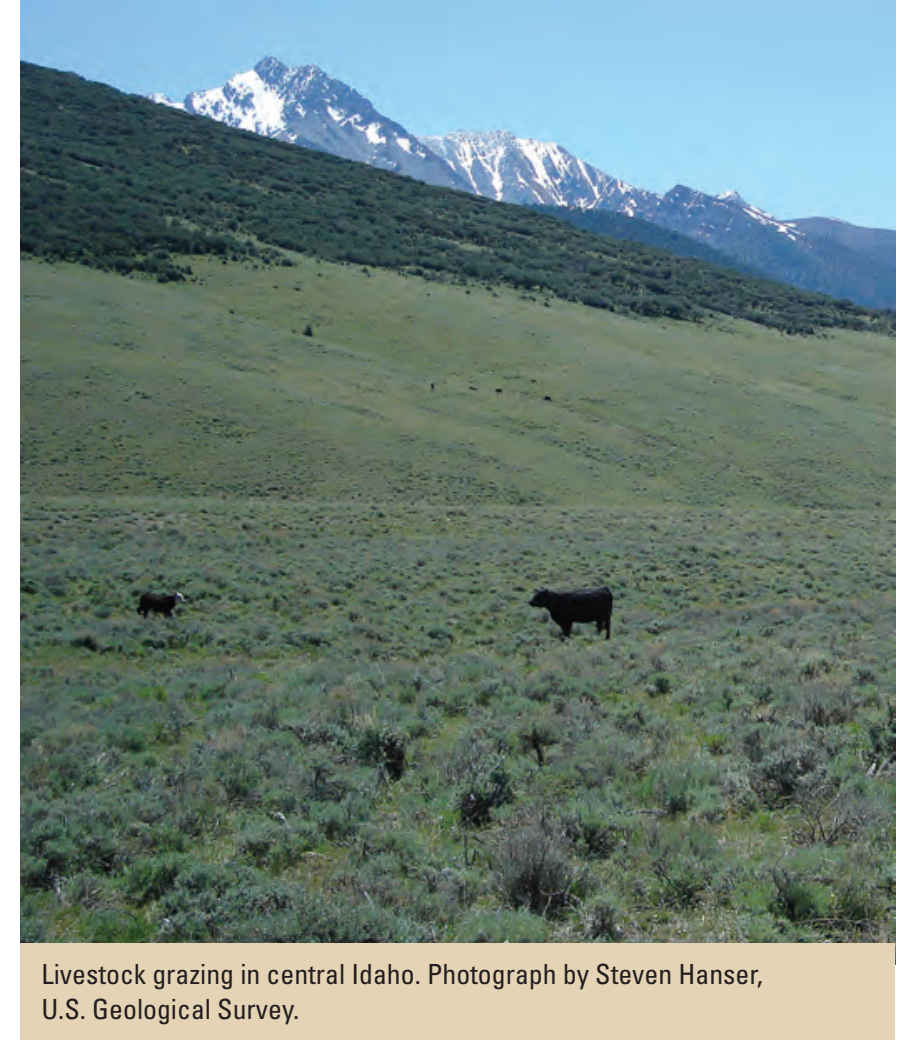




\section{Effects of Invasive Cheatgrass on Sage-Grouse in Nevada}

Invasion of sagebrush shrublands by cheatgrass is one of the primary threats to greater sage-grouse in the Great Basin. The USGS has multiple ongoing studies throughout the Great Basin evaluating the effects of cheatgrass on greater sage-grouse habitat selection and population vital rates. Researchers have measured cheatgrass abundance and height at radio- and GPSmarked sage-grouse locations and at random available locations. In a collaborative effort, the USGS and others are incorporating these cheatgrass data in nest-site selection and nest-survival models for northwestern Nevada. Additionally, researchers are analyzing the effects of cheatgrass on selection and survival within the brood-rearing life phase in study areas across Nevada. This work can provide land managers with information about the relative effects of cheatgrass at multiple life stages, improving the ability to effectively target management and mitigation efforts.

\section{Contacts}

Peter S. Coates, USGS Western Ecological Research Center; pcoates@usgs.gov; 530-669-5073

Michael L. Casazza, USGS Western Ecological Research Center; mike_casazza@usgs.gov; 530-669-5075

\section{Publication}

Lockyer, Z.B., Coates, P.S., Casazza, M.L., Espinosa, S., and Delehanty, D.J., 2015, Nest-site selection and reproductive success of greater sage-grouse in a fire-affected habitat of northwestern Nevada: The Journal of Wildlife Management, v. 79, no. 5, p. 785-797, https://doi.org/10.1002/jwmg.899.

\section{Implications of Anthropogenic Activities on Greater Sage-Grouse Populations in Nevada}

The USGS is conducting research on a broad geographical scale at multiple study sites to understand the long- and shortterm effects of anthropogenic disturbance caused by wind turbines, gold mining, geothermal energy production, hydraulic fracturing for oil, and transmission line development on greater sage-grouse habitat selection, population vital rates, and movement patterns. This research can provide resource managers with information and tools needed to develop guidelines for projects that strive to minimize negative effects on greater sage-grouse.

\section{Contact}

Peter S. Coates, USGS Western Ecological Research Center; pcoates@usgs.gov; 530-669-5073

\section{Understanding How Changes in Traffic Volume May Affect Sage-Grouse Population Dynamics Across Scales in Wyoming}

Declines in greater sage-grouse populations at leks have been observed in relation to transportation features, with leks becoming extirpated within 7.5 kilometers of interstate highways (for example, I-80 in Wyoming). Habitat studies have also shown sage-grouse avoidance of seasonal habitat (functional habitat loss) near roads or in areas with high road densities and associated development. USGS researchers and partners are working to investigate how transportation activities may drive changes in sage-grouse populations, using annually time-stamped transportation from the Wyoming Department of Transportation and sage-grouse population data from the Wyoming Game and Fish Department. Researchers are investigating sage-grouse population responses to annual average daily traffic monitored from 1970 to 2017 (about 20,000 monitoring locations). These approaches will allow identification of potential traffic volume thresholds that affect sage-grouse across hierarchies ranging from individual leks through groups of leks nested within population clusters, and identify potential scaled effects of roads on sagegrouse populations.

\section{Contacts}

Cameron L. Aldridge, USGS Fort Collins Science Center; aldridgec@usgs.gov; 970-226-9433

Michael O’Donnell, USGS Fort Collins Science Center; odonnellm@usgs.gov; 970-226-9407 


\section{Effects of Pinyon and Juniper on Sage-Grouse Movement, Distribution, and Survival}

Conifer expansion into sagebrush shrublands is a major threat to sage-grouse habitat. Information is needed to understand the mechanisms leading to the decline and extirpation of sage-grouse in areas of conifer expansion. USGS scientists are using telemetry from multiple field sites across Nevada and northeastern California collected over a 10-year period, coupled with high-resolution conifer maps, to investigate the influences of trees within sagebrush shrubland on sage-grouse distribution and survival. Results from these analyses indicate that encroachment of sparsely distributed conifers into wet, high-elevation productive habitats strongly selected by sage-grouse may be an ecological trap (see studies listed below). Increased predation facilitated by trees serving as perch or nest site subsidies for raptors and ravens may explain this finding; subsequent analyses will identify causes and consequences of ecological traps at different sage-grouse life-history phases in relation to pinyon and juniper. This research provides greater understanding of the risk of conifer encroachment into sagebrush habitat to sage-grouse, and can help inform conifer removal projects.

\section{Contact}

Peter S. Coates, USGS Western Ecological Research Center; pcoates@usgs.gov; 530-669-5073

\section{Publications}

Coates, P.S., Prochazka, B.G., Ricca, M.A., Gustafson, K.B., Ziegler, P., and Casazza, M.L., 2017, Pinyon and juniper encroachment into sagebrush ecosystems impacts distribution and survival of greater sage-grouse: Rangeland Ecology \& Management, v. 70, no. 1, p. 25-38, https://doi.org/10.1016/j.rama.2016.09.001.

Prochazka, B.G., Coates, P.S., Ricca, M.A., Casazza, M.L., Gustafson, K.B., and Hull, J.M., 2017, Encounters with pinyonjuniper influence riskier movements in greater sage-grouse across the Great Basin: Rangeland Ecology \& Management, v. 70, no. 1, p. 39-49, https://doi.org/10.1016/j.rama.2016.07.004.

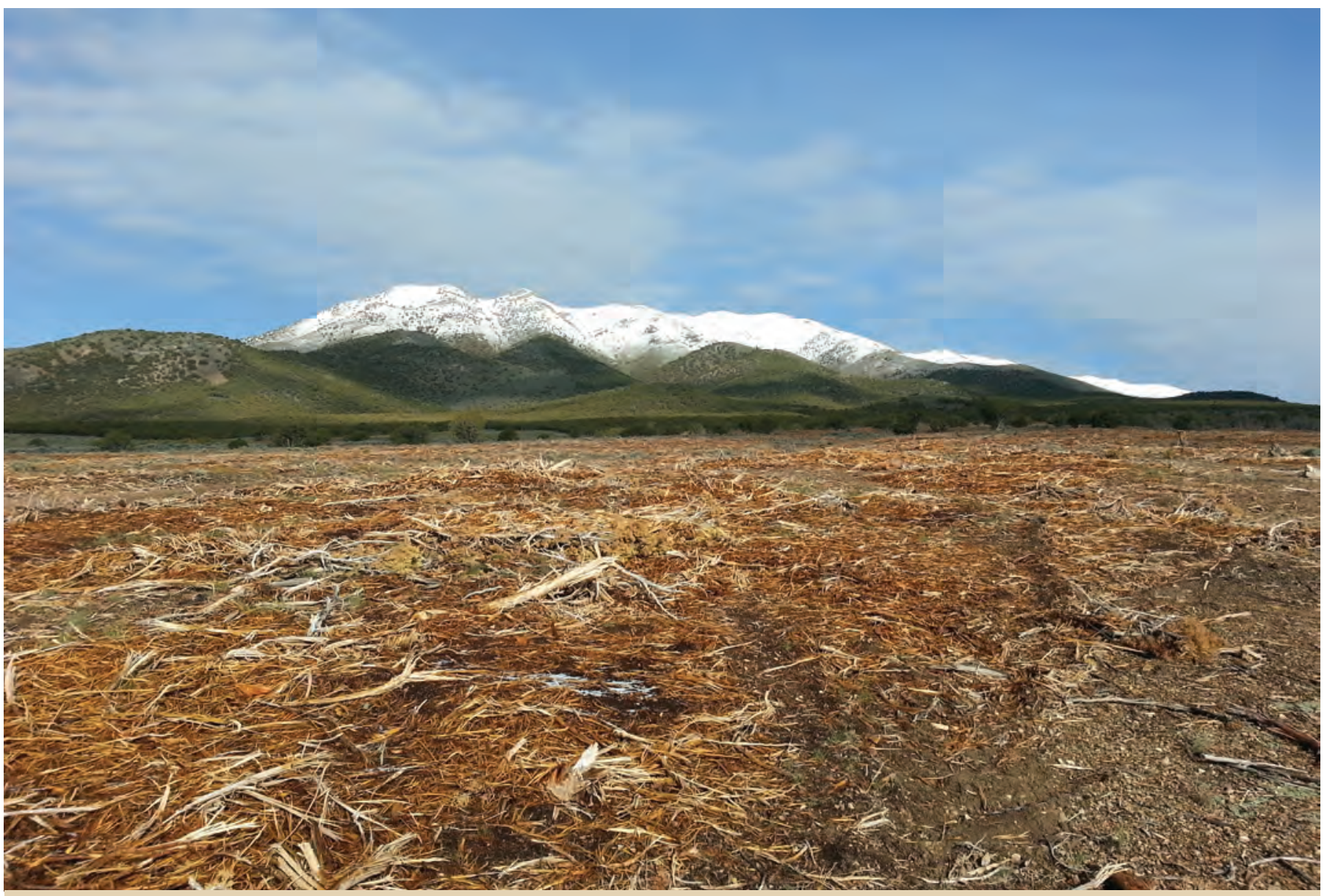

Area mechanically treated to remove junipers in central Utah. Photograph by Steven Hanser, U.S. Geological Survey. 


\section{Predation Effects on Sage- Grouse Population Dynamics}

Information about sage-grouse predation is incomplete. The USGS has initiated a large-scale investigation of predation effects and underlying ecological drivers of predation at sites located throughout California and Nevada. Through use of nest videography, avian predator surveys, habitat assessment, geospatial analysis, and telemetry- and GPS-based sage-grouse monitoring, USGS and Idaho State University scientists are evaluating how habitat composition, anthropogenic impacts, and other spatial and temporal processes influence nest predation rates, as well as age- and sex-specific survival rates, and the

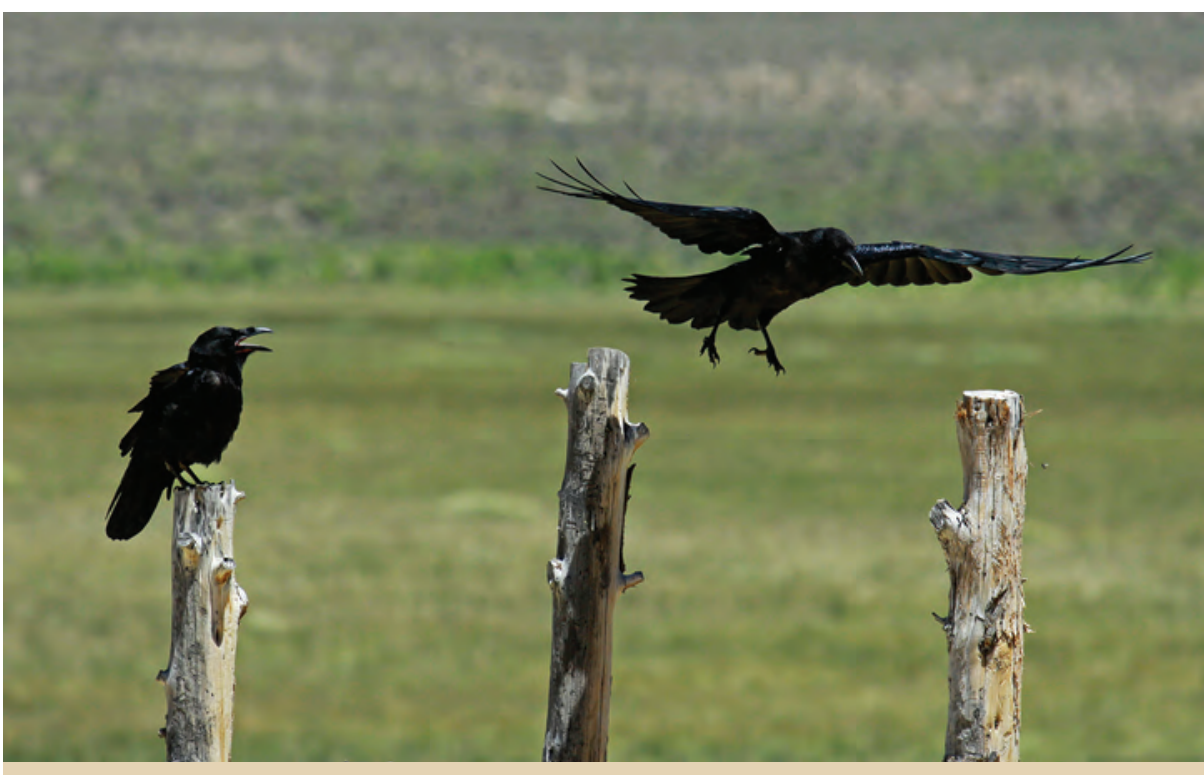

Two common ravens in Nevada. Photograph by Tatiana Gettelman, U.S. Geological Survey. distribution of predators themselves.

Results from these site-level studies help inform the development of sage-grouse management plans aimed at reducing predation impacts on sage-grouse populations.

\section{Contact}

Peter S. Coates, USGS Western Ecological Research Center; pcoates@usgs.gov; 530-669-5073

\section{Publications}

Coates, P.S., Brussee, B.E., Howe, K.B., Gustafson, K.B., Casazza, M.L., and Delehanty, D.J., 2016, Landscape characteristics and livestock presence influence common ravens-Relevance to greater sage-grouse conservation: Ecosphere, v. 7, no. 2, article e01203, 20 p., https://doi.org/10.1002/ecs2.1203.

Coates, P.S., Howe, K.B., Casazza, M.L., and Delehanty, D.J., 2014, Common raven occurrence in relation to energy transmission line corridors transiting human-altered sagebrush steppe: Journal of Arid Environments, v. 111, p. 68-78, https://doi.org/10.1016/j.jaridenv.2014.08.004.

Lockyer, Z.B., Coates, P.S., Casazza, M.L., Espinosa, S., and Delehanty, D.J., 2013, Greater sage-grouse nest predators in the Virginia Mountains of northwestern Nevada: Journal of Fish and Wildlife Management, v. 4, no. 2, p. 242-255, https://doi.org/10.3996/122012-JFWM-110R1.

McIntire, S.E., Rabon, J.C., Coates, P.S., Ricca, M.A., and Johnson, T.N., 2020, Greater sage-grouse chick killed by Great Basin gopher snake: Western North American Naturalist, v. 80, no. 1, article 7, https://scholarsarchive.byu.edu/wnan/vol80/iss1/7.

\section{Raven Density and Management Across the Great Basin}

Resource managers in the Great Basin region have become increasingly concerned about the implications of increasing predation on sage-grouse nest success and seek to understand where Common raven (Corvus corax) occur and why they occur in numbers high enough to be detrimental to sage-grouse. USGS scientists and collaborators are conducting research to inform adaptive management of raven abundance under the broader goal of reducing predator impacts on sage-grouse populations. Initial information products describe establishment of reproducible survey protocols for estimating raven densities in sagegrouse habitats and in sagebrush ecosystems within the broader Great Basin region of the southwestern United States. In a recent publication, scientists generated spatially explicit maps that integrated high raven occurrence based on anthropogenic subsidies with priority sage-grouse habitat across the Great Basin to help inform future management efforts to reduce predation impacts on sage-grouse populations. 


\section{Contact}

Peter S. Coates, USGS Western Ecological Research Center; pcoates@usgs.gov; 530-669-5073

\section{Publications}

Coates, P.S., O’Neil, S.T., Brussee, B.E., Ricca, M.A., Jackson, P.J., Dinkins, J.B., Howe, K.B., Moser, A.M., Foster, L.J., and Delehanty, D.J., 2020, Broad-scale impacts of an invasive native predator on a sensitive native prey species within the shifting avian community of the North American Great Basin: Biological Conservation, v. 243, article 108409, https://doi.org/10.1016/j.biocon.2020.108409.

O’Neil, S.T., Coates, P.S., Brussee, B.E., Jackson, P.J., Howe, K.B., Moser, A.M., Foster, L.J., and Delehanty, D.J., 2018, Broad-scale occurrence of a subsidized avian predator-Reducing impacts of ravens on sage-grouse and other sensitive prey: Journal of Applied Ecology, v. 55, no. 6, p. 2641-2652, https://doi.org/10.1111/1365-2664.13249.

\section{Effects of Raven Removal on Nest Survival and Population Growth Rates of Greater Sage-Grouse}

Common raven populations are increasing drastically within sagebrush ecosystems, largely as a result of increased anthropogenic resources. Ravens are effective sage-grouse nest predators and increased raven numbers have been shown to decrease sage-grouse nest survival. Wildlife and land management agencies have considered the removal of ravens as an option to increase sage-grouse productivity in many areas throughout the Western United States. However, the effects of raven removal on sage-grouse nest survival, productivity, and population growth rates are unclear. USGS scientists and collaborators are estimating the effects of raven removal on greater sage-grouse population dynamics using 8 to 10 years of telemetry data. This research will help gain better understanding of the effects of ravens on sage-grouse and inform future management efforts to reduce predation impacts on sage-grouse populations.

\section{Contact}

Peter S. Coates, USGS Western Ecological Research Center; pcoates@usgs.gov; 530-669-5073

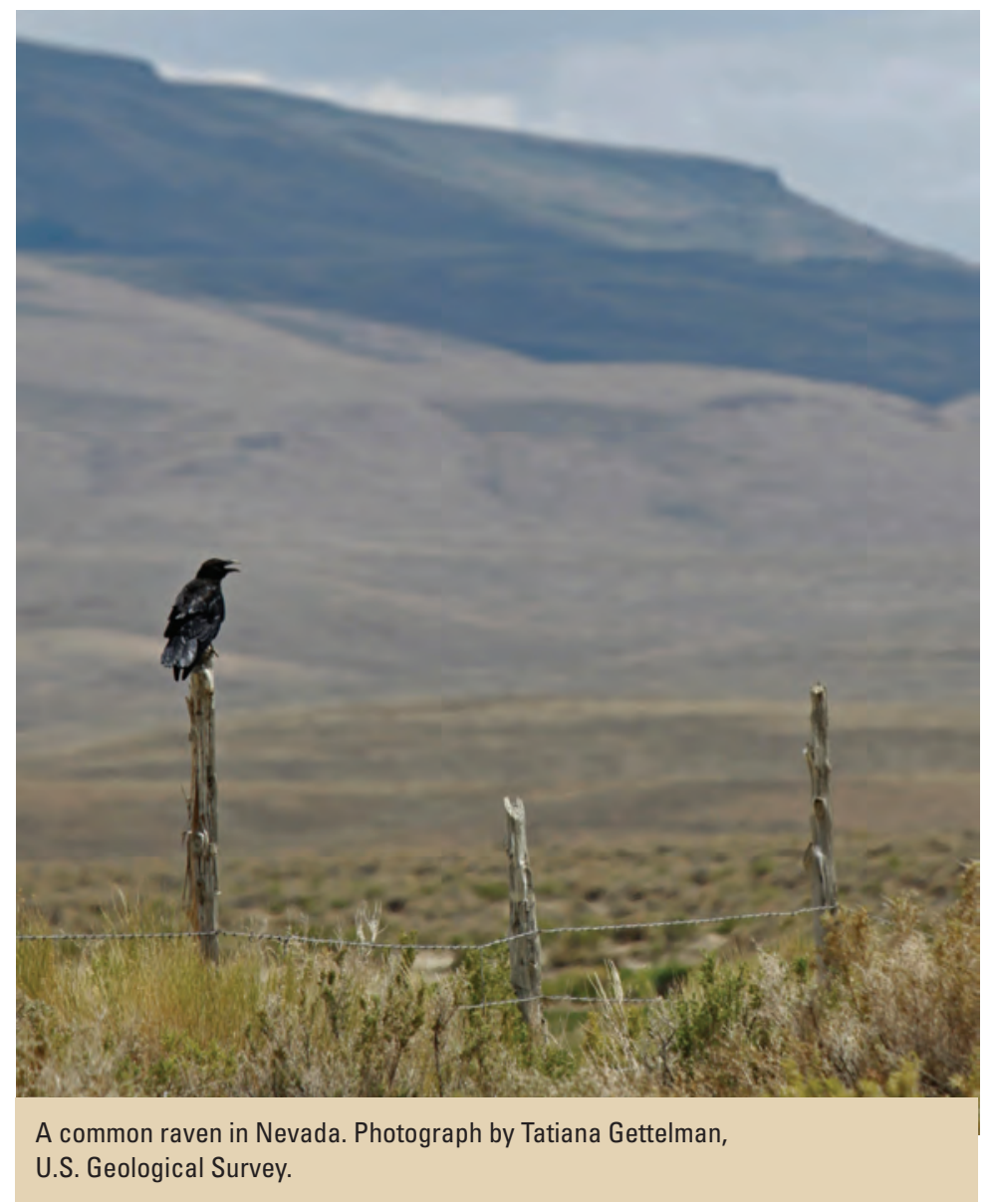

\section{Decision Support Tool for Managing Expanding Common Raven Populations and Assessing Risks to Sensitive Species}

Common ravens are a generalist predator expanding in population and abundance, largely associated with the expansion of human enterprise across western North America. An increasing body of scientific evidence points to the important role that ravens play in limiting population growth of sage-grouse and other sensitive species. A team of USGS scientists has proposed three primary objectives to leverage extensive existing field datasets of ravens and sage-grouse populations within the Great Basin to produce useful decision support tools for multiscale assessments and management plans by State and Federal agencies. First, density-surface maps of raven occupancy and density will be created to assist managers conducting desktop analyses 
for (1) estimating raven densities across different spatial scales, (2) identifying anthropogenic factors that influence density, and (3) estimating spatially explicit changes in population density through time. Second, the team will continue working to identify patterns in sage-grouse population growth rates relative to raven density, wildfire, and climatic conditions across the Great Basin as well as to identify the demographic processes that explain variation in population growth using a subset of areas with extensive sage-grouse telemetry data (17 field sites across the Great Basin). Finally, the team will provide a rapid survey protocol for ravens and demonstrate the use of these scientific products in an adaptive management framework for State and Federal wildlife agencies.

\section{Contacts}

Peter S. Coates, USGS Western Ecological Research Center; pcoates@usgs.gov; 530-669-5073

Mark A. Ricca, USGS Western Ecological Research Center; mark_ricca@usgs.gov; 530-669-5068

Shawn T. O’Neil, USGS Western Ecological Research Center; soneil@usgs.gov; 530-669-5073

\section{Plant Community Composition and Vegetation Structure in Core Sage-Grouse Habitats}

The composition and abundance of plant species in sagebrush ecosystems are important habitat attributes for sage-grouse; however, the combined effects of altered disturbance regimes (for example, fire) and biological invasions (for example, cheatgrass) are affecting plant community dynamics, and these effects are anticipated to accelerate with warmer climatic conditions. The goal of this project is to understand how these interacting change agents may influence plant community dynamics in core sage-grouse habitat areas. USGS scientists and university collaborators are integrating field measurements of plant community structure and soil conditions with ecological simulation models to assess the influence of changing climate and other disturbance regimes on the plant species composition and vegetation structure of sagebrush-dominated ecosystems. Outcomes of the project can help inform develop potential climate adaptation strategies.

\section{Contact}

John B. Bradford, USGS Southwest Biological Science Center; jbradford@usgs.gov; 928-556-7300

\section{Publications}

Martyn, T.E., Bradford, J.B., Schlaepfer, D.R., Burke, I.C., and Lauenroth, W.K., 2016, Seed bank and big sagebrush plant community composition in a range margin for big sagebrush: Ecosphere, v. 7, no. 10, article e01453, https://doi.org/10.1002/ ecs2.1453.

Pennington, V.E., Bradford, J.B., Palmquist, K.A., Renne, R.R., and Lauenroth, W.K., 2019, Patterns of big sagebrush plant community composition and stand structure in the Western United States: Rangeland Ecology \& Management, v. 72, no. 3, p. 505-514, https://doi.org/10.1016/j.rama.2018.11.013.

Pennington, V.E., Palmquist, K.A., Bradford, J.B., and Lauenroth, W.K., 2017, Climate and soil texture influence patterns of forb species richness and composition in big sagebrush plant communities across their spatial extent in the western U.S.: Plant Ecology, v. 218, p. 957-970, https://doi.org/10.1007/s11258-017-0743-9.

Pennington, V.E., Schlaepfer, D.R., Beck, J.L., Bradford, J.B., Palmquist, K.A., and Lauenroth, W.K., 2016, Sagebrush, greater sage-grouse, and the occurrence and importance of forbs: Western North American Naturalist, v. 76, no. 3, p. 298-312, https:// doi.org/10.3398/064.076.0307.

Renne, R.R., Bradford, J.B., Burke, I.C., and Lauenroth, W.K., 2019, Soil texture and precipitation seasonality influence plant community structure in North American temperate shrub steppe: Ecology, v. 100, no. 11, article e02824, https://doi. org/10.1002/ecy.2824.

Renne, R.R., Schlaepfer, D.R., Palmquist, K.A., Bradford, J.B., Burke, I.C., and Lauenroth, W.K., 2019, Soil and stand structure explain shrub mortality patterns following global change-type drought and extreme precipitation: Ecology, v. 100, no 12, article e02889, https://doi.org/10.1002/ecy.2889. 


\section{Encyclopedia of the World's Biomes-Sagebrush Steppe and Shrubland}

A USGS scientist authored a chapter of the Encyclopedia of the World's Biomes titled "North American Sagebrush Steppe and Shrubland," that documents the unique characteristics of the sagebrush biome. The USGS joined other scientists and biogeographers around the world to describe Earth's biomes - large areas with distinct terrestrial and aquatic features, natural communities, characteristic climates, and natural processes. The encyclopedia is an up-to-date, comprehensive source of information on biodiversity importance, anthropogenic stressors, effects of changing climate, and conservation strategies around the world. The encyclopedia has been published online in the reference collection of Earth Systems and Environmental Sciences.

\section{Contact}

Douglas J. Shinneman, USGS Forest and Rangeland Ecosystem Science Center; dshinneman@usgs.gov; 208-426-5206

\section{Publication}

Shinneman, D.J., 2020, North American sagebrush steppe and shrubland, in M.I. Goldstein and D.A. DellaSala, eds., Encyclopedia of the world's biomes: Amsterdam, Netherlands, Elsevier, p. 505-515, https://doi.org/10.1016/ B978-0-12-409548-9.11982-7.

\section{Defining Multi-Scaled Functional Landscape Connectivity for the Sagebrush Biome to Support Management and Conservation Planning of Multiple Species}

Habitat loss and fragmentation resulting from disturbances threaten the persistence of wildlife populations in the sagebrush biome, in part because they impede animal movement and diminish species' habitat and functional connectivity. To identify the areas of the sagebrush landscape that may facilitate or impede the movement of multiple key species, scientists are developing a large landscape connectivity analysis. Using a wall-to-wall approach similar to that used to produce the Omniscape model (a connectivity model prepared for the State of California), USGS and CSU scientists will model multispecies connectivity through intact and disturbed areas of the sagebrush landscape. This research can facilitate the identification of priority connections and corridors among key wildlife populations (for example, priority areas of conservation), and identify landscape restoration opportunities that could increase connectivity. These efforts will aid in the conservation and management of habitat connectivity in the sagebrush biome by providing a broad, multispecies view of landscape connectivity that can aid in future development, conservation, and restoration planning.

\section{Contacts}

Michael O’Donnell, USGS Fort Collins Science Center; odonnellm@usgs.gov; 970-226-9407

Julie A. Heinrichs, Colorado State University, in cooperation with USGS Fort Collins Science Center; jheinrichs@usgs.gov; 970-226-9149

Cameron L. Aldridge, USGS Fort Collins Science Center; aldridgec@usgs.gov; 970-226-9433 


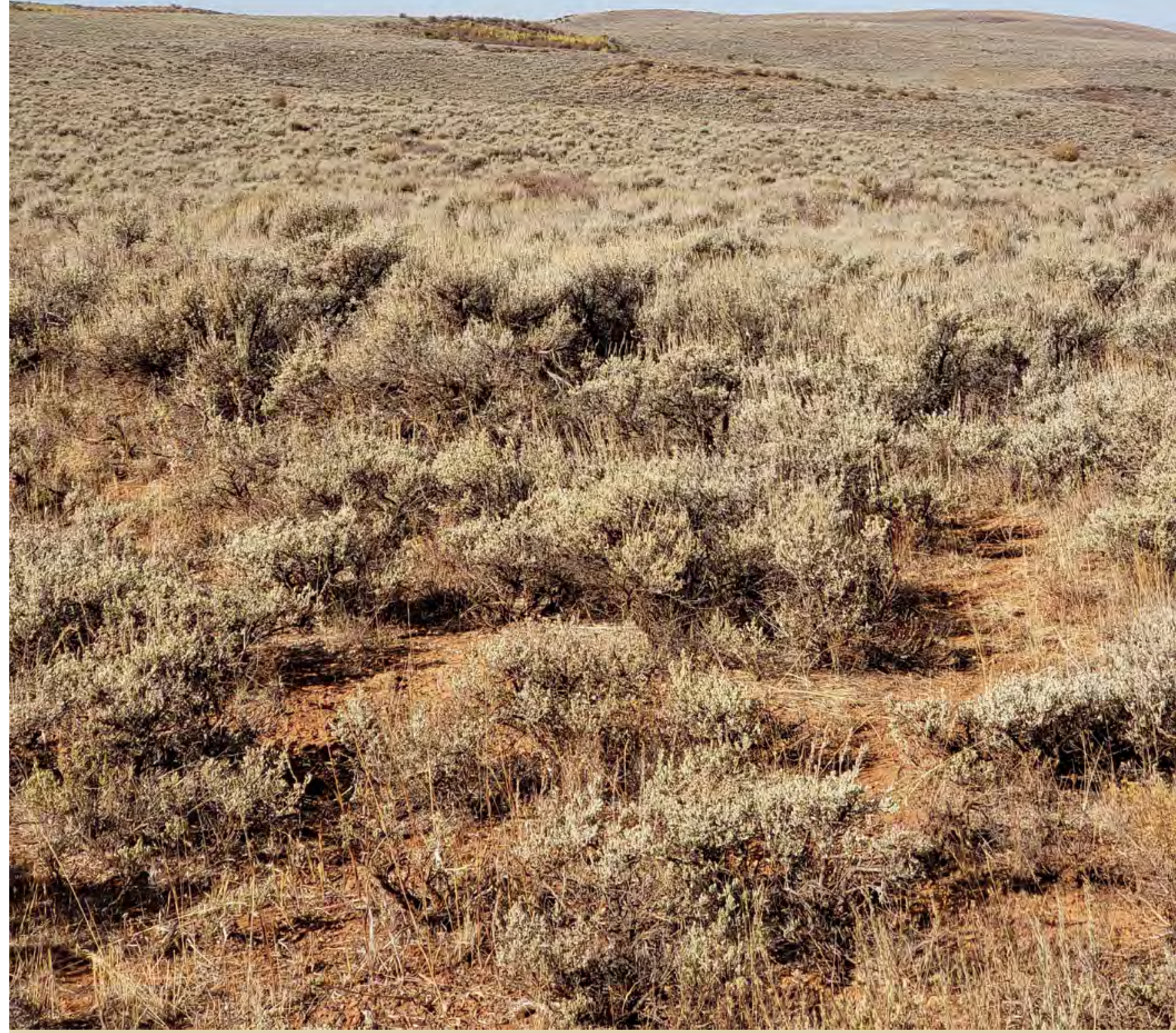

Sagebrush in northeastern Utah. Photograph by Steven Hanser, U.S. Geological Survey. 


\section{Building the Sage-Grouse Umbrella with Songbird Habitat Models}

Given the diverse habitat types used for their life history in the sagebrush biome, greater sage-grouse are often proposed as an umbrella species for communities of other sagebrush-obligate species. Data gaps remain throughout the sage-grouse range, however, including in northeastern Wyoming. Concurrently, an ambitious effort is underway to monitor bird communities across the West following the IMBCR program, and the distribution of these species can be characterized by specific habitat components that overlap sage-grouse seasonal habitats. USGS and CSU scientists are using IMBCR data and hierarchical community models to create predictive surfaces of bird use by habitat type and comparing these predictions to habitat prioritization derived from sage-grouse locations. With the extent of IMBCR sampling across the West (nine states that overlap sage-grouse range), this approach has the potential to be extended to other areas with low-density sage-grouse populations where direct identification of seasonal habitats is difficult.

\section{Contacts}

Adrian P. Monroe, USGS Fort Collins Science Center; amonroe@usgs.gov; 970-226-9122

Cameron L. Aldridge, USGS Fort Collins Science Center; aldridgec@usgs.gov; 970-226-9433

\section{Modeling Habitat and Assessing Threats for Lizards and Snakes in Sagebrush Ecosystems}

There is a need to identify how greater sage-grouse habitat management, including alteration of sagebrush shrublands and pinyon-juniper woodlands, may influence lizards and snakes. Researchers are mapping and modeling the distribution and habitat associations of lizards and snakes in sagebrush ecosystems. They are examining their response to changes in habitat resulting from greater sage-grouse restoration, shifts in vegetation as a result of fire and invasive annual grasses, and regional changes in temperature and precipitation. A map of priority areas for conservation of lizards and snakes in sagebrush ecosystems that also identifies the relative importance of public and private lands will also be produced. This work provides baseline information about habitat needs and identification of priority areas for conservation for lizards and snakes in sagebrush ecosystems.

\section{Contact}

David S. Pilliod, USGS Forest and Rangeland Ecosystem Science Center; dpilliod@usgs.gov; 208-426-5202

\section{Publications}

Jeffries, M.I., 2019, Reptile richness in the range of the sage-grouse, derived from species range maps: U.S. Geological Survey data release, https://doi.org/10.5066/P9XWALSI.

Pilliod, D.S., Jeffries, M.I., Arkle, R.S., and Olson, D.H., 2020, Reptiles under the conservation umbrella of the Greater sagegrouse: The Journal of Wildlife Management, v. 84, no. 3, p. 478-491, https://doi.org/10.1002/jwmg.21821. 


\section{Mapping Projected Soil Temperature and Moisture Regimes in a Changing Climate}

The current understanding of resistance of sagebrush ecosystems to invasion by exotic annual grasses and resilience to disturbance has led to maps of vulnerability using estimates of soil temperature and moisture conditions. USGS scientists are projecting those soil temperature and moisture conditions into the future to understand the potential implications of altered precipitation and temperature on sagebrush ecosystems. This project includes three tasks: (1) simulating soil moisture and soil temperature patterns under current conditions across the range of sagebrush (at approximately 10-kilometer resolution), (2) relating those simulations to the distribution of resistance and resilience classes to characterize simulated conditions within each class, and (3) simulating future soil moisture and temperature patterns under a suite of future scenarios to determine how the location of resistance and resilience classes shift in the middle and end of the 21 st century.

\section{Contact}

John B. Bradford, USGS Southwest Biological Science Center; jbradford@usgs.gov; 928-556-7300

\section{Publication}

Bradford J.B., Schlaepfer, D.R., Lauenroth, W.K., Palmquist, K.A., Chambers, J.C., Maestas, J.D., Campbell, S.B., 2019, Climate-driven shifts in soil temperature and moisture regimes suggest opportunities to enhance assessments of dryland resilience and resistance: Frontiers in Ecology and Evolution, v. 7, article 358, September, https://doi.org/10.3389/ fevo.2019.00358.

\section{Soil-Climate Modeling to Improve Understanding of Pattern and Processes in Sagebrush Ecosystems-A Spatially Explicit Soil Classification}

Resistance and resilience concepts provide an essential framework for sagebrush habitat management. Previously existing resistance and resilience spatial data reflected temporally static NRCS soil data. USGS scientists are using new high-resolution data on soils, climate, solar radiation, and daily snowmelt to develop approximately 13 continuous and dynamic estimates of seasonal moisture balances and soil temperature and moisture regime classifications. Enhancements will account for temporal lags of water release, modified temperature, seasonal moisture budgets, and refinements of moisture-temperature regimes. These results will help provide enhanced understanding of historic and future conditions that may influence the distribution of invasive plants and invasion risk, the distribution and dynamics of sagebrush, and recovery rates. Model and data development have been completed in the initial pilot project area in southwestern Wyoming, and this effort is now being expanded across the entire sagebrush biome.

\section{Contacts}

Daniel J. Manier, USGS Fort Collins Science Center; manierd@usgs.gov; 970-226-9466

Michael O’Donnell, USGS Fort Collins Science Center; odonnellm@usgs.gov; 970-226-9407

\section{Assessing Ecological Drought Risk in Restoration of Burned Sagebrush Steppe}

The sagebrush ecosystem is one of the largest plant communities in North America, and it is rapidly being lost to wildfires. Postfire management strategies, such as seedings and plantings, herbicide applications, and grazing, represent one of the most significant conservation investments into western landscapes. USGS researchers are studying how ecological drought affects seeding or planting outcomes across a range of climate, topographic, and soil conditions. Using field and remote sensing data from historic postfire sagebrush seedings or plantings and weather information, the scientists are quantifying ecological drought in terms of how much less precipitation must be before vegetation recovery is affected. Results will be used to create a drought risk assessment module for the USGS Land Treatment Exploration Tool (described above). Additionally, a model will be developed to simulate the benefits of repeated seedings or plantings or those that are timed to hedge against drought. Results can assist managers during the treatment planning phase to evaluate potential drought impacts over current one-off postfire management practices. These outcomes will be important steps towards justifying and enabling adaptive management of burned areas. 


\section{Contact}

Matthew J. Germino, USGS Forest and Rangeland Ecosystem Science Center; mgermino@usgs.gov; 208-426-3353

\section{Publications}

O'Connor, R.C., Germino, M.J., Barnard, D.M., Andrews, C.M., Bradford, J.B., Pilliod, D.S., Arkle, R.S., and Shriver, R.K., 2020, Small-scale water deficits after wildfires create long-lasting ecological impacts: Environmental Research Letters, v. 15, no. 4, article 044001, https://doi.org/10.1088/1748-9326/ab79e4.

O’Connor, R.C., Germino, M.J., Barnard, D.M., Andrews, C.M., Bradford, J.B., Pilliod, D.S., Arkle, R.S., and Shriver, R.K., 2020, Ecological drought for sagebrush seedings in the Great Basin: U.S. Geological Survey data release, https://doi.org/10.5066/P9LDKQE2.

\section{Assessing Vulnerability to Drought in Dryland Ecosystems of the Western United States}

Managers of public lands in the Western United States face enormous challenges under recent warmer, drier conditions that are expected to worsen with climate change. This enhanced aridity can lead to permanent degradation of wildlife habitat and ecological services upon which humans depend. To help managers confront these challenges and inform possible future management scenarios meant to address altered temperature and precipitation regimes, USGS scientists have initiated a project that integrates plot- and remote sensing-based vegetation monitoring data collected by management agencies in the Western United States with climate and soil water conditions to determine which types of habitat are vulnerable to drought and climate change, what habitat changes may occur, and where across the landscape these changes will be most pronounced.

\section{Contact}

Seth M. Munson, USGS Southwest Biological Science Center; smunson@usgs.gov; 928-556-7301

\section{Publication}

Gremer, J.R., Andrews, C., Norris, J.R., Thomas, L.P., Munson, S.M., Duniway, M.C., and Bradford, J.B., 2018, Increasing temperature seasonality may overwhelm shifts in soil moisture to favor shrub over grass dominance in Colorado Plateau drylands: Oecologia, v. 188, no. 4, p. 1195-1207, https://doi.org/10.1007/s00442-018-4282-4.

\section{A Climate Vulnerability Assessment Framework for Data-Poor Species}

Assessing vulnerability to climate change is a key step in anticipating climate impacts on species. A full assessment of vulnerability involves three essential components - sensitivity, adaptive capacity, and exposure. For poorly studied species, assessing sensitivity and adaptive capacity can be extremely challenging. USGS, CSU, and University of Washington scientists are developing an approach to assess both of these components of vulnerability for poorly studied species that builds on existing sensitivity, vulnerability, and adaptive capacity assessment tools and datasets. This new approach for identifying climate-vulnerable species will improve management strategies and help avoid surprising negative consequences for under-studied species; it will also help prioritize species in need of research, protection, and management.

\section{Contacts}

Julie A. Heinrichs, Colorado State University, in cooperation with USGS Fort Collins Science Center; jheinrichs@usgs.gov; 970-226-9149

Steven E. Hanser, USGS Fort Collins Science Center; shanser@usgs.gov; 970-226-9309 


\section{Assessing the Future of Sagebrush Ecosystems with Changing Precipitation and Temperature}

Sagebrush directly acquires water from the soil, and patterns of available soil moisture that are altered by changes in precipitation and temperature may influence the health and distribution of sagebrush ecosystems. This project characterizes the ecohydrological conditions that support sagebrush ecosystems, identifies how those conditions could change in the future, and assesses the rangewide potential impacts for sage-grouse habitat. In collaboration with university scientists, USGS scientists are (1) quantifying how changes in precipitation and temperature may affect areas suitable to support sagebrush, (2) understanding the controls over sagebrush regeneration (a key limiting life stage for sagebrush), (3) describing uncertainty in species distribution models, and (4) improving the quality and usability of models that identify future suitable sagebrush extent. Outcomes of the project can help inform the development of potential climate adaptation strategies.

\section{Contact}

John B. Bradford, USGS Southwest Biological Science Center; jbradford@usgs.gov; 928-556-7300

\section{Publications}

Palmquist, K.A., Bradford, J.B., Martyn, T.E., Schlaepfer, D.R., and Lauenroth, W.K., 2018, STEPWAT2-An individual-based model for exploring the impact of climate and disturbance on dryland plant communities: Ecosphere, v. 9, no. 8 , article e02394, https://doi.org/10.1002/

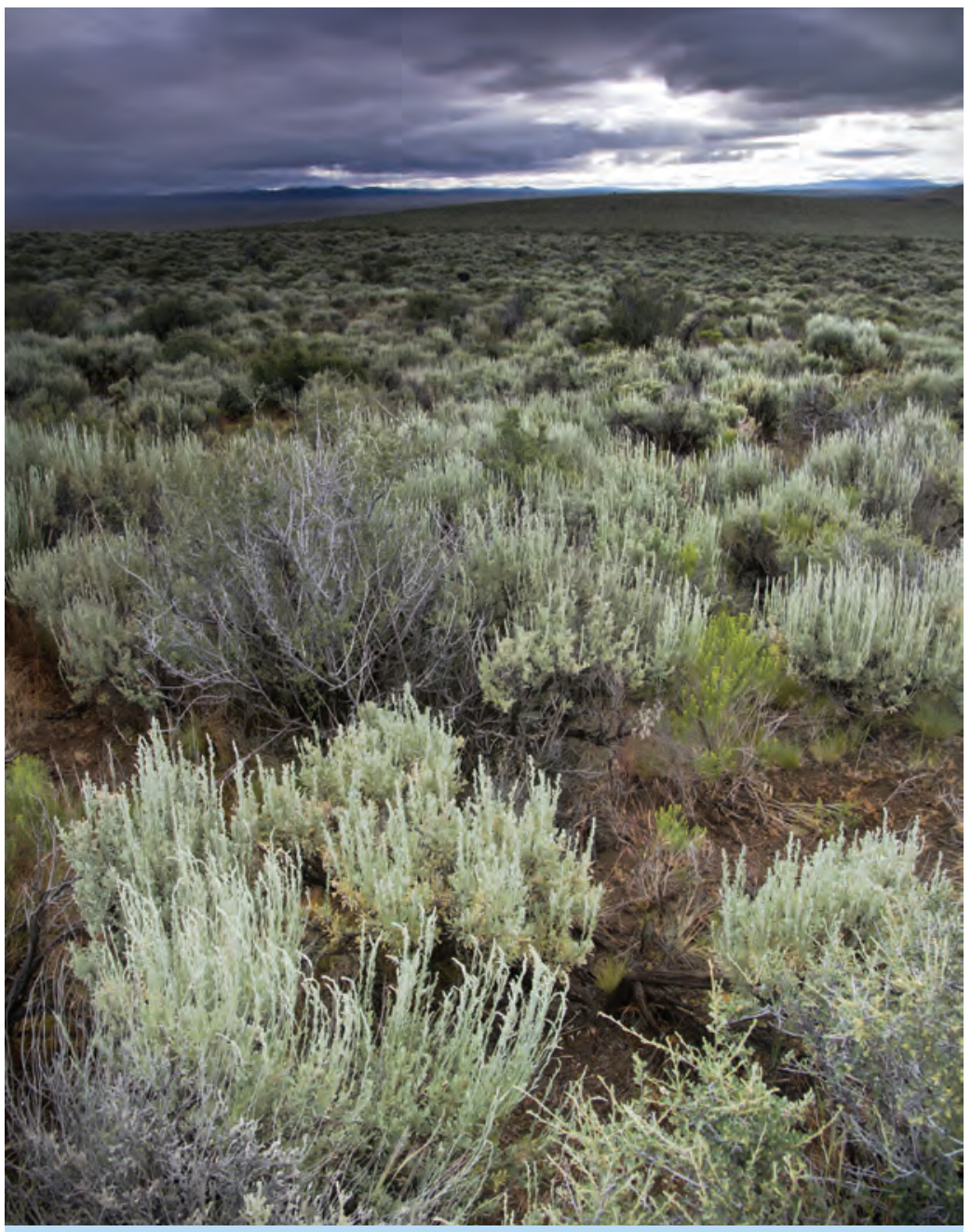

Sagebrush. Photograph by Conservation Media, used with permission. ecs2.2394.

Palmquist, K.A., Schlaepfer, D.R., Bradford, J.B., and Lauenroth, W.K., 2016a, Mid-latitude shrub steppe plant communitiesClimate change consequences for soil water resources: Ecology, v. 97, no. 9, p. 2342-2354, https://doi.org/10.1002/ecy.1457.

Palmquist, K.A., Schlaepfer, D.R., Bradford, J.B., and Lauenroth, W.K., 2016b, Spatial and ecological variation in dryland ecohydrological responses to climate change-Implications for management: Ecosphere, v. 7, no. 11, article e01590, 20 p., https://doi.org/10.1002/ecs2.1590.

Schlaepfer, D.R., Lauenroth, W.K., and Bradford, J.B., 2014a, Modeling regeneration responses of big sagebrush (Artemisia tridentata) to abiotic conditions: Ecological Modelling, v. 286, August 24, p. 66-77, https://doi.org/10.1016/j.ecolmodel.2014.04.021.

Schlaepfer, D.R., Lauenroth, W.K., and Bradford, J.B., 2014b, Natural regeneration processes in big sagebrush (Artemisia tridentata): Rangeland Ecology \& Management, v. 67, no. 4, p. 344-357, https://doi.org/10.2111/REM-D-13-00079.1.

Schlaepfer, D.R., Taylor, K.A., Pennington, V.E., Nelson, K.N., Martyn, T.E., Rottler, C.M., Lauenroth, W.K., and Bradford, J.B., 2015, Simulated big sagebrush regeneration supports predicted changes at the trailing and leading edges of distribution shifts: Ecosphere, v. 6, no. 1, p. 1-31, https://doi.org/10.1890/ES14-00208.1.

Wilson, S.D., Schlaepfer, D.R., Bradford, J.B., Lauenroth, W.K., Duniway, M.C., Hall, S.A., Jamiyansharav, K., Jia, G., Lkhagva, A., Munson, S.M., Pyke, D.A., and Tietjen, B., 2018, Functional group, biomass, and climate change effects on ecological drought in semiarid grasslands: Journal of Geophysical Research Biogeosciences, v. 123, no. 3, p. 1072-1085, https://doi.org/10.1002/2017JG004173. 


\section{Forecasting the Spatiotemporal Dynamics of Sagebrush in Wyoming Under a Changing Climate}

Prioritizing landscapes for sage-grouse habitat conservation is complicated by long-term changes in climate. Will the habitat we conserve today remain viable for sage-grouse and other sagebrush-obligate species in the future? To answer this question, USGS scientists and partners are developing a dynamic statistical model capable of forecasting sagebrush cover over space and time. They are using a spatially explicit, 28-year time series of sagebrush cover in southwestern Wyoming to model past responses of sagebrush to interannual variation in weather and to forecast future sagebrush cover under projected climate change. Climate change projections from an ensemble of global circulation models are being used for forecasts. The results of this work will produce maps of sagebrush cover from 1985 (past) to 2050 (future) for the core areas of the south-central local working group area, increasing our fundamental understanding of how sagebrush in Wyoming responds to short-term weather fluctuations and long-term climatic changes.

\section{Contact}

Cameron L. Aldridge, USGS Fort Collins Science Center; aldridgec@usgs.gov; 970-226-9433

\section{Weather-Centric Rangeland Revegetation Planning}

Rehabilitation and restoration of rangelands impacted by invasions of annual weeds are challenging because climate and weather variability affects seed germination, survival and establishment of seedlings, annual weed dynamics, wildfire frequency, and soil stability. In this collaboration, the USDA Agricultural Research Service, USGS, and university partners are developing tools to inform revegetation efforts using site-specific weather information from historical observations, seasonal climate forecasts, and climate-change projections. Incorporating climate and weather information into rangeland revegetation planning could reduce management uncertainty, improve understanding of the ecological processes

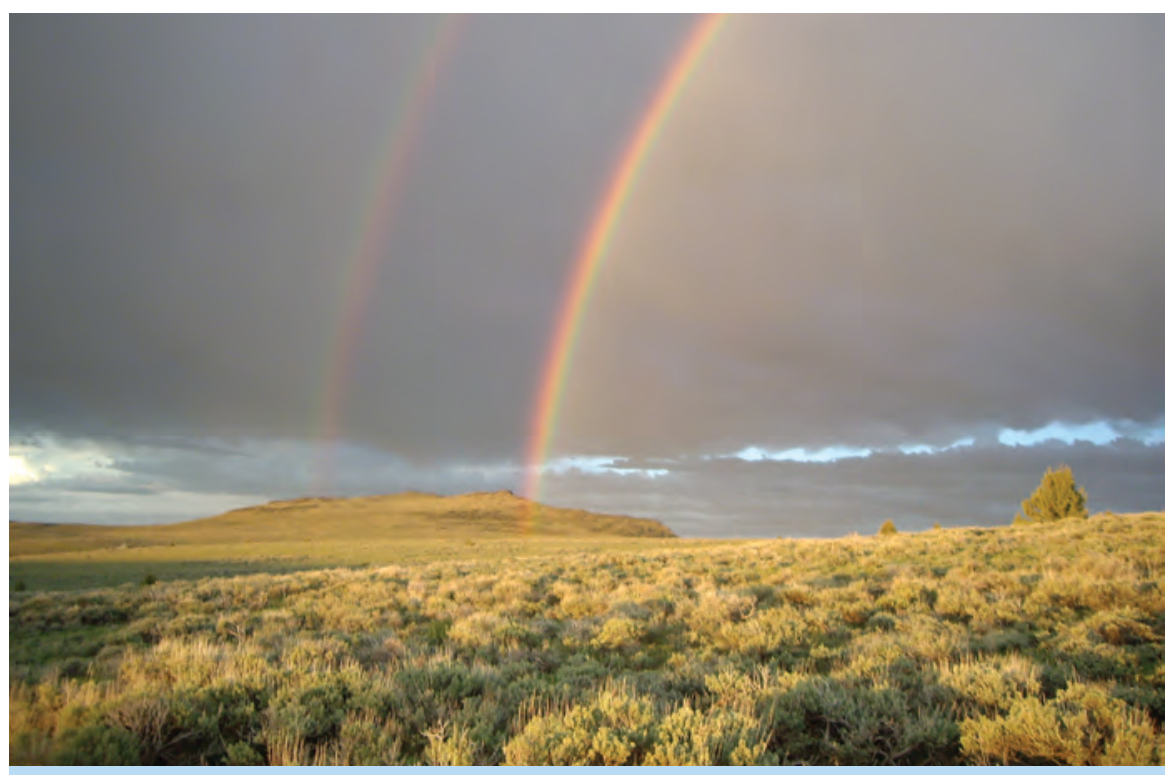

Rainbow on Steens Mountain in southeastern Oregon. Photograph by Steven Hanser, U.S. Geological Survey. driving succession, and increase the effi-

ciency of rehabilitation and restoration efforts. Seasonal climate forecasts and climate-change projections could improve the cost efficiency of management treatments and help managers develop mitigation and adaptation strategies for long-term practices.

\section{Contacts}

Matthew J. Germino, USGS Forest and Rangeland Ecosystem Science Center; mgermino@usgs.gov; 208-426-3353

David S. Pilliod, USGS Forest and Rangeland Ecosystem Science Center; dpilliod@usgs.gov; 208-426-5202

\section{Publication}

Hardegree, S.P., Abatzoglou, J.T., Brunson, M.W., Germino, M.J., Hegewisch, K.C., Moffet, C.A., Pilliod, D.S., Roundy, B.A., Boehm, A.R., and Meredith, G.R., 2018, Weather-centric rangeland revegetation planning: Rangeland Ecology \& Management, v. 71, no. 1, p. 1-11, https://doi.org/10.1016/j.rama.2017.07.003. 


\section{Response of Sagebrush Ecosystems to Precipitation Shifts}

Rangelands store approximately 30 percent of the world's terrestrial carbon, yet it is unclear how changes in precipitation associated with changing climate will influence carbon storage capacity in these dry ecosystems. To investigate how rangelands will respond to altered precipitation patterns, USGS and university researchers have been investigating how changes in the amount and timing of precipitation affect litter decomposition and soil carbon stabilization in plots that received supplemental precipitation in either winter or summer. These experiments were conducted over a 21 -year period in plots dominated by native sagebrush and crested wheatgrass (Agropyron cristatum), an introduced species that has become invasive. Results may inform predictions of how carbon storage in rangeland communities will be affected by the interaction of altered precipitation and conversion of diverse native communities to exotic grasslands.

\section{Contact}

Matthew J. Germino, USGS Forest and Rangeland Ecosystem Science Center; mgermino@usgs.gov; 208-426-3353

\section{Publications}

Campos, X., Germino, M.J., and de Graaff, M.-A., 2017, Enhanced precipitation promotes decomposition and soil C stabilization in semiarid ecosystems, but seasonal timing of wetting matters: Plant and Soil, v. 416, nos. 1-2, p. 427-436, https://doi.org/10.1007/s11104-017-3221-1.

Germino M.J., and Reinhart K., 2014, Desert shrub responses to experimental modification of precipitation seasonality and soil depth-Relationship to the two-layer hypothesis and ecohydrological niche: Journal of Ecology, v. 102, no. 4, p. 989-997, https://doi.org/10.1111/1365-2745.12266.

Huber, D.P., Lohse, K.A., Commendador, A., Joy, S., Aho, K., Finney, B., and Germino, M.J., 2019, Vegetation and precipitation shifts interact to alter organic and inorganic carbon storage in cold desert soils: Ecosphere, v. 10, no. 3, article e02655, 17 p., https://doi.org/10.1002/ecs2.2655.

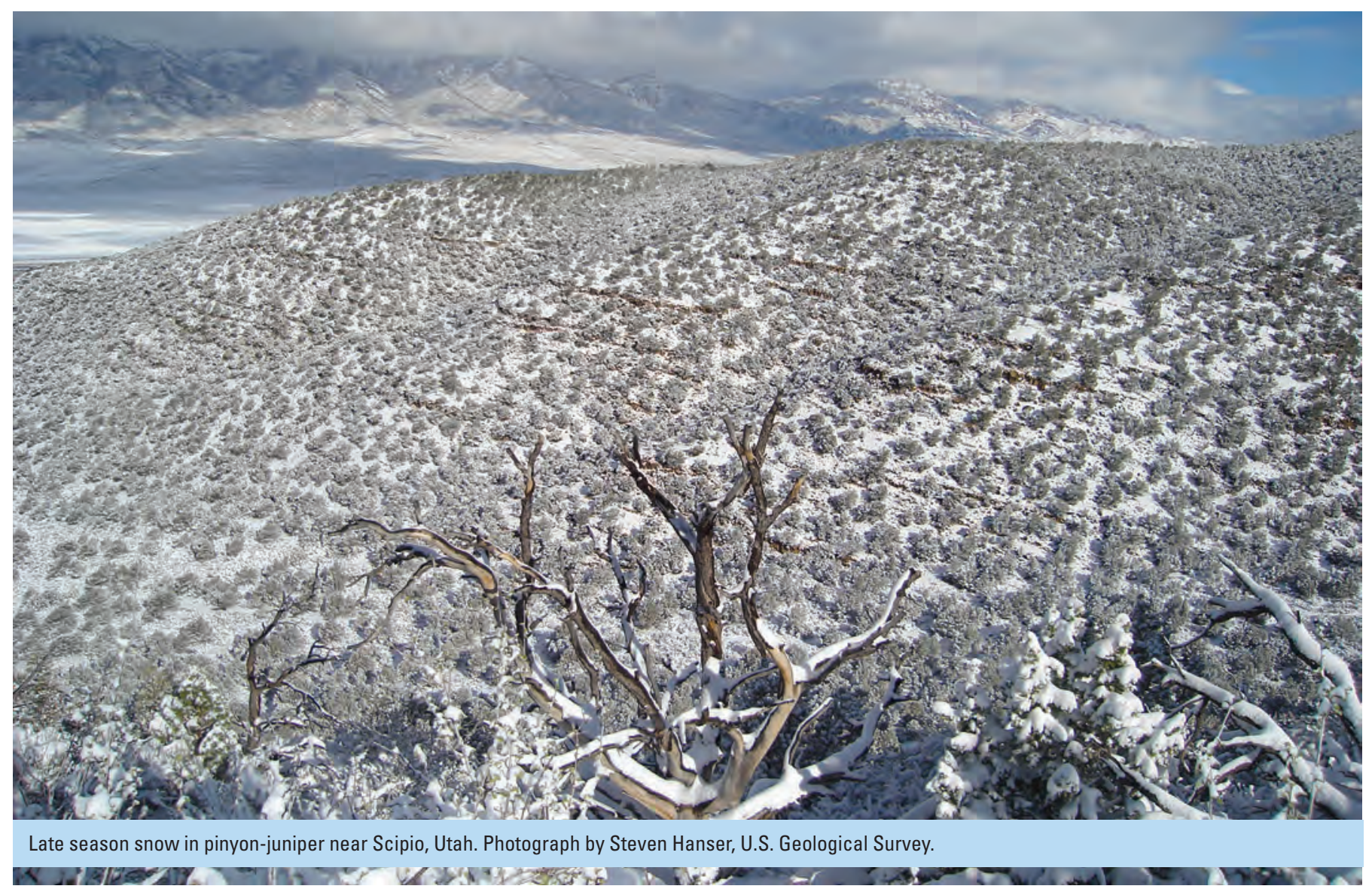


McAbee, K., Reinhardt, K., Germino, M.J., and Bosworth, A., 2017, Response of aboveground carbon balance to long-term, experimental enhancements in precipitation seasonality is contingent on plant community type in cold-desert rangelands: Oecologia, v. 183, no. 3, p. 861-874, https://doi.org/10.1007/s00442-017-3814-7.

Reinhardt, K., McAbee, K., and Germino, M.J., 2019, Changes in structure and physiological functioning due to experimentally enhanced precipitation seasonality in a widespread shrub species: Plant Ecology, v. 220, no. 2, p. 199-211, https://doi.org/10.1007/s11258-018-0845-z.

\section{Surface Energy Fluxes and Balance Components, Soil Moisture, and Evapotranspiration in a Semi- Arid Environment}

USGS scientists and colleagues investigated the influence of rainfall, soil, vegetation, and topography on water and energy balance in sagebrush, cheatgrass, and lodgepole pine (Pinus contorta) sites in Southern Idaho. The broader implications of this study suggest that sagebrush ecosystem regions may serve as potential recharge zones for enhancing groundwater storage in the Snake River Plain as they exhibit lower evapotranspiration rates compared with other ecosystems. They also examined surface fluxes of energy and moisture for sagebrush, cheatgrass, and lodgepole pine in Idaho by pooling data on biophysical processes that control surface energy partitioning. Results indicate that sagebrush, cheatgrass, and lodgepole pine ecosystems in the Snake River Basin exhibit distinct surface energy partitioning because of heterogeneity in available energy, soil moisture conditions, and vegetation characteristics.

\section{Contact}

Matthew J. Germino, USGS Forest and Rangeland Ecosystem Science Center; mgermino@usgs.gov; 208-426-3353

\section{Publications}

Sridhar, V., Billah, M.M., Valayamkunnath, P., Zhao, W., Allen, R.G., and Germino, M.J., 2019, Field-scale intercomparison analysis of ecosystems in partitioning surface energy balance components in a semi-arid environment: Ecohydrology \& Hydrobiology, v. 19, no. 1, p. 24-37, https://doi.org/10.1016/j.ecohyd.2018.06.005. [A corrigendum to correct the omission of authors and acknowledgements to this article was posted in January 2020 at https://doi.org/10.1016/j.ecohyd.2019.08.001.]

Valayamkunnath, P., Sridhar, V., Zhao, W., Allen, R.G., and Germino, M.J., 2018, Intercomparison of surface energy fluxes, soil moisture, and evapotranspiration from eddy covariance, large-aperture scintillometer, and modeling across three ecosystems in a semiarid climate: Agricultural and Forest Meteorology, v. 248, p. 22-47, https://doi.org/10.1016/j.agrformet.2017.08.025. [A corrigendum to correct the omission of an author, funding sources, and key support staff for this article was posted on November 15, 2019, at https://doi.org/10.1016/j.agrformet.2019.107646.]

Valayamkunnath, P., Sridhar, V., Zhao, W. Allen, R.G., and Germino, M.J., 2019, A comprehensive analysis of interseasonal and interannual energy and water balance dynamics in semiarid shrubland and forest ecosystems: Science of the Total Environment, v. 651, pt. 1, p. 381-398, https://doi.org/10.1016/j.scitotenv.2018.09.130. [A corrigendum to correct the omission of an author, funding sources, and key support staff for this article was posted on November 15, 2019, at https://doi.org/10.1016/j.agrformet.2019.107646.]

\section{Phenological Responses to Environmental Drivers in the Northern Great Plains}

Ecological response of vegetation within a growing season is influenced by the broader spatial and temporal context; therefore, contextual analyses are needed to understand yearly responses and variability within the growing season. To inform rangeland monitoring efforts on BLM-managed lands across Montana, North Dakota, and South Dakota, USGS scientists are working with the BLM, Montana State University, and the Montana Climate Office to examine factors influencing the variability of phenology. Specific objectives include (1) examine phenology trends in relation to climate patterns; (2) compare climate drivers of productivity, including temperature, precipitation, and vapor pressure deficit; (3) improve the understanding of ecological memory in the response of phenological measures to climate drivers; (4) examine relationships between phenology and soil moisture, weather, and land context; (5) develop and use new approaches for tracking fine-scale differences in phenology and scaling relationships between in situ and satellite measurements; and (6) use these processes to develop models of productivity and ecological site potential based on climate and management scenarios. An understanding of these feedbacks and 
mechanisms can improve the assessment of management practices, such as restoration, treatment, timing adjustments, and other actions employed to meet natural resource objectives.

\section{Contact}

David J.A. Wood, USGS Northern Rocky Mountain Science Center; dwood@usgs.gov; 406-896-5246

\section{Tracking Drought-Induced Variability in Sagebrush Ecosystem Productivity}

USGS scientists, in collaboration with Wyoming Landscape Conservation Initiative partners, are investigating the recovery of sagebrush ecosystems after a recent, severe drought in the Upper Green River Basin, Wyoming. The scientists are using satellite data to characterize broad characteristics of growing season productivity and detect monthly anomalies associated with drought from a 17-year period (2000-16). They are investigating the timing and lags of seasonal temperature and moisture on vegetation condition and determining if reduction in productivity is mediated by local biophysical properties. Map products will identify the extent and severity of the disturbance and highlight areas for plant community assessment. This approach can be used to assess the status and trends of sagebrush ecosystems over broad spatial and temporal scales and assess the recovery of sagebrush ecosystems exposed to multiple stressors and disturbances such as drought, energy development, and management treatment.

\section{Contact}

Patrick Anderson, USGS Fort Collins Science Center; andersonpj@usgs.gov; 970-226-9488

\section{Publication}

Assal, T.J., 2018, Standardized precipitation evaporation index for the Upper Green River Basin (1896-2017): U.S. Geological Survey data release, https://doi.org/10.5066/P9VLM7Z6.

\section{Sagebrush Ecosystem Research Funded by Climate Adaptation Science Centers}

The USGS manages the network of Climate Adaptation Science Centers that provide funding for several of the USGS-led projects listed in this document, as well as supporting research by external partners (universities, nongovernmental organizations, and so forth). Research funding provided to external partners is helping address a variety of climate-related science needs with a focus on those identified in the "Integrated Rangeland Fire Management Strategy Actionable Science Plan" and related management-oriented science needs assessments. The North Central, Northwest, and Southwest Climate Adaptation Science Centers have and will continue to provide resources for supporting activities identified as high-priority needs by the major management entities. Additional information can be found at https://casc.usgs.gov/.

\section{Contacts}

Nicole DeCrappeo, USGS Northwest Climate Adaptation Science Center; ndecrappeo@usgs.gov; 541-750-1021

Aparna Bamzai-Dodson, USGS North Central Climate Adaptation Science Center; abamzai@usgs.gov; 970-889-1231

Stephen T. Jackson, USGS Southwest Climate Adaptation Science Center; stjackson@usgs.gov; 520-670-5591 


\section{References Cited}

Chambers, J.C., Beck, J.L., Bradford, J.B., Bybee, J., Campbell, S., Carlson, J., Christiansen, T.J., Clause, K.J., Collins, G., Crist, M.R., Dinkins, J.B., Doherty, K.E., Edwards, F., Espinosa, S., Griffin, K.A., Griffin, P., Haas, J.R., Hanser, S.E., Havlina, D.W., Henke, K.F., Hennig, J.D., Joyce, L.A., Kilkenny, F.M., Kulpa, S.M., Kurth, L.L., Maestas, J.D., Manning, M., Mayer, K.E., Mealor, B.A., McCarthy, C., Pellant, M., Perea, M.A., Prentice, K.L., Pyke, D.A., Wiechman, L.A., and Wuenschel, A., 2017, Science framework for conservation and restoration of the sagebrush biome-Linking the Department of the Interior's Integrated Rangeland Fire Management Strategy to long-term strategic conservation actions; Part 1. Science basis and applications: U.S. Department of Agriculture, Forest Service, Rocky Mountain Research Station, General Technical Report RMRS-GTR-360, 213 p. [Also available at https://www.fs.usda.gov/treesearch/pubs/53983.]

Hanser, S.E., Leu, M., Knick, S.T., and Aldridge, C.L., eds., 2011, Sagebrush ecosystem conservation and managementEcoregional assessment tools and models for the Wyoming Basins: Lawrence, Kans., Allen Press, 409 p. [Also available at https://pubs.er.usgs.gov/publication/70118768.].

Integrated Rangeland Fire Management Strategy Actionable Science Plan Team, 2016, The Integrated Rangeland Fire Management Strategy actionable science plan: Washington, D.C., U.S. Department of the Interior, 128 p. [Also available at http://integratedrangelandfiremanagementstrategy.org/wp-content/uploads/2016/10/IRFMS_Actionable_Science_Plan.pdf.].

Jeffries, M.I., and Finn, S.P., 2019, The sagebrush biome range extent, as derived from classified Landsat imagery: U.S. Geological Survey data release, accessed June 14, 2020, at https://doi.org/10.5066/P950H8HS.

Jeffries, M.I., Bobo, M.R., Finn, S.P., Hanser, S.E., Remington, T., Titolo, A., Welty, J.L., and Wiechman, L.A., 2019, Sagebrush distribution within the biome range extent, as derived from classified Landsat imagery: U.S. Geological Survey data release, accessed June 14, 2020, at https://doi.org/10.5066/P9QSQPUU.

Jones, M.O., Allred, B.W., Naugle, D.E., Maestas, J.D., Donnelly, P., Metz, L.J., Karl, J., Smith, R., Bestelmeyer, B., Boyd, C., Kerby, J.D., and McIver, J.D., 2018, Innovation in rangeland monitoring-Annual, 30m, plant functional type percent cover maps for U.S. rangelands, 1984-2017: Ecosphere, v. 9, no. 9, article e02430. [Also available at https://doi.org/10.1002/ ecs2.2430.]

Knick, S.T., and Connelly, J.W., eds., 2011, Greater sage-grouse-Ecology and conservation of a landscape species and its habitats: Berkeley, University of California Press, Studies in Avian Biology, no. 38, 664 p.

Monroe, A.P., Aldridge, C.L., O’Donnell, M.S., Manier, D.J., Homer, C.G., and Anderson, P.J., 2020, Using remote sensing products to predict recovery of vegetation across space and time following energy development: Ecological Indicators, v. 110, March, article 105872. [Also available at https://doi.org/10.1016/j.ecolind.2019.105872.]

Pastick, N.J., Dahal, D., Wylie, B.K., Parajuli, S., Boyte, S.P., and Wu, Z., 2020, Characterizing land surface phenology and exotic annual grasses in dryland ecosystems using Landsat and Sentinel-2 data in harmony: Remote Sensing, v. 12, no. 4, article 725. [Also available at https://doi.org/10.3390/rs12040725.]

Rigge, M., Homer, C., Cleeves, L., Meyer, D.K., Bunde, B., Shi, H., Xian, G., Schell, S., and Bobo, M., 2020, Quantifying Western U.S. rangelands as fractional components with multi-resolution remote sensing and in situ data: Remote Sensing, v. 12, no. 3, article 412. [Also available at https://doi.org/10.3390/rs12030412.]

Schroeder M.A., Aldridge, C.L., Apa, A.D., Bohne, J.R., Braun, C.E., Bunnell, S.D., Connelly, J.W., Deibert, P.A., Gardner, S.C., Hilliard, M.A., Kobriger, G.D., McAdam, S.M., McCarthy, C.W., McCarthy, J.J., Mitchell, D.L., Rickerson, E.V., Stiver, S.J., 2004, Distribution of sage-grouse in North America: The Condor, v. 106, no. 2, p. 363-376. [Also available at https://doi.org/10.1093/condor/106.2.363.]

U.S. Fish and Wildlife Service, [2016], Sagebrush ecosystem community (rangeland fire secretarial order): U.S. Geological Survey ScienceBase web page, accessed June 14, 2020, at https://www.sciencebase.gov/catalog/item/56f58a21e4b06639d52a39d0.

Wisdom, M.J., Rowland, M.M., and Suring, L.H., eds., 2005, Habitat threats in the sagebrush ecosystem-Methods of regional assessment and applications in the Great Basin: Lawrence, Kans., Alliance Communications Group, 301 p. 


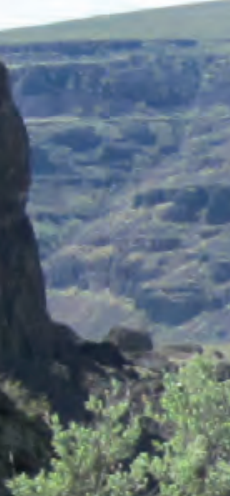

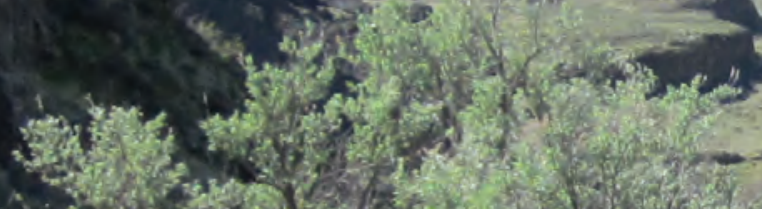

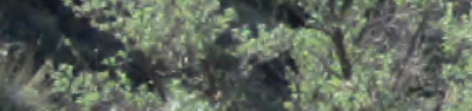

,

3

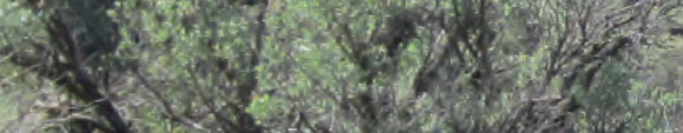

3 - 3 (2)

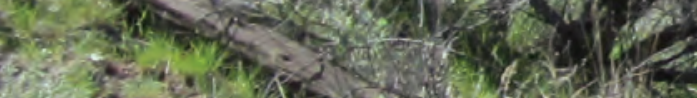

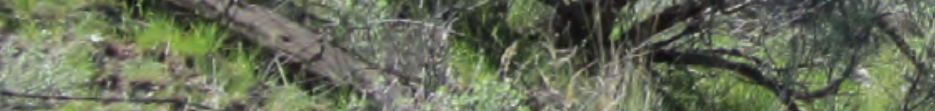

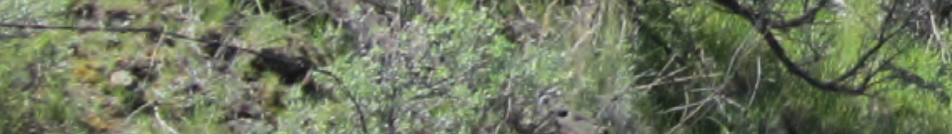

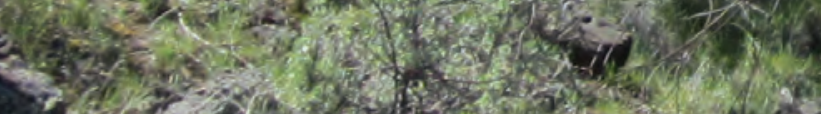

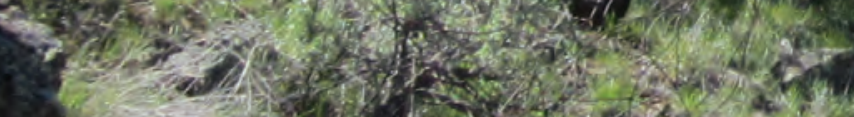

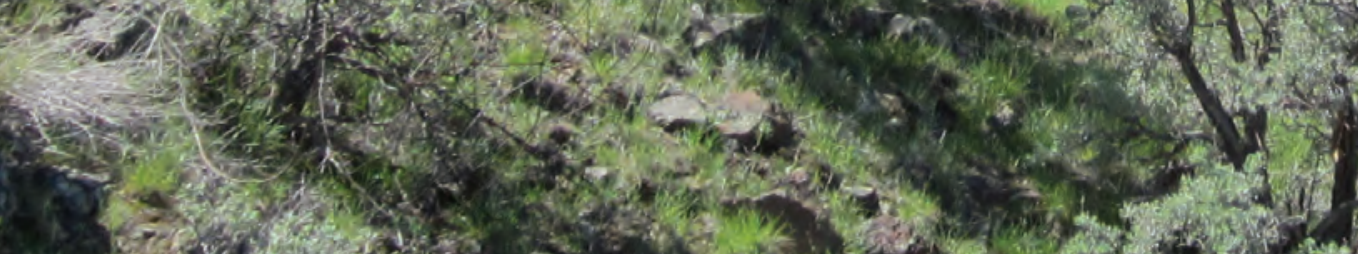

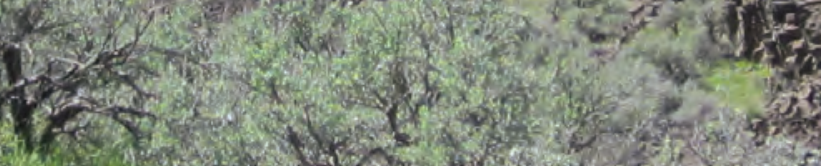

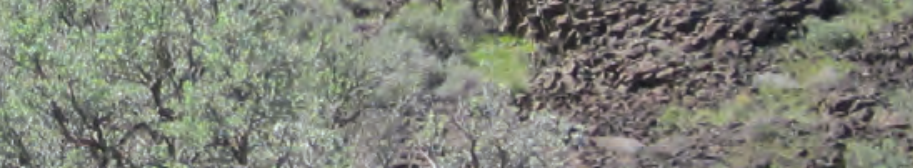
(litio 6. if

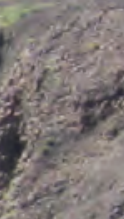

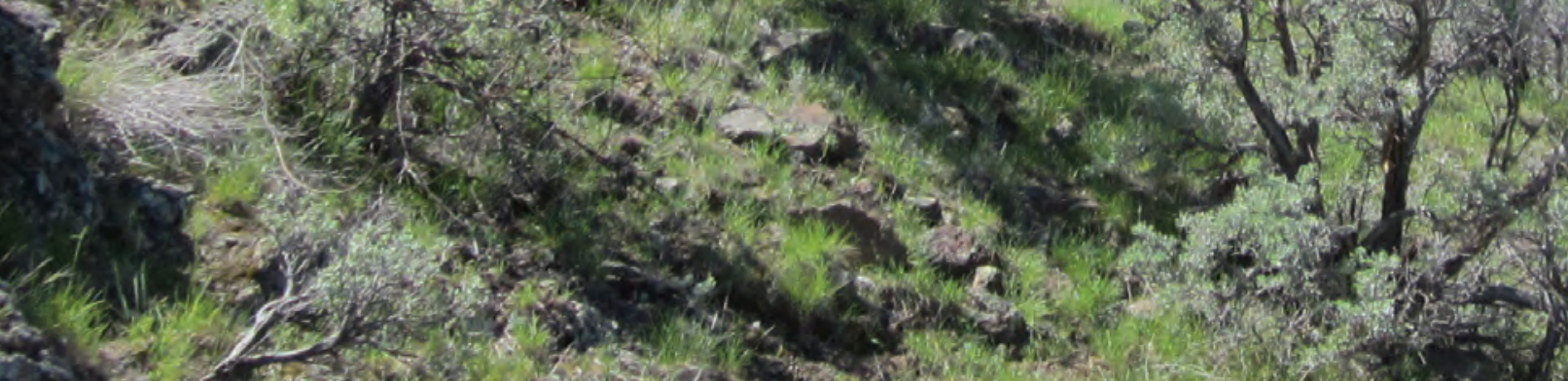

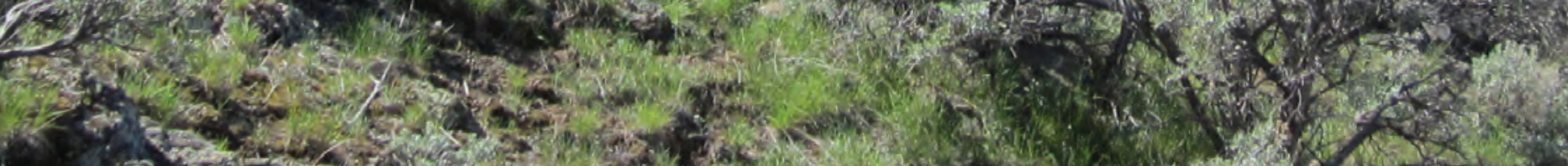

2

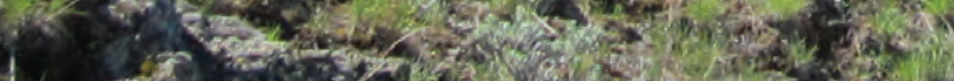


Manuscript approved for publication on August 20, 2020.

For additional information regarding this publication, please contact: Steven E. Hanser; shanser@usgs.gov

Or visit the Sage-Grouse and Sagebrush Ecosystem Program https://www.usgs.gov/ecosystems/sage-grouse-sagebrushecosystem

Prepared by the USGS Science Publishing Network Reston Publishing Service Center

Edited by J.C. Ishee

Layout by C.Y. Knutson 


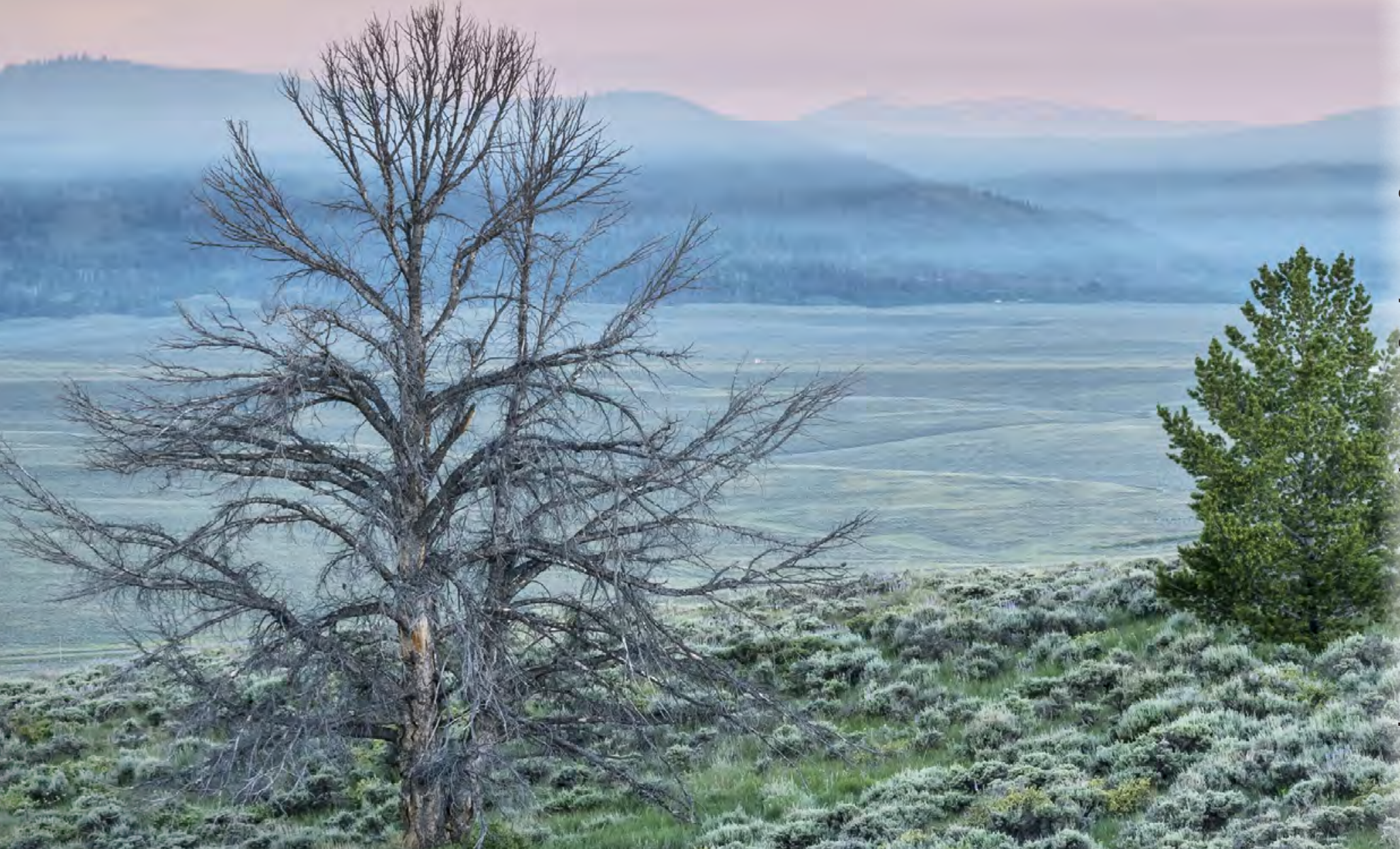

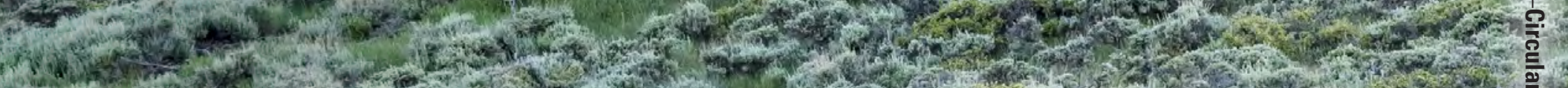

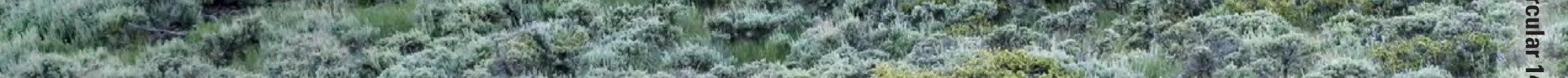

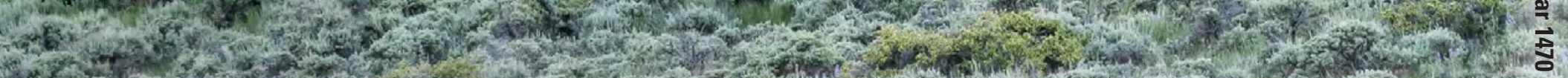

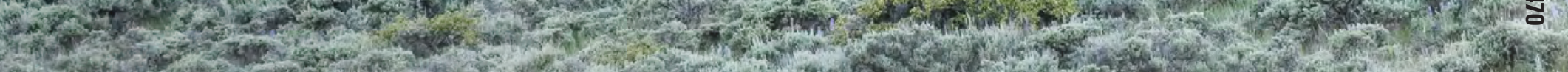

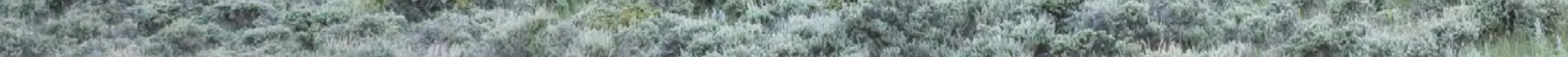

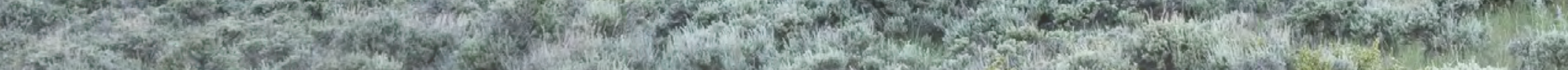

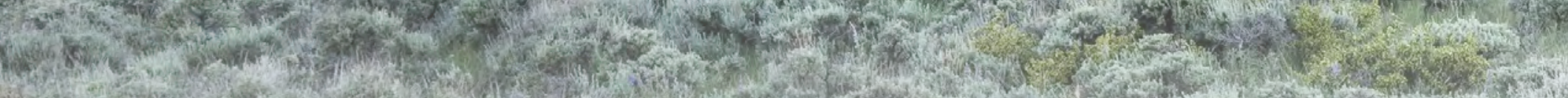

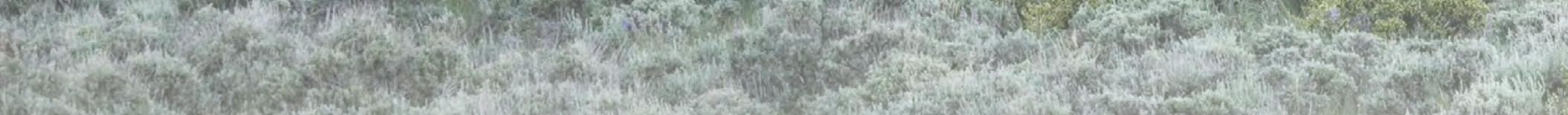

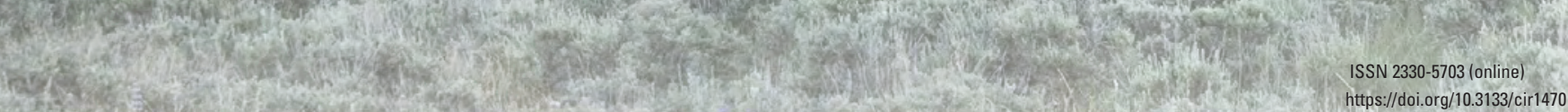

